Universidade de São Paulo

Faculdade de Filosofia, Letras e Ciências Humanas

Departamento de Letras Modernas

Programa de Pós-Graduação em Estudos Linguísticos e Literários em Inglês

Ana Paula Bianconcini Anjos

\title{
Capital financeiro e empreendedorismo: considerações sobre o sujeito contemporâneo em Match Point, de Woody Allen.
}

São Paulo

2010 
Universidade de São Paulo

Faculdade de Filosofia, Letras e Ciências Humanas

Departamento de Letras Modernas

Programa de Pós-Graduação em Estudos Linguísticos e Literários em Inglês

\section{Capital financeiro e empreendedorismo: considerações sobre o sujeito contemporâneo em Match Point, de Woody Allen.}

Ana Paula Bianconcini Anjos

Dissertação apresentada ao Programa de Pós-Graduação em Estudos Linguísticos e Literários em Inglês do Departamento de Letras Modernas da Faculdade de Filosofia, Letras e Ciências Humanas da Universidade de São Paulo, para a obtenção do título de Mestre em Letras.

Orientador: Prof. Dr. Marcos César de Paula Soares

São Paulo

2010 
Catalogação na Publicação

Serviço de Biblioteca e Documentação

Faculdade de Filosofia, Letras e Ciências Humanas da Universidade de São Paulo

Anjos, Ana Paula Bianconcini.

Capital financeiro e empreendedorismo: considerações sobre o sujeito contemporâneo em Match Point, de Woody Allen. / Ana Paula Bianconcini Anjos ; orientador: Marcos César de Paula Soares. -- São Paulo, 2010.

$203 \mathrm{f}$. : il.

Dissertação (Mestrado)--Faculdade de Filosofia, Letras e Ciências Humanas da Universidade de São Paulo.

Departamento de Letras Modernas. Área de concentração: Estudos Linguísticos e Literários em Inglês.

1. Cinema. 2. Literatura. 3. Empreendedorismo. I. Título.

II. Soares, Marcos César de Paula. 
Nome: ANJOS, Ana Paula Bianconcini

Título: Capital financeiro e empreendedorismo: considerações sobre o sujeito contemporâneo em Match Point, de Woody Allen.

Dissertação apresentada à Faculdade de Filosofia, Letras e Ciências Humanas da Universidade de São Paulo para obtenção do título de mestre em Estudos Linguísticos e Literários em Inglês

Aprovado em:

Banca Examinadora

Prof. Dr.: Instituição:

Julgamento: Assinatura:

Prof. Dr.: Instituição:

Julgamento: Assinatura:

Prof. Dr.: Instituição:

Julgamento: Assinatura: 
Para as minhas avós, a professora e a jornalista, vó Lina e vó Bebé, com amor.

À memória do Paulo. 


\section{Agradecimentos}

À Coordenação de Aperfeiçoamento de Pessoal de Nível Superior (CAPES) pela bolsa de estudos concedida de mestrado.

Ao Prof. Dr. Marcos César de Paula Soares pela orientação presente, a paciência, dedicação e confiança com que sempre discutiu este trabalho comigo.

À Prof ${ }^{a}$. Dr ${ }^{a}$. Ivone Daré Rabello e ao Prof. Dr. Ismail Xavier pela leitura atenta da pesquisa e pelas sugestões propostas no exame de qualificação. Agradeço também pela generosidade em discutirem novamente este trabalho comigo.

Aos amigos Lorena Vicini e Pedro Fragelli pela revisão e sugestões em momentos decisivos. À Lorena, em especial, pela força e o trabalho árduo nas últimas semanas, companheira das Letras e do Jornalismo.

Aos amigos "brasdegnos” Júlia Codo e Paolo Demuro pela tradução em italiano das óperas.

Aos meus pais e à minha irmã pelo carinho e apoio. Os meus pais dedicaram a vida à causa pública: são a minha inspiração.

Ao Otávio que de uma calada maneira chega sempre sorrindo como se fosse a primavera... Agradeço-o também pelas imagens desta dissertação.

Durante este trabalho, sofri alguns percalços: quebrei o pé e retirei o apêndice. E nesse momento, a assistência do Thales, da tia Márcia e do tio Kei foram fundamentais.

Aos meus familiares e amigos, agradeço um a um. Em especial, à Ciça, à Bel e à Maria.

Aos funcionários das bibliotecas e departamentos da FFLCH, ECA e FAU. 
"O que os irlandeses têm de pior é que eles se tornam corruptíveis assim que deixam de ser camponeses e viram burgueses."

Carta de Engels para Marx, 27 de Setembro de 1869. 


\section{Resumo}

O objetivo desta dissertação é compreender a configuração do sujeito contemporâneo no filme Match Point (2005), de Woody Allen. Na carreira de Allen, este filme representa o momento de uma espécie de exílio. Por problemas de financiamento nos Estados Unidos, o diretor nova-iorquino vai para a Europa. No centro do capitalismo financeiro, simbolizado pelo prédio de negócios, um irlandês alia-se à elite britânica. O protagonista reúne os valores sociais do empreendedor em um momento histórico anterior à derrocada financeira em 2008.

Palavras-chave: Woody Allen, cinema, literatura, empreendedorismo 


\begin{abstract}
The aim of this dissertation is to understand the role of the contemporary subject in the film Match Point (2005), by Woody Allen. In Allen's career, this film represents the moment of a sort of exile. Due to funding problems in the United States, the New-Yorker director goes to Europe. In the center of financial capitalism, an Irishman joins the British elite. The protagonist combines the social values of entrepreneurship in a historical moment that precedes the global financial crisis in 2008.
\end{abstract}

Keywords: Woody Allen, cinema, literature, entrepreneurship 


\section{Sumário}

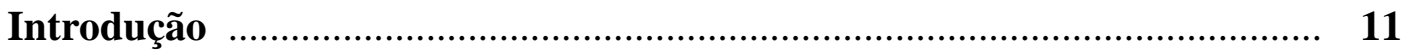

Capítulo I. A questão do protagonista ................................................. 22

1.1 Apresentação de Chris Wilton ...................................................................... 22

1.2 Apresentação de Nola Rice ................................................................ 40

1.3 Uma tragédia americana .................................................................. 46

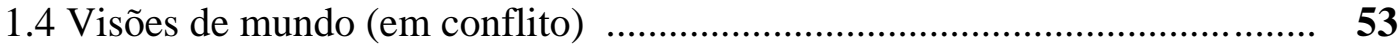

1.5 Capital e empreendedorismo .......................................................... 59

Capítulo II. Aliança de classes ..................................................................... 72

2.1 Dinheiro, jogo e prostituição ............................................................. 72

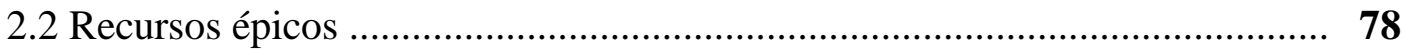

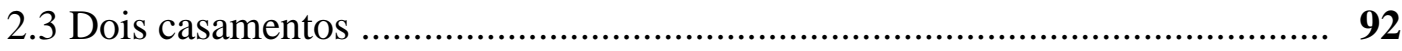

2.4 A intervenção corporativa nas artes ....................................................... 98

Capítulo III. O sujeito contemporâneo ........................................................ 123

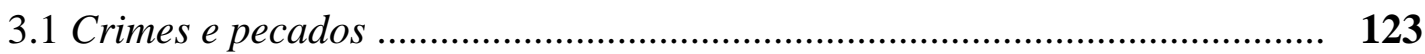

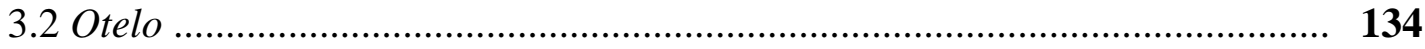

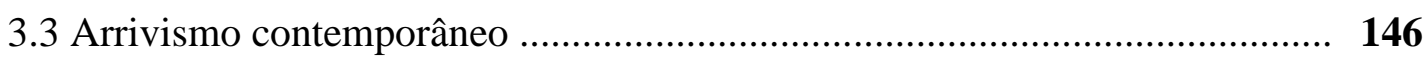

3.4 A espetacularização do assassinato ........................................................ 167

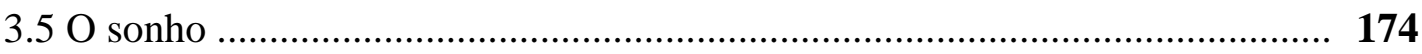

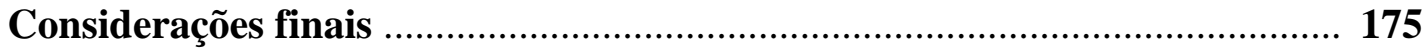

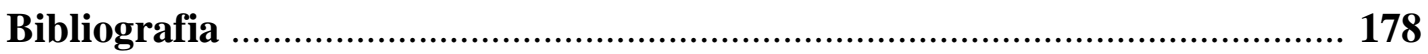

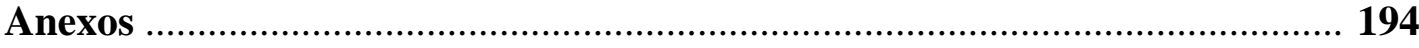




\section{Introdução}

"O cinema, sem dúvida, é a mais internacional das artes. Não apenas porque as plateias de todo mundo veem filmes produzidos pelos mais diferentes países e pelos mais diferentes pontos de vista. Mas particularmente porque o filme, com suas ricas potencialidades técnicas e sua abundante invenção criativa, permite estabelecer um contato internacional com as ideias contemporâneas".

Sergei Eisenstein, A forma do filme.

\section{a. Ideias contemporâneas}

Em 2005, ano de lançamento de Ponto Final - Match Point ${ }^{1}$, Woody Allen surpreende a crítica cinematográfica ao filmar novamente na Europa ${ }^{2}$. Para o cineasta, o motivo da mudança foi apenas um: "Filmo no exterior porque é mais fácil para arrecadar dinheiro sob as circunstâncias que eu preciso. Eu poderia arrecadar o dinheiro nos Estados Unidos, mas isso implica deixar que os estúdios leiam o meu roteiro e ter que contar para eles quais são os atores que eu quero chamar, e eu não quero negociar isso com eles. Eu não quero ouvir que eles pensam que o roteiro começa bem, mas perde o ritmo no final, ou que começa lento e melhora no final, ou "Meu Deus, por favor, não chame essa pessoa". Eu apenas não quero que ninguém interfira. Quando eu arrecado dinheiro na Europa, eu consigo em circunstâncias que são muito boas para mim artisticamente. E por causa disso, eu posso fazer um filme como Match Point. Se eu tivesse que ir e sentar com os executivos do estúdio e argumentar, "Olha, eu quero fazer um filme sério sobre esta família", eles iriam olhar para mim e dizer, "Onde estão as risadas?" Ou, eles veriam o dinheiro deles desaparecer em um poço em algum

\footnotetext{
${ }^{1}$ Neste trabalho, utilizaremos apenas o nome em inglês do filme: Match Point, pois se trata de locução substantiva em português, utilizada na grafia inglesa, para designar o ponto decisivo que, uma vez obtido, encerra um jogo de tênis (ou de vôlei). Disponível em: <http://houaiss.uol.com.br/busca.jhtm?verbete=match+point\&stype=k>. Acesso em: 13 jun. 2010.

2 O primeiro filme na Europa da carreira de Woody Allen como diretor é A última noite de Boris Grushenko (1975), filmado nas cidades de Paris e Budapeste. Em 1996, Allen volta a filmar na Europa em Todos dizem eu te amo.
} 
lugar" ${ }^{\prime 3}$ Nas inúmeras entrevistas que concedeu a respeito de Match Point, a resposta de Allen foi categoricamente a mesma: seu exílio para a Europa deve-se aos problemas de financiamento nos Estados Unidos. Após o 11 de setembro de 2001, do ponto de vista da arrecadação de bilheteria para os cofres da indústria cinematográfica norte-americana, Allen volta a preocupar os investidores de seu país: os filmes Dirigindo no escuro ${ }^{4}$ (2002), Igual a tudo na vida (2003) e Melinda e Melinda (2004) não passaram de 5 milhões de dólares ${ }^{5}$.

No entanto, para a crítica cinematográfica, a partir de Match Point houve uma espécie de ressurgimento no interesse pela obra de Allen. Conforme argumenta Marcos Soares, "os eventos antes e depois do 11 de setembro pareciam ter animado os cineastas mais sérios a arregaçar as mangas. [...] De fato, muitos dos novos filmes possuem no conjunto, a despeito de (ou talvez, devido a) acertos e erros particulares, um vigor que não deixa de ser surpreendente, tanto da perspectiva da fatura estética quanto da escolha dos conteúdos"6. Assim como outros cineastas ${ }^{7}$, Woody Allen também enfoca o mundo das corporações ${ }^{8}$ no momento anterior à crise financeira de 2008. Em Match Point, o cineasta norte-americano apresenta a trajetória de um jovem irlandês, compondo o sujeito contemporâneo, as

3 Ver Matloff, Jason. "Woody Allen Speaks!”. Premiere. Extraído de: $<$ http://www.premiere.com/article.asp?section_id=6\&article_id=2539>. Acesso em: 13 jun.2010.

${ }^{4}$ Cabe lembrar que os nomes em inglês Hollywood Ending e Anything Else dos filmes de Allen, realizados após o 11 de setembro, já avisavam que o cineasta enfrentava dificuldades com os patrocinadores da indústria cinematográfica norte-americana. O filme de 2002 expõe explicitamente esse conflito. Na verdade, Allen sempre teve problemas com os produtores de Hollywood. Em sua primeira experiência no cinema como ator e roteirista em $O$ que é que há, gatinha? (1965), ele relata a Stig Björkman que os "produtores de Hollywood conseguiram filmar o roteiro com tudo o que todo mundo detesta nos filmes de Hollywood. Pessoas que não tinham nenhum senso de humor decidiram o que era engraçado e o que não era. Essas pessoas colocavam as suas namoradas nos papéis. Eles escreviam personagens especiais para acomodar as estrelas, não importando se esses personagens funcionavam ou não. $\mathrm{O}$ pior pesadelo que qualquer um poderia imaginar. E toda e qualquer decisão artística que foi feita estava errada". Ver Björkman, Stig. Woody Allen on Woody Allen. New York: Grove Press, 1993 (2002), p.10.

${ }^{5} \mathrm{O}$ custo de cada filme de Woody Allen está estimado em 15 milhões de dólares, orçamento considerado baixo para os padrões de Hollywood. A maior bilheteria já conseguida pelo cineasta foi com Hannah e suas irmãs (1986), total estimado em US\$ 40 milhões. Assim como Setembro (1987) que arrecadou pouco menos de 500 mil dólares, Dirigindo no escuro (2002), Igual a tudo na vida (2003) e Melinda e Melinda (2005) não tiveram faturamento superior a 5 milhões de dólares. Com Match Point, Allen voltou a arrecadar com seus filmes, o ganho final nas bilheterias de todo o mundo ficou em US\$ 23.151.529. Apenas a título de comparação, o cineasta Steven Spielberg em Guerra dos mundos (2005) arrecadou US\$ 234.280.354.

${ }^{6}$ Ver Soares, Marcos. "O projeto inacabado de Cidadão Kane”. In: Crítica cultural materialista / Marcos Soares e Maria Elisa Cevasco (orgs.). São Paulo: Humanitas, 2008, p.168.

${ }^{7}$ Entre eles destacam-se: $O$ que você faria? (El Método), de Marcelo Piñeyro; O grande chefe (2006), de Lars von Trier e A questão humana (2007), de Nicolas Klotz, entre outros.

${ }^{8}$ Assim como os artistas, os executivos de finanças sempre aparecem nos filmes de Allen. Na abertura de Hannah e suas irmãs, Elliot [Michael Caine] se apresenta em voz over como um "consultor financeiro respeitado" enquanto idolatra a cunhada, Lee. 
habilidades, os valores e as destrezas do empreeendedor, no centro do capitalismo financeiro britânico.

Se por um lado parece haver uma espécie de excepcionalidade em Match Point, argumentaremos que, por outro lado, essa perspectiva, a do conteúdo social sedimentado nos dilemas subjetivos, perpassa a obra do cineasta em diversos momentos.

\section{b. Revisão bibliográfica}

Os livros publicados sobre a obra de Woody Allen chegam às centenas. Entre eles, destacam-se as compilações de entrevistas com o diretor, realizadas por Eric Lax e Stig Björkman, entre outros. Nos últimos anos, em especial a partir de 2002, a consagração de Woody Allen como auteur aparece nos livros sobre a obra do diretor nova-iorquino. Entre os livros que trazem análises sobre os filmes de Allen, houve um esforço para o chamado estudo sério do cineasta norte-americano, notadamente nos trabalhos de Sander Lee ${ }^{9}$ e Sam Girgus ${ }^{10}$. Entretanto, esse esforço de análise apurado já pode ser encontrado em diversos ensaios publicados ao redor do mundo em anos anteriores. Muitos deles foram compilados por Charles Silet ${ }^{11}$.

Nas coletâneas de ensaios e entrevistas e nos livros publicados sobre o autor, há um esforço de sistematização. Todos os autores buscam entender e identificar uma perspectiva que perpasse a vasta obra do diretor. Todavia, há uma enorme diversidade de temas analisados pelos críticos (religião, gastronomia, judaísmo, humor, justiça, entre outros) e muitas vezes, aspectos irônicos nos filmes de Allen são levados a sério. Na bibliografia que analisamos para esta pesquisa, pudemos identificar alguns procedimentos recorrentes que foram identificados pelos críticos. Porém, estes aspectos são localizados, restringem-se a observações periféricas em um ou outro artigo sobre a obra de Woody Allen.

\footnotetext{
${ }^{9}$ Lee, Sander. Eighteen Woody Allen Films Analyzed: Anguish, God and Existentialism. McFarland \& Company, 2002.

${ }^{10}$ Girgus, Sam. The Films of Woody Allen $-2^{\text {nd }}$ ed. Cambridge: Cambridge University Press, 2002.

${ }^{11}$ Silet, Charles (ed.). The Films of Woody Allen: critical essays / ed. by Charles L. P. Silet. Oxford: The Scarecrow Press, 2006.
} 
Das entrevistas com o diretor, publicadas em livro, selecionamos as que foram realizadas por Eric Lax e Stig Björkman. O norte-americano Eric Lax é o biógrafo oficial de Woody Allen desde 1971 até hoje. Lax acompanha todo o processo fílmico do cineasta, realizando entrevistas e publicando livros e biografias sobre Allen. O jornalista norteamericano optou por dividir seu amplo material contemplando "cada um dos sete aspectos principais da realização de um filme, da ideia à trilha sonora, terminando com um capítulo em que Allen reflete sobre sua carreira. Cada capítulo começa no início dos anos 70 e termina em 2006 ou 2007, de forma que, dependendo, digamos, do interesse no elenco ou na edição, eles podem ser lidos em qualquer ordem" $" 12$.

Por sua vez, nas entrevistas realizadas por Stig Björkman, o jornalista e cineasta sueco concentra-se nos aspectos técnicos e temas recorrentes na obra de Allen. A coletânea de entrevistas apresenta cada um dos filmes de Allen que estão divididos cronologicamente por capítulos do livro. Björkman afasta-se um pouco da imagem que se construiu em torno do cineasta: "O Woody Allen que eu aprendi a conhecer durante o trabalho para este livro, não tem muita semelhança com a film persona que a gente está acostumado a ver na tela, o lobo solitário e o neurótico incurável [...], ao contrário, foi o trabalhador disciplinado e decidido, artista sério e consciente que faz muitas exigências a si mesmo e que se recusa a comprometer sua arte e sua visão de mundo" ${ }^{\prime 13}$. Os encontros de Björkman e Allen vão de 1986 a 2002. No prefácio do livro, o jornalista (também responsável pelo livro de entrevistas Bergman on Bergman) salienta as condições de produção dos filmes de Allen: “A posição de Woody Allen no mundo do cinema é única. Ele tem um contrato com seus produtores que lhe garante total liberdade para escrever e dirigir um filme por ano - pelo menos. O contrato prevê controle ilimitado do lado de Woody em relação à escolha do tema, roteiro, atores e membros da equipe, corte final e assim por diante. A única condição é que ele se mantenha dentro dos

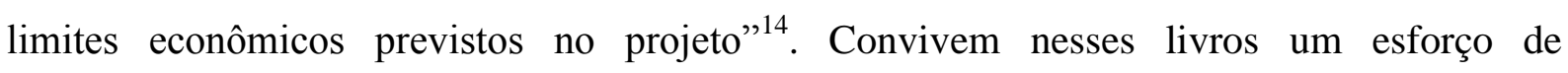
sistematização que é importante para uma análise consequente da obra do cineasta ao lado de informações nas quais o leitor deve "confiar desconfiando". Como é comum nas entrevistas que Woody Allen concede, há despistes e ironias que fazem com que cada informação deva ser testada no confronto com os filmes.

\footnotetext{
${ }^{12}$ Lax, p. 16.

${ }^{13}$ Björkman, p.xv.

${ }^{14}$ Iibid, p.Xv.
} 
Para a nossa pesquisa, o melhor exemplo de entrevista já realizada com Woody Allen é “Meetin' WA" (1986), de Jean-Luc Godard, pois a ironia é o tema estruturador desta narrativa cinematográfica. Durante “Meetin' WA”, observamos Allen sob o ponto de vista de Godard. Na primeira pergunta, Godard indaga se Allen tem medo da imprensa. Há um círculo negro cobrindo a imagem do cineasta norte-americano. Allen responde: "Não. A imprensa tem sido sempre boa comigo, melhor do que eu mereço. Eu nunca me sinto intimidado pela imprensa, ela sempre me protegeu muito e me apoiou ao longo dos anos, até mesmo em vários momentos em que eu não merecia. Então, eu tenho, na maioria das vezes, uma ótima relação com a imprensa". O círculo negro em torno do rosto de Woody Allen cria distanciamento em relação ao discurso do cineasta. Outra estratégia utilizada por Godard é o uso de intertítulos. Após os comentários sobre a imprensa, o cineasta francês insere o intertítulo: "Normal Man".

Godard pergunta ao colega norte-americano a respeito do uso de intertítulos em seus filmes. Allen responde que os utiliza "como um dispositivo literário. [...] Quando eu estava escrevendo Hannah e suas irmãs, pensava na forma de um romance no qual há um pouco de ação em uma área e depois vamos para outra onde há ação e voltamos para a primeira e depois para outro lugar... Para mim, nunca foi uma ideia de cinema, mas sempre de literatura." Em francês, Godard pede para que Allen explique, por exemplo, por que no filme Hannah, ele usa a expressão "Stanislavski catering companion" (companhia bufê Stanislavski). Nesse ponto, há um corte abrupto na entrevista e a introdução da tela preta com o intertítulo, no qual se lê:

\section{STALINE}

\section{LOVES}

\section{SKI}

A intenção irônica de Godard, que associa o método Stanislavski de atuação teatral ao ditador Stalin afirmando que o último adora esquiar, é bastante explícita. Ele utiliza os intertítulos e a música extra-diegética, o jazz, para, assim como Allen em Hannah, fazer um comentário irônico sobre o método Stanislavski, a relação de Allen com a imprensa, entre outros aspectos que perpassam o filme inteiro. Na resposta à pergunta de Godard sobre o uso de intertítulos, Allen esquiva-se: "Esse é apenas um nome lógico". Ao final do filme de 
Godard, Allen diz que prefere "lutar com o filme [na montagem] a lutar com outras coisas." Nesse ponto, a imagem de Allen aparece em câmera lenta. A tela fica escura e a cena é interrompida. No momento seguinte, Godard entra em uma sala repleta de fotografias, fotogramas e livros publicados sobre Woody Allen. Enquanto reúne os objetos em uma pilha, o cineasta francês narra: "Os homens permanecem em seus apartamentos, em suas ruas, em seus carros. É isso, o encontro acabou."

Em 'Meetin' $W A$ ”, Godard apresenta a ironia como elemento central, ponto estruturador da obra de Woody Allen. Essa questão também foi abordada de forma esparsa por alguns críticos. Entre eles destacam-se as análises de: Christopher Morris, Thomas Schatz, Celestino Deleyto, Sander Lee, Sam Girgus, Christopher Beach, Robert Stam, Ella Shohat e Luiz Renato Martins. Nesse ponto, passaremos à exposição das contribuições feitas pela crítica da obra de Woody Allen.

Em texto sobre a ironia cômica de Allen, Christopher Morris aponta para o uso irônico da música nos filmes do cineasta. Segundo o crítico, "os artistas e os amantes (e o público) dos filmes de Allen são com frequência e cruelmente ridicularizados pelas trilhas sonoras, que usam a música tanto para minar essas expectativas como para fornecer instâncias artísticas de integridade e da harmonia indisponível na vida. Um exemplo simples é a música sentimental de Marvin Hamlisch a exaltar "o amor, a dedicação e o amanhecer”, em seguida, a comparação crua entre fazer amor e a prática do boxe que encerra Bananas " ${ }^{\prime 15}$.

Em ensaio sobre Annie Hall - noivo neurótico, noiva nervosa ${ }^{16}$ (1977), Thomas Schatz aponta como princípio organizador da narrativa em Annie Hall, "a vida do narrador cômico, com as sequências seguindo um padrão associativo e não cronológico" ${ }^{17}$. O crítico argumenta que a técnica de Woody Allen aproxima-se da ficção moderna, pois faz "o leitor participar do

\footnotetext{
${ }^{15}$ Morris, Christopher. "Woody Allen's Comic Irony" (1987). In: Silet, Charles (ed.). The Films of Woody Allen: critical essays / edit. by Charles L. P. Silet. Oxford: The Scarecrow Press, 2006, p.54.

${ }^{16}$ As traduções dos filmes de Allen são problemáticas, entre elas, destaca-se: Annie Hall que em português ficou Noivo neurótico, noiva nervosa.

${ }^{17}$ Ibid, p.128.
} 
ato de criação"18. Schatz propõe que o filme de Allen "demanda virtualmente que o espectador adote uma perspectiva modernista" ${ }^{\prime 19}$.

A figura do narrador reaparece entre os críticos, também em uma análise sobre Annie Hall, de Celestino Deleyto. De acordo com o crítico, o narrador em primeira pessoa aparece como personagem em cena, falando diretamente para o espectador. Deleyto argumenta que o narrador "começa em um tom confessional, com a expectativa de que o espectador confie nele" ${ }^{20}$. Contudo, prossegue o crítico, conforme a narrativa progride, o espectador deve perceber os eventos narrados como "memória não-confiável”. De maneira similiar a Schatz, Deleyto identifica o retorno ao modelo clássico em Manhattan: "O filme mergulha no estilo clássico, até então desconhecido em Allen, sem autoconsciência ou abordagem direta à audiência. A vivacidade do diálogo é apresentada em tomadas clássicas"21.

Zelig (1983) é, provavelmente, o filme que trouxe as melhores análises a respeito da obra de Allen. O filme Zelig, obra sobre um herói sem caráter que se transforma para se adaptar a cada ambiente onde se encontra, será figura fundamental para entendermos Match Point. No filme de 1983 que aborda a questão do pós-modernismo como tema, muitos dos críticos não perceberam a ironia que perpassa toda a narrativa. Christopher Beach atentou para o sentido pós-moderno dos filmes do cineasta. Segundo Beach, Allen pode ser considerado "um típico cineasta pós-moderno" 22 , no sentido de que seus filmes apontam para uma "sociedade sem classes",23. Para o crítico, Zelig "mostra a dissolução das fronteiras de classe, e pode ser lido como uma alegoria da ruptura pós-moderna de identidade de classe. Zelig não é mais sujeito de uma determinada rede de identidade de classe, mas é definido apenas em relação àqueles com quem ele entra em contato. Por se apropriar quase

\footnotetext{
${ }^{18}$ Schatz, Thomas. "Annie Hall and the Issue of Modernism" (1982). In: Silet, Charles (ed.). The Films of Woody Allen: critical essays / edit. by Charles L. P. Silet. Oxford: The Scarecrow Press, 2006, p.126.

${ }^{19}$ Ibid, p. 127.

${ }^{20}$ Deleyto, Celestino. "The Narrator and the Narrative: The Evolution of Woody Allen's Film Comedies". In: Silet, Charles (ed.). The Films of Woody Allen: critical essays / edit. by Charles L. P. Silet. Oxford: The Scarecrow Press, 2006, p.27.

${ }^{21}$ Ibid, p.29.

${ }^{22}$ Beach, Christopher. "Is there a class in this text? Woody Allen and Postmodern Comedy". In: Class, Language, and American Film Comedy. Cambridge: Cambridge University Press, 2002, p.156.

${ }^{23}$ Idem, p.172-173.
} 
imediatamente das características sociais, padrões de fala, e opiniões das pessoas ao seu redor, Zelig torna-se o símbolo de uma sociedade sem classes."24.

A análise do pós-modernismo pode ser encontrada também em texto de Robert Stam e Ella Shohat, os quais argumentam que quem é pós-moderno é o personagem Zelig, não o filme. Os críticos entendem a utilização do pós-modernismo em Zelig como material: “à primeira vista Zelig poderia dar a impressão de partilhar de certas características do pósmodernismo neoconservador: um estilo enraizado em pastiches, o historicismo eclético de textos reciclados, a visão da disponibilidade do passado apenas como representação estereotipada, uma espécie de ironia em branco. Mas, apesar de a personagem Zelig, pelo menos em sua fase camaleônica (e poder-se-ia dizer que Zelig nunca abandona sua fase camaleônica), representar de fato o pós-moderno, já não se pode dizer o mesmo do filme Zelig. Não se trata de uma trivialização da história, como se chegou a dizer do filme, mas sim de se lançar uma certa luz na natureza construída e manipulável da história enquanto disciplina mediada pela indústria cultural. Ainda que se tratasse de exagero dizer que Zelig é um exemplo do que Hal Foster chama de 'pós-modernismo de oposição', é possível discernir uma leitura oposta e antecipatória do que, em alguns aspectos, vem a ser um texto recalcitrante.",25

O sentido político da obra de Allen volta ao debate na análise de Luiz Renato Martins. Segundo o crítico, em Maridos e esposas (1992) a técnica serve a um conteúdo específico, a saber, o de situar "concretamente este redimensionamento do sujeito aos parâmetros do mercado" ${ }^{26}$. Nesse sentido, propõe Martins, "as subjetividades se dispõem como artigos de consumo no mercado [...]. O afeto, qualquer que seja, é considerado aqui como coisa e como elemento para quantificação" ${ }^{27}$. O crítico analisa uma cena chave do filme em que a liberdade de escolha afetiva aparece entre prateleiras de supermercado. Durante o diálogo, Jack [Sydney Pollack] explica a Gabe [Woody Allen] os motivos que o fizeram largar a esposa, Sally [Judy Davis] para ficar com a professora de ginástica, Sam [Lysette Anthony]. Os motivos subjetivos de Jack aparecem coisificados no cenário de compras. As subjetividades são

\footnotetext{
${ }^{24}$ Iibid., p.172-173.

${ }^{25}$ Stam, Robert; Shohat, Ella. “Zelig”. In: Labaki, Amir (Org.) O Cinema dos anos 80. São Paulo: Brasiliense, 1991, p.141.

${ }^{26}$ Martins, Luiz Renato. "Woody Allen: entre a lírica e a política”. In: Novos Estudos CEBRAP, N³8, 3/1994, p.57

${ }^{27}$ Ibid, p.57.
} 
espetacularizadas e banalizadas, tudo vem circunscrito por relações de mercado: "As subjetividades se dispõem como artigos de consumo no mercado. Os pares amorosos, que se formam ao longo do filme, estão condicionados por cenários profissionais: Judy [Mia Farrow], a esposa do protagonista, apaixona-se por um colega da redação, e Gabe [Woody Allen], o protagonista, por uma aluna"28.

$\mathrm{Na}$ conclusão do ensaio, Martins destaca a clareza e radicalização do balanço apresentado no filme: “(...) feito, convém notar, no fim do período neoliberal ortodoxo Reagan-Bush (1980-92) — do seu contexto sócio-econômico e cultural, especificamente pautado por uma ilusão - a saber, pela premissa de que a liberdade subjetiva esteja vinculada ontologicamente com as relações de mercado, com a dita liberdade de iniciativa (por essência unilateral, pois confronta só sujeito e coisa, em vez de um sujeito e outro)."29

Para o crítico, o aspecto confessional ou autobiográfico da obra de Allen passaria por uma reestruturação após Maridos e esposas, conforme o próprio personagem, interpretado pelo diretor, revela na conclusão do filme, “ (...) sua nova obra, em vez de confessional, seria política" ${ }^{30}$. No entanto, procuraremos argumentar que até mesmo em Maridos e esposas esse comentário é irônico, novamente um despiste para a crítica, pois na obra de Allen os aspectos pessoais, confessionais, aparecem a todo o momento interligado com as questões políticas. Ao final de Maridos e esposas, o casal restabelecido Sally e Jack conta ao documentarista por que resolveram reatar o casamento: "Estamos indo muito bem. Aprendemos a tolerar os problemas um do outro", enquanto os rostos dos personagens, repletos de conformismo, desmentem o discurso proferido para a câmera. O casal prossegue, argumentando sobre a incapacidade de se relacionarem sexualmente:

[Judy]: "Você aprende a lidar com isso e a empurrar para debaixo do tapete."

[Jack]: "E funciona. Isso que é estranho. Não é ruim.”

[Judy]: "Você não pode forçar-se a se conformar com uma visão abstrata do amor, ou, você sabe, do casamento. Cada situação é diferente."

\footnotetext{
${ }^{28}$ Ibid., 57-59.

${ }^{29}$ Ibid., 59-60.

${ }^{30}$ Ibid., p.54.
} 
[Jack]: "O negócio é: seja o que for. Tudo vai ser diferente. Quer dizer, a nossa é apenas uma maneira, outros são de outra forma."

Em Maridos e esposas, Allen enuncia, diante da câmera, que passará do confessional ao político. No entanto, conforme procuraremos demonstrar ao longo deste trabalho, a perspectiva subjetiva, os valores e hábitos sociais já são em si políticos. Em Match Point, observamos o momento de formalização mais bem acabado desta tendência onde o confessional e o político relacionam-se a todo o momento. Momento em que Allen formaliza uma tendência que ele vinha esboçando em obras anteriores sem que ela se cristalizasse plenamente.

\section{c. Divisão dos capítulos}

No primeiro capítulo da dissertação, exporemos a questão do protagonista. O filme relaciona a trajetória do protagonista à tradição no cinema e na literatura. Notadamente, por meio da referência ao filme Um lugar ao sol, de George Stevens, e indiretamente, ao romance Uma tragédia americana, de Theodore Dreiser, o qual o filme de Stevens tem como base. Em outro ponto da análise, mostraremos como existem duas visões de mundo (em conflito). Por fim, apresentaremos a ideologia que subsiste no filme, a saber, o discurso do empreendedorismo.

No segundo capítulo, apresentaremos a peculiar configuração da aliança de classes que o filme expõe. Para isso, mostraremos como o dinheiro, o jogo e a prostituição são temas que aparecem interligados ao longo do filme. Em seguida, exporemos como o filme faz uso de alguns recursos caros ao épico. A referência às cenas de casamentos retoma o universo de Jane Austen, colocando-o em questão. Ao final, mostraremos como as artes configuram-se no filme a partir da intervenção corporativa.

No terceiro e último capítulo, apontaremos para a representação do sujeito contemporâneo, conforme exposto em Match Point. Para isso, retomaremos o filme Crimes e pecados em termos comparativos. Em seguida, apresentar-se-á a utilização da ópera Otelo 
como estrutural para a narrativa. O tema do arrivismo contemporâneo ganha contornos centrais no filme que estabelece diálogo com o romance Crime e Castigo, de Dostoievski. Mostraremos também como Allen apresenta a espetacularização do assassinato, em especial, no papel da polícia. Por fim, apresentaremos o tema do sonho e que tipo de sujeito histórico ele configura. 


\section{Capítulo I - A questão do protagonista}

Segundo um dos maiores teóricos do cinema norte-americano David Bordwell, “o star system tem como uma de suas funções, a invenção de um protótipo de personagem forte para cada estrela que é, então, ajustado às necessidades específicas do papel. O personagem mais 'explícito' é normalmente o protagonista, que se torna o principal agente motivador, o alvo de qualquer restrição narrativa e, o principal objeto de identificação do público"31. A priori, o filme Match Point, oferece o protagonista como centro de consciência da narrativa. Não obstante, conforme procuraremos demonstrar ao longo deste trabalho, o que acontece é o contrário, pois existem diversos recursos utilizados no filme que relativizam o discurso do protagonista, colocando a perspectiva apresentada por ele à prova.

\subsection{Apresentação de Chris Wilton}

"Na sua terra, os irlandeses não tinham nada a perder, na Inglaterra muito a ganhar; e desde que se soube na Irlanda que na margem leste do canal St. George qualquer homem forte tinha assegurados trabalhos e bons salários, bandos de irlandeses atravessaram-no todos os anos."

Friedrich Engels, A situação da classe trabalhadora na Inglaterra.

Em Match Point, o foco narrativo se apresenta inicialmente próximo ao protagonista Chris Wilton, o que provoca a aproximação entre narrador e espectador. Se tomarmos essa

perspectiva, a história pode ser entendida como a da vitória de um jovem irlandês, apadrinhado pela classe alta britânica e agraciado pela sorte. Nesse sentido, pode-se argumentar que o filme endossa o ponto de vista do protagonista à medida que comprova a tese do "papel da sorte na vida" apresentada no prólogo.

\footnotetext{
${ }^{31}$ Bordwell, David. Narration in the fiction film. The University of Wisconsin Press: Methuen, 1985, p.157.
} 
No entanto, se no cinema a narração é "sempre resultado da interação entre várias instâncias que se manifestam através de materiais heterogêneos, simultâneos",32, cabe à crítica verificar "se as várias instâncias (palavra, mise-en-scène, olhar da câmera, montagem, música extra-diegética) se organizam para trabalhar 'na mesma direção', de modo a fazer sentido em se falar em um ponto de vista da narração" ${ }^{33}$. Um dos objetivos deste trabalho será o de identificar o princípio narrativo do filme e entender se as diversas instâncias cinematográficas corroboram, ou não, a perspectiva do protagonista.

Nossa hipótese entende que se a narração aproxima-se do protagonista. Entretanto, o "autor implícito" 34 tenciona essa convergência, mobilizando recursos para que "não fiquemos muito identificados e nos mantenhamos distanciados em face dos personagens e dos seus desastres" ${ }^{\prime 35}$. Nesse sentido, apontaremos ao longo do trabalho os elementos que permitem ao espectador questionar a trajetória ascendente do protagonista. Um dos recursos que problematizam o foco narrativo, fazendo com que a visão do protagonista não se apresente como absoluta, é a utilização da ópera no filme. Além da música, existem outras instâncias tais como os cortes abruptos de cena, os diálogos entre os personagens, as locações utilizadas, o olhar da câmera, a montagem, a composição da mise-en-scène, entre outros recursos - que permitem ao espectador colocar o foco narrativo em questão. No intuito de expor a configuração do foco narrativo no filme, passaremos à descrição de sequências específicas.

O primeiro "choque de estranheza",36 que permite que o espectador desconfie da visão que será apresentada pelo protagonista ocorre logo no início do filme, na apresentação dos créditos seguida pelo prólogo. Os créditos e o prólogo vêm acompanhados pela música extradiegética. $\mathrm{O}$ uso da música no filme guarda semelhanças com a utilização épica na qual "a música e a ação são tratadas como componentes completamente independentes" ${ }^{\text {"37 }}$. Conforme explica Anatol Rosenfeld, a utilização da música no teatro épico é "um dos recursos mais

\footnotetext{
${ }^{32}$ Xavier, Ismail. "O olhar e a voz: a narração multifocal do cinema e a cifra da História em São Bernardo". In: Literatura e Sociedade: Revista de Teoria Literária e Literatura Comparada. São Paulo, n. 2, 1997, p.131.

${ }^{33}$ Iibid., p. 131.

${ }^{34}$ Segundo Wayne Booth, o autor implícito seria uma espécie de "figura implícita do autor que permanece atrás da cena como diretor, operador de marionetes, ou como um Deus indiferente, silenciosamente aparando as unhas. O autor implícito é sempre distinto do "autor verdadeiro" - seja ele quem for - que cria uma versão superior de si mesmo, uma "segunda natureza", durante o processo de criação". Ver: Booth, Wayne C. The rhetoric of fiction. The University of Chicago Press, 1961, p.151

${ }^{35}$ Rosenfeld, Anatol. O teatro épico. São Paulo: Perspectiva, 2002, p.157.

${ }^{36}$ Ibid, p. 157.

${ }^{37}$ Brecht, Bertolt (1898-1956). Brecht on Film and Radio - translated and edited by Marc Silberman. Methuen, 2000, p. 13 .
} 
importantes de distanciamento: o de o autor se dirigir ao público através de coros e cantores" "38. A função da música seria a de "comentar o texto, de tomar posição em face dele e acrescentar-lhe novos horizontes. Não intensifica a ação; neutraliza-lhe a força encantatória.",39

No caso de Match Point, a música utilizada no prólogo do filme é a ária "Uma furtiva lágrima", da ópera $O$ Elixir de Amor ${ }^{40}$. O filme sugere a associação entre a imagem apresentada da quadra de tênis, a ópera de Donizetti e o discurso do narrador. No entanto, "os três elementos, ação, música e imagem, aparecem juntos, mas ainda separados" ${ }^{41}$ no prólogo do filme.

A escolha do Elixir entre as óperas pode indicar que o filme estabelecerá relação semelhante a da música extra-diegética, na qual se acompanha o amor do camponês Nemorino que, apaixonado pela jovem rica Adina, e sem conseguir conquistá-la, cai na armadilha do charlatão Dulcamara ao comprar vinho barato pensando se tratar de um poderoso elixir. Não obstante, a ópera parece se contrapor às ideias apresentadas pelo protagonista.

O som da gravação antiga e a recorrência de chiados sugerem certa impureza à sonoridade. Além dos ruídos, a utilização da ópera feita por Allen suprime o início da famosa romanza, interpretada por Enrico Caruso ${ }^{42}$. Há uma intervenção nos trechos de óperas utilizados, característica que exige que o espectador adote uma postura de investigador, indagando-se sobre a razão da intervenção do cineasta. O próprio Allen explicita que a utilização de gravações com chiado em Match Point foi proposital: "eu queria que as

\footnotetext{
${ }^{38}$ Ibid., p.159.

${ }^{39}$ Ibid., p. 160.

${ }^{40}$ A ópera de Gaetano Donizetti, de 1832, trata da história de um jovem camponês (Nemorino) apaixonado pela bela e rica Adina. Tímido, Nemorino não consegue conquistar sua amada. Ele recorre a Dulcamara em busca de um poderoso elixir. Percebendo que se trata de um pobre camponês, o charlatão vende um frasco de vinho Bordeaux barato como se fosse elixir. Após entusiasmar-se sob o efeito do Bordeaux, Nemorino conquista Adina. Sem saber que seu tio rico morreu e que se tornara herdeiro de uma grande fortuna, o jovem camponês atribui sua sorte ao elixir. Dulcamara vê seu prestígio tão aumentado que vende todo o estoque de Bordeaux aos aldeões por um preço que o faz rico de uma hora para outra. O charlatão sai da cidade como o "grande Dulcamara, único entre os doutores". Na ópera é importante ressaltar também que diferentemente dos aldeões, o espectador sabe que Dulcamara é um trapaceiro. Resumo meu a partir de: Donizetti, Gaetano. O Elixir de Amor / tradução Manuel Rosa. Lisboa: Série Óperas Imortais, Editorial Notícias, 198?, pp.24-25 e Kobbé, Gustave. $O$ Livro completo da ópera. Rio de Janeiro: Jorge Zahar Ed., 1997, p.261-263.

${ }^{41}$ Brecht, op.cit., p.13-14.

42 "Foi praticamente por causa da maravilhosa interpretação de Caruso nesta ária que a ópera veio a ser montada na Metropolitan Opera House de Nova Iorque, em 1904". Trata-se da gravação utilizada por Allen no filme. Ver: Kobbé, op. cit., p.262.
} 
gravações soassem antigas na trilha, para fazer o público ouvir os chiados e saber que eram gravações velhas, não uma trilha."

A recusa do cineasta em compor uma trilha e a manipulação deste e de outros trechos de ópera usados no filme sugere que o uso da ópera no filme é calculado. Como procuraremos demonstrar, a utilização da música no filme não é aleatória, mas funciona como um comentário sobre a ação. Allen escolhe e intervêm deliberadamente em certos trechos das óperas utilizadas, conforme apresentaremos ao longo deste trabalho. Em "Uma Furtiva Lágrima" ${ }^{44}$, como em outras árias utilizadas no filme, Allen seleciona um trecho específico. A ária foi cortada pelo cineasta que não faz uso da abertura que a nomeia . A música extradiegética começa em meio à célebre interpretação de Caruso. $\mathrm{O}$ trecho foi estendido e repetido, como se reafirmasse ao espectador o contraste entre a ópera, o discurso do narrador e a imagem apresentada.

Diferentemente de um cenário antigo, conforme sugere a época de gravação da ópera, o filme apresenta uma quadra de tênis e uma bolinha sendo jogada de um lado para o outro da quadra, em câmera lenta, sem que se vejam quem são os jogadores. Enquanto acompanhamos o movimento da bolinha e ouvimos a interpretação de Caruso é incluída à imagem outra instância extra-diegética, a saber, a voz over apresentando o mote da trama:

O homem que disse, prefiro ter sorte a ser bom entendeu profundamente a vida. As pessoas temem ver como grande parte de suas vidas depende da sorte. É assustador pensar que tanta coisa foge ao nosso controle. Há momentos em um jogo quando a bola bate no topo da rede, e por um segundo, ela pode ir para o outro lado ou voltar. Com um pouco de sorte, ela cai do outro lado e você ganha. Ou talvez isso não aconteça e você perca. ${ }^{45}$

No momento em que ouvimos a frase: "a bola bate no topo da rede", a câmera congela a imagem, ou seja, a bolinha de tênis fica parada no meio da rede, enquanto o protagonista termina seu discurso afirmando que dependendo do lado em que a bolinha cair, estará decidido o jogo. Assim, neste breve prólogo o espectador tem acesso à trama sob perspectivas contrastantes. A primeira, suscitada pela ópera, apresenta a história do falso elixir; a segunda, exposta pela voz over argumenta sobre o papel da sorte na vida.

\footnotetext{
${ }^{43}$ Lax, op.cit., p.405.

${ }^{44}$ No original em italiano, o nome da ópera é L'elisir d'amore e o da ária "Una furtiva lagrima". Como essa ópera é a mais recorrente ao longo do filme deixaremos o título em português ao longo do trabalho.

${ }^{45}$ As citações do filme serão feitas em português, tradução minha a partir do original em inglês.
} 
Da forma como o prólogo é montado, podemos afirmar que a ópera comenta o discurso apresentado pela voz over. A ária escolhida por Allen reflete o momento em que Nemorino está "convencido de que influiu no ânimo de sua amada e que as coisas se encaminharão para bom porto" 46 , por conta do elixir:

[Nemorino]: [...] Un solo istante i palpiti / del suo bel cor sentir!.. / Co' suoi sospir confondere / per poco i miei sospir!... / Cielo, si può morir; / di più non chiedo. ${ }^{47}$

No entanto, diferentemente de Nemorino, que pensa ter sido agraciado pelo famoso elixir de Tristão, os espectadores sabem que o elixir de Dulcamara não passa de um vinho barato e que o real motivo para o sucesso repentino de Nemorino deve-se ao fato do jovem camponês ter se tornado o único herdeiro de um tio endinheirado. A sorte de Nemorino, no amor e nas finanças, advém da herança recebida, mas é atribuída ao elixir pelo personagem. A ópera ilustra o engano da aldeia e dos personagens e revela ao espectador que se trata de uma trapaça orquestrada por um charlatão.

Nesse sentido, ao utilizar o Elixir na abertura do filme, o mecanismo de identificação entre narrador e espectador é colocado à prova. Há uma desarticulação entre a imagem e a música como se fossem duas instâncias independentes. Ao contrário do princípio da música de acompanhamento, que orienta a prática hegemônica, na qual a fotografia, o diálogo, a atuação e a música caminham para um mesmo sentido. Em Match Point, cada um desses elementos aponta para uma direção. Em diversas ocasiões, a música e o comentário vão em direções opostas. A música comenta o discurso do protagonista, funcionando como uma espécie de aviso. Conforme procuraremos demonstrar, a utilização da ópera no filme incita o público a "colecionar detalhes" 48 .

Do contraste entre a ópera e os "pressupostos filosóficos" apresentados pela voz over no prólogo do filme, Allen passa a apresentação do protagonista. A ópera é interrompida pelo barulho de bolinhas de tênis e na cena seguinte não há menção à sorte. Se no prólogo a câmera posicionava-se no centro da rede e permanecia fixa; no segundo plano, o olhar da câmera acompanha os passos do protagonista Chris Wilton [Jonathan Rhys-Meyers], por meio

\footnotetext{
${ }^{46}$ Kobbé, op. cit., p.91.

${ }^{47}$ Donizetti, op.cit., p.92.

${ }^{48}$ Brecht, op. cit., p. 16.
} 
da utilização da câmera subjetiva. Assim, podemos afirmar que o espectador tem acesso à fachada do clube de tênis sob o olhar de Chris. No entanto, Allen apresenta primeiro a grade que separa as quadras de grama, o que confere certo distanciamento no plano da imagem em relação ao protagonista. Por trás da câmera, o protagonista caminha em direção a sede da construção vitoriana $^{49}$. Chris Wilton é apresentado de costas para o público; a câmera subjetiva segue os seus passos até a sede do clube. No momento em que Chris pára de caminhar, a câmera muda de posição e o focaliza. Ao fundo, o espectador observa alguns jogadores de tênis. Ainda sob o som das bolinhas, o personagem diz: "- Senhor Townsend" e dirige-se à entrada do edifício. A câmera não acompanha Chris, permanece no ambiente externo do clube, apresentando os sócios do estabelecimento que jogam tênis no local.

A cena é cortada de forma abrupta. Em seguida, não ouvimos mais o ruído das bolinhas de tênis que vinham acompanhando o percurso do protagonista, apenas a voz dos personagens no escritório de Sr. Townsend [Alexander Armstrong], localizado no interior do edifício - é possível observar pela janela do escritório, em profundidade de campo, os jogadores de tênis e as quadras de grama do estabelecimento. O Sr. Townsend conduz Chris ao escritório e elogia o currículo do jovem tenista. A cena, filmada em campo/contra-campo, revela que a contratação do protagonista pelo clube de tênis aristocrático deve-se à sua experiência ${ }^{50}$ :

[Sr. Townsend]: "Por aqui. Clube de Marbella, professor de tênis. Stanford House, Forte Village, Sardenha, Nice."

[Chris Wilton]: "Tenho bastante experiência."

[Sr. Townsend]: "Estou vendo. Ouvi muitos elogios. Não sente saudade do tênis profissional?".

\footnotetext{
49 Trata-se do régio Queen's Tennis Club: “Fundado em 1886, o Queen's Tennis Club foi o primeiro complexo poliesportivo construído no mundo. $\mathrm{O}$ clube foi nomeado em homenagem à Rainha Vitória, primeira patrona do estabelecimento e é mundialmente conhecido como uma das pioneiras quadras de grama. [...] Ao longo de sua história, o clube preserva um excepcional espaço desportivo e hoje sedia o mundialmente conhecido campeonato de AEGON [também chamado de torneio de Queen's] [...]. Suas quadras de grama estão entre as melhores do mundo. [...] É um dos clubes mais cobiçados do país". Disponível em: <http://www.queensclub.co.uk/site/_index nonmember.htm>. Acesso em: 6 jun.2009.

${ }^{50}$ Em sua análise sobre o ethos do capitalismo hoje, o sociólogo Osvaldo López-Ruiz comenta a respeito da importância do currículo em detrimento do diploma nas contrações: "Poucas dúvidas restam hoje de que a ênfase tenha mudado do diploma para o currículo. O que interessa ao mercado não é se as pessoas são proprietárias de um saber determinado, mas o conjunto de capacidades, habilidades e destrezas que elas possuem e como estas vêm sendo treinadas e desenvolvidas. Hoje, no mundo do capital humano, as pessoas são proprietárias de seus talentos (e responsáveis por manter/incrementar seu valor). O seu produto é fundamentalmente o que elas têm para vender no mercado, os seus talentos". Ver: López-Ruiz, Osvaldo Javier. Os executivos das transnacionais e o espírito do capitalismo. Capital humano e empreendedorismo como valores sociais. Rio de Janeiro: Azougue Editorial, 2007, p.273-274. A análise de López-Ruiz será retomada ao longo deste trabalho.
} 
[Chris Wilton]: "Graças a Deus não jogo mais. Eu odeio os torneios. Sempre viajando. E nunca seria Rusedski ou Agassi. É preciso muita vontade. Não que eu tenha o talento deles."

[Sr. Townsend]: "Seus títulos e referências são excelentes. E deseja morar em Londres?"

[Chris Wilton]: "Muito."

[Sr. Townsend]: "Somos um clube muito exclusivo. Pode começar neste fim de semana?"

[Chris Wilton]: "Obrigado. Muito obrigado."

Ao final desta cena, o espectador pode identificar que a voz over, apresentada no prólogo, era do protagonista Chris Wilton. Se por um lado, o foco narrativo se aproxima da perspectiva de Chris, por meio da utilização da câmera subjetiva, por outro, não é apenas o protagonista que fornece as informações necessárias ao espectador. No prólogo, a ópera comenta a ação e a imagem revela que, diferentemente do que afirmara Chris nos "pressupostos filosóficos", ele é contratado pelo aristocrático clube não por sorte, mas por apresentar um currículo compatível com o estabelecimento - "seus títulos e referências são excelentes", justifica o contratante Sr. Townsend. Chris jogou com grandes tenistas nos circuitos internacionais do esporte e foi instrutor de tênis em clubes de sócios privilegiados na Sardenha, Marbella, Nice, entre outros. Nesse sentido, assim como a ópera no prólogo, a contratação do tenista, baseada no currículo, relativiza o discurso da sorte proferido no início do filme.

Apesar da referência a alguns recursos que flertam com diversos dos procedimentos de um repertório de natureza épica em Match Point, é também preciso lembrar que a utilização da voz over, câmera subjetiva, profundidade de campo e campo/contra-campo nas primeiras cenas do filme pode ainda ser identificada como pertencente ao repertório do cinema clássico, o qual "alia a força de sedução da cena à invisibilidade do aparato" ${ }^{\text {. }}$. Assim, poderíamos afirmar que o espectador já está treinado aos padrões do cinema clássico, o que conferiria uma recepção padronizada do filme na qual o espectador "já está muito bem preparado antes mesmo de ver o filme, o enredo trata da trajetória de um indivíduo que sabe exatamente aonde quer chegar, há uma motivação realista que consiste em estabelecer conexões reconhecidas como plausíveis pela opinião comum, 'Um homem como este, naturalmente faria...",52. Desse modo, a montagem poderia parecer "invisível”: "Os cortes dos planos não têm outro objetivo que o de analisar o acontecimento segundo a lógica matemática ou dramática da cena. É sua

\footnotetext{
${ }^{51}$ Xavier, Ismail. O olhar e a cena: melodrama, Hollywood, Cinema Novo. São Paulo: Cosac Naify, 2003 , p. 57.

${ }^{52}$ Bordwell, op. cit., p.164.
} 
lógica que torna tal análise insensível; o espírito do espectador adota naturalmente os pontos de vista que o diretor lhe propõe, pois são justificados pela geografia da ação ou pelo deslocamento do interesse dramático."

Todavia, se é possível argumentar que o filme trabalha com o repertório do cinema clássico, a hipótese do trabalho entende que a obra apresenta uma discussão sobre o próprio cinema, expondo o mecanismo e enfatizando o caráter da obra reflexiva. A pretensa "naturalidade" com que o espectador acompanha os passos do protagonista torna-se material do filme. Match Point tratará justamente da "naturalidade" das ações e da ideologia que são as diretrizes do protagonista. Se aceitarmos o discurso de Chris, entenderemos cada cena do filme como sorte. No entanto, como será exposto a seguir, a utilização da música, a montagem, as locações escolhidas e o diálogo entre os personagens questionam o discurso da sorte e revelam o arrivismo do protagonista.

No momento da contratação de Chris pelo clube de tênis, o espectador tem acesso às excelentes referências, à boa aparência e ao tom modesto do protagonista ("Eu nunca seria Rusedski ou Agassi. É preciso muita vontade. Não que eu tenha o talento deles"), o que deslegitima o discurso da sorte. A locação escolhida por Allen revela a classe social a qual Chris pretende associar-se, ou seja, a escolha do local $^{54}$ também não pode ser atribuída ao acaso. Ao espectador inglês e aos fãs de tênis não passa despercebido o clube sede do famoso torneio homônimo que precede Wimbledon. O espectador é, portanto, convidado a acompanhar a narrativa sob o olhar de Chris. Todavia, existem recursos de distanciamento que permitem questionar o estatuto do narrador. Novamente se estabelece uma tensão entre o discurso da sorte e a escolha do protagonista que nada deve ao acaso.

Outro indício de que o filme distancia-se do protagonista pode ser observado por meio do uso da montagem que caracterizará o estilo de momentos importantes do filme. Na cena seguinte à contratação de Chris podemos observar essa tendência. O filme apresenta o dormitório do protagonista, situando o espectador em um local bastante diverso do régio

\footnotetext{
${ }^{53}$ Bazin, André. O cinema (1985) - trad. Eloísa de Araújo Ribeiro. São Paulo: Brasiliense, 1991, p.67.

${ }^{54} \mathrm{O}$ Queen's Tennis Club pode ser reconhecido pelo público. Ver a caracterização do protagonista de Match Point feita por Philip French: "O personagem principal é Chris Wilton, um tenista irlandês de origens humildes que decidiu abandonar os torneios (nos quais teve pouco prestígio) para se tornar professor de tênis no clube exclusivo Queen's, em Londres." Disponível em: 〈http://www.guardian.co.uk/film/2006/jan/08/review.features7>. Acesso em: 13jan. 2010. E a identificação do local feita por Colin Cameron: "se a viagem for rápida, você deve pular o clube Queen's, sede do torneio de tênis que precede Wimbledon e local da cena de abertura". Disponível em: $\langle$ http://travel2.nytimes.com/2006/02/07/travel/08weblondon.html〉. Acesso em: 13 jan. 2010.
} 
Queen's Tennis Club. Observa-se uma caçamba com entulhos, carros estacionados e um caminhão cruzando a rua. Ao fundo, um edifício antecipa o espaço no qual a câmera adentrará: ouve-se o barulho dos veículos e uma voz indeterminada, mas com sotaque cockney apresentando o novo espaço: "Este é o seu sofá, que também vira cama.” A indicação do sotaque do corretor de imóveis indica a famosa ênfase que os ingleses colocam na enorme variedade de sotaques de sua língua. Na Inglaterra, a pronúncia marca a distinção de classe ${ }^{55}$.

Diferentemente da ópera e do ruído das bolinhas de tênis das cenas anteriores, ouvimos o barulho do trânsito e observamos a fachada de um prédio - provavelmente situado na parte leste de Londres e não em West Kensington como o Queen's. Trata-se da residência de Chris, o que revela que o professor não pertence ao mundo aristocrático de seus alunos. Depois da apresentação da fachada do edifício, há um novo corte e o olhar da câmera focaliza o sofá no apartamento, ainda sem que vejamos os personagens. Ao passo que olhamos para o pequeno sofá, a voz do corretor de imóveis, fora do campo visual, expõe os motivos para a locação: “O que é ótimo, sabe, por que você pode assistir tevê e não vai ter que ter uma trabalheira para ir ao quarto. Você só abre o sofá cama e tira a sua soneca."

Filmada em câmera circular, a cena permite que se observem os objetos do cômodo: o sofá, um pequeno móvel, algumas cadeiras, um aquecedor, alguns quadros. Em seguida, Chris e o corretor de imóveis [Paul Kaye] aparecem de costas para o público, a voz que estava fora do campo visual é identificada como sendo a do corretor: "A cozinha é logo ali. Todos os utensílios domésticos, máquina de lavar, todas essas coisas. Linda vista, sem nada na sua frente. É simplesmente perfeito." O uso da câmera circular nesta cena também permite que o espectador tenha a exata sensação da pequenez do local, o que contrasta decididamente com a cena anterior do amplo clube de tênis.

A despeito do protagonista (cujo sotaque diferencia-se do corretor e assemelha-se ao dos sócios do Queen's), o filme aproxima Chris do corretor de imóveis. Perante a apresentação, feita pelo corretor, de que o apartamento seria "simplesmente perfeito", Chris indaga: "E são 225 libras por semana?”. O corretor vai direto ao ponto: “Claro, cara, estamos em Londres. Se você não gostou, mude para Leeds. Entendeu?”. O diálogo, portanto, indica o poder aquisitivo de Chris, muito mais próximo ao do corretor do que ao da classe que almeja se aproximar. Ao

\footnotetext{
${ }^{55}$ Diferentemente de Chris que imita o sotaque de seus alunos abastados, o corretor de imóveis tem um sotaque cockney. O tipo de sotaque é descrito como "o jeito de falar inglês típico das classes trabalhadoras na parte leste de Londres". Disponível em: <http://www.ldoceonline.com/dictionary/cockney>. Acesso em: 6 fev. 2010.
} 
estabelecer a comparação entre os preços do aluguel de apartamentos em Londres e os de Leeds (cidade industrial situada no norte da Inglaterra), o corretor de imóveis trata com escárnio o irlandês.

A cena é cortada para um bar estreito e escuro, onde Chris faz uma refeição e lê notícias de um jornal. Há um novo corte rápido e novamente ouvimos o som de bolinhas de tênis no Queen's Tennis Club onde os jogadores rebatem as bolinhas. A técnica do campo/contracampo é utilizada aqui para mostrar o trabalho mecânico de Chris, o entusiasmo do jovem tenista durante a entrevista de emprego, filmada com a mesma técnica, contrasta com o tédio durante as aulas de tênis. Posicionado do lado direito da quadra, Chris rebate as bolinhas para seus alunos e a cada batida do professor um jogador diferente aparece na tela, no lado esquerdo da quadra. O espectador acompanha os diversos alunos de Chris - primeiro, uma mulher jovem; depois, um homem de meia-idade; a terceira, uma senhora - o que indica a passagem do tempo e o caráter repetitivo do trabalho do professor de tênis.

Da exposição do aspecto mecânico do trabalho do protagonista, Allen retorna ao apartamento de Chris. O professor de tênis está deitado no sofá do seu dormitório, já apresentado anteriormente. Observa-se, em primeiro plano, a capa do romance Crime $e$ Castigo, de Fiódor Dostoievski. Pode-se observar em primeiro plano a edição do livro: tratase da popular coleção Penguin Classics. O tédio torna a caracterizar o protagonista, ouve-se um bocejo de Chris e, em seguida, ele troca o romance russo pela coletânea de ensaios Cambridge Companion to Dostoievski, a qual o protagonista parece interessar-se mais. À primeira vista, a cena pode parecer sem importância, mas ela revela a predileção do protagonista pelos comentários sobre os autores clássicos em detrimento da leitura integral do romance. O acerto da "estratégia" empregada será revelado mais tarde.

Do ponto de vista de um encadeamento estritamente dramático, a apresentação do dormitório de Chris feita pelo corretor de imóveis, a refeição na lanchonete e a troca de livros não são essenciais à configuração do enredo. A exposição da trajetória ascendente de Chris Wilton não precisaria das cenas mencionadas. No entanto, elas são essenciais justamente por não corroborar a ação. Assim como a utilização da música extra-diegética poderia ser dispensada caso o diretor quisesse apenas contar a trajetória do protagonista, as cenas apresentadas acima poderiam ser descartadas por Allen. Porém, elas devem ser entendidas como recursos de distanciamento em relação ao protagonista. 
A cena da troca de livros é seguida por um novo corte, restabelecendo no centro da ação o Queen's Tennis Club. No clube de tênis, o caráter repetitivo do trabalho de Chris é ressaltado. Na apresentação de Chris, as cenas do trabalho são intercaladas com a do aluguel e a da troca de livros. Allen monta o filme de forma que a leitura do Cambridge Companion possa estar configurada como estratégia do protagonista para a ascensão social, conforme mostraremos a seguir. Observa-se o Sr. Townsend e um jovem tenista aproximarem-se da câmera. O patrão de Chris apresenta-o a seu novo aluno:

[Sr. Townsend]:"Chris Wilton, este é Tom Hewett."

[Tom Hewett]: "Muito prazer em conhecê-lo."

[Sr. Townsend]: "Eu acho que o Chris vai ser um instrutor perfeito para você, ele é muito paciente. Ótimo em analisar as falhas dos jogadores."

[Tom Hewett]: "Estou tão fora de forma. Eu não jogo desde a faculdade, e eu adorava, mas não pego numa raquete há séculos."

[Chris Wilton]: "Não se preocupe, isso volta. O que você não pode fazer é se apressar, ficar desanimado."

[Sr. Townsend]: "Ok. Bem, boa sorte."

[Tom Hewett]: "Muito obrigado".

[Chris Wilton]: "Por aqui."

[Tom Hewett]: "Ótimo".

Diferentemente dos alunos anteriores, Tom Hewett [Matthew Goode] é apresentado ao protagonista por intermédio de Sr. Townsend, o que indica tratar-se de um aluno que se destaca entre os ricos. O chefe de Chris não poupa elogios ao professor: "Eu acho que o Chris vai ser um instrutor perfeito para você, ele é muito paciente. Ótimo em analisar as falhas dos jogadores." A informação de que Chris é um bom analista "das falhas dos jogadores" é um detalhe a ser guardado pelo espectador, pois antecipa características de Chris como jogador que serão expostas nas cenas subsequentes.

Em seguida, observa-se o jogo entre professor e aluno. Todavia, desta vez, após a aula de tênis, Chris e Tom conversam enquanto tomam refrescos em uma mesa de bar no clube . A cena é filmada em profundidade de campo, professor e aluno estão no edifício vitoriano, onde Chris, outrora, restringia-se apenas ao espaço das quadras de tênis, local em que dá aulas aos sócios do Queen's. Durante o diálogo entre Tom e Chris, vê-se que o jovem Hewett interessase pelo professor de tênis por conta de sua experiência no circuito internacional de tênis (característica que fora sublinhada por Sr. Townsend no momento da contratação do protagonista): 

Agassi?"

[Tom Hewett]: “Ok, quem é melhor, ou mais difícil: Henman ou

[Chris Wilton]: "Os dois eram ótimos."

[Tom Hewett]: "Sim, eu sei. Mas você enfrentou os dois com classe."

[Chris Wilton]: "Por um tempo. Mas, conforme o jogo continua você vê como eles são bons."

Durante a conversa entre Tom Hewett e seu instrutor, o fato de que Chris jogou com um dos melhores tenistas do mundo, o norte-americano Andre Agassi (ganhador de oito títulos de torneios Grand Slam e famoso por sua imagem publicitária), mas também com Tim Henman $^{56}$, jogador que foi aclamado pela mídia inglesa como a grande "esperança britânica"57 revelam que o instrutor de tênis foi selecionado por conta de sua elevada experiência técnica, mas também por conta de sua inserção no circuito de tênis como evento midiático, pois tanto o norte-americano como o britânico são bons exemplos das relações entre o tênis e o showbusiness.

A habilidade do protagonista em impressionar não se dá apenas pela experiência em competições internacionais de tênis: Chris também causa boa impressão pela cortesia para com seus alunos abastados, trata-se de alguém que, entre os ricos, "conhece o seu lugar". Da forma como Allen monta a cena, o espectador poderá notar a carteira de Tom ao lado do jovem Hewett. $\mathrm{O}$ garçom do estabelecimento passa em frente à câmera e deixa a conta ao lado do sócio do clube. Chris tenta pagar a conta de maneira educada, mas é impedido pelo aluno:

[Chris Wilton]: "Eu pago essa. Não, por favor, Tom, eu insisto." [Tom Hewett]: "Não, não. Tire o seu forehand poderoso daqui." [Chris Wilton]: "Obrigado. Eu pago a próxima."

$\mathrm{Na}$ cena que poderia apenas ilustrar uma inocente conversa entre professor e aluno, configura-se mais uma peça do enxadrismo de Allen. A montagem feita pelo cineasta permite ao espectador estabelecer relações entre a troca do romance Crime e Castigo pela coletânea de

\footnotetext{
${ }^{56}$ Ver a sessão rankings e prêmios dos tenistas Andre Agassi e Tim Henman na Associação de Tenistas Profissionais (ATP). Disponível em: <http://www.atpworldtour.com/Tennis/Players/He/T/TimHenman.aspx?t=tf $>$ e 〈http://www.atpworldtour.com/Tennis/Players/Ag/A/Andre-Agassi.aspx?t=tf $>$. Acesso em: 13 jan.2010.

${ }^{57}$ Aclamado pela mídia e pela rainha Elizabeth II, que concedeu ao tenista o prêmio de Officer of Order of British Empire, Henman nunca ganhou um Grand Slam.
} 
textos sobre Dostoievski e a cena seguinte em que o interesse por outro clássico da cultura burguesa, a ópera, aproxima o instrutor de tênis ao aluno endinheirado:

[Tom Hewett]: "Você quer uma carona?"

[Chris Wilton]: "Na verdade, eu estou procurando uma loja de música. Quero comprar uns CDs." Road."

[Tom Hewett]: "Música por aqui? Eu acho que tem uma na Fulham

[Chris Wilton]: "E eles têm uma sessão digna de ópera?"

[Tom Hewett]: "Ópera? Você gosta de ópera, verdade?"

[Chris Wilton]: "Eu amo ópera."

[Tom Hewett]: "Papai doa toneladas de dinheiro para o Royal, em Convent Garden. Sei que isto vai parecer meio estranho, mas quer ir à ópera amanhã à noite?"

[Chris Wilton]: "À ópera?"

[Tom Hewett]: "A gente tem um camarote e uma pessoa não vai. Será a Traviata."

[Chris Wilton]: "Meus Deus, eu adoraria. Você tem certeza de que não vou atrapalhar? Posso ao menos pagar pelo meu lugar?"

[Tom Hewett]: "Não vai atrapalhar, será um prazer. Eu só gosto do fato de que ambos amamos ópera. Ótimo."

A experiência de Chris no circuito internacional de tênis, aliada ao gosto do protagonista por literatura e ópera estreitam os laços entre o irlandês e seus alunos ingleses milionários. $\mathrm{O}$ tênis - que conta com um circuito que sempre esteve ligado ao dinheiro, às grandes premiações, ao público abastado que frequenta os eventos, aos clubes de sócios privilegiados, etc. - configura-se para o protagonista como uma habilidade que permite acesso ao mundo dos ricos. Além de ter jogado com os famosos e melhores tenistas, enfrentando-os "com classe", Chris adora ópera, característica que aproxima ainda mais Tom Hewett de seu professor.

Neste ponto, a ópera retorna ao filme como referência diegética e estratégia para a ascensão social do protagonista. Após esta indicação de que o gosto de Chris por ópera agradou Tom, Allen corta imediatamente para a fachada do Royal Opera House ${ }^{58}$. Em seguida, o espectador é levado ao camarote dos Hewett, no qual estão os pais de Tom, Alec [Brian Cox] e Eleanor [Penelope Wilton], e a irmã, Chloe [Emily Mortimer] em primeiro

\footnotetext{
${ }^{58}$ Localizado em Convent Garden, o Royal Opera House é o mais famoso teatro londrino. A primeira apresentação no local que se tem registro data de 1735. Em 1808, o edifício foi completamente destruído por um incêndio, desde então, o teatro passou por inúmeras reformas. A fachada apresentada em Match Point integra a construção antiga do teatro. Disponível em: $\langle$ http://www.roh.org.uk/discover/royaloperahouse/history.aspx $>$. Acesso em: 6 jun. 2009.
} 
plano. Ao fundo podem-se observar os outros camarotes do teatro. Chris chega acompanhado por Tom. O primeiro a cumprimentá-lo é o patriarca, que afirma ter ouvido dizer que Chris "é um ótimo tenista".

A ópera, que já havia aparecido no prólogo do filme como música extra-diegética, retorna como conteúdo da conversa entre Tom e Chris e reaparece como música diegética enquanto os Hewett e Chris assistem à apresentação de La Traviata ${ }^{59}$. O trecho apresentado no filme é cantado por Alfredo, no qual o personagem declara seu amor pela cortesã Violeta (a traviata do título). A "transviada" do filme está ausente da cena - Nola ainda não fora apresentada a Chris -, mas o filme antecipa o desenvolvimento da ação ao incluir a personagem por meio da música extra-diegética: a presença de Nola é marcada pela sua ausência. Se no plano da ópera, o jovem rico Alfredo revela que está apaixonado pela prostituta Violeta, no filme, Allen apresentará o descaso de Tom por sua namorada, que pode ser associada à transviada Violeta. Nola é a "pessoa que não virá à ópera" e que dá lugar no camarote dos Hewett ao tenista irlandês. Desse modo, desde a primeira menção à jovem atriz, ela tem suas chances de entrada na família reduzidas quando comparadas às do protagonista.

$\mathrm{Na}$ ária apresentada no filme, as palavras "Di quell'amor ch'è palpito" parecem indicar "o efeito que surte nela [Violeta] o amor sincero de Alfredo" 60 , o que contrasta com a ação do filme em que o jovem Hewett despreza a namorada e Chris tenta conquistar a família endinheirada. Outro indício da oposição entre a ópera e a imagem dar-se-á pela sugestão do interesse da irmã de Tom pelo tenista. O "dia feliz etéreo" pode ser entendido como o sucesso do arrivista que causa boa impressão na família Hewett e desperta o interesse da jovem herdeira. A interrupção brusca da ária de La Traviata relativiza o discurso proferido pelo protagonista, assim como no caso de O Elixir de Amor, apresentado no prólogo do filme. A cena termina com Alfredo dizendo ser "misterioso" esse amor por Violeta. Ao invés de trazer continuidade ao desenvolvimento da narrativa, o uso da ópera no filme faz com que "não fiquemos muito identificados e nos mantenhamos distanciados em face dos personagens e de seus desastres"

\footnotetext{
${ }^{59}$ La Traviata é interpretada pela companhia Slovak Radio Symphony Orchestra and Chrorus. Podemos observar que o uso de óperas no filme não é nada casual, as óperas comentam a ação. As gravações presentes no filme são ou de apresentações antigas, cantadas por Enrico Caruso, ou interpretadas pela companhia eslovaca, contratada por Allen para interpretar árias específicas para o filme.

${ }^{60}$ Kobbé, op. cit., p. 326.

${ }^{61}$ Rosenfeld, op.cit., p.157.
} 
A montagem destas cenas - primeiro, a conversa entre professor e aluno no clube de tênis, onde o protagonista manifesta o seu interesse por ópera e em seguida é convidado para o camarote dos Hewett; depois, a apresentação de La Traviata no Royal Opera House, ocasião em que Chris conhece os pais e a irmã de Tom; e por último, o convite para a casa de campo - demonstram a rápida aproximação entre o jovem professor de tênis e a elite britânica. Na cena seguinte à apresentação da ópera La Traviata, Tom comenta a boa impressão que Chris causou nos Hewett. Em seu escritório, composto por mobília antiga, livros, pinturas a óleo, jornais, papéis, agendas, telefones e um computador, o jovem milionário relata a Chris que Alec e Eleanor adoraram as flores enviadas pelo protagonista em agradecimento ao convite para a ópera. No diálogo entre camaradas pelo telefone, Tom diz que, apesar de "desnecessário", Chris fez muito bem em enviar as flores: "Meus pais adoram esse tipo de coisa". Na cena fica evidente que Chris agradou a família e que é convidado para o fim de semana na casa de campo por conta da boa impressão que os pais e a irmã de Tom tiveram a respeito de Chris. A finesse do jovem tenista irlandês prossegue na cena seguinte em que o protagonista joga com Tom na casa de campo em Hedley ${ }^{62}$. Chris passou da quadra de tênis do Queen's, onde é professor, para a visita à casa de campo de um dos sócios do clube. Durante o jogo no Englefield Estate ${ }^{63}$, Tom desiste da partida de tênis e pede para que a irmã o substitua:

\footnotetext{
${ }^{62}$ Os personagens de Match Point referem-se à casa de campo apresentada no filme como Hedley. A cidade Hedley não existe, no entanto a casa de campo apresentada no filme é bastante conhecida: trata-se do Englefield Estate, localizado no condado de Berkshire. O nome Englefield significa Englishmen's (Battle) Field, ou seja, campo de batalha dos ingleses. "A casa de campo foi residência da família Englefield desde o reinado de Edgar, o "pacificador", no início do século IX. Embora Sir Francis Englefield tenha se esforçado para manter a casa, depois de quase 800 anos de residência, a família foi forçada a deixar a propriedade, em 1550, devido à sua crença no catolicismo. Eles, no entanto, permaneceram fiéis à sua antiga casa e continuaram a ser enterrados na Capela de Englefield, até 1822. A casa passou pelas mãos de diversos não-residentes, depois da saída dos Englefield, embora o conde e a condessa de Essex parecessem ter um interesse nela. Em 1635, o genro da condessa, Marquês de Winchester, comprou a propriedade e foi em Englefield que ele se aposentou, após o seu retorno do exílio durante o Commonwealth. Os descendentes do Marquês, os Powlets e os Wrights, continuaram a viver na residência durante os séculos XVII e XVIII, até que a casa passou, por casamento, à família Benyon, seus atuais proprietários." Conforme verbete "Englefield House" na Enciclopédia Britânica. Disponível em: $\langle$ http://www.britannia.com/history/chouses/berks/englefieldhse.html $>$. Acesso em: 13 jan, 2010.

${ }^{63} \mathrm{Em} O$ campo e a cidade, Raymond Williams analisa, entre outros aspectos que serão retomados ao longo deste trabalho, a importância da mansão senhorial: "Neste ponto, contudo, normalmente constatamos que os iniciadores dos melhoramentos, os comandantes das transformações, já chegaram há mais tempo e estabeleceram raízes mais profundas - já realizaram uma divisão bem-sucedida em proveito próprio. A mansão senhorial [...] foi uma das primeiras formas que esta solução temporária assumiu, e, no século XIX, ao mesmo tempo que os novos senhores da produção capitalista construíam mansões novas, recuperava-se igual número de mansões antigas, outrora dos antigos senhores - por vezes ancestrais dos novos - da velha ordem rural". Ver: Williams, Raymond. O campo e a cidade: na história e na literatura / Raymond Williams; trad. Paulo Henriques Britto. São Paulo: Companhia das Letras, 1989, p 393.
} 
[Tom Hewett]: "Chlo-Chlo, você quer jogar com o Chris? São 5 horas da tarde e eu tenho que começar a fazer uns coquetéis. Irlandês, você já provou cuba libre ou caipirinha?"

[Chloe Hewett]: "Chris ficaria muito entediado se jogasse comigo."

[Tom Hewett]: "É tedioso jogar comigo, mas ele é um bom esportista. De qualquer forma, você tem pernas melhores do que as minhas. Vamos, vamos!"

[Chris Wilton]: "Não seja boba. Ensino pessoas que nunca tiveram uma raquete antes."

[Chloe Hewett]: "Eu sou tão ruim."

[Chris Wilton]: "Mas, é assim que evolui, jogando com um jogador melhor. Vamos."

[Chloe Hewett]: "Está bem."

Tom marca a origem social do protagonista ao chamar seu professor de irlandês. Por estar perdendo o jogo e não conseguir acompanhar o ritmo do tenista, Tom desiste da partida. Todavia, ele não abandona o jogo sem antes provocar o irlandês: "Você já provou cuba libre ou caipirinha?" A origem social do protagonista, combinada à oferta de famosos coquetéis, de certa forma, retoma o preconceito e conflito histórico entre Inglaterra e Irlanda, no qual persiste a ideia de que os irlandeses seriam "grosseiros e bêbados" ${ }^{\text {"64 }}$. Se por um lado a fala de Tom por sua grosseria "desmascara a própria civilidade britânica",65, por outro, ela mostra que Tom sabe que Chris quer impressionar a família, comportando-se de maneira apropriada.

O anúncio de que Chris é irlandês contribui para as informações as quais o espectador tem acesso a respeito do protagonista. Na quadra de tênis da casa de campo, Tom repassa a raquete à irmã. Os irmãos aparecem separados do professor por meio de uma grade. $\mathrm{O}$ olhar da câmera não acompanha o protagonista, mas observa a jovem inglesa durante o jogo. A maneira de jogar de Chloe assemelha-se a dos outros alunos de Chris no Queen's. Nesse ponto, Chris, que fora convidado para o fim de semana na casa de campo e que tenta comportar-se como um convidado dos Hewett, aparece como professor de tênis. Tanto no Queen's quanto no Englefield Estate, ele está trabalhando.

\footnotetext{
64 "Para o irlandês, a aguardente é a única coisa que dá sentido à vida; a aguardente e, claro, o seu temperamento desleixado e jovial: eis por que se entrega à bebida até a mais completa embriaguez. $\mathrm{O}$ caráter meridional, frívolo, do irlandês, a sua grosseria, que o coloca a um nível pouco superior ao do selvagem, o seu desprezo por todos os prazeres mais humanos, que é incapaz de experimentar precisamente devido à sua rudez, sujeira $\mathrm{e}$ pobreza, são outras razões que favorecem o alcoolismo." Ver: Engels, Friedrich, 1820-1895. A situação da classe trabalhadora na Inglaterra./ Engels; trad. Rosa Camargo Artigas, Reginaldo Forti. São Paulo: Global, 1985, p.111-112.

${ }^{65}$ Eagleton, Terry. Heathcliff and the Great Hunger - Studies in Irish Culture. London: Verso, 1995, p.9.
} 
No plano do enredo, o jogo de tênis serve para aproximar Chloe e Chris. Ao final do jogo, o professor a elogia: "Você tem um estilo único". Sabendo que o elogio é descabido, a jovem nega a lisonja: "Claro, chama-se desastrado". Por trás das árvores da propriedade, a câmera distancia-se do casal. A irmã de Tom pergunta sobre a habilidade técnica do tenista irlandês: "Afinal, como você conseguiu ser tão bom? Tom me disse que você jogou com os melhores.". O protagonista retoma na resposta à jovem herdeira sua origem social: "foi um jeito de sair da existência pobre. Atraí a atenção de um bom treinador. Não sei. No começo foi tão fácil”. Apesar da destreza como esportista, o protagonista revela que não gosta de ser professor: "Por ora está bom, mas eu me mataria se tivesse que fazer isso para sempre. Gostaria de fazer algo da minha vida, sabe? Algo especial. Queria dar uma contribuição.”

Neste ponto, da aproximação entre a jovem inglesa rica e o irlandês, o filme reverte uma relação histórica, cuja melhor formulação na cultura britânica é aquela do romance $O$ morro dos ventos uivantes (1847), de Emily Brontë. Na primorosa análise do romance feita por Terry Eagleton, a caracterização de Heathcliff como "sujo, áspero, selvagem e demoníaco"66 seria uma maneira de falar dos ingleses típica para caracterizar os irlandeses. A contrapelo da ideia do "romance eterno" entre Heathcliff e Cathy, Eagleton argumenta que “(...) a história, a propriedade e o poder são os responsáveis pelo encontro entre Catherine Earnshaw e Heathcliff, não o sagrado amor matrimonial ou o afeto filial" ${ }^{\text {"67 }}$. A história de luta entre irlandeses e ingleses e o interesse pela propriedade e pelo poder aproxima, portanto, Heathcliff de Chris Wilton (conforme procuraremos demonstrar a seguir). De certa maneira, Heathcliff preserva a diferença e se revela como a face mais violenta da dominação, entre outros aspectos. Por sua vez, neste ponto do filme, Chris imita a classe dominante, tenta vestir-se como Tom, ler os clássicos, apreciar ópera, frequentar galerias de arte, etc. Um dos momentos no qual Chris, assim como Heathcliff tenta esconder suas origens, ocorre quando ele pede licença à herdeira para trocar de roupa: "os seus convidados não devem estar esperando um tenista suado", buscando retirar qualquer vestígio que esteja relacionado ao seu trabalho como empregado dos ingleses ricos. Chris busca não aparentar suas origens: ele fala pouco e apenas quando lhe perguntam sobre a sua vida na Irlanda, não tem sotaque irlandês, trabalha para os ingleses ricos e imita o gosto dos seus alunos abastados. - Chris é apresentado à família e convidado para o fim de semana na casa de campo.

\footnotetext{
${ }^{66}$ Eagleton, op.cit., p.3.

${ }^{67}$ Ibid., p. 18.
} 
Depois da conversa com a jovem herdeira, Allen corta para um plano geral dos jardins da casa de campo onde estão os outros convidados dos Hewett. Chris não está entre os amigos da família que conversam no local, o que revela que seu convívio, por enquanto, está restrito aos irmãos Hewett e à quadra de tênis, situada nos fundos da residência. A introdução da cena no filme marca a ausência do protagonista. Novamente, a obra vai além do olhar do protagonista, pois o espectador não tem acesso apenas ao que Chris vê. Na cena dos jardins da residência, Allen introduz outra música extra-diegética, a ópera Il Trovatore ${ }^{68}$, de Giuseppe Verdi:

[Manrico]: "Mal reggendo all'aspro assalto,/ Ei già tocco il suolo avea: / Balenava il colpo in alto / Che trafiggerlo dovea... / Quando arresta un moto arcano, [...]"

A introdução da ópera no filme oferece outro elemento ao espectador que antecipa a ação. O trecho da ópera selecionado por Allen apresenta o momento em que Manrico explica por que poupou no duelo a vida do conde de Luna: o trovador afirma "ter ouvido uma voz dizer-lhe para que poupasse o adversário, no momento em que se preparava para golpeá-lo"69. Se na ópera há um "assalto amargo" contra o conde, no filme a imagem revela o seu oposto, ou seja, o fascínio do protagonista pela aristocracia. Tanto o emprego no famoso clube de tênis quanto o convite para a apresentação de ópera, o interesse de Chloe pelo protagonista, as flores enviadas por Chris à família e o fim de semana na casa de campo são indícios de que Chris não tentará golpear o conde, mas aliar-se a ele.

Desse modo, a introdução da ária "Mall reggendo all'aspro assalto" não entra criando identificação entre o personagem e a música, ou seja, corroborando a trajetória de Chris; ela ressalta o contraste entre a revolta contra o conde e a aliança com a família Hewett. No plano

\footnotetext{
${ }^{68}$ A ópera trata da vingança de Azucena, filha de uma velha cigana que foi queimada viva por ter sido acusada de ter enfeitiçado o filho mais novo do conde de Luna. Azucena seqüestra o filho do conde com a intenção de atirá-lo às chamas da fogueira. Ainda transtornada pela morte da mãe, no entanto, ela lança ao fogo seu próprio filho. Decide então criar o filho do conde - Manrico, o trovador - como se fosse seu, na esperança de um dia vingar sua mãe através dele. Ao começar a ópera, Manrico já é adulto, Azucena está envelhecida, o velho conde morreu e seu filho mais velho - o conde de Luna - é seu único herdeiro. O conde quer ver capturado o misterioso trovador que tem feito serenatas à duquesa Leonora, objeto de sua paixão não correspondida. O conde e Manrico duelam por Leonora, mas o trovador poupa a vida do conde. Na tentativa de salvar Azucena, Manrico acaba capturado pelo conde. Para libertar o trovador, Leonora promete casar-se com o conde, no entanto, ela traz no dedo um anel com veneno, que ingerirá uma vez libertado Manrico. Leonora morre nos braços do trovador, o conde de Luna encontra-os e ordena que Manrico seja morto. Após a morte do trovador, Azucena revela ao conde que Manrico era seu irmão. Ver Kobbé, op.cit. p.321-325.

${ }^{69}$ Ibid., p.323.
} 
da imagem, a câmera acompanha o percurso do protagonista que, vestido apropriadamente para o encontro com os convidados dos Hewett, desce as escadas ${ }^{70}$ da residência (cena que será recorrente no filme) admirado com os pertences da família: ele observa as pinturas a óleo dos ancestrais da família, as partituras, as porcelanas antigas e a biblioteca magnífica, percurso que salienta a base material da aliança. Ao sair da biblioteca, o barulho de bolinhas de pingue-pongue se sobrepõe à ópera. Chris caminha em direção ao ruído que é cada vez mais nítido; a ópera é interrompida no verso "Che trafiggerlo dovea..."71, Allen corta a cena e apresenta o início do "golpe", que não será contra o conde. A ópera antecipa o duelo entre irmãos que se seguirá no filme.

\title{
1.2 Apresentação de Nola Rice
}

\begin{abstract}
"É o lugar do olhar e a possibilidade de variá-lo e de expô-lo que definem o cinema. [...] Ultrapassando o simples realce da qualidade de ser olhada, oferecida pela mulher, o cinema constrói o modo pelo qual ela deve ser olhada, dentro do próprio espetáculo. Jogando com a tensão existente entre o filme enquanto controle da dimensão do tempo (montagem, narrativa), e o filme enquanto controle das dimensões do espaço (mudanças de distância, montagem), os códigos cinematográficos criam um olhar, um mundo e um objeto, de tal forma a produzir uma ilusão talhada à medida do desejo. São estes códigos cinematográficos e sua relação com as estruturas formativas externas que devem ser destruídos no cinema dominante, assim como o prazer que ele oferece deve também ser desafiado."
\end{abstract}

Laura Mulvey, Prazer visual e cinema narrativo.

Em contraponto a Chris, a antagonista é apresentada por meio de uma rima visual com a cena de abertura do filme. Assim como o protagonista, Nola [Scarlett Johansson] aparece como uma jogadora entre os Hewett, separada dos outros convidados, porém, aceita por seus dotes físicos e sua inserção no showbusiness. No momento da entrada de Nola, o filme que

\footnotetext{
70 " $\mathrm{Na}$ verdade, a forma atual da casa e sua decoração não são muito diferentes do que pode ser visto na pintura de John Constable, de 1832, ou no segundo plano do retrato de Powl Wrighte, por volta de 1775. Englefield é uma casa elisabetana, cuja planta sofreu remodelações nos séculos XVIII e XIX, sem nunca sofrer nenhuma drástica alteração em seu plano básico ou no estilo de sua fachada externa. [...] Sem dúvida, a maior parte do mobiliário, armários e porcelanas que iluminam a casa hoje foram trazidos do Oriente [...]. Elementos decorativos deste período sobrevivem na sala para fumantes, na sala de jantar e na sala de estar, mas a identidade do arquiteto responsável permanece incerta. [...] O teto da biblioteca e a ideia de uma escadaria imperial em Englefield (1775) são realizações suficientes para fazer crer que o arquiteto James Wyatt foi, pelo menos, consultado". Disponível em: <http://www.englefieldestate.co.uk/>. Acesso em: 6 jun. 2009.

${ }^{71} \mathrm{O}$ momento em que Manrico explica por que não esfaqueou o conde de Luna: "Quando fui esfaqueá-lo...". A voz que Manrico escuta impede o trovador de matar o irmão.
} 
outrora demonstrara a cortesia do professor irlandês, agora, apresenta a brutalidade para com a semelhante. A disputa, portanto, conforme antecipara a ópera Il Trovatore, dar-se-á entre irmãos. Nola e Chris reconhecem-se na casa de campo: eles são jogadores, estrangeiros e pobres em relação aos Hewett. Conforme procuraremos demonstrar ao longo da análise do filme, apesar da semelhança física ${ }^{72}$, acentuada pela maneira como Allen apresenta-os e da correspondência de classe, conserva-se a mulher como imagem, o homem como o dono do olhar, conforme a famosa formulação de Laura Mulvey a respeito do prazer visual no cinema narrativo, na qual se tem: "Um desequilíbrio sexual, o prazer no olhar foi dividido entre ativo/masculino e passivo/feminino. $\mathrm{O}$ olhar masculino determinante projeta sua fantasia na figura feminina, estilizada de acordo com essa fantasia",73.

A cena da apresentação de Nola dialoga com a maneira tradicional de representação da mulher no cinema narrativo, na qual "o olhar masculino determinante projeta sua fantasia na figura feminina, estilizada de acordo com essa fantasia" ${ }^{\text {74 }}$. Até mesmo a escolha da atriz, eleita diversas vezes entre as mais belas, corrobora para a caracterização de Nola como objeto do desejo masculino. A personagem preenche o papel feminino tradicional exibicionista no cinema narrativo, no qual "as mulheres são simultaneamente olhadas e exibidas, tendo sua aparência codificada no sentido de emitir um impacto erótico e visual de forma a que se possa dizer que conota a sua condição de "para-ser-olhada",75.

Todavia, apesar da representação da mulher como objeto erótico ${ }^{76}$, do predomínio do olhar masculino e da identificação entre este e o olhar do espectador, a condição de "para ser olhada" não se restringe à Nola, pois durante o filme existem diversas referências aos dotes físicos do protagonista. Chris é também apresentado como objeto do desejo da jovem Chloe Hewett e o ator escolhido por Allen também figura entre os mais belos eleitos pela mídia. Desse modo, tanto Chris quanto Nola executam a função do "para-ser-olhada". Vejamos como essa combinação entre semelhança e tensão é composta no filme.

\footnotetext{
72 Jonathan Rhys Meyer e Scarlett Johansson são fisicamente parecidos: brancos, loiros, lábios grossos, olhos claros, estatura mediana.

${ }^{73}$ Mulvey, Laura."Prazer visual e cinema narrativo (1973)". In: A experiência do cinema: antologia / Ismail Xavier (org.) Rio de Janeiro: Edições Graal: Embrafilmes, 1983, p.444.

${ }^{74}$ Ibid., p.444.

${ }^{75}$ Ibid., p.444.

${ }^{76}$ Conforme explica Mulvey: "Tradicionalmente, a mulher mostrada funciona em dois níveis: como objeto erótico para os personagens na tela e para o espectador no auditório, havendo uma interação entre essas duas séries de olhares.” Ver: Mulvey, op.cit., p.444-445.
} 
Em paralelo à cena de abertura, a câmera posiciona-se no meio da rede. Diferentemente da aristocrática quadra aberta de tênis que caracterizara o protagonista, observa-se uma mesa de pingue-pongue situada no interior da casa de campo. Pode-se ouvir o estridente barulho das bolinhas. Assim como na cena de abertura do filme, o espectador acompanha o jogo sem ver os jogadores. A bolinha, de movimento mais curto do que no tênis, bate na rede e cai para o lado esquerdo, onde o escopo de visão do espectador é maior. Nesse momento, a câmera subjetiva toma a posição do vencedor, que ainda não pode ser visto pelos espectadores. Ao fundo, Chris assiste à partida, em primeiro plano, enquanto o perdedor abandona a raquete de tênis de mesa e sai da sala de jogos. Sem que se possa vê-la, ouve-se a voz de uma mulher dizendo:

“Então, quem é a minha próxima vítima?"

O olhar da câmera subjetiva, portanto, permanece sob o controle da personagem que emite a voz feminina e observa o protagonista. Neste ponto, a provocação emitida pela voz feminina ao protagonista é evidente. Sem o uniforme de tenista, Chris que está vestido de terno, camisa e calça social (semelhante aos outros convidados da família Hewett), encara a jogadora. A câmera subjetiva muda de posição e toma o ponto de vista de Chris e observa-se a femme fatale: loira de cabelo preso, vestido branco, iluminada pela luz do sol ao fundo. Assim como Chris, Nola aparece como uma jogadora, porém, ela é desde o início apresentada como objeto erótico do olhar masculino. Na casa de campo, Nola costuma usar as roupas que foram utilizadas nos comerciais sensuais em que atuou, destacando-se como um objeto a ser mostrado por Tom entre os convidados. Essa característica também a aproxima do ex-tenista profissional que busca impressionar os Hewett e seus convidados por meio de suas habilidades como tenista inserido no circuito internacional.

No momento da entrada de Nola, por intermédio do uso da câmera subjetiva, observa-se que a visão da femme fatale é a de Chris: o espectador observa-a precisamente do ponto de vista do protagonista. Respondendo à provocação feminina, o ex-jogador profissional afirma que não joga "tênis de mesa há muito tempo". A provocação feita pelo protagonista é percebida neste momento apenas pelo espectador que sabe tratar-se de um ex-tenista profissional e indica certo rebaixamento do jogo de pingue-pongue em comparação ao tênis. $\mathrm{O}$ ex-jogador profissional faz uso da mesma justificativa anteriormente apresentada por seus 
alunos para explicar o mau desempenho: Chloe e Tom afirmam ter parado de jogar tênis há anos. A cena do jogo de pingue-pongue mimetiza a disputa entre Nola e Chris, intensificada por meio da técnica do campo/contra-campo:

[Nola Rice]: "Quer jogar a mil libras por partida?"

[Chris Wilton]: "No que me meti?"

[Nola Rice]: "No que eu me meti?"

Chris arremessa violentamente a bolinha de pingue-pongue, Nola afasta-se e o protagonista aproxima-se dela. O espectador observa, portanto, o ímpeto violento do ex-tenista quando se trata de uma jogadora de pingue-pongue - esporte que não é considerado tão nobre quanto o tênis. Desse modo, durante a apresentação de Nola, há certo desmascaramento do protagonista.

Todavia, por ser mulher em um ambiente patriarcal, Nola aparece em desvantagem quando comparada ao protagonista. Se contra o jogador inglês, amigo da família Hewett, Nola ganhara a primeira partida de pingue-pongue com facilidade, o segundo jogo, no qual ela tem Chris como adversário - o ex-tenista profissional que fora classificado por Sr. Townsend como um "ótimo analista das falhas dos jogadores" -, é violentamente decidido pelo protagonista. Conforme já fora demonstrado, a paciência e o pudor do professor de tênis que se manifesta para com os ingleses ricos, desaparecem no encontro com a jogadora de pinguepongue.

A audácia de Chris em aproximar-se da jogadora contrasta com a distância anteriormente apresentada entre o professor de tênis do Queen's Tennis Club e seus alunos ricos. A cena revela também que as chances de Nola no jogo são menores do que as do protagonista. Nola é mais peça do jogo de Chris do que jogadora, o que fica evidente no modo pelo qual o professor de tênis aproxima-se dela, dominando-a:

[Chris Wilton]: "É assim, posso?"

[Nola Rice]: "Por favor."

[Chris Wilton]: "Você tem que se inclinar e bater na bola."

[Nola Rice]: "Eu estava indo bem até você aparecer."

[Chris Wilton]: "A história da minha vida."

A cena antecipa o enredo, apresentando Nola como alguém que vencia o jogo até Chris aparecer. O protagonista retoma a sua atuação como tenista ao dizer que essa seria "a história 
de sua vida". Portanto, "curvar-se, bater na bola e ganhar o jogo" parece caracterizar o modo de vida do protagonista. Admirador do domínio patriarcal, Chris interrompe o jogo de Nola. A habilidade no esporte das elites, a vestimenta apropriada para as festividades na casa de campo, o gosto por ópera e por autores clássicos e o sotaque semelhante ao de seus alunos dão mais chances de entrada na família Hewett ao professor de tênis em comparação à Nola.

Em lugar de obedecer "a tomada alternada, conforme a lógica do texto, de um ou outro interlocutor" ${ }^{, 77}$, Allen apresenta a imagem de Nola sob o ponto de vista do protagonista. O encontro entre Nola e Chris evidencia, aos olhos do espectador, que os dois estão em busca do mesmo objetivo: entrar para o seleto mundo dos Hewett, ou seja, ascender socialmente por meio do casamento ${ }^{78}$. O ex-jogador profissional identifica prontamente a condição de Nola na família:

[Chris Wilton]: "Então, me diga, o que uma jovem e bonita jogadora norte-americana de pingue-pongue está fazendo no meio da classe alta britânica?"

[Nola Rice]: "Ninguém nunca lhe disse que você joga agressivamente?"

[Chris Wilton]: "Ninguém nunca lhe disse que você tem lábios muito sensuais?

[Nola Rice]: "Extremamente agressivo."

[Chris Wilton]: "Eu sou naturalmente competitivo. Você não gosta?"

[Nola Rice]: "Terei que pensar nisso por um tempo."

Nola e Chris são interrompidos pela entrada de Tom que a apresenta como sua noiva. Tom caminha em direção à câmera. Novamente, Allen utiliza o recurso da câmera subjetiva, desta vez, para aproximar o olhar de Chris e Nola que observam a chegada do jovem Hewett.

[Tom Hewett]: "Aí está você. Eu queria te apresentar para o Chris Wilton. Chris Wilton, esta é Nola Rice, minha noiva".

[Nola Rice]: "Então, você é o professor de tênis".

[Tom Hewett]: "Oi, querida."

[Chris Wilton]: "Muito prazer."

[Nola Rice]: "Ele estava tentando me ganhar sobre a mesa." 79

\footnotetext{
${ }^{77}$ Bazin, op.cit., p.75.

${ }^{78}$ É importante notar ainda que o primeiro encontro entre Chris, Chloe, Nola e Tom aconteça no Englefield Estate, propriedade que desde a Idade Média foi transmitida aos descendentes de uma mesma família por meio do casamento.

${ }^{79}$ No original em inglês, a conotação sexual explicita-se. Nola relata ao noivo a atitude do tenista: "He was trying to have his way with me over the table".
} 
[Tom Hewett]: "É mesmo? É melhor você tomar cuidado com este daí, ele ganha a vida fazendo isso."

[Nola Rice]: "Estarei pronta para você na próxima.

Tom apresenta Chris relacionando a atividade profissional deste à prostituição: “É mesmo? É melhor você tomar cuidado com este daí, ele ganha a vida fazendo isso." 80 Tom utiliza o verbo hustle $e^{81}$ para caracterizar as atividades profissionais de Chris. Em inglês, o verbo pode significar: um movimento rápido, apressado como um empurrão, ou um atropelo; vender ou obter coisas de forma ilegal ou desonesta e praticar um esporte de maneira agressiva. Ou ainda, hustle pode designar o trabalho relacionado à prostituição: tanto aquele que se prostitui quanto o que controla a atividade. Nesse ponto, apesar do olhar de Chris e Tom identificar Nola como objeto do desejo masculino, a menção à prostituição revela que não apenas a jovem norte-americana aspirante à atriz usa os dotes físicos para ascender socialmente, como também o faz o protagonista.

Em seguida, Nola sai da sala de jogos, a câmera acompanha os seus passos, sob o olhar de Chris e Tom. Os dois continuam fitando a porta da sala de jogos mesmo após a saída da jovem. Assim, podemos afirmar que a composição da mise-en-scène na apresentação de Nola aproxima Chris e Tom, os quais em relação à Nola apresentam o mesmo olhar voyeurista. No entanto, a cena também revela que apesar da tentativa do protagonista de "misturar-se à classe alta britânica", o objeto do desejo é controlado por Tom, proprietário e noivo da jovem atriz. Nola beija o noivo e provoca o protagonista ("Estarei pronta para você na próxima"), deixando os dois homens a sós:

[Nola Rice]: "Vejo você lá fora."

[Tom Hewett]: "Claro. Ela é muito boa, não é?"

[Chris Wilton]: "Há quanto tempo vocês estão juntos?"

[Tom Hewett]: "Seis meses. Meu Deus, seis meses! Ela veio para cá estudar teatro, nos conhecemos numa festa, fiquei muito interessado e ela também. Uma coisa levou a outra. Demorou um bom tempo para a minha mãe se acostumar com a ideia de que era sério. Para te falar a verdade, a minha mãe sempre teve uns planos esquisitos para mim que não envolve me casar com uma atriz em dificuldade. Sobretudo uma americana. Mas sou louco por ela. De qualquer forma, eu acho que nós deveríamos sair para jantar semana que vem, que tal?"

[Chris Wilton]: "Eu adoraria."

\footnotetext{
80 “Oh, really? You'd better watch out for this one. He's made a living out of hustling." webster.com/dictionary/hustle>. Acesso em: 6 jun. 2009.
}

${ }^{81}$ Disponível em: <http://www.ldoceonline.com/dictionary/hustle_1> e <http://www.merriam- 
[Tom Hewett]: "Ótimo. E agora, irlandês, que tal uma dose de uísque antes do jantar?"

[Chris Wilton]: "Por que não?"

[Tom Hewett]: "Vamos. Depressa."

A conversa entre camaradas revela o controle das ações pelo anfitrião da casa. Tom aponta os passos para Chris: "E agora, irlandês, que tal um pouco de uísque antes do jantar?" 82 Novamente, o diálogo em inglês acentua a ironia. De modo sarcástico, Tom oferece ao irlandês uma dose da bebida escocesa. Diferentemente da postura violenta demonstrada com Nola, o protagonista não revida à provocação do jovem herdeiro, obedecendo aos desígnios de seu aluno rico.

Ao trabalhar com o filme narrativo ilusionista, Allen conserva a "imagem da mulher como (passiva) matéria bruta para o (ativo) olhar do homem" ${ }^{\text {} 83}$. No entanto, o diretor faz uso da câmera subjetiva situando a ideologia da ordem patriarcal sob o ponto de vista de Chris e Tom (o herdeiro inglês que subordina os dois jogadores estrangeiros).

\title{
1.3 Uma tragédia americana
}

\begin{abstract}
"Seria difícil resumir aqui toda a situação do romance: não se pode fazer em cinco linhas o que Dreiser precisou de dois grossos volumes para fazer. Tocaremos apenas no ponto central do lado externo da história da tragédia o próprio assassinato, apesar da tragédia, é claro, não estar nisto, mas sim no trágico curso seguido por Clyde, a quem a estrutura social leva ao assassinato. E nosso roteiro dá atenção fundamental a isso.”
\end{abstract}

Sergei Eisenstein, em Sirva-se! sobre a adaptação para o cinema do romance Uma tragédia americana. .

$\mathrm{Na}$ cena da apresentação de Nola encontram-se ainda outras referências importantes para a configuração do foco narrativo e a questão do protagonista. Allen faz referência ao filme Um lugar ao sol (1951), de George Stevens. O paralelo entre o filme de Stevens e o de Allen foi apontado por muitos críticos ${ }^{84}$, que limitaram-se a indicar a semelhança. Neste ponto

\footnotetext{
82 "Now, Irish, how about a little drop of Scottish before supper?"

${ }^{83}$ Mulvey, op.cit., p.451-452.

${ }^{84}$ Destaca-se a comparação feita por Scott: “A primeira pista de que ele [Chris Wilton] pode ser outra coisa do que um meigo, bem-comportado puxa-saco acontece quando Chris encontra a noiva de Tom, a atriz norteamericana Nola Rice (Scarlett Johansson), em uma cena que levanta a temperatura do filme de educado banho-
} 
do trabalho, analisaremos o paralelo entre Um lugar ao sol e Match Point na cena da sala de jogos. E em seguida, passaremos à comparação com o romance Uma tragédia americana, de Theodore Dreiser, que originou o filme de Stevens, entre outros, conforme exporemos a seguir.

A primeira diferença que se pode observar entre Chris Wilton e George Eastman [Montgomery Clift], o protagonista de Um lugar ao sol, é que George é sobrinho de um importante industrial norte-americano. O laço de parentesco possibilita a contratação do protagonista nas empresas da família. No momento em que George chega à cidade para trabalhar na empresa do tio, a família Eastman prefere ignorar a presença do sobrinho pobre, excluindo-o do convívio social. Vemos aqui outra diferença entre George e Chris: o protagonista de Um lugar ao sol estudou pouco e preserva os hábitos que revelam a sua origem social, enquanto que, por sua vez, o protagonista de Match Point procura assemelharse aos Hewett por meio do esporte, do vestuário, dos livros, da música, do sotaque, etc.

Quando é convidado para uma festa na casa do tio, George não é apresentado pela família aos convidados, mas permanece como um estranho entre os ricos. O protagonista refugia-se na sala de jogos, local onde encontra Angela Vickers [Elizabeth Taylor], a menina rica pela qual se apaixona. Em Um lugar ao sol, a cena da sala de jogos aproxima o sobrinho pobre dos Eastman da jovem rica. Diferentemente, em Match Point, a sala de jogos marca o encontro entre os dois personagens de uma mesma classe social, o instrutor de tênis irlandês e a atriz norte-americana de comerciais sensuais.

Outra diferença fundamental para este trabalho entre o filme de Stevens e o de Allen está na maneira como os diretores compõem a cena. $\mathrm{O}$ foco narrativo em Match Point aproxima-se do protagonista por meio da utilização da voz over e da câmera subjetiva, enquanto Stevens faz uso do plano médio ${ }^{85}$. Em Um lugar ao sol, Angela entra na sala de

maria para a ebulição sexual. (A cena faz também uma homenagem discreta a Um lugar ao sol, adaptação do diretor George Stevens do romance de Theodore Dreiser Uma tragédia americana. O paralelo não pára aí. O rosto e olhar vigilante de Jonathan Rhys Meyers fazem lembrar Montgomery Clift. O que faz de Scarlett Johansson ou a próxima Elizabeth Taylor, ou a nova Shelley Winters. Hmm.)." Ver Scott, A. O. "London Calling, With Luck, Lust and Ambition". In The New York Times. December 28, 2005. Disponível em: <http://movies2.nytimes.com/2005/12/28/movies/28matc.html?ex=1165122000\&en=f64b1c3ba6aceaa1\&ei=507 $\underline{0}$ >. Acesso em: 6 jun.2009.

$\overline{85}$ Segundo Xavier, plano médio ou de conjunto é usado para "situações em que, principalmente em interiores (uma sala, por exemplo), a câmera mostra o conjunto de elementos envolvidos na ação (figuras humanas e cenário). A distinção entre plano de conjunto e plano geral é aqui evidentemente arbitrária e corresponde ao fato de que o último abrange um campo maior de visão”. Ver Xavier, Ismail. O discurso cinematográfico: a opacidade e a transparência. Rio de Janeiro: Paz e Terra, 1977, p.27. 
jogos e impressiona-se com a habilidade do jovem desconhecido. Os dois trocam olhares e se cumprimentam. A introdução da música extra-diegética acompanha o ar de romance suscitado pela imagem. Pode-se observar também a diferença social ao comparar o sotaque de Angela, proveniente de Lycurgus, Nova Iorque, com o de George, de Kansas City.

Por meio do plano médio, acompanhamos o movimento de Angela que perpassa a mesa de bilhar, observando George: "Vejo que você desperdiçou a sua juventude. Por que está sozinho? Você é reservado? Dramático? Melancólico?". Angela aproxima-se de George que permanece parado, esperando-a. Ele responde que está "apenas passando o tempo" e a convida para jogar. A jovem recusa, encosta na parede e diz que quer somente observá-lo. Em comparação a Match Point, a proximidade entre os personagens Chris e Nola no primeiro encontro contrasta com o distanciamento entre George e Angela, que recusa o convite para jogar com o estranho. A aproximação/distância entre os personagens deve-se à semelhança/diferença de classe.

George, antes de voltar a jogar, olha para Angela. A jovem rica o questiona: "Deixo você nervoso?". Angela identifica que George parece um Eastman: "Você é um deles?" O protagonista apresenta-se como um sobrinho. A concisão em identificar as classes sociais aproxima Um lugar ao sol a Match Point. No entanto, no filme de Stevens, ela é marcada pela diferença. Em comparação, no filme de Allen, a mulher apresentada na sala de jogos é assim como o protagonista, pobre em relação aos Hewett.

Assim como Tom em Match Point, no filme Um lugar ao sol, Angela observa e controla as ações do protagonista. Por sua origem social, a personagem Angela aproxima-se dos irmãos Hewett. A veneração de George pelos ricos evidencia-se na cena, quando ele diz à jovem rica que acompanha seus passos por meio das colunas sociais. Assim como Chloe, o interesse de Angela pelo jovem pobre advém dos atributos físicos do protagonista. Angela diz a George que ele "não parece comum." O atributo do protagonista em parecer-se com o primo, aproxima-o da jovem rica. Assim como os irmãos Hewett fazem com Chris, Angela conduzirá o protagonista ao convívio com os ricos.

Outro indício no filme de Stevens de que são os ricos que controlam os movimentos do protagonista pode ser observado por meio da entrada do anfitrião da festa, o tio de George, Samuel Griffiths. Sem apresentar o sobrinho à convidada, o industrial pergunta a respeito da mãe do protagonista. Samuel pede para que George escreva a ela contando sobre a promoção 
que ele ofereceu a George. Samuel relata à convidada Angela suas benfeitorias sociais: "Eu o fiz subir um degrau. Ele é um garoto esperto". Dessa maneira, o anfitrião pede para que George ligue para a mãe "imediatamente para contar as boas notícias".

O protagonista afasta-se de Angela para fazer a ligação. Enquanto isso, a jovem socialite brinca com a bolinha de bilhar. A cena é cortada para a Missão Independente de Bethel, no Kansas, espécie de local de culto religioso em que a família de George habita, onde o espectador pode observar o aviso: "Há quanto tempo você não escreve para a sua mãe?" Apesar da tentativa do protagonista de buscar privacidade e não expor-se frente aos ricos, Angela ouve a conversa de George com a mãe. Durante a ligação telefônica, a jovem rica abre um champanhe. $\mathrm{O}$ barulho interrompe a conversa por telefone. Angela brinca com a mãe de George: "Sou eu, mamãe". Assim como Tom, Angela zomba do protagonista: "Você prometeu ser um bom garoto? Não perder tempo com garotas? Ela o deixou sair esta noite? Deixou você dançar?" A jovem rica faz a passagem da sala de jogos para o convívio entre os convidados ricos da festa: "Vamos, levarei você para dançar no seu aniversário, menino triste".

Dessa forma, na cena da sala de jogos do filme de Stevens, filmada em plano médio, o protagonista apaixona-se pela jovem rica que o conduz à alta sociedade. Por sua vez, na sala de jogos do filme de Allen, por meio da utilização da câmera subjetiva, a visão de Nola como objeto erótico é compartilhada por Chris, Tom e o espectador. O protagonista alia-se ao jovem rico e a batalha não será contra as barreiras sociais que impedem a entrada do protagonista à alta sociedade (como no filme de Stevens). Haverá uma luta intra-classes, conforme indica a partida de pingue-pongue. Nola e Chris não se unem com o intuito de lutar contra o opressor, mas rivalizam entre si a aliança com a família rica.

Após apresentar as semelhanças e diferenças entre Um lugar ao sol e Match Point retomaremos o romance Uma tragédia americana (1925), de Theodore Dreiser. A obra de Dreiser é recorrente na história do cinema: o romance deu origem aos trabalhos inconclusos de alguns dos principais cineastas do mundo, tais como David Wark Griffiths, Ernst Lubitsch e Sergei Eisenstein e foi adaptado por F.W. Murnau, no filme Aurora ${ }^{86}$ (1927); Joseph von Sternberg, em Uma tragédia americana (1931) e, finalmente, conforme exposto acima, por George Stevens, em Um lugar ao sol (1951).

\footnotetext{
${ }^{86}$ No original Sunrise: a song of two humans.
} 
No intuito de expor a configuração do foco narrativo em Match Point, utilizaremos algumas das reflexões sobre o romance de Dreiser feitas por Eisenstein. A escolha pelo texto de Eisenstein deve-se ao fato de que o cineasta russo apresenta no artigo ${ }^{87}$ sobre Uma tragédia americana, escrito em 1932, a exposição sobre o "monólogo interior cinematográfico, cujo alcance é muito mais amplo do que o permitido pela literatura" ${ }^{\wedge 8}$. Dreiser e Eisenstein trabalharam juntos para que o filme dirigido pelo cineasta russo fosse realizado. Dreiser inclusive elogiou as alterações feitas por Eisenstein. No entanto, os estúdios Paramount, que detinham os direitos autorais para a adaptação cinematográfica do romance de Dreiser, não concordaram com o tratamento dado por Eisenstein e entregaram o direito de adaptação do romance a Josef von Sternberg que atendeu "aos desejos do estúdio - e filmou um simples caso policial” ${ }^{\prime 89}$. A adaptação de Sternberg foi feita, portanto, a contrapelo de Dreiser, que levou os estúdios Paramount aos tribunais para que o seu romance fosse adaptado por Eisenstein. Apesar do trabalho de Eisenstein sobre o romance de Dreiser ter sido censurado pelos estúdios, e por isso o filme não fora realizado, as reflexões do cineasta sobre a adaptação do livro e as possibilidades de utilização do monólogo interior no cinema são de extrema importância para esta análise do filme de Woody Allen.

No plano do enredo, as semelhanças entre o protagonista do romance de Dreiser Clyde Griffiths e Chris Wilton são significativas: os dois são filhos de pastores de origem pobre, desejam ascender socialmente, viajam para a cidade em busca de melhores oportunidades, envolvem-se com uma garota pobre que engravida e representa uma ameaça ao casamento com uma menina rica e por fim, decidem assassinar a namorada pobre, visando uma carreira promissora e o sucesso ao lado dos ricos. Todavia, Clyde Griffiths não é culpado.

Apesar da indiscutível evidência de que Clyde planejara o assassinato, no momento do crime ele vacila. No entanto, percebendo as intenções de Clyde, Roberta Alden (a garota pobre que está grávida de Clyde) desespera-se. Ela aproxima-se de Clyde, mas desequilibrase. Acaba batendo a cabeça na câmera fotográfica do protagonista, a canoa vira e os dois

\footnotetext{
${ }^{87}$ Existem duas traduções para o português do artigo de Eisenstein, ambas utilizam a versão americana do texto originalmente publicado em Proletarskoye Kino, $\mathrm{n}^{\circ} 17 / 18$, em 1932. Na tradução em inglês, o texto está publicado com o título "A course in treatment", no livro Film form (Meridian Books. New York, 1957). A versão utilizada neste trabalho parte do livro A forma do filme, trad. Teresa Otoni. A primeira tradução para o português foi feita por Vinicius Dantas e pode ser encontrada sob o título "Da literatura ao cinema: Uma tragédia americana", na antologia A experiência do cinema. Não existe tradução direta do original russo para o português.

${ }^{88}$ Eisenstein, Sergei (1898-1948). A forma do filme / Sergei Eisenstein; apresentação, notas e revisão técnica, José Carlos Avelar; trad.Teresa Otoni. Rio de Janeiro: Jorge Zahar Ed., 2002, p.104.

${ }^{89}$ Ibid., p. 106.
} 
caem no rio. Para mostrar a febril corrida de pensamentos do protagonista, Dreiser descreve "os murmúrios interiores de Clyde" $" 90$ :

Você pode salvá-la. Mas ao mesmo tempo não pode! Veja como ela se debate. Ela está atordoada. Ela é incapaz de salvar-se, está aterrorizada, se você se aproximar dela agora, isso pode provocar a sua morte também. Mas você deseja viver! E a vida dela vai fazer a sua não valer a pena a partir de agora. Espere um pouco - uma fração de minuto! Espere - espere - ignore a piedade deste apelo. E então - então - lá está! Olhe. Acabou. Ela está afundando agora. Você nunca mais vai vê-la viva - para sempre. ${ }^{91}$

Conforme argumenta Eisenstein, "as aventuras de Clyde em seus choques com a realidade norte-americana já haviam moldado sua psicologia, de modo que, após uma longa luta interior (não devido a princípios morais, mas à sua própria e neurastênica falta de caráter), ele se decide pela última opção" ${ }^{92}$. Para Eisenstein, o crime planejado pelo jovem deveria ser entendido, como "a soma total das relações sociais cuja influência ele sofreu em todos os estágios de desenvolvimento de sua biografia e caráter, no decorrer do filme."93

Das adaptações para o cinema supracitadas, a cena do afogamento da garota pobre é a que mais trouxe controvérsia. Nos filmes de F.W. Murnau, Josef von Sternberg e George Stevens, a cena foi trabalhada de maneira diversa da proposta por Eisenstein e aprovada por Dreiser, na qual, a sequência dos acontecimentos na vida de Clyde, a estrutura social, leva ao assassinato. $\mathrm{O}$ monólogo interior também não foi alcançado por nenhum desses autores que adaptaram Uma tragédia americana. Para Eisenstein, toda a perturbação e a luta interior do protagonista seriam expostas por meio do monólogo interior: "a câmera tinha de ir "dentro" de Clyde. Auditiva e visualmente, era preciso mostrar a febril corrida de pensamentos intercalados com a realidade externa - o barco, a moça sentada do lado oposto a ele, suas próprias ações."94

No filme de Murnau, Aurora (1927), observa-se o encantamento do pequeno fazendeiro pela garota da cidade. A arrivista planeja o crime e pede para que ele execute-o, afogando a esposa. Fascinado pela possibilidade de sucesso na cidade ao lado da arrivista, o pequeno

\footnotetext{
${ }^{90}$ Ibid., p.103.

${ }^{91}$ Dreiser, Theodore. An american tragedy (1925). New York: Signet Classic, 2000, p.514.

${ }^{92}$ Eisenstein, op.cit., p.99.

${ }^{93}$ Ibid., p.98.

${ }^{94}$ Ibid., p. 103.
} 
fazendeiro leva a esposa até o barco, mas não comete o crime. Acompanhamos os seus olhos agitados, as sobrancelhas arqueadas, as mãos trêmulas. A esposa descobre o intento do marido e afasta-se dele. O pequeno fazendeiro rema até a cidade. Em meio ao caos da metrópole, o casal se reaproxima. No retorno à fazenda, uma forte tempestade faz o barco virar. Todavia, a esposa é salva pelos gravetos que o marido lhe dera e por outros pequenos fazendeiros que a encontram. Assim, o jovem casal é restabelecido, eles voltam à casa junto ao filho e a forasteira é expulsa da comunidade.

Conforme se pode observar, o filme de Murnau faz diversas intervenções no enredo do romance de Dreiser, culminando no restabelecimento da família de pequenos proprietários. O filme de Sternberg transformou o romance em um "simples caso policial" ". Por sua vez, Stevens, em Um lugar ao sol (1951), segue o enredo de Dreiser. No intuito de casar-se com a jovem rica Angela, George leva a garota pobre Alice Tripp [Shelley Winters], que espera um filho dele, para o passeio de barco. Todavia, no momento decisivo, ele não consegue prosseguir. A música extra- diegética utilizada por Stevens intensifica o suspense da cena. Alice desequilibra-se no barco, cai e se afoga. George foge e vai ao encontro de Angela, mas é capturado pelos policiais, julgado e condenado à cadeira elétrica, como no romance de Dreiser.

A utilização da música extra-diegética no filme de Stevens é um exemplo da maneira tradicional do cinema clássico de inclusão da música na narrativa. Stevens realiza exatamente o que Brecht caracteriza como a utilização padrão do cinema narrativo. O exemplo abaixo, retirado do texto de Brecht, refere-se precisamente à adaptação para o cinema do romance de Dreiser:

Um jovem leva a namorada para um passeio de canoa no lago, o barco vira e ele deixa a garota se afogar. O compositor tem duas opções: ele pode antecipar os sentimentos do público por meio da música de acompanhamento, desenvolvendo a tensão, aumentando o mal do acontecimento, etc. Ou então, ele pode expressar por meio da música a serenidade do lago, a indiferença da natureza, o caráter cotidiano do evento, na medida em que é um simples passeio de barco. Se ele escolher esta última opção, permitirá que o assassino pareça ainda mais terrível e antinatural, ele dá a música uma função mais independente. ${ }^{96}$

\footnotetext{
${ }^{95}$ Ibid., p.106.

${ }^{96}$ Brecht, Bertolt (1898-1956). Brecht on film and radio - transl. and edited by Marc Silberman. Methuen, 2000, p.14.
} 
A partir das reflexões de Brecht, podemos observar que o filme de Stevens faz uso da tradicional música de acompanhamento: a música desenvolve a tensão e acompanha o enredo. Por intermédio da leitura do artigo de Eisenstein, vemos que o cineasta russo queria, através do monólogo interior, estabelecer o contraste entre os pensamentos, as palavras interiores de Clyde em relação às circunstâncias externas: "a sintaxe do discurso interior, distintamente da do discurso exterior"97. Em Match Point, Allen não faz uso do monólogo interior, conforme proposto por Eisenstein. No entanto, por meio da voz over, da câmera subjetiva, da montagem e da utilização da ópera no filme, entre outros recursos que exporemos a seguir, o diretor nova-iorquino relativiza o discurso do protagonista.

\subsection{Visões de mundo (em conflito)}

“O favor é, portanto, o mecanismo através do qual se reproduz uma das grandes classes da sociedade, envolvendo também outra, a dos que têm. Note-se ainda que entre estas duas classes é que irá acontecer a vida ideológica, regida, em conseqüência, por este mesmo mecanismo.”

Roberto Schwarz, As ideias fora do lugar.

Na cena seguinte à da sala de jogos na casa de campo, vemos Chris e Chloe saírem da Saatchi Gallery ${ }^{98}$. A música extra-diegética acompanha a cena. Allen utiliza a ária "Mia

\footnotetext{
${ }^{97}$ Eisenstein, op.cit., p.105.

${ }^{98}$ Em A privatização da cultura, Chin-tao Wu explica, entre outros aspectos que serão retomados ao longo deste trabalho, a transformação do capital cultural em capital econômico pelas elites norte-americanas e inglesas. Os irmãos Saatchi, donos da empresa de publicidade Saatchi \& Saatchi responsável por vender a imagem de Margaret Tatcher, ganham importante destaque na análise de Wu: "Os irmãos Saatchi oferecem uma excelente ilustração do intercâmbio das várias formas de capital e dos problemas resultantes da concentração de poder facilitada, quando não incentivada, pelo governo conservador. [...] Usando suas diferentes bases de poder, pessoas como os irmãos Saatchi estão em posição privilegiada para transformar parte de seu capital econômico em capital cultural, o que eles fazem, por exemplo, quando suas fortunas e influência pessoais lhes permitem acesso aos conselhos curadores de galerias de arte e museus. Eles então transformam esse capital cultural novamente em capital econômico, pelo uso da arte como mercadoria. O que torna vicioso esse círculo é que ele funciona alheio à atenção pública, mesmo quando opera por meio de instituições públicas. Fortunas pessoais são criadas, sustentadas e ampliadas por um pequeno número de indivíduos auto-eleitos, que alegam agir por motivos desprendidos, de interesse público, e são agraciados com o dom invejável de serem capazes de fazer vista grossa para qualquer sinal de conflito de interesses que surja no horizonte". Ver: Wu, Chin-tao. Privatização da cultura: a intervenção corporativa nas artes desde os anos 1980 / Chin-Tao Wu; tradução Paulo Cezar Castanheira. São Paulo: Boitempo, 2006.
} 
Piccirella"99 , cantada por Caruso. Assim como um casal de turistas, a inglesa Chloe apresenta ao irlandês Chris os cartões-postais da cidade: o rio Tâmisa, o palácio de Buckingham, a troca da guarda. Eles terminam o trajeto no cinema, onde assistem ao clássico do cinema noir Rififi $^{100}$ (1955), de Jules Dassin. Na cena, ouvimos apenas a voz dos personagens do filme de Dassin. Enquanto assistem ao filme, o professor de tênis conta a jovem rica que precisa de "mais alguns alunos". Chloe oferece dinheiro a Chris, o irlandês recusa educadamente: "É muita gentileza sua perguntar, mas eu não preciso". Os dois se beijam e Chloe, interessada na aptidão sexual do tenista, pergunta: "Vamos para a minha casa ou para a sua?" A cena seguinte mostra os dois no sofá do apartamento de Chris, ao som de "Mia Piccirella". Ao colocar em paralelo o filme de Dassin sobre ladrões que realizam um crime perfeito - mas acabam rivalizando entre si - , as dificuldades financeiras do protagonista e o início do romance entre o jogador e a "piccirella", o filme antevê o "golpe" que Chris planeja.

A maneira refinada e precisa com que Allen estrutura a narrativa em Match Point pode ser observada também por meio da montagem dos planos. Para mostrar o início do romance entre o professor de tênis e a jovem herdeira, Allen apresenta o encontro na ópera, o jogo de tênis na casa de campo, o passeio por pontos turísticos da cidade, a ida ao museu, ao cinema, ao apartamento de Chris e, em seguida, o diretor corta e focaliza a fachada de uma residência das classes abastadas britânicas. A fachada da casa dos Hewett estabelece o contraste, aos olhos do espectador, entre este local e o apartamento pequeno do protagonista.

Após apresentar a fachada, Allen mostra o interior do local, onde vemos a matriarca Eleanor descendo a escadaria. As escadarias das residências apresentadas em Match Point serão reiteradamente expostas no filme, contribuindo à ideia do arrivismo. Nesse ponto, a residência dos Hewett pode ser comparada à de Samuel Griffiths em Uma tragédia americana. A casa do tio de Clyde conta com uma escada estonteante que chama a atenção do protagonista. Ele admira sua tia descendo a escadaria e aproximando-se dele, a senhora

\footnotetext{
99 Escrita pelo compositor brasileiro Carlos Gomes, "a canzonetta "Mia Piccirella" se transformou numa das melodias mais populares da época". Ela abre o ato I, cena 1, da ópera Salvator Rosa: "No atelier do pintor Salvator Rosa em Nápoles, em 1647. Salvator, sentado e ocupado em pintar um retrato, pergunta a Gennariello o que acha da pintura, ouvindo como resposta que o céu está muito carregado, o mar tétrico e as damas com mau semblante. Concorda o pintor, para quem só uma mulher interessa, o que, diz Gennariello, também acontece com ele, tanto que escreveu uma serenata à sua bela. Acompanhando-se do bandolim, canta "Mia Piccirella"'. Ver: Kobbé, op.cit., p.540-541.

${ }^{100}$ No original Du Rififi chez les Hommes.
} 
Griffiths apresenta-se ao sobrinho com "certa serenidade que os anos de contato com a alta sociedade local lhe deram" ${ }^{101}$.

Assim como a tia de Clyde, a matriarca Eleanor Hewett prefere manter certa distância em relação ao jovem professor de tênis irlandês. Ao entrar na sala de estar, repleta de objetos de arte, a mãe de Chloe afirma querer "entender o que Chris procura"; a filha responde que "ele com certeza não quer ser professor de tênis pelo resto da vida". Por sua vez, o patriarca, Alec, considera o jovem irlandês “(...) muito simpático. Ele subiu na vida da única forma que podia e não é trivial. Tive uma conversa muito interessante com ele outro dia sobre Dostoievski." Neste ponto, pode-se observar que a predileção do protagonista aos clássicos, e a coletânea do Cambridge Companion, é reconhecida pela família e capitalizada ${ }^{102}$ pelo patriarca. Ao perceber o apreço de Alec por Chris, Chloe pede um favor ${ }^{103}$ ao pai: "Não podemos fazer algo por ele? Um emprego em uma de suas empresas?”. A matriarca pede para que a filha "tome cuidado" e "vá devagar", pois Tom já está envolvido com uma garota que Eleanor tem "restrições". Na opinião da mãe de Chloe e Tom, Nola é mimada e temperamental: "Ela se ilude e é instável. Não serve para o Tom”. Na cena, o espectador tem acesso à opinião dos Hewett sobre os dois estrangeiros, a norte-americana Nola e o irlandês Chris. O indício, suscitado pelas cenas anteriores de que Nola seria uma competidora inferior a Chris, é confirmado: a matriarca está insatisfeita com o noivado do filho. E o interesse do protagonista pela alta cultura favorece sua entrada para a família. Portanto, o protagonista é beneficiado pela predileção da família Hewett a ele em detrimento de Nola.

Um novo corte rápido revela que Chris será acolhido pelos Hewett. Na cena seguinte, Chloe entra no restaurante Brasserie Max ${ }^{104}$, localizado no hotel Convent Garden, onde o

\footnotetext{
${ }^{101}$ Dreiser, op.cit., p.219.

${ }^{102}$ Segundo López-Ruiz, a "capitalização" de aptidões, habilidades e destrezas pessoais é um sintoma do espírito do capitalismo contemporâneo: "As pessoas capitalizam-se consumindo e podem fazê-lo de inúmeras formas: capitalizam em qualidade de vida, por isso é legítimo investir em viagens; capitalizam na própria carreira, por isso é legítimo investir tempo e dinheiro em treinamentos; capitalizam em relacionamentos, por isso é legítimo investir em sofisticados e caros objetos de design na decoração de suas casas; capitalizam em cultura, por isso é legítimo investir em cursos acelerados que dêem códigos sistematizados para que a fast culture possa ser digerida-comentada-capitalizada." Ver: López-Ruiz, op.cit., p.225-226.

${ }^{103}$ Neste trabalho, a prática do favor é entendida conforme exposta por Roberto Schwarz: "No processo de sua afirmação histórica, a civilização burguesa postulara a autonomia da pessoa, a universalidade da lei, a cultura desinteressada, a remuneração objetiva, a ética do trabalho etc. - contra as prerrogativas do Ancien Régime. O favor, ponto por ponto, pratica a dependência dá da pessoa, a exceção à regra, a cultura interessada, remuneração, e serviços pessoais”. Ver: Schwarz, Roberto. “As ideias fora do lugar”. In: Ao vencedor as batatas. São Paulo: Duas Cidades, 1992, p.16.

${ }^{104}$ Allen usou o elegante restaurante do hotel, o Max Brasserie, para reunir o quarteto. "O restaurante é bastante conhecido pelos frequentadores do Royal Opera House (próximo ao local), o estabelecimento orgulha-se de sua
} 
protagonista a aguarda. Logo na primeira fala, Chris explicita o assunto: "Um dos sócios do seu pai falou comigo hoje sobre a possibilidade de um emprego. Você disse alguma coisa?" Chloe tenta convencer o namorado a aceitar a oferta: "Papai disse que é uma chance de aprender o negócio. E, se tudo der certo, ele cuidará para que você seja promovido rapidamente". Apesar da proposta tentadora, Chris reluta: "Eu nunca gostei muito da ideia de trabalhar no escritório". Chloe argumenta que o trabalho será como uma escada, ela enuncia a questão do arrivismo: "Não é bem um trabalho no escritório. Pense nele como uma escada para um cargo melhor, maiores responsabilidades, um salário melhor, sei lá. Você sempre disse que admirava as conquistas do meu pai." O protagonista aceita a oferta: "Claro. É estranho, mas vindo de onde eu vim, sempre admirei homens como o seu pai: rico sem ser arrogante, desfrutando a sua fortuna, aproveitando a vida, patrocinando as artes." Observa-se aqui movimento semelhante ao descrito por Roberto Schwarz: “Ao legitimar o arbítrio por meio de alguma razão 'racional', o favorecido conscientemente engrandece a si e ao seu benfeitor, que por sua vez não vê, nessa era de hegemonia das razões, motivo para desmentilo. Nestas condições, quem acreditava na justificação? A que aparência correspondia? Mas justamente, não era este o problema, pois todos reconheciam - e isto sim era importante - a intenção louvável, seja do agradecimento, seja do favor." ${ }^{105}$ A jovem herdeira, novamente, expõe o favor, a oportunidade, aberta por seu pai, ao protagonista: "Ele realmente quer abrir algumas portas para você, só isso. Ele o respeita pelo modo como você superou as dificuldades.". Chris promete a Chloe que dará a "sua contribuição".

O casal é interrompido pela chegada de Nola e Tom, os dois casais dirigem-se à mesa e conversam. Sentados à mesa do restaurante, Tom conta sobre uma exposição de carros em que ele e Nola estiveram. Ele pergunta ao professor de tênis se Chris gosta "de seus carros". O protagonista, que não é proprietário de nenhum veículo, compartilha com Nola a preferência por carros antigos. A aproximação entre os dois estrangeiros dá--se desde o início da cena no restaurante. Nola explica a Chris que o noivo gosta de carros novos, "cheios de acessórios". E acrescenta que gostaria de ter um Aston Martin. O protagonista explica aos presentes, olhando para Nola, que ele já dirigiu um Aston Martin: "Eu trabalhava para um senhor e tinha que lavar os carros dele. Ele era muito meticuloso sobre como eu deveria cuidar dos carros. Então, eu tinha que lavá-los diariamente com uma escova de dente". Chloe ri do trabalho feito pelo

excelente cozinha britânica moderna". Disponível em: <http://www.visitbritain.us/press/news/newsreleases/2005/nr051209match-point.aspx>.Acesso em: 13 jan. 2010.

${ }^{105}$ Schwarz, op.cit., p.17. 
namorado. Nola justifica sua escolha pelo veículo, o que revela também seu fascínio pelo mundo dos ricos: "Eu quero um Aston Martin, ou um daqueles Mercedes conversíveis clássicos”. Enquanto observa o cardápio, Tom expõe à noiva a condição para que ela obtenha os veículos que deseja: “Quando nos casarmos, colecionaremos carros clássicos. Conquanto que eu possa ter um DB9 com todos os acessórios, ok? Por falar nisso, Hedley é perfeita para guardar todos esses carros. E por falar em Hedley..." Chloe interrompe o irmão para que façam o pedido, “o garçom está esperando".

Tom pede "batata com trufas" e Nola copia o pedido do noivo, o que indica que a atriz já abdicou de seu direito de escolha. Por sua vez, o casal Chloe e Chris "discute" o pedido. Enquanto Chloe quer "caviar blinis", Chris prefere "frango assado". A preferência do protagonista pela refeição comum pode tanto tratar-se de uma escolha autêntica de Chris quanto revelar que o protagonista decide-se pelo prato por conta do preço. A conversa trivial revela o que está em jogo: depois da resistência de Chris, que prefere continuar com o pedido que havia feito anteriormente, Chloe pergunta se o professor de tênis gosta de caviar, ao que Chris responde gostar "mais ou menos". Chloe justifica ao garçom a escolha do namorado, considerada por ela vulgar: "Ele foi educado para ser modesto, desculpe-me." Tom faz o pedido por Chris: "Ele comerá blinis". Após ouvir o pedido de Chris feito pelo jovem rico, o garçom retira-se da mesa.

Assim, na cena evidencia-se que, na presença de Chloe e Tom, Chris perde o poder de escolha. Após a saída do garçom, a herdeira Hewett volta a questionar a atitude do namorado: “Meu Deus, o seu pai era um petroleiro especialista em etiqueta?". Chris responde à provocação: "Sim. Ele era um pouco austero." Chloe volta a complementar as palavras de Chris: "O pai de Chris era um fanático religioso." O protagonista confirma: "Após perder as duas pernas, [meu pai] encontrou Jesus." Os irmãos Hewett riem da informação sobre o pai do professor de tênis e Tom satiriza: "Meu Deus. Sinto muito. Mas, não me parece uma troca justa." Neste ponto, a câmera mais uma vez seleciona o foco da atenção do espectador. Se antes Chloe e Chris estavam em primeiro plano, agora Nola e o protagonista passam ao centro da narrativa. Apesar de ouvirmos a voz dos irmãos Hewett, o olhar da câmera focaliza a troca de olhares entre os forasteiros.

[Chris Wilton]: "Você já participou de muitos filmes?"

[Nola Rice]: "Era um comercial, não um filme." 
[Tom Hewett]: "Mas os seus olhos iam diretamente para ela, se é que me entende." planejei."

[Nola Rice]: "Não acho que a minha carreira evoluiu como eu

[Tom Hewett]: "Ah, você só precisa de um tempo."

[Chris Wilton]: "Acredito que a sorte é importante em tudo."

A troca de casais na cena é nítida: o foco da atenção do espectador, o qual no começo da cena estava centrado na discussão entre Chloe e Chris, agora atesta a aproximação entre os arrivistas. Na cena expõe-se também o embate entre visões de mundo díspares (a dos Hewett e a dos estrangeiros):

[Chloe Hewett]: "Eu não acredito na sorte, só no esforço."

[Chris Wilton]: "Claro, esforço é essencial, mas eu acho que todo mundo teme admitir a importância da sorte. Parece que os cientistas estão confirmando que toda a existência está aqui por acaso, sem propósito, sem projeto."

[Chloe Hewett]: "Bem, eu não ligo. Eu amo cada minuto dela."

[Chris Wilton]: "E eu a invejo por isso."

[Tom Hewett]: "O que o vigário costumava dizer? 'Desespero é o caminho da menor resistência'. Algo estranho, não?"

[Chris Wilton]: "Acredito que a fé é o caminho da menor resistência."

[Tom Hewett]: "Nossa! Meu Deus!"

[Chloe Hewett]: "Podemos mudar de assunto, por favor? Nola falava de atuação, que é muito mais interessante."

[Nola Rice]: "Não, eu só disse que estou pensando em deixar a carreira de atriz em segundo plano. Não aguento que as pessoas na minha cidade pensem que eu fracassei. Não que eu vá voltar para o Colorado. Nunca."

Enquanto os Hewett acreditam na ideologia burguesa do esforço, Chris defende a sorte e Nola relata sua trajetória de vida. A maneira como Allen compõe a cena do restaurante desarmoniza as visões de mundo apresentadas. Antes da entrada de Tom e Nola, Chloe acerta o futuro do protagonista. Dessa forma, o espectador sabe que um bom emprego é ofertado ao protagonista por relações de favor, e não pelo esforço. Conforme o próprio protagonista revela, ele não possui experiência como executivo, nem se interessa em trabalhar no escritório. Todavia, ele aceita o emprego, pois sabe que será importante para entrar para a família. Outra informação crucial, apresentada na mesma cena, revela a instabilidade de Nola na carreira de atriz. A noiva de Tom considera abandonar a profissão, o que Chloe contesta, deslumbrada com a possibilidade de atuação de sua futura cunhada na indústria do entretenimento: "Nola falava de atuação, o que é muito mais interessante". Na conversa com a 
mãe, Chloe defendera a noiva do irmão justamente por seu trabalho: "Ela é atriz, eles são sensíveis". A cena do restaurante mostra também o exíguo poder de decisão dos jovens forasteiros em relação aos Hewett. A decisão de Nola pelo veículo clássico está condicionada ao casamento com o jovem herdeiro. Nola pede o mesmo prato que o noivo assim como Chris não pode escolher o seu pedido. A jovem atriz norte-americana é interrompida pelo garçom que solicita se os clientes já escolheram o vinho. Novamente, a decisão cabe a Tom que pede "duas garrafas de Puligny-Montrachet."

Afastando-se dos irmãos Hewett, a câmera focaliza a troca de olhares e a crescente aproximação entre Nola e Chris. A identificação entre os dois não se dá apenas na chave da sedução: há uma correspondência de classe. A cena seguinte confirma a trajetória ascendente do professor de tênis que, diferentemente de Nola, muda de profissão com o auxílio dos Hewett, transformando-se em executivo. O novo trabalho do protagonista é essencial para que o espectador prossiga na identificação de quem é este personagem e como ele se apresenta na configuração social.

\title{
1.5 Capital e empreendedorismo
}

\footnotetext{
“A ética do trabalho empresarial não é, enfim, a ética dos executivos das corporações transnacionais: é a ética do trabalho proposta atualmente para a sociedade em conjunto."
}

Osvaldo López-Ruiz, Os executivos das transnacionais e o espírito do capitalismo.

\begin{abstract}
"Na verdade, a associação histórica da arquitetura sempre foi com os donos do poder e do dinheiro, sobretudo com a propriedade privada, da terra e do capital." Pedro Arantes, O grau zero da arquitetura na era financeira.
\end{abstract}

Entre o sistema de personagens Chris Wilton, Nola Rice, Chloe Hewett e Tom Hewett, a sociabilidade é mediada pela estrutura de classe. Nenhuma das ligações entre os pares se dá de forma autônoma. Chris e Nola ligam-se, respectivamente, a Chloe e Tom visando à ascensão social por meio do casamento com a elite britânica. Os dois estrangeiros 
aproximam-se por conta da correspondência de classe. Por sua vez, Tom e Chloe são irmãos. A associação e o conflito entre os personagens ganham contornos mais definidos, por exemplo, na cena do restaurante mostrada anteriormente. Apesar da aproximação entre o professor de tênis e a atriz norte-americana, os dois estrangeiros disputam entre si por um lugar entre os ricos.

$\mathrm{Na}$ cena do restaurante sabe-se que Chris recebeu uma promissora oferta de emprego oferecida pela família Hewett. Os bons modos do protagonista, ou a "etiqueta" (conforme caracteriza Chloe), desperta a confiança da família endinheirada que lhe oferece uma vaga na empresa. A entrada do professor de tênis para o mundo dos negócios é feita logo em seguida à cena do restaurante, que explicita a forma de sociabilidade baseada nas relações de favor. No núcleo do capital financeiro, portanto, o que funciona não é nem a sorte nem o mérito, mas o favor, a influência pessoal.

A maneira como Allen estrutura o foco narrativo na cena é precisa. Em primeiro lugar, vê-se o exterior do prédio. O diretor apresenta o imponente edifício Swiss $R^{106}$, também conhecido como Gherkin ${ }^{107}$. A cena é filmada em contre-plongée (Figura 1$)^{108}$, o que ressalta a magnificência da construção. O prédio, projetado em formato ogival, destaca-se imediatamente na paisagem londrina, característica que é incorporada pelo plano, pois o Swiss $R e$ aparece ao lado de outros edifícios de escritórios comuns (em formato de blocos, não como ogivas). A construção, portanto, realça o poderio da família Hewett, elemento que não passa despercebido pelo protagonista.

Se nesse ponto apresenta-se a aliança entre o irlandês e uma família da elite britânica, a história da construção do Swiss Re oferece um importante contraponto à trajetória do arrivista. O edifício escolhido por Allen traz consigo uma reminiscência do confronto entre a

\footnotetext{
106 “Desenvolvido pela Swiss Re e projetado pelos arquitetos da empresa Foster and Partners, o prédio possui 40 salas de escritório situadas no coração da City [centro financeiro] de Londres. O edifício, inaugurado oficialmente em março de 2004, possui alguns dos mais adaptáveis e bem-avaliados escritórios de Londres." Disponível em: <http://www.buildingtheSwiss Re.com/pdf/factsandfigures.pdf >. Acesso em: 13 jan.2010.

107 "O 30 Street Mary Axe, localizado no centro financeiro de Londres, é carinhosamente conhecido pelos londrinos como the Gherkin [o pepino], ou the Erotic Gherkin [o pepino erótico]. Situado no local do antigo The Baltic Exchange, construção que foi gravemente danificada por um ataque a bomba comandado pelo IRA [Exército Republicano Irlandês], em 1992. Controversa, a decisão foi de demolir o Exchange, listado como Grade II [classificação para os prédios britânicos de comprovado valor histórico, protegidos por lei]. A nova torre parece um pouco com uma bala de revólver: circular, mais estreita na base. O alargamento dos pisos de cima, antes de afinar para o ápice, oferece uma visão única do horizonte de Londres. Mais do que isso, o ilustre novo edifício foi concebido para usar 50\% a menos de energia do que um prédio de escritórios comum." Disponível em: <http://london.allinfo-about.com/features/Swiss Re.html>. Acesso em: 13 jan. 2010.

108 Algumas cenas e ilustrações serão apresentadas em Anexo(s) ao final do trabalho.
} 
Irlanda e o império britânico. Em 1992, um atentado a bomba promovido pelo IRA (Exército Republicano Irlandês) atingiu o 30 St. Mary Axe. O terreno localiza-se no centro financeiro de Londres e antes da construção do Swiss Re era ocupado pelo antigo Baltic Exchange ${ }^{109}$. A própria construção do edifício funciona como uma espécie de apagamento da história da cidade $^{110}$. O edifício que outrora ressaltava a pujança do comércio marítimo inglês foi demolido para a construção do Swiss Re e dividido em pedaços ${ }^{111}$.

Apesar de não existir nenhuma correlação imediata no filme entre o Exército Republicano Irlandês e a história de Chris Wilton, é preciso retomar que se trata da entrada de um irlandês, apadrinhado pela elite britânica, no centro do capitalismo britânico. Não se trata de um posto em um prédio de negócios comum, mas da entrada do protagonista no edifício símbolo da arquitetura rentista em Londres, especificamente em um terreno que já foi atingido pelo IRA.

Se retomarmos a cena do restaurante, podemos observar que o pai de Chris é descrito por Chloe como um "fanático religioso". Na única vez em que se refere ao pai, o protagonista caracteriza-o como "austero" e revela que seu pai foi morto em combate por conta de suas convicções religiosas, conforme podemos inferir da frase: “após perder as duas pernas, [meu pai] encontrou Jesus". A avaliação negativa de Chris sobre o engajamento de seu pai faz-se

\footnotetext{
109 "Na sexta-feira, 10 de abril de 1992, uma bomba do IRA explodiu uma van estacionada em frente ao Baltic Exchange. Três pessoas morreram, incluindo um funcionário do Baltic. A bomba destruiu o Baltic e os escritórios de grandes empresas que ficavam no prédio, inviabilizando a continuidade do pregão. Na segundafeira pela manhã, o Baltic Exchange foi transferido para o banco Lloyd's e na quarta-feira, o pregão foi reaberto. O Baltic Exchange não conseguiu reconstruir o 30 St Mary Axe incorporando seus elementos históricos, conforme exigido pelo English Heritage [órgão do governo responsável pelo patrimônio inglês], o terreno foi vendido para a Trafalgar House, em 1995. Disponível em: <http://www.balticexchange.com/default.asp?action=article\&ID=395 >. Acesso em: 13 jan. 2010.

${ }^{110}$ A controvérsia em torno da construção do Swiss Re é relatada na apresentação do Baltic Exchange: "Este é o famoso prédio que ocupava o local do 'pepino erótico' de Norman Foster no centro financeiro de Londres. Conforme observado recentemente por um oficial de conservação: "se você quiser uma autorização para demolir um edifício tombado pelo governo, encontre um renomado arquiteto para fazê-lo". O Baltic Exchange foi construído em 1903, por Smith e Wimble. O edifício foi pensado para demonstrar a riqueza e magnificência, para não dizer solidez, do comércio marítimo londrino. Não se trata de arquitetura de ponta, mas remete ao auge da época da Rainha Vitória e do Império. Em 1992, sua estrutura foi danificada pelo ataque a bomba promovido pelo IRA. A intenção do governo era reconstruir o Exchange, mas interesses comerciais se sobrepuseram e, em 1998, John Prescott permitiu que ele fosse demolido”. Disponível em: <http://www.heritage.co.uk/apavilions/baltic.html>. Acesso em: 13 jan. 2010.

111 "O Baltic Exchange agora consiste em peças, divididas em um grande número de caixas de madeira que ficam guardadas em uma granja perto de Canterbury. Desmontá-lo, catalogá-lo e deslocá-lo custa por volta de 4 milhões de libras. Ele está à venda como um kit de Lego glorioso, pronto para montar uma elegante casa de campo, ou uma sede magnífica de empresa, ou apenas um conjunto de edifícios de escritório para um homem rico. É composto por granito vermelho, apresenta cor de mármore e contém pedras Portland. Os interiores de gesso estão intactos, repletos de monstros marinhos, golfinhos e sereias, entre os moldes clássicos. Não é mais tombado (era Grade II) e como, oficialmente, não existe mais, você resolve o que fazer com ele." Disponível em: <http://www.heritage.co.uk/apavilions/baltic.html>.Acesso em: 13 jan. 2010.
} 
presente também no discurso do protagonista, o qual disserta aos irmãos Hewett que a "fé é o caminho da menor resistência". Chris retoma o discurso da sorte, apresentado no prólogo, para impressionar os presentes: "Parece que os cientistas estão confirmando que toda a existência está aqui por acaso, sem propósito, sem projeto.” A contrapelo do protagonista, partindo da informação de que Chris é irlandês, a "ausência de propósito, de projeto" apresentada é ainda mais sentida. Trata--se do apagamento das possibilidades de mudança e de luta dos irlandeses contra o império britânico. Em artigo sobre o contexto político contemporâneo na Irlanda, Ellen Hazelkorn e Henry Patterson argumentam que “(...) o que sobrou da classe trabalhadora e dos movimentos radicais, que o Partido dos Trabalhadores [Workers' Party] representava nos anos 1980, foi continuamente enfraquecido pelo desemprego em massa e pela emigração, pela competição internacional e as demandas competitivas, e pelo novo-corporativismo"112.

Em um país dividido entre protestantes e católicos e marcado por conflitos armados pela luta pela independência do império britânico, o fato de um irlandês, filho de um "fanático religioso" ser recebido pela elite britânica, favorecido e promovido a alto executivo em uma das mais importantes corporações do mundo, uma empresa de resseguros ${ }^{113}$ não é contingente $^{114}$. A entrada de Chris no Swiss Re faz-se sobre as ruínas dos ataques do IRA contra o império britânico, escondidas sob o imponente edifício ${ }^{115}$. Nesse sentido, vejamos como a entrada do protagonista no Swiss Re é composta.

\footnotetext{
${ }^{112}$ Ver: Hazelkorn, Ellen; Patterson, Henry. "The New Politics of the Irish Republic". In: New Left Review I/207, September-October, 1994, p.68.

113 "Fundada em 1863, em Zurique, na Suíça, a Swiss Re opera em mais de 20 países e fornece os seus conhecimentos e serviços a clientes de todo o mundo. Os tradicionais produtos de resseguros da $S w i s s$ Re es serviços relacionados à propriedade e desastres, bem como as empresas de saúde são complementados por um seguro baseado em soluções financeiras corporativas e serviços complementares para a gestão global do risco." Disponível <http://www.swissre.com/pws/about\%20us/swiss\%20re\%20at\%20a\%20glance/swiss\%20re\%20at\%20a\%20glan ce.html>. Acesso em: 1 fev. 2010.

${ }^{114}$ De acordo com Hazelkorn e Patterson, “o partido Trabalhista [Labour Party] utiliza a sua relação específica com os sindicatos para prosseguir com a reestruturação econômica convencional e o desmantelamento do Estado de bem-estar social dentro dos interesses do capital". Ver: Hazelkorn; Patterson, op.cit., p.66.

115 Não é apenas sob as ruínas dos ataques do IRA que o arquiteto britânico Norman Foster, responsável pelo "The Swiss Re" londrino, atua. Foster é um grande conhecido dos nova-iorquinos, ele é um dos arquitetos envolvidos no projeto de reconstrução do World Trade Center, e também foi o responsável pelas reconstruções da Hearst Tower, em Manhattan, e da City Library. Foster é um dos mais prestigiados arquitetos da atualidade (ganhador do prêmio Pritzker, em 1999, o mais importante prêmio de arquitetura), dentre os seus projetos destacam-se o maior aeroporto do mundo, construído em Pequim, na China para os Jogos Olímpicos de 2008. Sobre a reconstrução de prédios antigos, o arquiteto britânico é definido como "especialista em inserir um design contemporâneo em prédios históricos". Disponível em: <http://www.nytimes.com/2008/10/23/arts/design/23libr.html>. Acesso em: 1 fev. 2010. O estilo de Foster ganhou projeção internacional nos anos 1970, "ele foi um dos mais famosos praticantes de uma arquitetura
} 
Como é comum na obra de Allen, a apresentação é primeiro do edifício, depois dos personagens. Ouvimos a voz over: "Bom dia, Chris Wilton.", mas não temos acesso ao seu foco emissor. A imagem estampada na tela é a do Swiss Re, não de Chris, o que já indica que o espectador deve fazer a associação entre o protagonista e o edifício. Ao entrarmos no interior do prédio, a conversa entre Chris e Rod Carver [Simon Kunz] transcorre normalmente: "Você vai trabalhar sob as ordens de Alan Sinclair", ou seja, não há nenhuma dúvida de que Chris será contratado. A ideia de uma entrevista de emprego, anterior à contratação (como ocorreu no Queen's), nem sequer é posta em questão durante a cena no Swiss Re. O currículo dá lugar aqui ao favor explícito. Rod e Alan estão apenas cumprindo ordens do dono da companhia:

[Rod Carver]: "Em um primeiro momento, você pode achar o trabalho um pouco desestimulante, mas isso logo vai passar assim que você perceber como as coisas transcorrem por aqui."

[Chris Wilton]: "Claro, claro."

[Alan Sinclair]: "É basicamente das nove às cinco."

[Rod Carver]: "Então, você terá tempo de sobra para manter o seu backhand, se quiser."

Por meio do uso da câmera circular, Allen muda o foco de nossa atenção que não está no diálogo, mas no edifício. O percurso, feito pela câmera, oferece uma visão panorâmica do escritório: sem divisórias ou paredes ${ }^{116}$, o departamento é circunscrito por janelas de vidro por todos os lados do escritório. A vista para a cidade e para os outros edifícios de negócios é contínua. Vemos executivos trabalhando em computadores, pessoas em reunião, telefones tocando, ou seja, o escritório está em pleno funcionamento. Depois deste breve panorama, a câmera pára em Chris, Rod e Alan Sinclair [Geoffrey Streatfield] que se cumprimentam. Assim, a pretensa "entrevista de emprego" ganha a exata medida do cargo por indicação.

tecnológica que fetichizava a cultura das máquinas. O seu triunfante edifício bancário Hong Kong e Shanghai, de 1986, concebido como um kit de peças conectado a uma armação de aço foi a resposta do capitalismo ao populista Centro Pompidou, em Paris. Desde então, seu escritório passou de 65 para 700 funcionários". Disponível

em: <http://www.nytimes.com/2006/09/08/nyregion/08towers.html?pagewanted=2\&sq=norman\%20foster\%20and\% 20World\%20Trade\%20Center\&st=cse\&scp=7>.Acesso em: 1 fev. 2010.

116 A Swiss Re Tower (1997-2004) é conhecida como "o primeiro edifício ecológico em Londres, uma construção facilmente reconhecível na paisagem da cidade, a rua Mary Axe ganha uma abordagem radical técnica, arquitetônica, social e espacialmente. Feito em um plano radial, concebido em um projeto de energiaconsciente, o prédio transforma muros e paredes em uma contínua estrutura triangular propiciando espaços livres de colunas, iluminados e oferecendo uma estonteante vista da cidade" Disponível em: <http://www.fosterandpartners.com/Projects/1004/Default.aspx > Acesso em: 1 fev. 2010. 
Vestido como executivo, o professor de tênis, o qual na cena anterior ao lado de Chloe mostrara-se relutante, responde: “O salário não será um problema. Foi um prazer, Alan e Rod". Os executivos se cumprimentam e, em cerca de segundos, Chris é contratado pela empresa da família Hewett. É interessante notar que ao fundo e posicionados de frente para a câmera, outros dois executivos do escritório observam estupefatos a rapidez da contratação (Figura 2).

Conforme procuraremos argumentar, a maneira como o plano é estruturado no filme permite inferir que a inclusão do Swiss Re seria um comentário de Allen sobre a arquitetura contemporânea $^{117}$. Inaugurado em março de 2004, ou seja, durante as filmagens de Match Point, o Swiss Re almejava não apenas ser um prédio de negócios, mas "um ícone instantâneo do Reino Unido no Século $21^{\text {"118 }}$. Nesse sentido, a inclusão de sua imagem propagada pela indústria do cinema contribuiria para a divulgação do edifício. No entanto, argumentaremos que ao situar o protagonista no centro financeiro de Londres em um prédio projetado por um dos maiores arquitetos do star system, Allen cria novamente uma armadilha. Ao mesmo tempo em que incorpora a propagação da arquitetura de marca, a cena inclui a crítica à logotecture.

O Swiss Re seria um exemplar da arquitetura rentista, composto por "imagens arquitetônicas exclusivas, capazes de valorizar os investimentos e, consequentemente, as cidades que os disputam"119. A arquitetura rentista, conforme explica Pedro Arantes referindo-se especialmente às construções de Frank Gehry - busca em suas formas: "quanto mais informe, retorcido, "desconstruído" ou "liquefeito" o objeto arquitetônico, maior seu sucesso de público e, portanto, seu valor como imagem publicitária" ${ }^{\text {120 }}$. Apesar de concentrar-

\footnotetext{
${ }^{117} \mathrm{O}$ interesse de Allen pela arquitetura contemporânea é bastante conhecido e faz-se presente em quase todos os seus filmes, os mais evidentes seriam Annie Hall e Manhattan. No entanto, há uma cena em Hannah e suas irmãs em que os personagens discutem as mudanças na arquitetura nova-iorquina. Assim como em Match Point, em Hannah o espectador deve distanciar-se das opiniões dos personagens para que possa entender a ironia dos diálogos e a crítica subjacente à arquitetura pós-moderna. Em entrevista a Stig Björkman, Allen reafirma o seu interesse por arquitetura:

BJÖRKMAN: Sam Waterston interpreta um arquiteto em Hannah e suas irmãs e em uma cena ele mostra seus prédios prediletos de Nova Iorque para Dianne Wiest e Carrie Fisher. Eles são seus prédios favoritos também?

ALLEN: Alguns deles eu gosto muito, sim. Tenho plena consciência da arquitetura de Nova Iorque e estou muito indignado com os novos edifícios que são construídos sem nenhum respeito pelo contexto em que estão inseridos. Ver: Björkman, op.cit., p.157.

${ }^{118}$ Lane, Megan. "Modern Britain's instant icon". In: BBC News Online Magazine 3/2004. Disponível em: $\langle$ http://news.bbc.co.uk/2/hi/uk_news/magazine/3663971.stm>. Acesso em: 6 jun. 2009.

${ }^{119}$ Arantes, Pedro. "O grau zero da arquitetura na era financeira". In: Novos Estudos CEBRAP, $n^{\circ}$ 80. São Paulo: mar. 2008, p.175.

${ }^{120}$ Arantes, op.cit., p.176.
} 
se na análise das obras de Gehry, "o mais espetacular de todos os arquitetos", Arantes indica que o argumento é válido "para diversas obras dos demais arquitetos-estrelas de hoje - entre eles, [...] o mais high-tech dos arquitetos contemporâneos, Norman Foster (que deixou sua marca definitiva na City de Londres, alterando-lhe totalmente o skyline, ou projetando o maior aeroporto do mundo, em Pequim, na forma de um dragão)"121.

A arquitetura rentista, conforme argumenta Arantes, caminha para "o grau zero da arquitetura, reduzido a um jogo de formas, aparentemente sem regras e limitações de qualquer espécie, em busca do grau máximo da renda [...]"122. O objeto arquitetônico contemporâneo guarda semelhanças com "a ausência de propósito e de projeto", apresentada por Chris Wilton. Esse jogo de formas aparentemente sem regras é o território do pós-modernismo. Pode-se afirmar que o projeto do Swiss Re pertence a essa corrente, pois se apresenta como uma "totalidade em si, desgarrando-se da cidade, de qualquer contexto ou território"123.

Assim como o edifício de negócios, Chris pretende descolar-se de seu contexto, de suas origens, associando-se aos Hewett. O filme o apresenta estabelecendo o paralelo entre o protagonista e a logotecture, cujo "objetivo é a produção da exclusividade, da obra única, associada às grifes dos projetistas e de seus patronos" ${ }^{\text {124 }}$. Apesar da tentativa do protagonista de desgarrar-se de qualquer contexto ou território, o filme reforça o contexto a despeito de Chris.

A aproximação entre o protagonista de Match Point e o repertório do pós-modernismo pode ser observada também na comparação com o filme Zelig (1983), no qual Allen utiliza a linguagem do pós-modernismo para questioná-lo. Após começar a leitura do romance Moby Dick, Leonard Zelig transforma-se em um camaleão humano, adquirindo as características dos outros. Para Allen, o movimento apresentado em Zelig ocorre "quando as pessoas querem ser queridas e sentir-se parte de um grupo de tal forma que elas abandonam sua personalidade no esforço de serem aceitas. Elas querem apenas se adequar. E essa tendência acompanha a pessoa em todos os aspectos da vida, inclusive no político. Isso leva a conformidade extrema e a submissão total às vontades e necessidades de uma personalidade forte" ${ }^{\text {"125 }}$. Para o diretor, o filme traz "o resultado final de desistir da própria personalidade, o sentimento de ser capaz

\footnotetext{
${ }^{121}$ Ibid., p.192.

${ }^{122}$ Ibid., p. 176.

${ }^{123}$ Ibid., p. 189.

${ }^{124}$ Ibid., p. 180 .

${ }^{125}$ Björkman, op.cit., p.141.
} 
de se misturar para se proteger, como faz um camaleão com o seu entorno. É o material perfeito a ser liderado pelo poder persuasivo fascista. E eles contavam exatamente com isso."126. Allen explica que sempre quis tratar Zelig como um "fenômeno internacional [...] como se ele fosse uma figura internacional famosa" ${ }^{\prime 27}$.

A incorporação de aspectos do pós-modernismo nos filmes de Woody Allen foi bastante discutida pela crítica, em especial nas análises que se ocupam do filme Zelig cuja temática associa-se diretamente ao pós-modernismo. Para Christopher Beach, Woody Allen é considerado "um típico cineasta pós-moderno"128 cujos filmes seriam "híbridos", uma espécie de "comédia pós-moderna", nos quais o uso da "paródia ou pastiche, de citações, e da encenação auto-consciente ou auto-reflexiva utilizada em gêneros tradicionais de Hollywood, tem o propósito de ironizar tanto os códigos sociais contemporâneos quanto os códigos específicos de produção hollywoodiana" ${ }^{\text {129 }}$. A investigação de Beach sobre a obra de Allen caminha no sentido de entender a fundamental questão das classes sociais nos filmes do diretor. Para isso, Beach argumenta que os personagens de Allen, em geral, apresentam "uma ausência de capital cultural adequado" ${ }^{130}$. A respeito de Zelig, o crítico considera que se trata da representação de uma sociedade sem classes: "o filme mostra a dissolução das fronteiras de classe, e pode ser lido como uma alegoria da ruptura pós-moderna de identidade de classe. Zelig não é mais sujeito de uma determinada rede de identidade de classe, mas é definido apenas em relação àqueles com quem ele entra em contato. Por se apropriar quase imediatamente das características sociais, padrões de fala, e opiniões das pessoas ao seu redor, Zelig torna-se o símbolo de uma sociedade sem classes"131.

Em ensaio sobre Zelig, Robert Stam e Ella Shohat retomam a questão do pósmodernismo: “À primeira vista Zelig poderia dar a impressão de partilhar de certas características do pós-modernismo neoconservador: um estilo enraizado em pastiches, o historicismo eclético de textos reciclados, a visão da disponibilidade do passado apenas enquanto representação estereotipada, uma espécie de ironia em branco. Mas apesar de a personagem Zelig, pelo menos em sua fase camaleônica (e poder-se-ia dizer que Zelig nunca abandona sua fase camaleônica) representar de fato o pós-moderno, já não se pode dizer o

\footnotetext{
${ }^{126}$ Ibid., p. 141

${ }^{127}$ Ibid., p. 136.

${ }^{128}$ Beach, op.cit., p.156.

${ }^{129}$ Ibid., p. 157.

${ }^{130}$ Ibid., p. 164 .

${ }^{131}$ Ibid., p.172-173.
} 
mesmo do filme Zelig. Não se trata de uma trivialização da história, como se chegou a dizer do filme. Em nossa opinião, o que Zelig faz é lançar uma certa luz na natureza construída e manipulável da história enquanto disciplina mediada pela indústria cultural. Ainda que se tratasse de exagero dizer que Zelig é um exemplo do que Hal Foster chama de "pósmodernismo de oposição", é possível discernir uma leitura oposta e antecipatória do que, em alguns aspectos, vem a ser um texto recalcitrante."132.

No tocante às relações de classe, Stam e Shohat apontam no personagem Zelig "uma fraqueza pela ascensão social e um fascínio pela possibilidade de transitar livremente entre fronteiras e de ganhar acesso aos verdadeiros centros do poder." ${ }^{\prime 13}$ Nesse sentido, o que em Zelig era apenas sugerido e talvez secundário, em Match Point ganha contornos claros de uma sociedade de classes. Diferentemente de Zelig que "faz tanto o pária quanto o novo-rico; ele é tanto aristocrata trocando ideias nos jardins de sua propriedade quanto povão batendo papo com a empregada na cozinha"134, Chris Wilton abandona sua origem pobre aliando-se aos Hewett. Nesse ponto, retomaremos a análise detalhada do filme.

Após a contratação do professor de tênis pela Hewett Inco., Chris e a jovem herdeira comemoram a entrada do protagonista na empresa da família. Em agradecimento pelo emprego, Chris presenteia a namorada com uma coletânea de ópera. Nesse ponto, o espectador notará a utilização da ópera no filme como objeto de distinção. Os irmãos Hewett apreciam o interesse do protagonista por música clássica. Na primeira oportunidade em que Chris revelou seu interesse por ópera (no Queen's Tennis Club), o professor de tênis foi convidado por Tom para o camarote dos Hewett no Royal. Desta vez, ele presenteia Chloe com uma coletânea. Enquanto abre o presente, a jovem herdeira traça o destino do irlandês: “Acredite em mim, em pouco tempo você estará chefiando aquela divisão." O aspecto do cargo por influência evidencia-se. A justificativa apresentada pela herdeira Hewett indica a ascensão do recém-contratado: "Você é muito mais inteligente do que o Alan Sinclair. Ele é legal, mas sem inspiração." O "brilho" do tenista e, especialmente, o namoro com a jovem dona da empresa fazem com que o funcionário antigo seja dispensado para a promoção do protagonista. As relações de favor explicitadas no filme durante a contratação de Chris, feita no ícone da arquitetura rentista, retomam a ideia de que na "mundialização financeira, formas

\footnotetext{
${ }^{132}$ Stam; Shohat, op.cit., p.141.

${ }^{133}$ Ibid., p.133.

${ }^{134}$ Ibid., p.133-134.
} 
modernas e arcaicas seguem se articulando, mas com sinal invertido: o rentismo passa a pólo moderno, e o setor produtivo, a arcaico" ${ }^{\prime 35}$. Apesar de Chloe ter afirmado na cena do restaurante que acredita no esforço e no trabalho, ela promove a ascensão do namorado nas empresas da família, em detrimento do funcionário antigo por intermédio de uma relação arcaica: a jovem herdeira é filha do dono da empresa.

O filme relaciona à predileção as artes à proposta de emprego. Ao descrever o presente ofertado à namorada, o protagonista caracteriza-o como sendo "muito raro, [a coletânea] tem árias lindas, sua voz [a do cantor, provavelmente Enrico Caruso] expressa tudo o que é trágico na vida.” As referências à tragédia, às gravações raras e à voz do cantor ilustre enaltecem as qualidades do protagonista para a família Hewett. Allen contrapõe também, a despeito do protagonista, as distintas visões de mundo entre Chloe e Chris. A jovem herdeira diz que ama a vida e pergunta ao namorado irlandês de origem humilde: "Você a acha trágica, não?" O estrategista Chris, que na cena do restaurante aprendera que quando está ao lado dos Hewett perde o poder de escolha, pergunta: "E você?", como quem verifica primeiro a opinião da jovem herdeira para saber o que deve responder.

Afeita ao showbusiness, Chloe compartilha a mesma reverência às artes que o namorado. Ela propõe a Chris que permaneçam no dormitório do protagonista para jantar e "ouvir a tragédia". Na análise sobre a intervenção corporativa nas artes, Chin-tao Wu esclarece que para os “(...) homens que ascendem ao topo da escala corporativa por meio de uma carreira administrativa, [...] o envolvimento nas artes é uma manifestação na qual estão ancoradas sua condição de elite e suas aspirações de classe." ${ }^{136}$

Nesta cena será importante ressaltar também que a ópera passa de instrumento de distinção utilizado pelo protagonista (no intuito de impressionar os Hewett) para música de acompanhamento entre os personagens. Note-se que a utilização da ópera feita pelos personagens difere do uso da ópera no filme, como instância extra-diegética. À medida que a jovem Hewett abre a garrafa de vinho (da mesma marca que Tom havia pedido no restaurante), o ex-professor de tênis revela suas novas preferências: "Ah, PullignyMontrachet. Eu nunca tinha ouvido falar antes de Tom pedir, agora estou viciado." Nesse ponto, o gosto por artigos consumidos pela classe alta adquire contornos de dependência, apresentado como vício pelo protagonista.

\footnotetext{
${ }^{135}$ Arantes, op.cit., p.192.

${ }^{136} \mathrm{Wu}$, op.cit., p.149.
} 
Assim como na apresentação do Swiss Re, Allen apresenta a fachada do ilustre cinema Curzon Mayfair ${ }^{137}$, onde Chris e Chloe aguardam Tom e Nola. O filme em cartaz é Diários de Motocicleta, do diretor brasileiro Walter Salles. Após a chegada de Tom e o subsequente diálogo entre os personagens, o espectador pode observar que as diferentes opções de cultura, a saber, a ópera cantada pelo tenor italiano, o vinho francês e o filme dirigido pelo cineasta brasileiro igualam-se no filme, apresentando uma mesma função: a de entretenimento para os ricos. Ao chegar ao Mayfair ${ }^{138}$, Tom informa ao casal que Nola não poderá acompanhá-los, por conta de uma "dor de cabeça". Diferentemente de Chris que vai ao cinema para encontrar Nola, Tom desdenha a noiva: "Ela que se dane, vamos assistir a Diários de Motocicleta!". Outro elemento que é retomado nesta cena apresenta a diferença de visões de mundo entre os Hewett e os estrangeiros. A recepção do filme sobre a viagem do revolucionário Ernesto Guevara pela América Latina é vista sob dois olhares: o de Nola, que está ausente, e Chris que quer encontrar a norte-americana; em contraposição ao dos irmãos Hewett. A formação de Guevara, líder da Revolução Cubana, é transformada em espetáculo para os jovens endinheirados. Enquanto Chris lamenta pela ausência de Nola, Chloe ri com o irmão: "Aposto que este filme foi escolha dela, não acredito que você viria."

Em seguida à tentativa frustrada de encontrar Nola, o olhar da câmera retorna para o sofá-cama do protagonista, onde Chris e a namorada repousam. Observa-se o tédio do exprofessor de tênis ao lado de Chloe. A herdeira volta ao assunto do novo emprego de Chris: "Todos gostam de você no trabalho. Papai disse que ouviu muitos elogios. Você é um rapaz muito esperto." O casal ri, há um novo corte no qual vemos o ex-professor de tênis saindo de uma loja de roupas com uma sacola na mão. É possível ler na entrada da loja o nome da marca Ralph Lauren. Chris caminha para a esquina da rua e, casualmente, encontra um

\footnotetext{
137 “O Curzon Mayfair tem sua construção classificada como Grade II e é um dos mais antigos e prestigiados cinemas de arte londrinos. Escolhido pelos leitores da revista Time Out como um dos principais cinemas de Londres, ele reflete os mais altos padrões da produção independente e cinemas de arte internacionais desde que abriu em 1934. [...] O Curzon Myfair foi um dos primeiros cinemas a importar e exibir filmes em língua estrangeira no Reino Unido. [...].” Disponível em: <http://www.curzoncinemas.com/venues/mayfair/history>. Acesso em: 13 jan. 2010. "Mayfair é a nossa joia da Coroa, o nosso baluarte do cinema mundial composto por uma sala palaciana (Screen One) com capacidade para 319 pessoas, incluindo os dois luxuosos camarotes reais e a sala aconchegante (Screen Two) com 83 lugares. Comemorando 75 anos em 2009, Mayfair é o coração da rede de cinemas Curzon, possuindo uma rica história cinematográfica e uma audiência dedicada de interessados em cinema”. Disponível em: <http://www.curzoncinemas.com/\#/venues/mayfair >. Acesso em: 13 jan. 2010.

${ }^{138}$ No filme, Allen localiza os bairros em que as classes altas da capital inglesa vivem e circulam, Chloe afirma ter sido criada no bairro Belgravia, "localizado na parte oeste de Londres é um lugar onde existem muitas casas e lojas caras, além de embaixadas". O local que dá nome ao cinema Mayfair "é a mais rica região de Londres, localizada próxima ao Hyde Park. Mayfair tem muitos hotéis grandes e famosos e foi um lugar muito badalado para se viver, mas muitas das casas foram transformadas em escritórios. Disponível em: <http://www.ldoceonline.com/dictionary/Mayfair>. Acesso em: 13 jan.2010.
} 
conhecido. Ouve-se a voz da personagem antes que ela apareça na tela, mantendo o foco da câmera no protagonista. Nola caminha em sua direção. O protagonista explica à noiva do jovem Hewett que estava procurando por um "suéter do tipo que Tom usa. É cachemira?" Nola esclarece ao tenista que o tecido utilizado por Tom chama-se "vicunha". Na cena explicita-se que Chris procura reproduzir o estilo de Tom. Na comida, no emprego, na ópera, no vinho, no filme e na vestimenta: o ex-professor de tênis quer parecer-se com um Hewett. A montagem rápida das cenas revela os novos atributos do protagonista, entendidos como investimentos: o emprego como executivo, a coletânea de óperas raras, o vinho e as roupas de marca. No filme observa-se movimento semelhante ao descrito por López-Ruiz, no qual $o$ consumo é transformado em um investimento "e, portanto, o consumidor num investidor. Estabelece-se, assim, uma nova relação entre o presente e o futuro. As pessoas capitalizam-se consumindo: "eu consumo hoje para meu futuro"; ou o que acaba sendo o mesmo, "eu postergo minhas satisfações consumindo agora""'139.

Em síntese, a contrapelo da ideologia pós-moderna, o filme caracteriza um tipo social representado pelo personagem Chris Wilton: o sujeito da financeirização como fenômeno hegemônico global. Chris adota a linguagem do empreendedor desde o começo do filme, o protagonista representaria o ethos que permite "fazer do humano uma forma de capital" Chris teria um "conjunto de habilidades, destrezas e talentos que, em função do avanço do capitalismo, adquire valor de mercado e se apresenta como forma de capital - entendido como uma soma de valores de troca que serve de base real a uma empresa capitalista. Assim, a partir de um determinado momento que chamamos de invenção do capital humano, o capital, conceito necessariamente abstrato, passa a se apresentar coberto com roupas humanas; vestindo características e atributos até então apenas vistos no homem. O capital, desta vez, concretiza-se não em dinheiro ou mercadorias, mas em atributos humanos; o capital é investido de formas humanas."141 . Conforme previra Marx em $O$ Capital, o homem passa a ser concebido como coisa, como um produto. Atualmente, argumenta López-Ruiz, cabe ao homem valorizar o seu produto, realizar investimentos para aumentar o seu valor.

$\mathrm{O}$ "conjunto de habilidades, destrezas e talentos" que permitem que Chris desenvolva o seu capital humano e aumente o seu valor como produto, são claramente apresentados pelo filme: as habilidades como tenista, o gosto por ópera e por literatura, além dos atributos que

\footnotetext{
${ }^{139}$ López-Ruiz, op.cit., p. 225.

${ }^{140}$ Ibid., p.26.

${ }^{141}$ Ibid, p. 184 .
} 
Chris copia dos Hewett como as roupas que Tom veste, o vinho que o irmão de Chloe pede, entre outros. Todos esses investimentos ajudam Chris a aumentar as suas "probabilidades de sucesso no próprio marketing pessoal, atividade fundamental e tarefa imprescindível para um capitalista do seu capital humano" 142 . Os Hewett consideram Chris como um bem a ser desenvolvido, os livros que lê, os cursos que faz, as ações em que investe, os espetáculos e filmes que assiste, a comida, as roupas, o vinho, o emprego, a concepção do filho, tudo é monitorado pela família.

No entanto, pondera López-Ruiz, "para que o capitalismo consiga continuar se desenvolvendo - e possa ir além de sua atual fronteira de expansão - é necessário que o empreendedorismo não seja apenas a particularidade de uns poucos, mas o atributo de um povo. Essa, talvez, seja a característica mais marcante do espírito do capitalismo hoje: o empreendedorismo precisa ser um fenômeno de massas." ${ }^{143}$, o que explica a identificação do espectador com o protagonista e amplia o escopo de diagnóstico do filme, o tipo social representado por Chris revela o espírito do capitalismo contemporâneo. A maneira como está estruturado o foco narrativo expõe o protagonista e coloca o seu estatuto em questão, permitindo ao espectador ver que se trata de um "trabalhador que precisa investir o tempo todo (consumindo) para garantir (sem garantias) sua posição social; alguém que precisa garantir (sem garantias) que continuará sendo aquele feliz indivíduo individual que imagina que é"144.

\footnotetext{
${ }^{142}$ Ibid., p.225.

${ }^{143}$ Ibid., p. 261

${ }^{144}$ Ibid., p.307.
} 


\title{
Capítulo II - Aliança de classes
}

\subsection{Dinheiro, jogo e prostituição}

\begin{abstract}
"Não haverá uma determinada estrutura do dinheiro, que somente no destino se faça reconhecer, e uma determinada estrutura do destino, que se faça reconhecer apenas no dinheiro?"

Walter Benjamin, "Jogo e prostituição".
\end{abstract}

O mundo do trabalho corporativo aparece relacionado ao ambiente do jogo neste filme. Há uma associação entre as finanças e o jogo, cifrada na figura do protagonista - que de ex-jogador profissional de tênis torna-se executivo de uma grande corporação transnacional. Observa-se também na própria tessitura do filme o elemento do acaso. Pode-se pensar que ao dar ênfase ao acaso, Match Point apresentaria o destino de Chris como inexorável, corroborando à ideia do jogo na qual, conforme exposto por Adorno e Horkheimer: "O acaso e o planejamento tornam-se idênticos porque, em face da igualdade dos homens, a felicidade e a infelicidade do indivíduo - da base ao topo da sociedade perdem toda significação econômica. O próprio acaso é planejado; não no sentido de atingir tal ou qual indivíduo determinado, mas no sentido, justamente, de fazer crer que ele impere. Ele serve como álibi dos planejadores e dá a aparência de que o tecido de transações e medidas em que se transformou a vida deixaria espaço para relações espontâneas e diretas entre os homens" ${ }^{145}$. Porém, conforme demonstramos no primeiro capítulo, o destino de Chris é "sem garantias". Apesar de ter recebido a oferta de emprego isso não significa que o jogo está decidido de antemão. Se o "jogo invalida as ordens da experiência"146, o filme, por sua vez, a despeito do discurso do protagonista, revela as escolhas de Chris. Diferentemente do jogador, o filme inclui a interpretação do acaso. Isso posto, vejamos em detalhe, como o filme incorpora o jogo como material, apresentando a todo o momento sua significação econômica e associando-a ao capital financeiro.

Em uma rua de lojas caras da cidade, o protagonista encontra Nola. Se por um lado a cena afirma o acaso, pois se trata de um encontro fortuito, por outro, o filme indica que o

\footnotetext{
145 Adorno, Theodor; Horkheimer, Max. “A Indústria Cultural”. In: Dialética do Esclarecimento: fragmentos filosóficos / Theodor W. Adorno, Max Horkheimer; trad. Guido Antonio de Almeida. Rio de Janeiro, Jorge Zahar Ed., 1985, p.120-121.

${ }^{146}$ Benjamin, Walter. Charles Baudelaire um lírico no auge do capitalismo. São Paulo: Brasiliense, 1989, p.130.
} 
encontro não é feito em um lugar eventual. Trata-se, pelo contrário, de uma rua repleta de lojas de marcas famosas, local que os dois frequentam e que une Nola e Chris enquanto consumidores. Em Match Point, haverá uma reiteração de ruas como essa, conforme será mostrado ao longo do trabalho. Nesse ponto, do encontro casual na rua da cidade, Chris compra um suéter parecido com "os que Tom usa”. Por sua vez, Nola está em meio a uma crise nervosa: "Farei um teste em dez minutos e como sempre minha confiança que começou no dez está agora zero." O ex-professor de tênis, que nas cenas anteriores mostrara seu interesse em reencontrar Nola, oferece "apoio moral" e acompanha a jovem atriz ao Royal Court Theatre ${ }^{147}$, local em que ela fará um teste de atuação.

Enquanto Chris aguarda Nola em frente ao teatro, a música extra-diegética retorna ao filme. A interpretação de Caruso da ópera I Pescatori di Perle, do compositor francês Georges Bizet, ilustra os pensamentos do protagonista. A ária escolhida por Allen, "Mi par d'udir ancora", aborda o momento em que o pescador Nadir reencontra sua amada, a virgem protetora dos pescadores Leila ${ }^{148}$, após uma longa separação. Desse modo, a música de Bizet, na qual Nadir canta como um "cisne apaixonado" por ter reencontrado Leila, ilustra o reencontro entre Nola e Chris.

Se a utilização da música extra-diegética neste caso "romantiza" os pensamentos de Chris, a imagem do monumento em homenagem aos mortos pela guerra, em frente ao Royal Court Theatre, insere a ideia de um conflito. No momento em que Nola aproxima-se da câmera e de Chris, a atriz norte-americana conta que não passou no teste: "Foi um desastre". A expressão em inglês utilizada por Nola ressalta a ideia de guerra. Ela utiliza "blew that" o que reitera o sentido de uma "explosão", presente tanto no Royal Court Theatre, que foi atingido por uma bomba durante a Segunda Guerra Mundial, como no monumento pelos

\footnotetext{
147 “O Royal Court Theatre foi construído no lado leste da Sloane Square. Inaugurado em 1888, ele substitui o antigo Court Theatre que ficou conhecido também como the New Chelsea Theatre e Belgravia Theatre. Durante a Segunda Guerra Mundial, o Royal Court Theatre foi atingido e danificado por uma bomba. O interior do teatro foi reconstruído por Robert Cromie e reaberto em 1952. Outras alterações foram feitas em 1956 e 1980, mas a fachada permaneceu em grande parte inalterada. Muitas das peças de George Bernard Shaw foram produzidas no Royal Court. O teatro criou uma nova geração de dramaturgos britânicos, tais como: John Osborne, John Arden, Ann Jellicoe, entre outros. No teatro foram incluídas as primeiras temporadas das peças internacionais de Bertolt Brecht, Eugene Ionesco, Samuel Beckett, Jean-Paul Sartre e Marguerite Duras. O Royal Court é conhecido como inaugurador do drama moderno britânico, incentiva a produção de novos dramaturgos e recebe residências artísticas internacionais." Disponível em: <http://www.british-history.ac.uk/report.aspx?compid=28709\#s9>. Acesso em: 3 mar. 2010.

148 "A virgem Leila e o pescador Nadir se reconhecem e ele a contempla embevecido enquanto ela sobe o penhasco. Numa ária de grande beleza, o jovem evoca um amor que o tempo não pode apagar [...]. É a passagem mais conhecida da partitura - especialmente na versão italiana, "Mi par d'udir ancora" -, impregnada, como o dueto para o tenor e o barítono e o dueto de amor, de uma espécie de transportamento hipnótico, delicado e sedutor, musicalmente evanescente, mas ao mesmo tempo irresistível.” Ver Kobbé, op.cit., p.445.
} 
mortos da guerra, construído em frente ao teatro em homenagem às vítimas da guerra. Nesse ponto, pode-se retomar a maneira conforme Tom caracterizara Nola como uma "struggling actress" ${ }^{\prime 149}$, resgatando o sentido de luta no trabalho da atriz.

Assim como a fachada do teatro e o monumento pelos mortos da guerra, a derrota de Nola, que não foi aceita para o papel, contrasta com a ópera e os pensamentos de Chris. A música extra-diegética é quebrada pelo barulho de carros que passam pela rua. Nesse momento, Nola diz ao protagonista que costuma beber para se "recompor um pouco". A atriz norte-americana é conduzida por Chris. Em um corte rápido, Nola aparece no bar embriagada. A atriz está sem o blazer preto, com um cigarro na mão esquerda e de camisa branca (o paralelo é novamente estabelecido com a cena do jogo de pingue-pongue):

[Nola Rice]: "O que eu dizia? Minha irmã fez faculdade por alguns anos, mas eu sou como você, autodidata. Devia ver minha irmã, ela é muito bonita, mas se afundou nas drogas." você."

[Chris Wilton]: "Tenho certeza de que ela não é mais bonita do que

[Nola Rice]: "Eu sou sexy. Mas a Linda, minha irmã, tem uma beleza clássica." homens?"

[Chris Wilton]: "Então você sabe que chama a atenção dos

[Nola Rice]: "Antes dos meus pais se separarem, eles a colocavam em uns concursos. Era uma piada."

[Chris Wilton]: "O que o seu pai fazia?"

[Nola Rice]: "Ele... foi embora e nunca mandou dinheiro. Minha mãe não conseguia ficar em um emprego."

[Chris Wilton]: "Não?"

[Nola Rice]: "Não, o problema dela era a bebida."

De forma similar a Nemorino na ópera $O$ Elixir de Amor, Nola embriaga-se com o vinho. Sob o efeito do elixir, a jovem atriz norte-americana revela sua história: nem ela nem a irmã completaram o ensino superior, sua mãe bebia, a irmã é dependente de drogas, o pai fugiu de casa e "nunca mandou dinheiro". Vê-se aqui a diferença entre Nola e Nemorino, enquanto o último se declara para a amada, a primeira revela seus problemas familiares/financeiros. Diferentemente de Chris, que fornece raras informações a seu respeito e tenta imitar os jovens ricos, Nola expõe sua vida ao adversário. Nesse ponto, Chris

\footnotetext{
${ }^{149}$ A expressão struggling actress, utilizada por Tom para caracterizar o trabalho de Nola como atriz, tem em inglês tanto o significado de um trabalhador que "tende a falhar, mesmo quando ele se esforça muito", quanto o sentido explícito de luta. Em inglês, struggle aparece também na expressão class struggle (luta de classes). Disponível em: <http://www.ldoceonline.com/search/?q=struggle>. Acesso em: 3 mar. 2010.
} 
assemelha-se ao charlatão Dulcamara que aproveita da embriaguez de Nemorino para lucrar com a venda do elixir.

A jovem atriz sabe que conquistou Tom por seus dotes físicos: "Nos conhecemos em uma festa. Tom me viu na sala e veio na minha direção como um míssil. E eu gostei dele na hora. Eu pensei... Bem, eu acho que ele é bem bonito. Você não acha?” A aproximação de Tom é descrita por Nola revelando não apenas a atração física entre os dois como também o espírito belicoso na abordagem feita pelo jovem Hewett. Nola descreve a aproximação de Tom utilizando uma imagem essencialmente bélica, "a guided missile" míssil retoma a ideia de uma guerra, sugerida pelo monumento em frente ao Royal Court Theatre. E de certa forma, antecipa a maneira pela qual Nola será morta por Chris (atingida por uma bala de espingarda). O míssil relembra também o formato do Swiss Re, edifício construído em formato de ogiva.

É importante notar nesta cena que não se trata apenas de um jogo reafirmado pela utilização do campo/contra-campo, mas do domínio do tenista em relação à jogadora de pingue-pongue. Chris está mais ao lado/no campo de batalha dos Hewett do que Nola, conforme a própria atriz revela. Nola sabe exatamente sua condição na família. A mãe de Tom não aprecia a sua entrada para a família que se dá por meio da beleza. O jogador profissional aproveita a embriaguez da atriz para descobrir como ela conseguiu o noivado com o jovem Hewett (informação crucial para o protagonista que é apenas namorado de Chloe): "Bem, ele encheu-me de presentes e, você sabe, o que eu sei sobre esse tipo de vida? Sou apenas uma atriz faminta de Boulder, Colorado. Mas eu já tive um casamento ruim. Esta é outra razão pela qual ela me odeia." À maneira de um estrategista, Chris recolhe informações não apenas sobre a família de Nola e a fraqueza que a atriz tem com bebida, como também sobre os Hewett, conforme Nola revela: "Eleanor, a mãe do Tom. Ela quer que ele se case com uma garota chamada Olívia, acho que é uma prima distante. Não sei, é doente, eles casam entre si."

Posteriormente ao aviso de Nola de que se trata de uma família que transmite a propriedade por meio do casamento, preservando uma mesma linhagem (conforme simboliza o Englefield Estate), Chris pergunta: “E foi amor à primeira vista para você também?" Nola retoma a atração física: "Eu o achei muito bonito. E como disse, nunca recebi tanta atenção. E

\footnotetext{
150 "A guided missile" é uma expressão usada apenas para caracterizar um "míssil guiado eletronicamente quando está voando". Disponível em: <http://www.ldoceonline.com/dictionary/guided-missile>. Acesso em: 3 mar. 2010.
} 
quanto a você e Chloe?" O protagonista, que mantém as aparências, tenta não comprometerse: "Ela [Chloe] é muito doce." Nola chega a repetir a fala do protagonista, como quem desconfia da afirmação.

Assim como o tenista, a jovem atriz norte-americana teve acesso à família aristocrática inglesa por intermédio de seus dotes físicos. Outro fator que contribuiu para a aproximação entre a jovem do Colorado e a classe alta britânica foi o contato de Nola com o mundo do showbusiness. A norte-americana atuou em comerciais, circulou em festas, participou de eventos que unem entretenimento a grandes empresários e patrocinadores das artes, onde conheceu o noivo. Fica claro nos comentários da família Hewett que a entrada da norteamericana deve-se à sua inserção no mundo do cinema ${ }^{151}$. Chloe chega a afirmar: "Tenho certeza de que a mamãe não implicaria com o maiô da Nola se soubesse que ela usou em um filme", "Nola é atriz, eles são emotivos.", "Tenho certeza de que foi a Nola quem escolheu o filme e não você [,Tom].” Apesar de, assim como o protagonista, apresentar os dotes físicos a seu favor, Nola não faz como o tenista que, para agradar à família, transforma-se em executivo.

Chris lembra que Eleanor também não aprovaria a união entre ele e Chloe. Mas Nola sabe que suas chances de entrada para família Hewett são distintas em comparação a Chris: "Eu não gosto da Eleanor e ela sabe disso, mas você está sendo preparado para o casamento. Guarde as minhas palavras. Eles quase morreram quando pensaram que a Chloe tinha fugido com um cara que trabalhava em um gastropub na City. Você se dará muito bem, a menos que estrague tudo." O palpite de Nola interessa o protagonista: "E como eu faria isso?" A jogadora verte outro gole de vinho e afirma: "Tentando dar em cima de mim."

A provocação entre os jogadores está cifrada na chave do desejo, Nola e Chris incitam um ao outro: "E por que você acha que isso aconteceria?" Nola desafia o protagonista, assemelhando-o à maioria dos homens: "Os homens sempre ficam pensando... Eles acham que eu seria alguma coisa muito especial." Chris provoca a jogadora: "E você é?". Parodiando o jogo rápido de pingue-pongue, reforçado pela utilização do campo/contra-campo, a norteamericana rebate: "Nunca ninguém pediu o dinheiro de volta." O tenista ri e se mantém no

\footnotetext{
${ }^{151}$ O próprio Allen foi beneficiado pelo interesse da família Benyon, os atuais proprietários do Englefield Estate, em permitir as filmagens de Match Point na residência. Em entrevista sobre o uso de sua casa como locação para filmes, Benyon afirmou que a "família tem muitas ofertas de filmagens no local, mas que os horários de filmagem devem agradá-los. As filmagens devem respeitar as férias escolares de meus filhos. Eu achei essa experiência muito emocionante." Disponível em: <http://www.newburytoday.co.uk/News/Article.aspx?articleID=6234 >. Acesso em: 13 jan. 2010.
} 
jogo: “Onde estava toda essa confiança quando você precisou dela no teste de atuação?" Nola encerra a partida: "Eu bebi demais. Pode chamar um táxi?"

A própria fala da personagem estabelece a relação entre o dinheiro e a prostituição: "Nunca ninguém pediu o dinheiro de volta", diz a norte-americana para o ex-professor de tênis. Nola conta a Chris que Tom encheu-a de presentes. Ela afirma "Nunca ter recebido tanta atenção". Nesse ponto, exporemos a relação a partir das análises de Simmel, Benjamin e Schwarz. Em uma passagem onde analisa a "típica relação entre o dinheiro e a prostituição" ${ }^{\text {152 }}$, Georg Simmel analisa a diferença entre o cliente que presenteia a prostituta com dinheiro e aquele que lhe oferece um presente: "Somente uma transação monetária corresponde ao caráter de uma relação fugaz completamente inconsequente como é o caso da prostituição. O relacionamento é completamente dissolvido e mais radicalmente rescindido mediante pagamento em dinheiro do que com um presente de um objeto específico, que sempre, por meio de seu conteúdo, sua escolha e seu uso, retém um elemento da pessoa que lhe deu."153 A partir das reflexões de Simmel sobre as relações entre o dinheiro e a prostituição, Walter Benjamin, na análise sobre Baudelaire, contribui ao mostrar que o dinheiro não pode ser considerado apenas como um meio de pagamento ou como um presente: “O amor da prostituta é, sem dúvida, venal. Mas não a vergonha de seu cliente. Essa vergonha procura um esconderijo para um quarto de hora, e acha o mais genial de todos: o dinheiro. São tantas as nuances do pagamento como as nuances do jogo amoroso - lento ou rápido, furtivo ou violento. $\mathrm{O}$ que quer dizer isto? A ferida rubra de vergonha no corpo da sociedade segrega dinheiro e se cura. Ela se cobre de escaras metálicas. Deixemos ao roué [sabido] o prazer barato de se acreditar impudente. Casanova bem o sabia: o atrevimento lança na mesa a primeira moeda; a vergonha cobre cem vezes a aposta, para não vê-la." ${ }^{\text {154 } \mathrm{A}}$ relação entre o dinheiro e a prostituição é retomada por Roberto Schwarz na análise sobre o romance $O$ pai Goriot, de Balzac. De acordo com Schwarz, "O dinheiro e a prostituição coincidem na equivalência geral que estabelecem. Tudo vale tudo, tanto faz um como o outro, e todos valem todos. Não obstante, é preciso distinguir: a equivalência universal é conquistada pelo dinheiro, mas é sofrida pelos homens, que prostituem suas inclinações por

\footnotetext{
${ }^{152}$ Simmel, Georg 1858-1918. In: The philosophy of money / Georg Simmel; transl. by Tom Bottomore and David Frisby from a first draft by Kaethe Mengelberg. London: Routledge, 1991, p.376-380.

${ }^{153}$ Simmel, op.cit., p.376.

${ }^{154}$ Benjamin, op.cit., p.240.
} 
várias formas, dentre as quais a física é a mais crassa." ${ }^{155}$ Schwarz lembra ainda que o que o dinheiro esconde é precisamente as formas de sociabilidade baseadas na violência: "Uma vez legalizada, com nome de ordem social, a violência se repete através de inumeráveis perfis apenas parciais: a contingência cotidiana de atender à solicitação caótica do mercado evoca a grande expropriação originária, que é seu fundamento.",156

A própria composição dos personagens Chris e Nola é feita de modo que eles apareçam como objetos de consumo. Na casa de campo, os dotes físicos de Chris e Nola são apresentados. O protagonista mostra aos irmãos Hewett sua habilidade na quadra de tênis, Nola destaca-se na mesa de pingue-pongue. No filme, a permanência de Chris na família Hewett aparece condicionada à gravidez de Chloe, após o casamento. O cultivo dos dotes físicos e esportivos do protagonista é reiterado pelos personagens ao longo da narrativa. A relação entre Chris e Chloe retoma aspectos do "casamento por dinheiro" 157 que, de acordo com Simmel, configura-se como uma variação da prostituição: "O casamento por dinheiro, como um meio permanente da prostituição de si mesmo, degrada qualquer parceiro que é motivado pelo dinheiro; independentemente se ele for do sexo masculino ou feminino. [...] Aqui, como em muitos outros casos, a qualidade característica das relações por dinheiro é exibida, ou seja, a superioridade potencial de uma das partes leva à exploração radical e até mesmo à aniquilação do outro." 158

Em Match Point, as relações interpessoais se fazem mediadas pelo dinheiro, o que explica a reiteração das lojas, clubes, casas de campo e outros locais ligados à propriedade e às compras. No sistema de personagens exposto no filme, as qualidades pessoais são transformadas em mercadorias.

\subsection{Recursos épicos}

"O teatro épico interessa-se principalmente pelas atitudes que as pessoas adotam uns com os outros, sempre que elas são sociohistoricamente significativas (típicas). Ele trabalha as cenas em que as pessoas adotam atitudes de tal sorte que as leis sociais sobre as quais elas estão agindo saltam à vista. Para isso, precisamos encontrar definições práticas: ou seja, tais definições dos processos pertinentes podem ser utilizadas como intervenção direta nos processos. O interesse do teatro épico é, portanto, eminentemente prático. O

155 Schwarz, Roberto. "Dinheiro, memória, beleza (O pai Goriot)". In: A Sereia e o desconfiado. Paz e Terra, 1981, p.167-168.

${ }^{156}$ Ibid., p.168.

157 Simmel, op.cit., p.380.

${ }^{158}$ Ibid., p.381-382. 
comportamento humano é mostrado como alterável, o próprio homem é visto como dependente de certos fatores políticos e econômicos e, ao mesmo tempo, como capaz de alterá-los."

Bertolt Brecht, "On gestic music".

Embora não se possa dizer que os recursos utilizados por Woody Allen sejam estritamente épicos, como poderíamos afirmar, por exemplo, dos procedimentos usados por Jean-Luc Godard ${ }^{159}$, observa-se a acomodação de alguns recursos caros ao épico dentro da estrutura narrativa de Match Point. No intuito de identificar esses procedimentos próximos ao épico, retomaremos a ideia de que o filme apresenta os personagens em situação. Na cena seguinte à do encontro entre Nola e Chris no bar, os casais retornam ao Englefield Estate. Em um plano geral da chegada da família à propriedade, observa-se, ao fundo, a igreja ancestral de São Marcos ${ }^{160}$. A câmera está posicionada no muro da propriedade e os empregados aguardam pela chegada da família Hewett. O patriarca é o primeiro a descer do carro, auxiliado pelo motorista. Alec repreende o filho que "está dirigindo muito rápido", enquanto o mordomo da casa ajuda a matriarca a sair do veículo (Figura 3). A governanta recepciona os convidados. A utilização do plano geral nesta cena permite que o espectador estabeleça relações entre a igreja, a casa de campo, os veículos e os empregados. O cenário campestre configura-se como propriedade privada da família Hewett.

$\mathrm{Na}$ estrebaria do Englefield Estate, vê-se novamente a igreja, o que confere a exata sensação ao espectador de que o local de culto religioso pertence à família (o espaço é contíguo, não há muros ou cercas entre a cavalariça e a igreja). O poderio dos Hewett é retomado por meio dos veículos, dos empregados, da igreja e dos cavalos de competição. $\mathrm{Na}$ estrebaria, primeiro ouve-se a voz da herdeira que pergunta por um de seus cavalos. De costas para a câmera, Tom explica à irmã sobre a doença do animal que pode impedi-lo de entrar na

\footnotetext{
159 A aproximação entre Allen e Godard não é absurda, basta lembrar, conforme fizemos na introdução deste trabalho, que Godard fez um filme sobre o cineasta norte-americano buscando identificar justamente a estrutura narrativa nos filmes de Allen.

160 “A igreja de São Marcos (St. Mark's Church) localiza-se ao lado da casa dos Englefield em uma estrada pertencente à propriedade. Frequentemente pode-se observar veados pastando no parque adjacente e de alguma forma, você sente como se estivesse invadindo a propriedade ao entrar na igreja, embora seja um lugar público de culto e até os jardins da casa são abertos ao público durante a semana no verão. Apesar da reconstrução vitoriana, ainda existem inúmeros utensílios medievais na igreja e a família Englefield e os seus sucessores que residem no local ficam, naturalmente, em evidência. A pequena capela de Englefield está repleta de monumentos e até o sepulcro da Páscoa foi reutilizado como um memorial em homenagem ao Sir Thomas Englefield, presidente da Câmara dos Comuns. O monumento a John Paulet, o Marquês de Winchester que defendeu a Basing House durante a Guerra Civil, tem um epitáfio escrito por Dryden." Disponível em: <http://www.berkshirehistory.com/churches/englefield.html>. Acesso em: 13 jan.2010.
} 
competição. Enquanto isso, Nola alimenta um dos cavalos e Chris observa-a. Nesta cena, o filme apresenta os cavalos de competição, outra forma de propriedade dos Hewett, e o crescente interesse de Chris por Nola. A paixão de Chris por Nola será entendida neste trabalho nos termos do conflito entre paixão e equivalência geral, conforme exposto por Schwarz: "Enquanto dura, a fidelidade à fixação individual questiona a base do sistema. Daí o seu interesse escandaloso, semelhante ao que despertam o crime passional e as perversões: faz sentir o que seria da vida se levada a sério; seu mau gosto e caráter excessivo insinuam, pela simpatia paradoxal que despertam, a miragem de uma ordem que não se efetive através do sacrifício dos anseios individuais." ${ }^{, 161}$ Apesar da fixação por Nola, imediatamente o filme apresenta o avesso da paixão: o dinheiro. Na casa de campo, o espectador tem acesso ao lugar onde a família Hewett guarda as armas, outra forma de propriedade. No porão escuro do Englefield Estate, Alec Hewett, ao passo que monta sua espingarda, discorre sobre uma nova proposta ao protagonista relacionada aos negócios: "O que você diria da ideia de fazer um curso de administração pago pela empresa?" A cena permite que o espectador associe o preparo da arma com a conversa sobre o curso de administração entre Alec e Chris. Fica claro aqui que o protagonista é entendido como "um bem a ser desenvolvido" "162 pela família Hewett. Segundo López-Ruiz, essa é uma característica particularmente importante no mundo regido pelo empreendedorismo: "Quando uma pessoa se propõe a ser um melhor produto o que parece estar em questão é de que forma pode ela responder melhor às necessidades do mercado e, portanto, que tipos de investimentos é preciso que ela faça em si mesma e que características ela tem de aprimorar para se tornar efetivamente um melhor produto, um produto melhor posicionado no mercado e, consequentemente, mais vendável: um produto de sucesso." ${ }^{, 163}$ Isso posto, vejamos como essa característica é apresentada em cena.

O protagonista está posicionado no canto direito da tela e olha para o patriarca. Alec está de frente para a câmera. O ex-professor de tênis mostra-se indeciso: "Não sei". O patriarca segura a arma, olha e mira em direção à câmera. Alec prossegue em seu argumento: "Tenho recebido pareceres muito bons a respeito do seu trabalho", ao passo que deixa a espingarda sobre a mesa e passa a limpar os óculos. Ele descreve as vantagens do novo cargo para Chris: "No início do ano que vem, haverá um cargo importante disponível. Uma posição que exige muita responsabilidade e oferece salário compatível”. Alec coloca os óculos e passa

\footnotetext{
${ }^{161}$ Schwarz, 1981, op.cit., p.171.

${ }^{162}$ López-Ruiz, op.cit., p. 267.

${ }^{163}$ Ibid., p.272.
} 
a guardar as balas da espingarda no bolso: "Além disso, existem muitos privilégios... Despesas pagas, motorista etc." O patriarca aproxima-se do protagonista, bate no ombro do ex-professor de tênis e explica, em voz baixa: "Estávamos pensando em outra pessoa, mas é óbvio para mim que você e a Chloe se tornaram íntimos. Embora eu não considerasse essa possibilidade se não achasse que você fosse qualificado." Assim, o filme retoma as questões do cargo por influência, das relações de favor e do interesse pelo dinheiro. Alec pega a espingarda vira as costas para o protagonista e recebe a resposta esperada: "Eu odiaria decepcioná-lo", afirma Chris. A partir da chegada de Tom, a câmera muda de posição. Chris fica atrás da câmera. $\mathrm{O}$ herdeiro pega uma arma para oferecer ao ex-professor de tênis. A cena é cortada e ouve-se um tiro no campo, dado pelo protagonista. Assim como o patriarca, Chris possui uma espingarda em mãos. Se por um lado Chris deseja Nola, por outro, essa vontade é imediatamente sufocada pelo seu interesse por dinheiro.

O filme, portanto, apresenta a escolha de Chris. A resposta do protagonista de que "odiaria decepcionar" o futuro sogro deve-se aos privilégios oferecidos pelo patriarca. A aliança entre o irlandês e a elite britânica dar-se-á tanto por meio das finanças, o trabalho na empresa da família, o curso de administração, o casamento com a herdeira, como por meio do universo do crime: Chris recebe uma arma de caça dos Hewett e vai utilizá-la justamente para preservar esta aliança, o casamento com a herdeira. Na cena do porão, pode-se observar movimento semelhante à famosa formulação de Brecht do "gestus socialmente relevante" . De acordo com Brecht, "o gestus social é aquele gestus que é relevante para a sociedade, o gestus que permite que conclusões sejam tiradas a partir de circunstâncias sociais" ${ }^{\text {165 }}$. Se por um lado, a cena aparenta ser uma conversa trivial entre cavalheiros, por outro, as armas e o motivo da conversa reiteram a associação entre o mundo das finanças e o das armas, antecipando o crime. Outra vez, "a equivalência universal é conquistada pelo dinheiro, mas é sofrida pelos homens."166

Vestido com roupa semelhante à de Tom, Chris aparece na cena seguinte praticando o tiro no campo. O patriarca, seus herdeiros e outros atiradores profissionais observam a pontaria do tenista. Nola e Eleanor não acompanham a artilharia. Ao perceber a pouca habilidade do ex-professor de tênis para a prática do tiro, Tom comenta: "Não tem problema, parceiro. Isso é basicamente um aquecimento para a temporada do galo silvestre que começa

\footnotetext{
${ }^{164}$ Brecht, 1977, p.86.

165 Idem, p.104-105.

${ }^{166}$ Schwarz, 1981, op.cit., p.167.
} 
em breve. É uma diversão e tanto ${ }^{167}$." Chloe protege o namorado: "Não o assuste. A sua pontaria não é tão boa quanto no tênis, pobrezinho." O patriarca afirma que o transformará em um "talentoso atirador", característica que retoma o acordo no porão. Na cena do tiro no campo, a ausência de Nola pode ser lembrada pelo espectador no sentido de que ela avisara que o protagonista "está sendo preparado para o casamento" pela família Hewett. Chris fará um curso de administração para ocupar um “cargo compatível”, terá "acesso a privilégios” e será transformado pela família Hewett em um "poderoso atirador". Novamente, o filme estabelece a relação entre o dinheiro e a violência. Os Hewett são atiradores profissionais.

No interior da casa de campo, observa-se Chloe lendo deitada em sua cama. Ouve-se o barulho de uma tempestade, ao passo que o protagonista aproxima-se da namorada. Chris pergunta à Chloe se ela sabe onde está o seu livro de Strindberg. Assim como faz com Dostoievski, a referência ao dramaturgo sueco aproxima o protagonista da família. A predileção de Chris pelos clássicos constitui um traço de distinção. No entanto, a menção a Strindberg no filme de Allen não é aleatória. De maneira semelhante à utilização feita pelo filme de Crime e Castigo, a dramaturgia de Strindberg pode contribuir para a análise do filme. Não se trata de uma referência fortuita ao dramaturgo sueco na obra de Allen ${ }^{168}$, mas a menção a Strindberg serve como comentário às ações do protagonista. Trata-se, portanto, de uma referência calculada.

O criado Jean da peça Senhorita Júlia [1888], de Strindberg, assemelha-se ao protagonista de Match Point. Assim como Chris, Jean é também um jovem pobre e arrivista em busca da ascensão social por meio do casamento com uma moça rica, a senhorita Júlia que dá título à peça. No prefácio à Senhorita Júlia, pode-se recuperar o parentesco entre Jean e Chris. Strindberg afirma que o personagem "é o tipo que funda uma espécie, alguém em que o processo da diferenciação pode ser observado. Ele era o filho de um pobre agricultor que soube se transformar em um futuro nobre. Jean foi rápido em aprender, desenvolveu os sentidos refinados (olfato, paladar, visão) e um olhar para a beleza."169 Na peça, a jovem nobre Júlia pergunta ao empregado: "Você é um contador de estórias encantador, frequentou a

\footnotetext{
${ }^{167}$ Em inglês, a frase proferida por Tom ressalta o caráter da temporada de tiro como uma "diversão sangrenta": "But it's bloody good fun".

${ }^{168}$ A referência a Strindberg pode ser encontrada também em outros filmes do diretor como, por exemplo, Manhattan, no qual o personagem Isaac Davis [Woody Allen] afirma: “

No quesito relacionamentos amorosos com mulheres, eu sou o ganhador do prêmio August Strindberg”, o que vale como comentário para a misoginia do personagem.

${ }^{169}$ Strindberg, August. Miss Julie and other plays - trans. Michael Robinson.Oxford: Oxford World's Classics, 1998, p.61-62.
} 
escola?". Jean responde que frequentou "um pouco", embora tenha lido "vários romances e assistido a peças". O atributo indispensável para Jean, conforme o próprio personagem revela, foi ter ouvido "muita gente elegante falar. Isso foi o que mais aprendi."170 Jean imita a nobreza, adquirindo os "segredos da alta sociedade"171, característica que aproxima-o de Chris.

A temática levantada por Strindberg relaciona-se diretamente ao conflito central exposto em Match Point: a aliança de classes. O filme estabelece o contraste entre a cena no porão (na qual o patriarca oferece privilégios e uma arma ao protagonista) e a da biblioteca (momento em que a matriarca discute com Nola). Enquanto toma vinho e joga xadrez com Tom, Nola é interrogada por Alec e Eleanor. A cena retoma o tema da conversa no bar entre Nola e Chris, figurando como uma espécie de novo teste para Nola no qual ela será também eliminada.

Enquanto observa o jogo de xadrez entre Nola e Tom - no qual a norte-americana está perdendo -, o patriarca pergunta a respeito do resultado do teste de atuação. Nola revela que não conseguiu o papel. Nesse momento, a câmera acompanha o percurso de Alec que se aproxima da esposa e senta-se em um sofá, de costas para a câmera. Observa-se a reação da matriarca e do patriarca à resposta de Nola. Eleanor e Alec estão sentados em sofás semelhantes, cuja disposição forma um ângulo de $90^{\circ}$, o que confere a ideia de um espaço fechado. Nesse ponto, o espectador já pode perceber o contraste entre a distância do patriarca e da matriarca, fechados em um cerco, em relação à Nola e a proximidade entre Alec e Chris no porão.

$\mathrm{Na}$ cena da biblioteca, pode-se questionar, entre outros aspectos, o papel do cômodo ancestral no cotidiano dos Hewett. Nas diversas cenas em que o espaço aparece não há nenhum momento em que o local é utilizado propriamente para a leitura e consulta dos livros. As obras que compõem a biblioteca aparecem como ornamento, objetos de decoração e de posse assim como as pinturas a óleo, tapetes e esculturas que decoram o local. Na cena, os personagens lêem jornais e jogam. Nesse momento, a biblioteca aproxima-se mais a um salão de jogo no qual Nola é eliminada. Nesse ponto, fica claro que Alec e Eleanor são os personagens que dão as cartas do jogo.

Enquanto Nola explica sobre o teste de atuação, ouve-se um bocejo do patriarca que abre o jornal. O espectador pode ler a manchete: "Get real, says vandal victim" ("Caia na real,

\footnotetext{
${ }^{170}$ Strindberg, op.cit., p.84.

${ }^{171}$ Ibid., p.62.
} 
diz vítima de vandalismo"). Se por um lado, o gesto de Alec mostra o desinteresse do patriarca por Nola, por outro, a utilização da manchete de jornal pelo filme traz um comentário à cena ao incluir a fala de uma vítima de vandalismo e a expressão "caia na real" comenta a posição de Nola na família (o recado que será dado por Eleanor será nesse sentido). De maneira semelhante ao patriarca, Eleanor toma gim e faz palavras cruzadas no jornal. A matriarca enquadra a noiva de Tom: "E por quanto tempo você vai continuar tentando?" Nesse momento, a câmera muda de posição, ouve--se um trovão e observa-se o rosto de Nola estupefato com a violência da futura sogra. O noivo encara a mãe. Nola repete a pergunta feita pela matriarca: "Por quanto tempo?" A câmera retorna para Eleanor e Alec. A matriarca continua o seu recado: "Se o tempo passa e nada de significante acontece, por quanto tempo você vai continuar tentando até decidir tentar outra coisa?" Nesse ponto da cena, pode-se observar que o barulho da tempestade, a composição da mise-en-scène e o diálogo entre os atores "representaram o mesmo ato de maneira independente" $" 172$, a saber, o cerco fechado da família Hewett sobre Nola.

Apesar de se tratar de uma pergunta em um suposto diálogo, Eleanor retoma as palavras cruzadas no jornal. Nola para de olhar para o jogo de xadrez e observa a reação do noivo. O jovem Hewett intervém na discussão: "Eu não acho que a Nola chegou a este ponto, mãe", mas permanece olhando para o tabuleiro do jogo de xadrez. A matriarca prossegue: "Não estou dizendo isso. Estou apenas dizendo que você pode tentar ser atriz por um tempo, mas se não conseguir, tem que se perguntar: 'É isso mesmo o que eu quero para a minha vida? É isso o que quero? "”. A atriz responde à provocação da futura sogra: "Sim, eu me faço essa pergunta." Eleanor dirige-se ao filho: "Está vendo, é apenas lógico, Tom. Sobretudo para uma mulher. É um negócio muito cruel para uma mulher e à medida que você envelhece, o tempo passa e nada acontece, fica cada vez mais difícil." O patriarca intervém: "Eleanor, a Nola não está exatamente acima da idade." A matriarca ri: "Não estou dizendo 'agora'. Mas sou ótima para encarar a realidade." Nola fica em silêncio. O noivo tenta defendê-la: "A sua opinião sobre a realidade é sua e nada mais. E francamente, não é todo mundo que está interessado em ouvi-la." Alec pede para que Tom não aumente a voz com sua mãe. Aos olhos do espectador, a descortesia provém da classe dominante, representada pela família Hewett. Tom discute com o pai: "Eu não estou levantando a minha voz. Mas desculpe-me, papai, ela está sempre pegando no pé da Nola, desencorajando-a frequentemente por meio de insinuações".

\footnotetext{
${ }^{172}$ Brecht, 2000, op.cit., p.13-14.
} 
O olhar da câmera volta para Eleanor, que não interrompe o discurso: "Eu estou apenas dizendo que ser ator é tão ilusório, aqueles que têm talento logo percebem. Perseguir este objetivo só porque não quer admitir a derrota para os amigos em casa não é realista. Desculpe-me, mas é o que sinto.” Enquanto Eleanor conclui a sentença, a câmera volta para Nola que verte mais um gole de vinho, permanecendo em silêncio. Ao término do recado da matriarca, a jovem norte-americana pede licença e retira-se da biblioteca. A câmera não acompanha Nola, permanece no local, mostrando a reação dos Hewett à saída da norteamericana. A matriarca permanece sentada no sofá, o filho reclama com a mãe: "Você sabe que esse é o calcanhar de Aquiles [da Nola]" e o pai pede para que Eleanor pare de tomar gim tônica.

Para caracterizar a cena, Allen usa o campo/contra-campo. A técnica neste caso é utilizada para contrapor os pares, Alec e Eleanor em oposição a Tom e Nola. A cena tematiza também a submissão do herdeiro aos pais e mostra o domínio dos Hewett sobre todos os aspectos. Neste jogo - travado no campo do inimigo no qual o patriarca e a matriarca dão as cartas -, Nola está em desvantagem em comparação a Chris. Ela não consegue associar-se aos pais de Tom tal como faz o protagonista. Ao contrário do tratamento para com o irlandês, o patriarca não oferece "privilégios" para Nola. A carreira escolhida pela atriz é avaliada pelos futuros sogros como um "negócio arriscado". Destaca-se também que Nola como mulher é eliminada por sua semelhante, a matriarca. No filme, o conflito masculino/feminino relacionase à significação econômica. A matriarca adota um critério de classe para avaliar a carreira de Nola como um "negócio cruel, sobretudo para uma mulher". A informação de que a Hewett Inco. é uma empresa inserida no mercado financeiro permite que Eleanor "seja ótima" para calcular os riscos de um eventual casamento entre seu filho e Nola. A matriarca sugere a falta de talento da atriz norte-americana e aponta para as poucas chances de sucesso da noiva de Tom. Novamente, destaca-se a diferença entre Chris e Nola, o primeiro, além de ser homem, possui as habilidades e destrezas do empreendedor. Após o contratempo com a matriarca, a jovem norte-americana retira-se do local que é comandado por Eleanor e Alec.

Assim como Jean e Kristin em Senhorita Júlia pertencem à mesma classe, Chris e Nola fazem parte de um mesmo mundo. Outro indício de que a referência a Strindberg é calculada se dá no papel das mulheres na configuração social: a personagem Kristin figura como se fosse uma "escrava feminina" 173 e a própria senhorita Júlia foi considerada por

${ }^{173}$ Strindberg, op.cit., p.63. 
Strindberg como inferior a Jean: “Apesar de ser um arrivista, Jean é superior a senhorita Júlia por ser homem. Sexualmente, ele é o aristocrata, por conta de sua virilidade, seus sentidos mais refinados e sua habilidade em tomar a iniciativa" ${ }^{\text {174 }}$. Na fala de Eleanor o recado é explícito: “especialmente por ser mulher”, Nola está em posição de desvantagem. O temperamento da atriz norte-americana foi preterido pela família Hewett, afeita à elegância, aos atributos do jovem empreendedor irlandês.

Na composição da cena, a propriedade fala mais alto: Nola não possui as mesmas habilidades e destrezas que o protagonista e por isso não "está sendo preparada para o casamento" pela família Hewett. O barulho da chuva que acompanha a cena na biblioteca reafirma tensão e o cerceamento da família inglesa com Nola, o que contrasta com o acordo entre cavalheiros estabelecido no porão no qual o protagonista tem acesso às armas da família.

Após a saída de Nola, o espectador volta a acompanhar o percurso de Chris que permanece a procura do livro de Strindberg. Por meio de uma vidraça, acompanhamos a norte-americana caminhando pelos jardins da propriedade sob forte tempestade. Chris aproxima-se da janela e observa Nola. O protagonista sai do interior da casa de campo para encontrá-la. O foco narrativo afasta-se do protagonista e retorna para Chloe que permanece em seu quarto lendo. A câmera mostra Chris e Nola no campo de trigo, o protagonista afirma que desejava encontrá-la.

\author{
[Nola Rice]: "Eu estou chateada, só quero ficar sozinha." \\ [Chris Wilton]: "Não pretendo me intrometer." \\ [Nola Rice]: "Preciso de uma bebida." \\ [Chris Wilton]: "Eu gosto quando você bebe, fica mais solta." \\ [Nola Rice]: "Fico?" \\ [Chris Wilton]: "Sim. Confiante." \\ [Nola Rice]: "Não acho que isso seja uma boa ideia. Não devia ter \\ me seguido até aqui." \\ [Chris Wilton]: "Você se sente culpada?" \\ [Nola Rice]: "E você? Não podemos fazer isso." \\ [Chris Wilton]: "Eu sei." \\ [Nola Rice]: "Isso não levará a lugar nenhum."
}

No campo de trigo, pode-se encontrar novamente a indicação do olhar escopofílico. Segundo Laura Mulvey, neste modo de olhar verifica-se a aproximação entre o protagonista e o espectador: "Ambos estão associados com um olhar: o do espectador, em contato

\footnotetext{
${ }^{174}$ Ibid., p.62.
} 
escopofílico direto com a forma feminina exposta para a sua apreciação (e conotando a fantasia masculina), e o do espectador fascinado com a imagem do seu semelhante colocado num espaço natural, ilusório, personagem através de quem ele ganha o controle e a posse da mulher na diegese. Esta tensão e o deslocamento de um polo a outro podem estruturar um único texto." ${ }^{175}$ Se por um lado a cena do encontro entre os dois amantes no campo de trigo marca um ato de resistência dos estrangeiros frente à opressão na casa de campo da família Hewett, por outro, a união entre Chris e Nola remete às relações destrutivas, por meio da referência a Strindberg, nas quais “[...] a dança da excitação sexual é, mais uma vez, a dança da morte" ${ }^{176}$. Diferentemente de Nola, Chris é um aliado dos Hewett. Em Match Point, a idealização do campo inglês ${ }^{177}$, no qual a paisagem bucólica traria um sentido de plenitude e de comunidade é imediatamente afastada: trata-se de luta, de um lugar de competição que, assim como o Swiss Re na cidade, é regido pelas regras do capital.

Do campo de trigo, o filme passa para o curso de administração na cidade. Observa-se o comentário irônico de Allen, Chris não precisa de um diploma universitário para ocupar um cargo melhor na empresa, apenas um rápido curso sobre o mercado financeiro é suficiente. Se no campo de trigo vimos a paixão do protagonista por Nola, a cena seguinte retrata o seu extremo oposto, a falta de interesse do ex-professor de tênis durante o curso de administração (indicado pelo patriarca na casa de campo). Em contraposição ao furor na cena do campo de trigo, o filme mostra também o tédio do protagonista ao lado de Chloe e sua família durante a apresentação de Rigoleto, no Royal Opera House. Observa-se em um primeiro momento, a cantora de ópera no palco:

[Gilda]: "Gualtier Maldè!... nome di lui sì amato, / Scolpisciti nel core innamorato! / Caro nome che il mio cor [...]"

A ária "Caro nome che il mio cor" representa o momento em que Gilda canta o suposto nome de seu amado, o duque de Mântua ${ }^{178}$. Em nome do amor pelo duque, Gilda

\footnotetext{
175 Mulvey, op.cit., p.446.

${ }^{176}$ Strindberg, op.cit., p.150.

${ }^{177}$ Conforme argumenta Raymond Williams: “A experiência inglesa é especialmente significativa, na medida em que uma das transformações decisivas nas relações entre campo e cidade ocorreu na Inglaterra muito cedo, e num grau tão acentuado que, sob certos aspectos, não encontra paralelo. A Revolução Industrial não transformou só a cidade e o campo: ela baseou-se num capitalismo agrário altamente desenvolvido, tendo ocorrido muito cedo o desaparecimento do campesinato tradicional." Ver Williams, Raymond. [O campo e a cidade], op.cit., p.12.

${ }^{178}$ A ópera Rigoleto [1851], de Giuseppe Verdi, baseia-se na peça de Victor Hugo, Le Roi s'Amuse. O personagem de Rigoleto, o concurda, é vivamente caracterizado na música [...]. Mas a ópera oferece ainda outros
} 
acaba se sacrificando. Nesse sentido, a ópera pode relacionar-se a Nola que assim como Gilda será eliminada.

No plano da imagem, vê-se o camarote da família Hewett. O espectador observa os três casais (Alec e Eleanor, Chris e Chloe, Tom e Nola). Durante a apresentação, Tom atende o celular, mas a ligação é para Nola. No camarote do Royal Opera House vê-se que o jovem Hewett tem influência também sobre as chances profissionais da atriz. Vale lembrar também que a nova chance profissional para Nola é concedida visando reparar a grosseria cometida por Eleanor na biblioteca da casa de campo. Ao perceber a saída da noiva de Tom, Chris retira-se do camarote para encontrar Nola no corredor do teatro. A noiva de Tom explica ao tenista que não pretende dar prosseguimento ao romance iniciado no campo de trigo:

[Nola Rice]: "O que aconteceu, aconteceu, Chris. Tudo fugiu ao controle por vários motivos, eu estava chateada, tinha bebido, a tempestade estava forte..."

[Chris Wilton]: "Pare de racionalizar."

[Nola Rice]: "Não estou racionalizando. Paixões são paixões, mas nós estamos envolvidos com outras pessoas."

[Chris Wilton]: "Você não é uma atriz tão boa. Não é possível."

[Nola Rice]: "Você sonhava em fazer amor comigo. Não digo que a fantasia não passou pela minha cabeça também, mas tivemos o nosso momento. Temos que retomar as nossas vidas, voltar à realidade. Chris, nós vamos ser concunhados." fazendo amor."

[Chris Wilton]: "Você é exatamente como imaginei que você seria

[Nola Rice]: "Chris, esqueça isso. Acabou."

No diálogo entre Nola e Chris vemos que a chance de aliança intraclasse, que poderia ser sugerida na cena do campo de trigo, é excluída do horizonte de possibilidades também por Nola. Evidencia-se que, a despeito da opressão sofrida na biblioteca, Nola quer "voltar à realidade", extinguindo o romance com Chris e aliando-se aos Hewett.

papéis notáveis. O duque de Mântua foi o papel em que Caruso estreou na Metropolitan Opera House novaiorquina, a 23 de novembro de 1903. Como se sabe, o enredo de Rigoleto "gira em torno das escapadas amorosas do duque de Mântua, com a cumplicidade de Rigoleto, seu bufão, que por seu espírito caústico e sua falta de escrúpulos granjeou não poucos inimigos na corte, o que acabou rendendo-lhe a maldição de Monterone. Rigoleto tem uma filha, Gilda, que mantém em estrita reclusão. Mas o duque, sem saber de quem se trata, viu-a e apaixonou-se por ela. Por conta do interesse do duque por sua filha, Rigoleto planeja assassiná-lo. No entanto, o duque acaba seduzindo a irmã do malfeitor contratado por Rigoleto e o duque sai ileso. Decidida a salvar o duque da armadilha encomendada por seu pai, Gilda é apunhalada ao entrar, no lugar do duque. Rigoleto recebe o corpo envolto em um saco, ele está a ponto de atirá-lo à água, quando ouve o duque cantar. Abrindo o saco, dá com sua filha moribunda, ela ainda consegue exalar: "Amei-o demais - agora morro por ele"”. Ver Kobbé, op.cit., p.316-321. 
Na cena seguinte, observa-se o cotidiano do protagonista como novato executivo. Em primeiro plano, Allen apresenta o privilégio conquistado pelo protagonista: o carro de luxo com motorista, conforme fora prometido pelo futuro sogro na casa de campo - conquanto o tenista fizesse o curso de administração. Chris sai com uma sacola de compras da loja de joias Cartier, outra marca de luxo em que ele procura investir. Assim como o curso de administração, os livros, o vinho, as roupas e as joias compradas pelo protagonista serão entendidas neste trabalho como investimentos, nos termos apresentados por López-Ruiz: "Um curso de degustação de vinho é um consumo ou é um investimento? Conquanto melhore as capacidades do indivíduo como consumidor, aumente o seu capital humano (seu capital de consumo), pode-se dizer que se trata fundamentalmente de um investimento. De fato, pode trazer grandes benefícios não apenas ao aumentar as satisfações futuras a obter através do consumo, mas ao aparelhá-lo com uma ferramenta de socialização necessária para aceder algum dia, por exemplo, aos níveis mais altos do mundo corporativo. Em outras palavras, o investimento feito no curso de degustação não apenas vai trazer futuras satisfações ao permitir um consumo de vinhos mais sofisticados - incrementando, assim, seu capital de consumo -, mas acaba sendo também parte do capital de produção porque vai permitir um uso mais eficiente do seu networking (da sua rede de relacionamentos) e aumentar as probabilidades de sucesso no próprio marketing pessoal, atividade fundamental e tarefa imprescindível para um capitalista do seu capital humano." 179

$\mathrm{O}$ acaso novamente é incorporado pelo filme como material: o ex-professor de tênis encontra o amigo Henry na New Bond Street ${ }^{180}$, local que une, como consumidores de alto luxo, investidores, tanto o executivo da transnacional como o tenista do circuito internacional de tênis. O personagem Henry funciona no filme como uma espécie de "consciência" para Chris, ele é aquilo que Chris ainda seria se não tivesse atravessado o rio, indo para Londres. $\mathrm{Na}$ cena do primeiro encontro entre o protagonista e Henry, observa-se em primeiro plano, o motorista e o novo carro de Chris - suas novas conquistas. À medida que os dois amigos conversam, a câmera mostra outras fachadas de lojas de luxo que compõem a New Bond Street. Henry admira-se com a marca do carro do amigo: "Olha só para você. Você parece estar muito bem." O protagonista avisa ao amigo que o carro pertence à empresa: "Sou uma

\footnotetext{
${ }^{179}$ Ver López-Ruiz, op.cit., p.225.

180 “A New Bond Street é o lugar de lojas exclusivas em Londres, incluindo lojas de estilistas famosos, joalherias

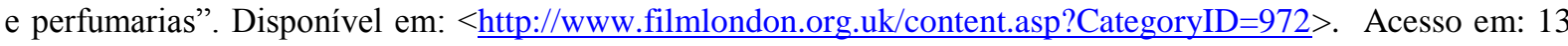
jan. 2010.
} 
engrenagem em um escritório, acredita?" Chris explica ao amigo as relações de favor: "É quem você conhece, Henry. Eu me envolvi com uma mulher muito legal, a família dela tem muito dinheiro: uma grande propriedade, criados, cavalos de polo. Tudo perfeito.”

O encontro com o amigo dos tempos de tenista expõe aos olhos do espectador informações sobre o protagonista. Henry revela que Chris achava o trabalho como tenista profissional "um pouco maçante". Chris confirma a informação apresentada pelo amigo: "Eu não aguentava mais". Ao contrário do protagonista, Henry afirma que continua "viajando pelo mundo, iludindo-me." Apesar de gostar do trabalho como tenista profissional, Henry compreende a opção de Chris: "É doloroso ficar chateado toda hora por ser derrotado pelos grandes tenistas.” A indicação, feita por Henry, de que o protagonista não seria um tenista tão promissor faz com que Chris, para relatar sua trajetória de vida, retome a referência à sorte, apresentada no prólogo do filme: "Não é incrível ver como a sua vida pode mudar, se a bola bate na rede e cai do outro lado ou volta para você?" O amigo comenta a técnica do extenista: "Mas eu sempre admirei o seu jeito de jogar. Você é muito firme, frio sob pressão, mas criativo. Poderia ser um poeta com uma raquete como Laver foi. Quando eu jogava com você, você nunca se abalava. Estou lhe dizendo, mais algumas bolinhas caindo para o seu lado e você poderia ter derrotado alguns dos grandes tenistas." O executivo combina um almoço com o amigo e informa que está de mudança para um novo apartamento. Chris revela que poderá pagar o almoço com as despesas da empresa - outro privilégio entre os benefícios oferecidos pelo patriarca.

A cena seguinte mostra a soirée na casa londrina dos Hewett. Chloe e o pai conversam, ao passo que observamos os convidados da festa. O protagonista pergunta à namorada se ela sabe tocar piano, atributo essencial das ladies inglesas. No entanto, Chloe, que já havia afirmado ser "atrapalhada" no tênis, considera-se "terrível tocando piano", o que indica que a predileção para música clássica deixou de ser essencial ao cultivo das jovens inglesas ricas.

Em oposição à maneira ríspida com que tratara Nola na biblioteca da casa de campo, Eleanor segura um copo de vinho em uma das mãos e apoia com a outra no futuro genro: "Então, quando vocês dois vão se casar? Não faça essa cara de surpresa, vocês dois não se desgrudam há muito tempo. Não me digam que o assunto não passou pela cabeça de vocês." Chloe retira a mãe da conversa, enquanto o patriarca acerta os detalhes do casamento: “Eleanor não se segura quando bebe um pouco." Diferentemente de Nola, Chris não perde a 
oportunidade para agradar os sogros: "Olha, é uma pergunta sensata, Chloe e eu já discutimos isso." O patriarca conduz o futuro genro: "Eleanor e eu ficaríamos felizes em tê-lo na família e Tom adoraria tê-lo como cunhado. Tudo o que precisarem podem contar conosco." Chris agradece a confiança do futuro sogro. O diálogo sela o acordo entre Alec e Chris enquanto os dois seguram copos de vinho e caminham pela casa da cidade durante a soirée. No campo e na cidade o movimento é o mesmo: trata-se da aliança de Chris com a família Hewett.

No momento seguinte, Chris verte um gole de vinho ao passo em que desce as escadarias da casa londrina dos Hewett. A cena relaciona-se à da tempestade na casa de campo. Chris observa Nola por intermédio de uma vidraça, como se ela estivesse exposta em uma vitrine "para ser olhada". Contudo, desta vez, a atriz não está sozinha, mas em companhia do noivo. O protagonista surpreende o casal, o jovem Hewett provoca o futuro cunhado: "Vocês dois se conhecem, não? Tenho certeza de que se conhecem." O tenista tenta esquivar-se: "Desculpem-me, eu não imaginava." Tom estimula o desejo do cunhado: "Por que nos escondemos na dispensa? Foi tudo culpa dela. O que posso fazer se ela fica excitada em lugares onde podemos ser pegos?"

Novamente, Nola é apresentada como objeto do desejo e de disputa entre Chris e Tom. O jovem Hewett desafia o protagonista: "Todos os homens que a vêem, querem atacá-la. Não é verdade, Christopher?" Chris percebe que perdeu Nola para o irmão de Chloe. Ele chega a esmorecer ao observar que a paixão de Nola por Tom possa ser semelhante ao que ela demonstrara por Chris no campo de trigo. Tom percebe que o futuro cunhado quase desmaiou, mas o protagonista disfarça: "Estou bem. Eu não deveria beber de estômago vazio." Nesta cena, Allen retoma o tema do olhar escopofílico no cinema narrativo ${ }^{182}$. A indicação de que Nola fica excitada em lugares públicos retoma a ideia de que ela figura como "um objeto de estímulo sexual através do olhar" ${ }^{183}$. Por trás de uma janela, Nola aparece retirando a calcinha. A beleza de Nola é para "exibição", observada aqui em seu aspecto financeiro, venal. Nesse ponto, retomaremos a formulação de Schwarz no momento

\footnotetext{
${ }^{181}$ Há referência à paródia de filmes italianos feita em Tudo o que você queria saber sobre sexo, mas tinha medo de perguntar [1972], na qual o personagem interpretado por Woody Allen mantém relações sexuais com a esposa em lugares públicos, pois ela sente prazer apenas em locais onde o casal pode ser surpreendido.

${ }^{182}$ Pode-se observar novamente a coincidência entre o desejo do protagonista e o desejo do espectador. Há uma cumplicidade do espectador com o universo representado por Chris o que em certo sentido mostra um ponto em comum entre Allen e Hitchcock. Para Laura Mulvey, nos filmes de Hitchcock, o herói fica "fascinado com uma imagem através de um erotismo escopofílico, enquanto assunto do filme. Além disso, nestes casos, o herói exibe as contradições e tensões experimentadas pelo espectador. [...] O olhar é central ao enredo, oscilando entre voyeurismo e fascinação fetichista". Ver Mulvey, op.cit., p.449.

${ }^{183}$ Mulvey, op.cit., p.443.
} 
em que relaciona a beleza ao dinheiro no romance $O$ pai Goriot: "A beleza [...] é feminina e apela para o senso masculino de propriedade. Exibe-se aos presentes, mas destina-se a um só. Como a mercadoria, que põe gula no olhar de todos mas responde somente à maior oferta, ela alimenta o seu brilho no desejo à volta." 184

\subsection{Dois casamentos}

“A individualização crescente dentro da sociedade torna o dinheiro cada vez mais inadequado como mediador das relações puramente individuais".

Georg Simmel, A filosofia do dinheiro.

Se retratasse apenas a ascensão social do protagonista, o desfecho do filme poderia realizar-se na cena do casamento de Chris, o que confirmaria a utilização do cinema clássico. De acordo com David Bordwell, "O filme hollywoodiano clássico apresenta indivíduos psicologicamente definidos que lutam para solucionar um problema decisivo ou para atingir objetivos específicos. Durante o desenvolvimento da narrativa, os personagens entram em conflito uns com os outros ou com circunstâncias externas. A história termina com a vitória decisiva ou derrota, a resolução do problema e uma evidente conquista dos objetivos" 185 . Assim conquistado o propósito do protagonista, o decisivo match do título, o filme chegaria ao fim.

No entanto, conforme procuraremos demonstrar, a cena do casamento representa uma espécie de anticlímax, no qual não há espaço para qualquer romantização. Da conversa entre Alec e Chris que acertam o casamento, ao flagrante com Nola e Tom na dispensa da residência londrina dos Hewett, Allen corta para a cerimônia na igreja de São Marcos localizada na casa de campo. O filme relaciona os três eventos, mostrando que o desejo de Chris permanece com Nola, no entanto, o interesse financeiro por Chloe fala mais alto. O corte seco da casa londrina para a casa de campo contrasta com a leveza suscitada pela música extra-diegética, a ária "Mia Piccirela" (que já havia caracterizado o encontro entre Chris e Chloe na cena em que o casal passeia por Londres).

\footnotetext{
${ }^{184}$ Schwarz, op.cit., p.175.

${ }^{185}$ Bordwell, op.cit., p.157.
} 
A contraposição entre a atmosfera sentimental trazida pela música, o acordo entre Chris e o patriarca, o desejo do protagonista pela norte-americana e a cerimônia de casamento do protagonista com a herdeira indicam que o casamento relaciona-se ao acordo financeiro e não ao amor pela "piccirela". Nesse ponto, retomaremos a ideia do casamento por dinheiro, nos termos apresentados por Simmel: "Sempre que um relacionamento baseado em interesses financeiros existe, nos quais a superioridade e a vantagem repousam desde o começo para um dos lados, estas tendências podem crescer ainda mais, radical e profundamente nesta direção, como se os outros motivos de natureza objetiva e material fossem a base para essa relação"

Na igreja, situada no Englefield Estate, em que foram celebradas durante séculos as uniões da família, mantendo a propriedade em suas mãos, Chris e Chloe aparecem de costas para a câmera. A aliança é sacramentada pelo padre: "Eu os declaro marido e mulher. Pode beijar a noiva". O jovem arrivista retira o véu e beija Chloe, os noivos olham para os convidados, ouvem-se os aplausos dos presentes ${ }^{187}$ (que não são vistos pelos espectadores) e a cerimônia termina. Dessa maneira, a cerimônia de casamento é apenas formal: trata-se de uma troca de alianças acertada anteriormente. Allen dá preferência aos "outros motivos de natureza objetiva e material" relacionados à cerimônia de casamento, tais como o emprego no Swiss $R e$, o acordo no porão na casa de campo, o acesso às armas, a prática do tiro, o carro, o motorista, as roupas, os outros benefícios recebidos pelo protagonista e a conversa entre Chris e o patriarca na casa da cidade.

Ao contrapor a cidade e o campo, relacionando-os a todo o momento por meio dos personagens, verifica-se um aproveitamento, no filme de Allen ${ }^{188}$, de diversas questões trabalhadas pela literatura inglesa. Há um comentário irônico a respeito da Englishness. Neste

\footnotetext{
${ }^{186}$ Simmel, op.cit., p.382.

${ }^{187}$ No filme, conforme já argumentamos, existem poucas referências à família do jovem irlandês que não é mencionada durante o casamento. Em Match Point, a figura da mãe do protagonista é eliminada. Na adaptação que faria de Uma tragédia americana, Eisenstein pretendia "rasgar algumas das máscaras - apesar de não todas - da figura monumental da mãe". Segundo o cineasta, o próprio Dreiser "foi o primeiro a elogiar tudo o que foi acrescentado a sua obra por nosso tratamento". Ver Eisenstein, Sergei. A forma do filme / Sergei Eisenstein; apresentação, notas e revisão técnica, José Carlos Avelar; trad. Teresa Ottoni. Rio de Janeiro: Jorge Zahar , 2002, p.103.

${ }^{188}$ Em Match Point, mas não somente, o diretor norte-americano realiza uma espécie de comentário irônico em relação à Englishness. Nos filmes subsequentes à Match Point (2005), o tema é retomado. Em Scoop (2006), o diretor utiliza o mesmo Englefield Estate para revelar que o filho de um famoso lorde inglês é, na verdade, um serial killer. A cena da tentativa de assassinato - com um barco no lago - retoma o romance de Dreiser. Diferentemente de Roberta Alden (a namorada pobre de Clyde), a protagonista do filme de Allen sabe nadar e se salva. O nome da personagem no filme de Allen, Sondra Pransky, faz referência a Sondra Finchley, personagem homônima do romance de Dreiser. Em $O$ sonho de Cassandra (2007), dois irmãos, membros da classe trabalhadora inglesa em busca da ascensão social, realizam um crime para o tio endinheirado. Após o crime, Ian e Terry acabam rivalizando entre si.
} 
trabalho procuraremos entender a especificidade da cultura britânica nos termos expostos por Raymond Williams: "Uma literatura, a inglesa, que é talvez mais rica do que qualquer outra em termos da gama de temas referentes ao campo e à cidade; e uma sociedade que atravessou um processo de desenvolvimento histórico - primeiro numa economia e numa comunidade rural, depois num contexto urbano - muito cedo e de modo muito completo; em última análise, é apenas uma história específica, mas ela tornou-se, sob alguns aspectos importantes, um modo de desenvolvimento dominante em muitas partes do mundo" ${ }^{\text {"189 }}$.

De acordo com Williams, só podemos ver a cidade como representação do capitalismo, "desde que se possa afirmar também que este modo de produção teve origem especificamente na economia rural da Inglaterra e lá produziu muitos dos efeitos característicos - aumento de produção; reorganização física de um mundo totalmente disponível; deslocamento de comunidades tradicionais; a formação de um resíduo humano que veio a se transformar numa força, o proletariado - que foram posteriormente encontrados, em diversas formas, em cidades e colônias e em todo um sistema internacional"190.

Em Match Point, há também um resgate das questões trabalhadas por Jane Austen. Allen usa da "observação fria e controlada"191 característica de Austen para comentá-la. De acordo com Raymond Williams, a autora retratou "uma sociedade abertamente voltada para a aquisição, e também preocupada com a transmissão da riqueza." ${ }^{192}$ Nos romances de Austen "boa parte do interesse, das fontes de ação, encontra-se nos reveses da sorte - fatos ligados a um processo geral de mudança e a uma certa mobilidade social - que estavam afetando as famílias de proprietários rurais da época." ${ }^{193}$ De acordo com Terry Eagleton: "O aumento da mobilidade social representava uma ameaça à tranquilidade do campo, que Austen estimava tanto. A riqueza urbana, a ambição social insone, a frivolidade moral e os costumes metropolitanos estavam se infiltrando no campo. Eles faziam isso, não apenas por meio do mercado do casamento, assim como o capital do campo [landed capital] procurava um modo de vida novo ao assimilar, através do casamento, os filhos dos capitalistas da cidade e os dos financistas" $" 194$.

\footnotetext{
${ }^{189}$ Williams, 1989, op.cit., p.390-391.

${ }^{190}$ Ibid., p.391.

${ }^{191}$ Ibid., p. 162.

192 Ibid., p.161.

${ }^{193}$ Ibid., p.159.

${ }^{194}$ Eagleton, Terry. The English Novel: an introduction. Oxford: Blackwell Publishing, 2005, p.116.
} 
No filme de Allen, a referência ao universo de Jane Austen faz-se por meio da família Hewett, como uma espécie de reminiscência da "landed gentry", nos termos apresentados por Eagleton: "Jane Austen não escrevia sobre a família a despeito da sociedade; pelo contrário, nos tempos de Jane Austen, a família era a sociedade, ou ao menos, o setor que a governava. No século XVIII, poucas centenas de famílias possuíam um quarto das terras cultivadas da Inglaterra" ${ }^{\prime 195}$. Nesse sentido, durante o filme, Allen mostra que, na Inglaterra, a propriedade continua sob o domínio de uma minoria. Conforme argumenta Terry Eagleton, a "gentry não era apenas um grupo de empreendedores, mas o ápice de todo um modo de vida do campo, que foi pensado para incorporar os mais elevados valores da sociedade inglesa. Cultura no sentido do cultivo da terra - agricultura - gerou rendas, que por sua vez deram origem à cultura, no sentido da elegância dos costumes e da nobreza de espírito. De certa forma, então, esses aristocratas do campo [landed aristocrats] e os senhores do campo [country gentlemen] continuaram a cultivar um estilo de vida tradicional do campo, mesmo que esta auto-imagem cultural estivesse cada vez mais em contradição com a sua base econômica. É este tipo de ordem do campo que Austen admirava e apoiava"196.

Diferentemente de Austen que acredita na "necessidade de uma reforma e no melhoramento do status quo"197, Allen ironiza a ordem do campo ao retomar o "passado" simbolizado pela casa de campo e incorporá-lo em um filme sobre o movimento global do capitalismo contemporâneo. Nesse sentido, o cineasta norte-americano tece um comentário sobre a direção regressiva da vida atual. Ele apresenta a outra face dos valores tradicionais do campo, a saber, a cultura como investimento e como fachada para a exploração. Conforme argumenta Eagleton, a cultura na Inglaterra tem papel determinante, pois foi nela, "no sentido mais amplo dos valores, normas, ideais e qualidade de vida elevada, que as classes de proprietários do campo confiavam sua autoridade. O objetivo deles foi conseguir a hegemonia - ganhar a lealdade e a aprovação de seus subordinados por meio do exemplo moral - mais do que simplesmente governá-los pela força. E as famílias de proprietários ingleses obtiveram em geral sucesso notável neste projeto" ${ }^{\prime 198}$.

No filme de Allen, logo após o casamento, observa-se a transmissão dos bens da família Hewett. O presente dos pais de Chloe para o jovem casal não são mais as propriedades

\footnotetext{
${ }^{195}$ Eagleton, op.cit., p.115.

${ }^{196}$ Ibid,.116.

${ }^{197}$ Ibid, p.121-122.

${ }^{198}$ Ibid, p.117-118.
} 
rurais, mas sim o imponente apartamento no Parliament View ${ }^{199}$, edifício que guarda semelhanças com o revestimento espelhado do Swiss Re. A música extra-diegética que caracterizara a cerimônia na igreja de São Marcos continua no apartamento da cidade. Todavia, a paixão pela "piccirela" sugerida pela ópera é substituída, no filme, pela transmissão hereditária dos bens. Após o casamento, Chloe quer ter filhos, o investimento é rapidamente capitalizado:

[Chris Wilton]: "Gostaria de ter dinheiro para pagar por esse apartamento."

[Chloe Hewett]: "Não comece com isso de novo. Você sabe que papai fica feliz em ajudar. Veja a claridade entrando aqui todo o dia."

[Chris Wilton]: "É lindo. Mas, é enorme, vou me perder aqui dentro. Já te disse que tenho medo de altura?" engravide."

[Chloe Hewett]: "Sério? Isso pode ser um problema. Quero que me

[Chris Wilton]: "Chloe, nós já discutimos isso. É muito cedo."

[Chloe Hewett]: "Não é cedo, dormimos juntos há anos. Quero três filhos e quero tê-los enquanto sou jovem. Vamos lá, você pode fazer isso, você tem um saque poderoso."

Os dotes físicos do protagonista, ressaltados pela esposa, reaparecem na cena seguinte no Queen's Tennis Club. O protagonista que começou como empregado do clube de tênis retorna como sócio do estabelecimento. Tom erra as jogadas e é repreendido pelo exprofessor de tênis: "Ei, onde você está?" O jovem Hewett explica ao cunhado que terminou o relacionamento com Nola. A utilização da quadra de tênis nesta cena revela a eliminação de Nola pelo noivo e a continuação da vitória do protagonista no jogo entre o irlandês e a norteamericana.

Separados pela rede de tênis, Tom e Chris conversam. O protagonista, que deseja a noiva do cunhado, fica desconcertado com o término do romance: "Achei que vocês iam se casar". O jovem herdeiro assume a influência da matriarca no rompimento: "É constrangedor dizer isso, mas eu acho que a minha mãe conseguiu envenenar a relação. Não que eu tenha qualquer intenção de casar com a maldita Olívia Allred, sua principal candidata. Meu Deus, não.”

\footnotetext{
${ }^{199}$ Espelhado, o apartamento de 5 milhões de libras possui uma das melhores vistas do skyline londrino: observase o Parlamento inglês e o rio Tâmisa. Em uma das resenhas sobre o filme, o aspecto ostentador do apartamento é ressaltado: "Você conseguiria mais poder do que o apartamento de perfil ondulante com vista para o extremo sul da ponte Lambeth, onde o pai amável (e rico), Alec Hewett, instala sua filha Chloe e seu genro Chris?". Disponível em: <http://www.movie-locations.com/movies/m/matchpoint_02.html〉. Acesso em: 6 jun.2009.
} 
Todavia, Tom acaba realizando o casamento apropriado: “A verdade é que eu conheci outra pessoa, me apaixonei e percebi isso imediatamente. Embora minha mãe esteja nas nuvens com a minha decisão, eu tento pensar que isso não importa, mas você sabe o que quero dizer.” Na fala do filho, podemos observar a conquista da matriarca que é incorporada por Tom. Eleanor seria uma espécie de porta-voz da landed gentry. Assim como Jane Austen, ela "orienta suas heroínas firmemente em direção a casamentos apropriados" ${ }^{200}$. Como diz Eagleton, os valores morais eram vitais para a continuação da autoridade das classes altas inglesas: "A moral e os costumes faziam parte das questões políticas [high politics]. E tendo em vista que elas eram principalmente uma preocupação das mulheres, sendo estereotipicamente suposto que elas fossem especialistas no assunto, isso significava que as chamadas questões femininas [women's issues] estiveram no centro da esfera pública, mesmo que fossem reconhecidas raramente como tal"201.

No filme de Allen, o patriarca estabelece o acordo com Chris e a matriarca apresenta "as chamadas questões femininas" para Nola. A questão do casamento por dinheiro é colocada em evidência, por meio dos dois casamentos que são acertados pelo patriarca (o acordo com Chris no porão) e pela matriarca (o afastamento de Nola na biblioteca). Por intermédio de três cortes rápidos, Allen mostra que no casamento entre Chris e Chloe não há "união entre o subjetivo e o objetivo", pois a vontade subjetiva do protagonista é subsumida após o casamento. $\mathrm{O}$ filme estabelece o contraste entre o desinteresse de Chris por Chloe e o desejo do protagonista por Nola. Allen apresenta o ofício tedioso do protagonista no Swiss Re. Ele sai do ambiente claustrofóbico no trabalho para procurar pela norte-americana.

Assim como o edifício de negócios, o ambiente de sua residência no Parliament View Apartments é de aprisionamento. Na cena em que Chris e Chloe estão deitados na cama, a herdeira pergunta ao marido: "No que você está pensando?" O protagonista afirma que pensa "apenas nos negócios". Chloe retoma o assunto do herdeiro: "Você sabe que já faz uma semana que fizemos amor." Chris culpa os negócios: "Estou muito cansado". Recém-casada, a herdeira pergunta se está "sendo rejeitada". O marido nega. Por sua vez, Chloe insiste na concepção da criança: "Não sei o que há de errado, todas as minhas primas ficam grávidas tão facilmente." Chris tenta justificar o seu desinteresse pela esposa: “Olha, isso vai acontecer. É que estou muito cansado. Um beijo. Sonhe com os anjos.” A respeito da dificuldade para a concepção do filho entre as camadas ricas, Simmel argumenta que "não importa o quanto o

\footnotetext{
${ }^{200}$ Williams, op.cit., p.162.

${ }^{201}$ Eagleton, op.cit., p.119.
} 
amor pode ser enganoso - especialmente nos estratos superiores, cujas circunstâncias complicadas frequentemente retardam o crescimento do mais puro instinto - e não importa o quanto as outras condições podem afetar o resultado final, permanece verdade que, em relação à procriação, o amor é decididamente superior ao dinheiro como um fator de seleção" ${ }^{202}$, o que ressalta a ideia de que a união entre Chloe e Chris deve ser entendida nos termos do casamento por dinheiro.

O segundo casamento da família Hewett é filmado de maneira análoga ao primeiro. De costas para o público, o espectador não sabe quem são os noivos, o que retoma a ideia da repetição, do rito tradicional, situado na igreja de São Marcos. O mesmo pároco sacramenta os votos de maneira idêntica a que fizera no casamento de Chloe e Chris: "Eu os declaro marido e mulher. Pode beijar a noiva." A câmera distancia-se dos noivos, Tom retira o véu da noiva e beija-a. A noiva de Tom é apresentada ao espectador. Em comparação ao casamento de Chloe e Chris, neste não há introdução de música. Todos esses elementos justapostos indicam que não há singularidade na cerimônia, o que oferece, aos olhos do espectador, a ideia da repetição de um processo dentro de uma mesma família, a ideia da preservação da propriedade nas mãos de uma minoria. Outra vez, ouvem-se os aplausos dos convidados (sem que possamos vê-los). Em contraposição ao casamento de Chloe e Chris, a noiva de Tom sussurra ao jovem Hewett: "Bem na hora, já ia começar a aparecer”, revelando que ela está grávida do herdeiro.

\subsection{A intervenção corporativa nas artes}

\footnotetext{
“Ao tomar o controle de museus de arte, as corporações alteraram significativamente as formas como essas instituições funcionam, e também a percepção que temos delas e da arte abrigada sob seus tetos. Ao fechar obras de arte no interior de seus espaços, elas reestruturaram o espaço e definiram o discurso sobre a arte contemporânea". Chin-tao Wu, Privatização da cultura.
}

Após os dois casamentos, Allen apresenta uma exposição no museu. À primeira vista parece não haver relação entre os personagens e as pinturas expostas. No entanto, a cena mostra que o mundo das artes vincula-se ao universo das finanças. Em uma das salas do

\footnotetext{
${ }^{202}$ Simmel, op.cit., p.381.
} 
museu $^{203}$, o espectador observa um quadro e a voz de uma personagem desconhecida afirmando: "Você precisa ir a um médico especialista em fertilidade". Sem que possamos vêla, o espectador ouve a voz de Chloe responder: "Eu sei". Portanto, Allen apresenta a pintura antes das personagens. A esposa de Chris e uma amiga caminham em direção ao quadro, a primeira prossegue: "Nós já tentamos de tudo", referindo-se à concepção do filho. Ao aproximarem-se da tela, a colega de Chloe pergunta: "E quanto a isso?", apontando para a pintura. O filme ironiza as jovens endinheiradas, ao relacionar a concepção do filho com a imagem retratada nos quadros. Observando a tela de perto, a jovem Hewett critica: "Suas pinceladas são muito intensas, não são?”, a amiga avalia: “É verdade, eu não gostei”. Chloe concorda e caminha em direção à próxima tela.

Nesta cena, o espectador poderá notar que a visita à exposição feita pelas jovens endinheiradas difere da recepção dos visitantes comuns. Por meio do diálogo entre Chloe e a amiga é sugerido, na visita a Tate, a seleção e compra das obras pela herdeira para sua coleção. Todavia, o espectador observa que a avaliação artística feita pelas jovens, especialistas em arte, é rebaixada e desatenta (Figura 4). Apesar de serem potenciais compradoras das obras da Tate, as amigas preocupam-se mais com projetos de fertilização. Há um comentário irônico do filme sobre a maneira pela qual as jovens ricas observam os quadros no museu. A futura galerista Chloe e sua amiga demonstram a atitude típica de compradores diante das prateleiras de um supermercado, ou de um shopping center. A resistência à figuração, o embate com a produção de formas definidas, o uso de cores escuras e manchas, a pintura que revela o movimento feito pelo pintor - referência a um certo tipo de arte moderna $^{204}$ - são ignorados pelas jovens ricas que sentenciam "suas pinceladas são muito intensas" e "não gostei” ao passo que conversam sobre a concepção do herdeiro.

A inspiradora análise da pesquisadora taiwanesa Chin-Tao $\mathrm{Wu}$ sobre a privatização da cultura no Reino Unido e nos Estados Unidos servirá de base para as considerações a seguir sobre a intervenção corporativa nas artes. Tendo em vista a dificuldade de Chloe em gerar

\footnotetext{
${ }^{203}$ Todas as imagens das salas de exposição na Tate Modern foram filmadas no Ealing Studios, em Londres. Pode-se afirmar que a seleção das pinturas no filme não é casual, Allen selecionou cada um dos quadros.

${ }^{204}$ Em entrevista a Stig Björkman, Allen diz não se sentir influenciado por nenhum pintor norte-americano, contudo, no momento em que Björkman afirma lembrar-se do pintor Edward Hopper quando assiste aos filmes do cineasta, o diretor revela: "Sim, eu amo o Hopper, claro. Todos os norte-americanos amam o Hopper. Ele tem uma certa melancolia que eu gosto". Björkman retoma a pergunta: "Existem outros artistas norte-americanos que você gosta ou sente-se influenciado?" Allen afirma gostar de "todos os pintores abstratos e expressionistas como De Kooning, Jackson Pollock e Frank Stella". O cineasta acrescenta que adora diversos trabalhos de Andy Warhol, Rauschenberg e Jasper Johns. E conclui: "Sim, eu amo a pintura norte-americana contemporânea". Ver Björkman, op.cit., p.85.
} 
uma criança, a colega sugere: "Você já pensou em adotar?", a resposta da herdeira reitera a importância para os Hewett dos laços sanguíneos na transmissão da propriedade: "Não, de jeito nenhum, quero os meus próprios filhos". A amiga volta ao assunto dos quadros, apontando para outra tela, novamente observa-se a ironia entre a "escolha" do filho no projeto de fertilização e a avaliação/compra dos quadros: "E este aqui?" A pintura, semelhante à primeira, é rejeitada por Chloe que a classifica como "mais ou menos". O assunto da gravidez retorna ao centro da conversa: "Eu já lhe contei que a Victoria Phyfe está grávida?” A jovem herdeira interessa-se pelo assunto: "Verdade?" Chloe e a colega dialogam, esquecendo-se dos quadros, enquanto caminham por outras obras sem observá-las, concentrando-se apenas na conversa: "Ela está tão feliz. Ela e o marido se encontraram, todas as neuroses se entrelaçam e tudo funciona perfeitamente. Após tantas relações infelizes, eles se conheceram num acidente de trânsito". Aos olhos do espectador, o relato da colega de Chloe, entendido pelas personagens como exemplo de casamento bem-sucedido, figura como um comentário irônico de Woody Allen sobre os relacionamentos amorosos "bem-sucedidos" contemporâneos. Aos espectadores dos outros filmes do cineasta não passará despercebido que as neuroses dos personagens nunca resultaram em relações perfeitas.

Allen compõe a cena em um plano sequência que permite, novamente, que os atores sejam vistos em situação. Os quadros, os outros visitantes do museu e a conversa entre as amigas relacionam-se em cena. Enquanto as amigas conversam sobre gravidez e comentam a respeito das telas do museu, o espectador pode observar os outros visitantes: um casal aproxima-se da câmera, outro homem passa em frente à câmera, uma jovem observa um dos quadros. Por sua vez, Chloe e sua amiga passam sem observá-lo. Um senhor caminha em frente à câmera, enquanto Chloe e a colega deixam a sala do museu. Dessa forma, os outros visitantes do museu parecem chamar a atenção dos espectadores para os quadros e não para o diálogo entre as personagens. Como se resistisse à conversa das jovens, a câmera permanece no local mesmo após a saída das duas. A câmera permanece ao lado de uma jovem visitante desconhecida do museu que, diferentemente de Chloe e sua amiga, continua olhando atentamente para a pintura abstrata.

Apesar da visita à Tate Modern, feita por Chloe e sua colega, continuar, Allen corta para o arranha-céu na City, sede da Hewett Inco. Diferentemente de Tom, Chris não possui um escritório privado. A sala do protagonista no Swiss Re é compartilhada com os outros funcionários da empresa. A composição deste plano sequência permite que o espectador 
estabeleça relações entre o ambiente de trabalho do protagonista e seu discurso. A cena apresenta o ex-professor de tênis no edifício high tech durante o trabalho: "Nossos advogados estão resolvendo isso agora. Você terá uma ordem de pagamento na sexta, eu prometo. Se eu tiver que trabalhar durante toda a noite, ok. Obrigado." Chris, que se movimenta incessantemente, parece desinteressado pelo trabalho e angustiado. Ao desligar o telefone com força, ele tenta desapertar a gravata e procura respirar. Chris olha pela janela do edifício e quanto mais ele observa o abismo entre as estruturas triangulares e pontiagudas que formam o prédio e o skyline da City, pior ele fica. O escritório é coberto por vidros e não há divisórias entre os departamentos, de forma que todos os executivos que trabalham no local estão em constante observação. O protagonista sente falta de ar, levanta-se ofegante da cadeira e tenta não olhar para os lados. Ele caminha em direção à câmera e pede para a secretária trazer-lhe “duas aspirinas." Chris senta-se de costas para o precipício. A secretária entrega-lhe os comprimidos e pergunta se o chefe está bem. Novamente, o executivo desaperta a gravata e, sem responder à pergunta da secretária, mas suando frio, indaga se a funcionária "nunca se sentiu claustrofóbica" no local. Nesse ponto, Allen focaliza em Chris e a sensação de aprisionamento é intensificada pela câmera.

Após tomar os remédios, o protagonista olha para o relógio e levanta-se da cadeira: "Oh, Cristo! Tenho que encontrar a minha esposa na Tate Modern, tem um novo pintor que ela quer me mostrar”. Dirigindo-se à secretária, mas sem que possamos vê-la, Chris avisa que se os clientes ligarem para ele, a funcionária deve avisá-los de que "será na sexta, não antes. Boa noite." Ainda no edifício de negócios, a ópera $O$ Elixir de Amor invade a ação e acompanha a cena seguinte, onde se observam os arredores fabris da Tate Modern ${ }^{205}$.

\footnotetext{
${ }^{205}$ O projeto arquitetônico de reconstrução da Tate Modern foi composto pelo famoso escritório suíço Herzog \& de Meuron. A aparência fabril do local, onde funcionara uma usina de energia, foi preservada. O Turbine Hall serve de entrada para o museu, bem como para exposições de grandes esculturas. As galerias do museu ocupam o espaço da antiga casa das caldeiras. As galerias estão dispostas em blocos distintos, mas separados, conhecidos como suítes, em cada um dos lados das escadas rolantes centrais. A coleção de arte moderna da Tate ocupa dois dos andares das galerias e o terceiro é dedicado às exposições temporárias. A chaminé da antiga usina de energia foi coberta por um recurso de luzes coloridas, desenhadas pelo artista Michael Craig-Martin, conhecida como Swiss Light. À noite, os raios da torre e a Swiss Light marcam a presença da Tate Modern por muitos quilômetros. Disponível em: 〈http://www.tate.org.uk/modern/building/〉. Acesso em: 3 fev. 2010. Para uma abordagem crítica da renovação da Tate e da parceria público-privada envolvida no negócio, a pesquisadora Chin-tao $\mathrm{Wu}$ explica que os lucros das corporações envolvidas na reforma foram bastante expressivos: "A ambição 'expansionista' da galeria é mais evidente no grande esquema da Tate Modern, inaugurada em maio de 2000 na usina abandonada de Bankside, no Tâmisa. Para realizar esse plano, que custou cerca de 134 milhões de libras, a Tate lançou uma gigantesca campanha de arrecadação para atrair dinheiro privado e completar os 68,2 milhões de libras já oferecidos pela Comissão do Milênio e outras instituições públicas. Em troca de uma doação generosa, de 1 milhão a 10 milhões de libras, as pessoas poderiam comprar a "imortalidade" dando seus nomes às galerias da Tate Modern." Ver Chin-tao Wu, op.cit., p.160.
} 
Novamente, a fachada do edifício é apresentada em primeiro lugar, como se rememorasse a história e o local do museu.

O carro da empresa, utilizado por Chris, chega ao local, o protagonista sai do veículo e caminha em direção ao museu, enquanto o espectador pode observar uma pequena torre luminosa onde está escrito o nome da Tate. No interior do museu, o executivo percorre os corredores do local. Podem-se observar os outros visitantes e as informações sobre as exposições. A música extra-diegética acompanha a cena. No canto direito da tela, por meio de um bloco esfumaçado de vidro, o espectador pode acompanhar Nola descendo as escadas rolantes. Ao reconhecer Nola, Chris para em frente à parede vidro de costas para o público. O espectador pode observá-lo por meio do reflexo no vidro escuro, como se fosse uma sombra. A câmera muda de posição e encara o protagonista que a encontrou por acaso. Chris corre em busca de Nola. A vivacidade do protagonista é ressaltada pela montagem e contrasta com a morosidade do ritmo na cena em que Chloe e a amiga passeiam pelo museu. Ao ver Nola, Chris chega a colidir com um visitante do museu. Nesse ponto, o espectador percebe o contraste entre o tédio ao lado de Chloe, a sensação de claustro e angústia no Swiss Re e o vigor do tenista ao deparar-se com Nola.

Além das sombras proporcionadas pelo reflexo do vidro, a câmera passa por pilastras do museu, o que confere certo distanciamento em relação ao olhar do protagonista. Em um ambiente escuro, o interior da Tate, o protagonista aproxima-se do vão do edifício. Ele observa Nola do andar de cima do museu (plongée), ao passo que a jovem norte-americana caminha como os outros visitantes, sem saber que está sendo observada. Chris desce as escadas à procura de Nola. Apesar de Chris ter seguido em outra direção, o olhar da câmera permanece na escada, sem que se possam ver os personagens. Ouve-se a voz da esposa de Chris. Nesse momento, a ópera é cortada. O tenista surpreende-se com o encontro: "Oh, eu estava te procurando". Alguns visitantes do museu passam pela câmera que continua parada em frente à escadaria escura do museu. A câmera, portanto, não acompanha o movimento do protagonista. Sem que possamos vê-los, os personagens cumprimentam-se, ouve-se o nome da amiga de Chloe, Carol. Dessa maneira, por meio da composição da cena na escada, Allen retoma a ideia de um cerco, do controle dos passos do protagonista pela família Hewett. Assim como o acaso serve para caracterizar o encontro entre Nola e Chris, a eventualidade também surpreende o protagonista que é interceptado pela esposa. As sombras e a escuridão 
na composição desta cena indicam, entre outros aspectos, que o protagonista está mentindo para Chloe.

Após o encontro entre Chris e Chloe, os personagens retornam para frente da câmera. Chloe, que parecia não interessar-se pelas obras expostas no museu, conta ao marido que a Tate "tem os melhores novos artistas." Carol diz à amiga que quer que ela "veja essa mulher da St. Ives" ${ }^{206}$. A herdeira entusiasma-se com a sugestão da colega. Ao perceber o interesse da jovem Hewett pela exposição, o tenista inventa uma desculpa, relacionada novamente ao trabalho, no intuito de despistar a esposa: "Preciso fazer uma ligação e estou sem sinal aqui". Nesse ponto, o ambiente corporativo retorna à cena. Chloe pede para que o marido não demore: “Corra, porque eles estão fechando". Chris promete que será rápido. Após a saída de Chloe e Carol, a música extra-diegética é retomada como se rememorasse que o interesse do protagonista permanece em Nola e avisasse se tratar novamente de um "elixir". Novamente, o espectador observa a simulação do protagonista. Para dar a impressão à esposa de que está sem sinal, Chris finge telefonar. Novamente, ele esconde-se atrás da escada, local em que Chloe não pode vê-lo. A câmera mantém-se afastada do protagonista com o foco na escura escadaria.

A cena é cortada para as galerias do museu. Em uma das salas de exposições, pelas quais o protagonista passa, encontram-se as obras as quais anteriormente Chloe e Carol "não gostaram". Por sua vez, os outros visitantes do museu admiram as pinturas expostas. O filme apresenta uma galeria do museu, onde podem ser observadas, em primeiro plano no canto direito da tela, uma pintura semelhante a uma fotografia da fachada de um prédio. Quando Chris aproxima-se da câmera, ela afasta-se do protagonista, deixando o quadro em evidência. O protagonista passa em frente à câmera em busca de Nola, outros visitantes interpõem-se à visão do protagonista. Nesse momento, o espectador poderá ler a indicação do autor das pinturas no canto direito da tela, trata-se de David Hepher (Figura 5). A série de pinturas, apresentada no filme, retrata blocos de prédios conhecidos como Albany Flats, do pintor David Hepher: "Durante os anos de 1969 e 1974, Hepher fez pinturas a partir de uma meticulosa análise das fachadas das casas de subúrbio em Londres e descreveu os blocos de prédios como 'uma espécie de subúrbio no centro da cidade (que talvez) abrigue as próximas

\footnotetext{
${ }^{206}$ A ironia de Allen é explícita com o comentário de Carol que anteriormente afirmara não gostar de arte abstrata. Ao indicar uma artista da St. Ives, a jovem endinheirada não associa a escola que sempre foi identificada com os artistas que exploraram o potencial da arte abstrata. Informações sobre a St. Ives podem ser encontradas em: <http://www.tate.org.uk/stives/art-in-stives/>. Acesso em: 3 fev.2010.
} 
gerações de pessoas que viveram nas casas suburbanas antes da guerra que eu costumava pintar. ${ }^{, 207}$ Hepher oferece o contraponto aos prédios de negócios como o Swiss Re: "Eu só pinto prédios residenciais - eles têm uma alma que os escritórios glamorosos não têm. Apesar de sua beleza, eu não quero pintar os blocos de prédios requintados e brilhantes da cidade." $\mathrm{O}$ artista considera que "um dos perigos inerentes em escolher um assunto aparentemente banal como os blocos de prédios é que a pintura resultante pode ser entendida como um discurso sobre a banalidade. Ele evita isso concentrando-se na maneira em que a fachada superficialmente unificada do prédio aparece rachada ou alterada por intervenções dos seus habitantes como, por exemplo, vasos de plantas, enfeites, caixas nas janelas, os padrões e as texturas diferentes das cortinas e etc. [...]"208.

Em outra galeria, observa-se ao fundo, de costas para a câmera, a personagem Nola em frente a um quadro. A câmera para e muda de posição enquanto Chris observa a jovem norteamericana. Desse longo plano-sequência, conclui-se que assim como Nola, os visitantes comuns examinam as pinturas conferindo as informações no catálogo da exposição e detendose atentamente em cada um dos quadros, o que contrasta com a falta de interesse de Chloe, Carol e Chris. Na cena do reencontro entre Nola e Chris, o cenário é composto por quadros em que figuram os prédios dos subúrbios em Londres, paisagens que por se tratarem de periferias recordam a origem do jovem irlandês pobre e da atriz faminta norte-americana de Boulder, Colorado. O cenário retratado pelas pinturas afasta-se das opulentas propriedades da família Hewett no campo e na cidade.

Nesse ponto, a voz de Caruso em "Uma Furtiva Lágrima"209 ilustra os pensamentos do protagonista: "Céus, depois posso morrer / posso morrer de amor", momento em que Nemorino implora pelos suspiros da amada. No entanto, no filme, o amor evocado pela música extra-diegética contrasta com a pintura. Nola observa o quadro sem se movimentar e no topo da tela pode-se ler a palavra "ache" (dor, em inglês). As cores fortes e os movimentos bruscos retratados na pintura, desta vez, fazem lembrar um cenário de guerra (Figura 6). A exnoiva de Tom olha em direção às outras obras. Neste momento, Nola percebe que Chris vigiaa. A ópera é interrompida. A expressão da norte-americana assemelha-se ao quadro ao fundo, pois ela parece intimidar-se com o encontro. Por sua vez, o protagonista avança em direção à

\footnotetext{
${ }^{207}$ David Hepher, 'Urban Realism', Artscribe No.22, abril 1980, p.48.

${ }^{208}$ Disponível

em:

em

$<$ http://www.Tate.. rg. uk/servlet/ViewWork? cgroupid=999999961\&workid=5963\&searchid=10870\&tabview=te xt>. Acesso em: 13 fev. 2009.

${ }^{209}$ No original em italiano, "Una furtiva lagrima", ária da ópera L'elisir d'amore.
} 
Nola. O reencontro entre os dois é feito com o cenário de guerra, sugerido pelo quadro, ao fundo. O executivo inicia a conversa, enquanto Nola mantém o olhar taciturno e prefere manter distância em relação a Chris:

[Chris Wilton]: "Olá. Que surpresa."

[Nola Rice]: "É. Eu voltei para a cidade."

[Chris Wilton]: "Eu não sabia que você tinha ido embora."

[Nola Rice]: "Claro, eu estava muito chateada com tudo o que aconteceu, então, eu voltei para os Estados Unidos para procurar um emprego."

[Chris Wilton]: "Achei que você odiava aquele lugar."

[Nola Rice]: "Qualquer lugar menos aqui."

[Chris Wilton]: "Eu te procurei."

[Nola Rice]: "Para quê?"

[Chris Wilton]: "Você ainda está tão brava. Onde você mora?"

[Nola Rice]: "Na cidade. Por quê?"

[Chris Wilton]: "Você mora sozinha?"

[Nola Rice]: "Por que você está fazendo estas perguntas, não está casado ainda?"

[Chris Wilton]: "Posso te encontrar para uma bebida? Conversa? Onde posso encontrá-la? Vamos."

O diálogo é filmado em campo/contra-campo. Quando Nola dirige-se a Chris, o espectador observa as pinturas dos subúrbios de David Hepher; no momento em que o irlandês encara a norte-americana, vemos o quadro que faz referência à guerra. Os quadros escolhidos por Allen resgatam a história dos dois personagens. Eles seriam uma espécie de comentário que oferecem ao espectador certa tensão, por apresentar a periferia e o cenário de guerra, em relação à imagem do jovem executivo engravatado. Além da referência às guerras recentes, comandadas pelos norte-americanos e apoiadas pelos britânicos, o cenário de luta retoma também o jogo entre Nola e Chris, no qual a norte-americana fora eliminada por Tom.

Chloe surpreende o marido e a ex-cunhada. O olhar da câmera vai para a jovem Hewett que caminha em direção à câmera. Apesar do rosto triste de Nola, Chloe considera que a norte-americana "está ótima". A ex-noiva de Tom pergunta por ele, Chloe informa que o irmão "está muito bem, eles têm um filho, você o conhece, ele já se ajeitou". Aos olhos do espectador, a despreocupação de Chloe contrasta com a dor de Nola. Carol aproxima-se da amiga para contar que encontrou a exposição que procuravam e Chloe apresenta Carol a Nola. A jovem Hewett explica que tentava encontrar uma instalação de vídeo, ela pede licença ao marido e à ex-noiva do irmão. Chris aproxima-se de Nola, todavia, Chloe e Carol continuam muito próximas aos dois. O protagonista pede para que Nola diga o seu telefone, a atriz reluta, 
mas acaba cedendo, sussurrando o número ao executivo. Chris responde que entrará em contato e caminha em direção à esposa. Nola permanece sozinha no museu.

Na cena seguinte à da Tate, Allen apresenta novamente o carro da empresa e a fachada de uma residência distinta, semelhante à casa da cidade dos Hewett. O espectador atento poderá notar que se trata de um local elegante, bastante diverso das fachadas dos prédios nos subúrbios londrinos representados por Hepher. Chloe sai da residência e Chris acompanha-a. A esposa afirma que "acha que ele sabe o que está fazendo" e pergunta ao esposo se Chris teve uma boa impressão. O protagonista diz que em sua opinião "os médicos especialistas em fertilidade são como médicos bruxos". Chloe concorda, mas considera que "este não é como aquele último". Ela entra no carro, onde está o motorista. A jovem herdeira entusiasma-se com a consulta: "Eu sinto que vai acontecer desta vez". Chris dispensa a esposa: "Você pode ir, eu tenho algumas reuniões". De forma precisa, Allen associa o ambiente do trabalho e o projeto de fertilização - ambos os atributos necessários para a continuidade do protagonista na família - e retoma a indicação de Carol no museu, que sugerira à amiga um especialista. A cena revela também, a passagem do tempo, pois o casal já esteve em diversos consultórios médicos em busca de técnicas de reprodução assistida. Na passagem desta cena para a próxima, expõe-se, aos olhos do espectador, o contraponto entre a monotonia do protagonista ao lado de Chloe e a impetuosidade de Chris com Nola. Chris sai da clínica de fertilização e vai encontrar Nola.

Novamente, o encontro entre Nola e Chris faz-se em um dia chuvoso. Por meio de um espelho, o espectador observa Chris e Nola. Depois, a câmera focaliza os amantes, o executivo rasga as roupas de Nola e beija-a. Deitado na cama, Chris afirma que o apartamento da norte-americana "é muito charmoso, não é tão precário quanto você falou". Em contraposição a Chris, a descrição do edifício feita por Nola faz lembrar os apartamentos do subúrbio londrino, conforme retratados por Hepher: "Eu tive sorte em encontrá-lo tão rápido. Não é perfeito, o prédio foi assaltado algumas vezes e a vizinha da frente encontrou ratos, mas a entrada é decente. A palavra-chave é que é barato." Chris sorri e pergunta o horário à amante, ela diz: "Já está na hora de você ir.", o que indica que este não seria o primeiro encontro. A decoração do quarto de Nola é composta por diversos objetos que remetem à beleza: fotografias de mulheres, flores, quadros e pequenas esculturas femininas. Chris beija a amada e afirma: "É tão difícil ter que te deixar. Linda mulher." 
O desejo e a violência demonstrados pelo protagonista no apartamento da amante contrastam com a falta de interesse na conversa banal com a esposa durante o café da manhã. O pequeno apartamento de Nola, localizado em um bairro violento, remete à primeira residência do tenista. As duas residências nos subúrbios opõem-se imediatamente ao suntuoso Parliament View Apartments. O casal toma café da manhã com vista para o rio Tâmisa, o Parlamento Britânico e o Big Ben na iluminada ${ }^{210}$ sala da residência ${ }^{211}$. A intimidade entre o protagonista e a amante contrasta com a distância entre Chris e Chloe: sentados cada um em uma das extremidades da mesa, o casal troca poucas palavras. A jovem herdeira quer saber como o marido dormiu, ele limita-se a respondê-la. Chris come como se estivesse ciscando (assemelhando-se ao galo representado no quadro que está atrás do protagonista).

A esposa relata as notícias ao marido: "Você viu aquela notícia ontem à noite sobre aquele terremoto na China? Hum.” A tragédia no Oriente não provoca reação em Chloe e Chris que apenas grunhem. Todavia, apesar do aspecto corriqueiro, característico das notícias, o comentário de Chloe ganha sentido forte quando relacionado à central importância que, para uma empresa de resseguros como a Swiss $R e$, o cálculo dos riscos de desastres naturais representa $^{212}$. À primeira vista, as notícias parecem desprovidas de qualquer aproveitamento, no entanto, podemos ler a torrente de informações produzidas pela mídia à maneira de Benjamin, buscando encontrar "a relação real dessas informações com a existência social [que] está determinada pela dependência dessa atividade informativa face aos interesses da Bolsa e por sua repercussão sobre eles." ${ }^{213}$

O desinteresse do marido não impede a jovem Hewett de continuar comentando a respeito das notícias: "E agora tem toda essa discussão de que descobriram um novo planeta." Chris limita-se a ciscar o pão e concordar com a mulher. $\mathrm{O}$ aspecto repetitivo, cotidiano e banal da conversa assemelha-os às notícias de jornal. Embora a falta de entrosamento entre o casal seja evidente, Chloe prossegue relatando as novidades ao marido: "Ontem, saí para

\footnotetext{
${ }^{210} \mathrm{Em}$ Londres, que é conhecida por seus dias cinzentos, a entrada de luz nos apartamentos da cidade é um elemento bastante valorizado no mercado imobiliário.

${ }^{211}$ A inauguração do Parliament View Apartments recebeu ampla cobertura da mídia inglesa, o edifício é considerado como "uma das melhores vistas de Londres". Disponível em: $<$ http://www.dailymail.co.uk/news/article-1084174/Two-mortgages-Prezza-How-credit-crunch-lose-JohnPrescott-200-000-luxury-London-flat.html $>$. Acesso em: 13 jan. 2010.

212 "A gestão de riscos de catástrofes naturais é essencial para o futuro crescimento e desenvolvimento da economia chinesa", diz Franz-Josef Hahn, Membro do Grupo Executivo Ásia \& Grande China da Swiss Re Propriedade \& Danos. "Os dados deste Atlas propiciam uma referência científica para ajudar a indústria de seguros a avaliar e antecipar riscos de catástrofes naturais e desenvolver soluções de proteção", acrescenta Hahn.Disponível em: <http://www.swissre.com/>. Acesso em: 6 jun. 2009.

213 Benjamin, op.cit., p.225.
} 
procurar um espaço para a nova galeria. O papai está gostando tanto da ideia.” Nesse ponto, o espectador percebe que a galeria de arte será um investimento do patriarca. O entusiasmo de Alec em patrocinar a filha para montar uma galeria pode ser entendido no próprio contexto da empresa, configura-se como promoção de sua imagem corporativa. Nesse sentido, retomaremos o argumento de Chin-tao Wu: "Num mercado global de forte competição, em que os produtos e serviços se tornam a cada dia menos distinguíveis, a única maneira de uma companhia se diferenciar dos competidores é ter uma imagem corporativa "esclarecida". E a arte, ou as artes em geral, é extremamente adequada à promoção". ${ }^{214}$

Enquanto o patriarca pensa nos negócios, Chris considera que a ocupação será uma boa oportunidade para distrair os pensamentos da esposa. Ele olha para o relógio, mostrando mais uma vez o desinteresse por Chloe, e informa à esposa que precisa ir para o escritório. Preocupada com a concepção do herdeiro, Chloe pede para que Chris fique um pouco em casa para que possam dar prosseguimento ao projeto de fertilização: "Eu esperava que a gente poderia, você sabe, antes de você sair para o trabalho. Estou no meu período fértil e lembre-se que o médico disse que a gente deveria tentar muito, quantas vezes fossem necessárias, pela manhã.” A solicitação, com recomendações médicas, é o avesso do desejo de Chris por Nola. O protagonista tenta livrar-se da esposa, utilizando novamente a desculpa relacionada ao trabalho: "Eu vou me atrasar, querida." No entanto, a herdeira persiste: "Vamos, vai ser divertido". A ironia de Allen na cena é explícita:o fastio da conversa, o pijama de Chloe, a falta de assunto entre o casal, a ausência de qualquer possibilidade de prazer sexual em um "projeto de fertilização" corroboram para a inexistência do desejo e sugerem a ideia de uma atividade mecânica, na qual os dotes físicos do tenista servem aos intuitos de reprodução da família. Até mesmo a voz da herdeira entedia quando ela pede para que o marido aguarde um pouco para que ela meça sua temperatura. A personagem coloca o termômetro na boca e cronometra o tempo, enquanto o tenista termina o café. $\mathrm{O}$ ato sexual reificado salta à vista.

A atividade prescrita por uma equipe médica, controlada e rigidamente seguida por Chloe é seguida pela paixão desmedida na relação com Nola. A amante pergunta se eles voltarão a se encontrar "no mesmo horário na semana que vem". No entanto, o protagonista afirma que quer subir: "Não consigo evitar, você me deixa louco". Sem medo de ser surpreendido, Chris beija Nola na calçada, enquanto outros transeuntes passam. A amante

\footnotetext{
${ }^{214}$ Ver Chin-tao Wu, op.cit., p.277.
} 
avisa que o executivo se atrasará para o trabalho. A referência ao trabalho que fora utilizada como desculpa pelo protagonista para libertar-se da esposa perde a importância para Chris quando está com Nola.

No corredor do prédio, o casal é surpreendido pela Sra. Eastby. A vizinha explica à norteamericana que as "armadilhas para ratos funcionam melhor com manteiga de amendoim. É muito melhor do que queijo, apesar do que todos pensam." A referência ao famoso alimento proveniente dos Estados Unidos seria uma pista para o espectador de que a norte-americana pode servir como isca para ratos. No entanto, para Nola o aviso passa despercebido e Chris é apresentado à vizinha como sendo o Sr. Harris. Ao entrarem no quarto de Nola, os suspiros e o furor da relação entre os estrangeiros retornam ao filme. Nola retira a gravata, venda os olhos do amante e desabotoa a camisa do executivo. No plano seguinte, Allen apresenta novamente o contraponto entre o tédio ao lado dos Hewett e o entusiasmo com Nola, demonstrados nas cenas anteriores. Em um restaurante luxuoso, observamos Tom e sua esposa. O jovem Hewett acredita que a Bruton Street $^{215}$ será perfeita para sediar a galeria da irmã: "Fica no lugar certo e será um sucesso natural na minha opinião, porque você é ótima para escolher pinturas e cacarecos". Para Chin-tao $\mathrm{Wu}$, o patrocínio das artes por empresas é entendido como um investimento: "O engajamento dessa elite empresarial nas artes pode ser interpretada então nos níveis individual e corporativo. [...] Em virtude de seu ambiente social e de sua posição corporativa, eles participam de uma rede intricada e complexa de relações econômicas e sociais de conhecimentos, amizades e casamentos. Entretanto, a riqueza herdada ou obtida com empregos de alto status, como afirmou Throstein Veblen no século XIX, não constitui por si só uma credencial suficiente para participar da seção dominante da classe. Isso depende também da adoção e demonstração de um conjunto particular de valores e estilos de vida. Ser visto como patrono das artes é parte de um estilo de vida distinto exigido e sancionado no interior desse estrato "sofisticado" da sociedade. O exercício da alta cultura tornou-se uma parte cada vez mais importante da atividade social: é principalmente nos eventos artísticos exclusivos que a elite empresarial e política se reúne e se reconhece. Não é surpresa que os nomes dos executivos estejam sempre associados ao patrocínio das artes nas reportagens da mídia." 216

\footnotetext{
${ }^{215}$ A Bruton Street é conhecida por suas galerias de arte, entre elas: Sotheby's, Whitfield Fine Art, Hamiltons Gallery etc. Disponível em: 〈http://www.galleries.co.uk/g-nbs.htm〉. Acesso em: 13 jan. 2010.

${ }^{216}$ Chin-tao Wu, op.cit., p.149-150.
} 
A escolha da Bruton Street, localidade que garante o sucesso certeiro da galeria, é revelada no encontro dos casais em um luxuoso restaurante, característica que retoma os lugares de alto consumo frequentados pelos irmãos Hewett. Como também, revela que a localidade está ligada ao status social e relaciona a galeria de arte ao investimento corporativo dos Hewett. Segundo Chin-tao Wu, "a ligação entre arte, poder e prestígio social sempre foi coerente desde a Renascença, e seria ingenuidade supor que o papel da arte no meio comercial e empresarial pudesse deixar de ser o de um valorizador de status"217.

A cena é semelhante a do restaurante em que Chris e Nola trocam olhares. Entretanto, casado com Chloe e sem a presença de Nola, Chris limita-se a murmurar, restringindo-se a pequenos comentários. A linhagem familiar parece ser o ponto alto da conversa: Chloe comenta que seus planos em ter um filho podem atrapalhar o trabalho na galeria. Heather e Tom discordam, defendendo os atributos da mulher contemporânea que "não tem problemas em conciliar o trabalho com a maternidade". Todavia, a própria fala dos personagens contém a sua negação: as esposas que conseguem perfeitamente acomodar o trabalho com os afazeres domésticos são aquelas que, assim como Heather, contam com a ajuda de uma babá. Apesar de dispor de uma ajudante, a esposa de Tom relata à cunhada que infelizmente "a babá nos deixou, pois conseguiu um papel em um filme". Chloe, que sempre foi afeita ao mundo do entretenimento, interessa-se pela história. Tom complementa o assunto ao lembrar que encontrou sua ex-noiva, a atriz Nola: "Ela está trabalhando agora em uma loja na Ledbury Road. Acho que é a Paul and Joe's. Mas, ela é uma garota tão estranha. Ela ainda é muito bonita, desculpe-me, mas é verdade. Mas alguma coisa mudou no rosto dela e a gente mal se falou." Enquanto Tom relata o reencontro, o olhar da câmera focaliza a reação de Chris e Chloe. O protagonista finge não se interessar pelo assunto e Chloe presta atenção à reação de Tom.

Por acaso, um casal de amigos dos Hewett aproxima-se da mesa e o amigo de Tom revela ter encontrado Chris "pegando um táxi na Melcombe Street, às cinco da tarde". Tom e Chloe desconhecem a localização da rua, o que indica tratar-se de local diverso ao frequentado pelos irmãos Hewett. A característica pontualidade britânica, e o nome da rua fornecido pelo amigo dos Hewett não servem como evidências contra o cheio de credenciais Chris. Diferentemente do espectador, os irmãos Hewett não desconfiam do protagonista. Chris convence a todos na mesa: "Você está enganado, mas obrigado por pensar em mim." 
Tom ri da conversa: "Acho que a única informação que podemos tirar daqui é que vocês dois são malucos." Os amigos combinam um passeio na casa de campo e o casal de amigos dos Hewett retira-se da mesa. Portanto, o encontro entre os amigos, que não é casual no filme, é mais um indício para o espectador da confiabilidade que o protagonista desperta para a família Hewett.

A rotina de Chris não se altera. De volta ao escritório no Swiss Re, o executivo pergunta à secretária por seus compromissos do dia. Na mesa de Samantha, o espectador pode identificar o setor da empresa em que Chris trabalha: "Infra-Estrutura Global e Finanças". O desinteresse de Chris pelos negócios da empresa é novamente ressaltado. O protagonista pede para que a secretária adie seus compromissos. No escritório sem paredes, o colega de trabalho, Rod Carver, repreende a saída de Chris: "Nós temos o Sarazin e a empresa dele nesta tarde". Todavia, Chris que é genro do dono da empresa diz que tem um compromisso importante.

Na cena seguinte, Allen revela o compromisso importante. O executivo encontra Nola em um bar. Os relatos de Chris sobre o tédio no escritório e ao lado da família Hewett fazem com que Nola fique aborrecida. Ela revela estar cansada também de tentar ser atriz: "Não está funcionando. [...] A mãe do Tom estava certa, chega um momento que não dá mais, sabe?” Os dois discutem, Nola diz que não sabe o que está fazendo com Chris já que o tenista nunca vai deixar a esposa. O protagonista afirma que talvez abandone Chloe. Diferentemente dos Hewett que não duvidam de Chris, Nola sabe que ele pode estar mentindo: "Não diga isso a não ser que seja verdade". O tenista volta a reclamar do casamento: "Chloe está tão desesperada para engravidar, é mecânico. Não sei o que faria se não pudesse ver você. De verdade, é sério."

Na sucessão das cenas - na Tate, no Parliament View, no restaurante, no Swiss Re - as atividades repetitivas, o ambiente de esgotamento e a expressão de tédio do protagonista reaparecem. Em cada um desses momentos, Allen oferece a contraposição, entrecortando a cada uma dessas cenas, os encontros com Nola - na Tate, no apartamento do subúrbio, na calçada em frente ao prédio de Nola e por fim, no bar - em que a vivacidade do tenista volta à tona. Desse modo, na cena do bar, esboça-se a possibilidade de mudança. O protagonista poderia abandonar a esposa, libertando-se do claustro.

O passo seguinte, no entanto, indica que Chris permanecerá entre os Hewett. Eles comemoram o Natal na residência londrina da família. A árvore de Natal, os móveis antigos 
da família, a lareira, as pinturas naturalistas de paisagens inglesas compõem o cenário da casa londrina dos Hewett que se assemelha à decoração interior da casa de campo. A matriarca controla o comportamento dos filhos: "Por favor, Tom, não comece a fumar, é uma pena. Se você acha que vai viver para sempre...”. A câmera movimenta-se pela sala da residência e mostra uma pintura a óleo, retrato ancestral da matriarca. $\mathrm{O}$ olhar da câmera permanece no quadro. Todavia, ouvimos Chris. Nesse momento, a câmera localiza o protagonista que está no topo da escadaria da residência. Ele conversa com Nola por telefone, desejando-lhe boas festas e diz que tentará visitá-la no dia seguinte. Na escadaria da residência, Alec encontra o genro: “Aí está você, Chris. Chloe me disse que você perdeu algumas quantias pessoais de dinheiro na bolsa de valores nos últimos meses." Os dois descem as escadarias juntos, ao passo que o protagonista justifica-se para Alec: "Acho que eu fui um pouco descuidado, desconcentrado e é claro que eu pensei que tinha tomado boas decisões, mas...” As operações arriscadas realizadas por Chris no mercado financeiro recebem a proteção do patriarca: "Quem poderia prever isso? Olha, eu não quero que você e a Chloe se preocupem, vocês terão sempre uma rede de proteção." A descrição do "descuido e descontrole" de Chris nos investimentos, bem como as perdas financeiras encobertas pelo sogro antecipam o momento da crise financeira, ocorrida em 2008, que afetou os grandes bancos, as empresas seguradoras multinacionais e as economias nacionais, por conta justamente da desregulamentação do mercado e das operações desmedidas travadas por executivos no mercado financeiro. $\mathrm{O}$ movimento repete-se nas artes, conforme podemos observar a partir da análise de $\mathrm{Wu}$ : "Com os olhos voltados para a especulação, é razoável supor que as agências financeiras não perderam de vista o crescimento sem precedentes e às vezes errático dos preços da arte"218. Da mesma forma como oferece o patriarca, no caso da crise de 2008, os cofres públicos serviram como "rede de proteção" ao capital especulativo.

No filme, o executivo agradece a compreensão do sogro: "Você é muito generoso". Para o patriarca, todavia, não se trata de generosidade: "Você faz a Chloe feliz e isso é muito importante para mim e a Eleanor". Nesse ponto, as pinturas a óleo retratando as paisagens inglesas e o quadro da majestosa matriarca, além de remeterem à casa de campo e ao poderio ancestral da família Hewett, antecipam o controle e o domínio da matriarca e do patriarca na família. Além da amiga, do irmão, da cunhada de Chloe e dos médicos especialistas em fertilização, Alec e Eleanor cuidam para que o herdeiro de Chloe seja concebido.

${ }^{218}$ Chin-tao Wu, op.cit., p.258. 
Entretanto, o protagonista escapa aos desígnios da família. Novamente, Allen oferece o contraponto à família Hewett. Assim como a chuva estava presente no encontro entre Nola e Chris no campo de trigo e no apartamento do subúrbio, nesta, a neve pode ser observada pela janela do quarto de Nola. A comemoração natalina com Nola indica que o protagonista pôde sair do cerco dos Hewett por algum momento para ficar com Nola. Na cena, sem diálogos, a câmera observa Chris e Nola como um voyeur. A utilização da música extra-diegética retorna ao filme: enquanto Chris massageia Nola à luz de velas, pode-se ouvir os chiados da gravação antiga da ária "Mi par d'udir ancora" da ópera I Pescatori di Perle, de Georges Bizet, que já fora utilizada para caracterizar o desejo de Chris por Nola na cena em que se encontram por acaso em uma rua em Londres, onde o protagonista compra roupas parecidas com as de Tom.

A maneira como Allen indica a passagem do tempo no filme é exposta na junção das três cenas: os enfeites natalinos na casa londrina dos Hewett e a neve no apartamento de Nola caracterizam o inverno; em seguida, Allen apresenta a chegada da primavera por meio dos jardins floridos da casa de campo. A cerimônia do chá nos jardins da propriedade retoma a paisagem bucólica das pinturas a óleo presentes na casa londrina dos Hewett.

Sentados à mesa, os jovens ingleses abastados combinam uma viagem. A conversa não envolve o irlandês que se limita a respondê-los. Chloe revela ao grupo que o marido "nunca esteve nas ilhas gregas". A informação causa surpresa aos amigos endinheirados dos irmãos Hewett. No intuito de não rebaixar-se em frente aos convidados, o irlandês e ex-tenista profissional afirma que já esteve em Atenas e que ouviu dizer que as ilhas gregas são paradisíacas. Tom recorda-se de que eles precisam ir à Sardenha "para visitar Brook and Dougie Wilson". Ao apresentar o roteiro dos jovens endinheirados, Allen mapeia o circuito do turismo de luxo e retoma os atributos do protagonista, presente no currículo do professor de tênis que fora aceito pelo Queen's por ter experiência em clubes exclusivos situados na Sardenha, em Marbella e Nice.

Apesar de Chris tentar mesclar-se às classes dominantes, a diferença de classe é ressaltada pelos irmãos Hewett. Chloe retoma o assunto da gravidez: "Eu comprei ao Chris um amuleto grego da fertilidade." Chris diz à esposa que "nunca se esquecerá" do presente. O caráter cômico volta à cena, pois sabemos que o protagonista está enfadado com a obsessão de sua esposa no projeto de fertilização. Tom humilha o cunhado irlandês: "Eu acho que ele tem pouco esperma." O telefone do protagonista toca e ele afasta-se dos convidados para atendê-lo. Nola pede para que ele retorne à cidade. Ouvimos Chloe dizer que quer conhecer 
“Barbra Streisand”. Novamente, o fascínio pelo showbusiness volta a caracterizar os jovens ricos.

Na sala de jantar da casa de campo Eleanor e Alec, Tom e Heather, Chloe e Chris conversam durante o suntuoso jantar à luz de velas ${ }^{219}$. O patriarca informa que na manhã seguinte todos devem acompanhá-lo para cavalgar: "Comprei lindos cavalos novos". Tom provoca o cunhado: "Vocês lembram quando o Chris chegou aqui ele não conseguia cavalgar?" Chloe defende o marido: "Esta manhã ele estava pensando em comprar um cavalo para ele. Eu acho que a vovó tem uma boa égua." A governanta da casa interrompe o jantar para que Chris atenda ao telefone: "Ela disse que era importante.” A interrupção desagrada à família, Chloe diz que o maldito telefone não parou de tocar durante todo o fim de semana. Por telefone, Chris repreende a amante "Está louca, ligando-me aqui?". Nola avisa que está grávida. Novamente, nenhum dos integrantes da família suspeita de Chris. Eles conversam sobre assuntos triviais: Tom comenta sobre o cavalo que a família comprará para Chris, Chloe refere-se a "falta de vegetais", Eleanor faz menção a "limões, laranjas e biscoitos" e Tom explica a origem da bebida Rose's Lime Cordial.

Quando Chris retorna, Chloe quer saber quem "não pára de ligar". Aos olhos dos presentes à mesa, o protagonista diz que sua secretária pediu para que ele voltasse à Londres para assinar "alguns papéis". O herdeiro das empresas Hewett Inco. sabe que a secretária de Chris "foi passar o fim de semana com os pais". Todavia, Chris consegue convencer a todos: “Eu sei, isso é minha culpa, coitada". O patriarca defende o genro: "É um azar, mas Chris tem muitas responsabilidades." Eleanor considera que Samantha não deveria ser prejudicada por um erro de Chris. Tom usa a expressão inglesa "slave driver 220 " comparando a atitude do cunhado a de um feitor de escravos.

Em Londres, no apartamento do subúrbio, Chris discute com Nola: "Como você pode ficar grávida?". Eximindo-se de culpa, ele chama o ocorrido de "má sorte inacreditável. Cristo, eu não consigo engravidar a minha mulher, não importa o quanto eu me esforce, e no instante em que você está sem proteção, eu te engravido". A norte-americana estabelece o contraponto entre a relação mecânica e entediante com Chloe ao desejo que o protagonista

\footnotetext{
${ }^{219}$ O jantar retoma o paralelo entre Um lugar ao sol e Match Point. No filme de Stevens, o sobrinho dos Eastman passa férias junto à família de sua namorada rica Angela Vickers. No entanto, o jantar à luz de velas é interrompido pela a jovem pobre Alice Tripp que está grávida de George Eastman.

${ }^{220}$ A expressão slave driver denota "alguém que faz as pessoas trabalharem muito - usada para criticar ou de forma humorística". Disponível em: 〈http://www.ldoceonline.com/dictionary/slave-driver>. Acesso em: 13 jan. 2010.
} 
sente por Nola: "É por que você me ama e não a ela. É uma criança concebida na paixão genuína, não parte de um projeto de fertilização”. Chris pede para que Nola faça um aborto. No entanto, diferentemente da inexperiente Alice Tripp de Um lugar ao sol, Nola adverte: "Não farei isso de novo. É a terceira vez. Eu fiz uma vez quando eu era mais nova e fiz para o Tom. Eu não queria, mas ele insistiu." Nola propõe que os dois cuidem do filho: "Você odeia o seu trabalho, odeia a sua vida. Isso parece uma benção, é um sinal.”

No apartamento de Chloe e Chris, a esposa diz que o protagonista "passou o fim de semana todo melancólico". Ele pede para conversar com ela ao passo que se dirige à janela do Parliament View. Chloe tenta consolar o marido, ela afirma que se forem problemas financeiros, "os prejuízos na bolsa, você sabe que isso não é um problema". O protagonista afirma que não pode mais continuar dependendo do pai de Chloe.

Chloe desconfia do marido: "Isso tem a ver com aquelas ligações que você andou recebendo?" Por trás da câmera, ela aproxima-se de Chris: "Você reagia de modo muito estranho após cada uma delas. Você está tendo um caso?" O protagonista repete a pergunta da esposa e nega: "Claro que não, não seja boba". A câmera aproxima-se do protagonista que afirma sentir- se culpado, "terrivelmente culpado". Chloe atribui o problema à dificuldade em engravidar: "Olha, Chris, nós dois fomos ao médico e somos absolutamente saudáveis. Eu posso conceber e você é perfeitamente capaz de fazer uma mulher engravidar. Sou eu? Eu estou obcecada e irritante em relação a isso? Eu só quero um bebê, quero ter o nosso bebê. Não tivemos sorte ainda, só isso". O protagonista beija a fronte de Chloe e abraça-a; a cena indica, portanto, o restabelecimento do casal Chloe e Chris.

Sem ter conseguido contar à esposa, Chris procura o amigo dos tempos de tenista, Henry. Os dois aparecem, na cena seguinte, sentados nos bancos do Mount Street Gardens ${ }^{221}$. Ao lado do amigo, o protagonista desabafa: "Estou pensando em deixar a minha mulher por outra. Mas quando chegou a hora de dizer isso para ela, eu não consegui”. O protagonista explica que não vê nenhum futuro com a outra mulher e que possui uma vida muito confortável com a esposa. Henry tenta argumentar que se Chris não a ama, não há o que fazer. No entanto, o protagonista interrompe o amigo: "Não disse que não a amo, só não é do jeito que eu sinto por essa outra mulher. Talvez seja a diferença entre amor e luxúria. Mas o que eu farei se deixar a Chloe? Não nego que eu me acostumei a um certo estilo de vida. Devo

\footnotetext{
221 “O Mount Street Gardens foi construído em 1889 no local de um cemitério que pertencia à igreja St. George na Hanover Square. No parque existem noventa bancos patrocinados". Disponível em: <http://www.filmlondon.org.uk/content.asp?CategoryID=972>. Acesso em: 13 jan.2010.
} 
desistir de tudo? Pelo quê?". Henry retoma a justificativa do amor, mas o protagonista continua: "Para viver como? Onde? Trabalhar em que?" Henry argumenta: "Para mim parece que você é muito bom no que faz. Deve haver outro emprego em outra firma." Diferentemente do amigo de Chris, o espectador sabe da inabilidade do protagonista com as finanças. O executivo precisa recorrer constantemente ao sogro para cobrir seus erros. Chris retoma as relações de favor envolvidas no jogo: "A verdade é que eu sou o genro do patrão. E ele me adora." Diante da afirmação de Chris, Henry encerra a conversa: "A meu ver, não parece que você quer essa outra mulher suficientemente para desistir de tudo o que você conquistou". A conversa entre Chris e Henry em um parque ao ar livre na cidade funciona como uma espécie de consciência para o protagonista, apresentando uma alternativa para o ambiente de tédio e claustrofobia ao lado dos Hewett no Swiss Re e no Parliament View.

O diálogo entre o protagonista e seu amigo é precedido pela reconciliação entre Chris e sua esposa e seguido por uma discussão com Nola. O protagonista retorna ao bar onde sugerira a Nola anteriormente que poderia "talvez" deixar a esposa. Dessa vez, Chris diz que contará a Chloe, "após a viagem [com os amigos dos Hewett pelas ilhas gregas]". Nola, todavia, pede para que ele pare de enganá-la: "Por que você não conta agora? Achei que queria parar de viver essa mentira". Chris argumenta que "Não é fácil". Nola percebe a desfaçatez do protagonista: "Como você pode sair de férias com uma mulher que você sabe que vai largar assim que voltar? Sabe como eu me sinto? Sinto ciúmes. Não gosto da ideia de você fazer amor com ela. Não gosto da ideia de que você vá passear pelas ilhas com ela, é romântico!"

Na cena seguinte, o mundo das artes, dos negócios e das relações pessoais volta a relacionar-se. O protagonista caminha em direção à câmera. Ao fundo podem-se observar duas telas grandes: as pinturas são retratos de uma mulher ${ }^{222}$. As cores vivas que compõem o fundo da tela sobressaem-se em relação ao corpo distorcido e lânguido (Figura 7). Em um depósito da galeria, Chris encontra Chloe. A jovem herdeira avisa ao marido que a viagem às ilhas gregas foi cancelada. No local em que a galerista Chloe toma notas, outros quadros podem ser observados como uma paisagem da cidade de Londres em tons pastéis e um outro autorretrato da artista ao fundo do depósito (Figura 8).

\footnotetext{
${ }^{222}$ Nos créditos do filme, encontra-se a informação de que as telas, expostas na galeria de Chloe, pertencem à artista britânica Lucy Jones. Jones é conhecida por suas "séries de auto-retratos e pelo uso de cores vívidas e não-naturais". Disponível em: <www.momentumpublishing.co.uk/web_jones.jpg>. Acesso em: 1 mar. 2010.
} 
$\mathrm{Na}$ galeria de Chloe, o passeio pela Tate é retomado. As pinturas figurativas selecionadas por Chloe diferem da arte abstrata à qual a herdeira e sua colega manifestaram aversão. $\mathrm{O}$ gosto das jovens coincide com as escolhas das corporações britânicas, conforme explica Chin-tao Wu: “As companhias britânicas tendem a comprar obras figurativas. Entre as pessoas que não têm o que Pierre Bourdieu chama de "código" para decifrar as manchas de cores e linhas, prevalece um profundo sentimento de desconforto e às vezes até de ameaça, associado à abstração",223.

Os quadros expostos na galeria de Chloe reproduzem figuras humanas e podem ser considerados como representantes da arte contemporânea inglesa figurativa. A pesquisadora taiwanesa explica o motivo para o investimento corporativo em arte contemporânea: "Esta última tem um apelo inegável na medida em que dá acesso ao culto elegante da personalidade artística, bem como permite a uma companhia projetar para si mesma uma imagem progressista e inovadora" 224 . A ideia de Chloe comandar uma galeria agrada ao patriarca e contribui para a imagem da Hewett Inco., associando-a ao mundo das artes. Na cena da galeria de Chloe, a herdeira sugere ao marido que eles caminhem até a ópera, o que indica que o Royal Opera House, instituição que recebe patrocínio da família Hewett, localiza-se próximo à galeria. De acordo com a pesquisa sobre a intervenção corporativa nas artes, os homens de negócios ingleses privilegiam o patrocínio corporativo à música clássica e à ópera. Em terceiro lugar, aparecem os museus ${ }^{225}$. Assim, a galeria de arte e o patrocínio à ópera são duas instâncias ligadas ao status da família e aos negócios da empresa.

O protagonista retorna à sala de exposição da galeria. No canto direito da tela há outro autorretrato de Lucy Jones. Os quadros da artista britânica mostram os novos investimentos de Chloe em pinturas figurativas. Quando o protagonista sai do depósito, vemos outros quadros, pinturas de figuras masculinas. No primeiro quadro, de fundo verde-claro, vê-se um homem branco de feições claras e vestimenta cinza com o rosto virado para cima. Na mesma tela, observa-se o contorno da figura masculina preenchido com um azul vivo. Chris olha para baixo e telefona para Nola, sem olhar para os quadros. Enquanto realiza a ligação, o protagonista posiciona-se entre duas telas (Figura 9).

Um rápido corte retorna ao apartamento do subúrbio londrino, no qual Nola lê um romance. Ela atende ao telefone, mas o protagonista não se identifica. Nesse ponto, a câmera

\footnotetext{
${ }^{223}$ Chin-tao Wu, op.cit., p.288.

${ }^{224}$ Ibid., p. 278.

${ }^{225}$ Chin-tao Wu, op.cit., p.154.
} 
aproxima-se de Chris, o terno preto e a gravata cinza escuro do executivo contrastam com as cores vivas das pinturas ao fundo. Nesse ponto, o enquadramento seleciona partes dos quadros, vemos apenas a sombra azul e parte do macacão branco com fundo ocre. $\mathrm{O}$ executivo desliga o telefone. A câmera volta para o apartamento de Nola, onde a norteamericana tenta identificar a chamada. Chris olha para o chão, enquanto guarda o telefone. No canto direito da tela, pode-se observar a penumbra humana preenchida em azul. Suas mãos estão manchadas, a tinta escorre da tela. Há uma atmosfera de melancolia, solidão e degradação nas formas humanas representadas por Jones. Apesar de figurarem como investimentos da herdeira, o enquadramento, feito pelo filme, localiza nos detalhes das pinturas o sujeito reduzido a um fragmento do macacão de trabalho ou a uma sombra azul, cujas mãos estão manchadas.

Da galeria de arte de Chloe, Allen corta para o camarote dos Hewett no Royal Opera House, o que reforça novamente o caráter do investimento corporativo nas artes. Diferentemente das outras cenas no Opera House, desta vez, a câmera não se aproxima dos personagens, mas posiciona-se com certo distanciamento em um plano geral, onde se pode observar tanto a família Hewett reunida (Eleanor e Alec; Tom e Heather; Chris e Chloe) quanto os outros camarotes ao lado. Sem mostrar o palco, apenas o camarote, a cena indica o privilégio de classe, o ambiente reservado dos camarotes, nos quais os integrantes não se misturam aos outros espectadores.

A utilização da música nesta breve cena do filme é diegética. A ária escolhida por Allen é "Arresta...Quali sguardi", da ópera Guillaume Tell ${ }^{226}$, de Gioachino Rossini. O espectador poderá notar o contraste entre o conflito descrito pela ópera e a ausência de combate contra as classes dominantes no filme. Tell é o legendário herói suíço que simboliza a luta pela liberdade política e individual. A ópera de Rossini, baseada no romance de Friedrich von Schiller, retrata a história da revolta dos "cantões contra o jugo austríaco"227. O momento do quarto e último ato, retratado no filme, é o da rebelião dos suíços contra o império austríaco. $\mathrm{Na}$ ópera, os insurgentes saem vitoriosos da batalha ${ }^{228}$. Dessa forma, a ópera retrata a resistência suíça e Tell seria o seu maior representante, pois ele desafia o

\footnotetext{
${ }^{226}$ Segundo Kobbé, representada integralmente, Guillaume Tell dura quase cinco horas. Ver Kobbé, op.cit., p. 258 .

${ }_{227}$ Ibid, p. 257.

${ }^{228}$ Ibid, p. 257 .
} 
destino e mata o tirano, iniciando o levante: "Io non so se avrom mi gloria, / Ma la sorte io vo' tentar. / Vieni, andiam: fia l'empio estinto. ".

Diferentemente de Tell que desafia o destino, Chris joga com o acaso. No filme, o duelo não será contra o opressor, mas em detrimento de uma companheira, como se os cantões da ópera duelassem entre si e não se unissem contra o tirano austríaco. O irlandês pobre do cenário contemporâneo não matará alguém das classes dominantes do império britânico, inspirando a luta pela liberdade de seu povo, mas fará justamente o seu oposto, aliando-se à família de proprietários ingleses e eliminando sua semelhante (a norte-americana é, assim como o irlandês, o outro/a alteridade no Reino Unido).

Em certo sentido, se tomarmos a história de Chris como a de um irlandês ascendendo socialmente por meio da aliança com a aristocracia inglesa, o filme faz um comentário a respeito da ação insurgente no cenário contemporâneo, aquela que rivaliza entre si e em que o ímpeto revolucionário foi cooptado pelas elites. Em 2005, ano do lançamento de Match Point, o IRA anunciou o fim da luta armada pela unificação da Irlanda. Os norte-americanos de origem irlandesa sempre foram grandes financiadores do IRA, mas após os ataques terroristas de 11 de setembro de 2001 em Nova Iorque, a ajuda norte-americana ao IRA diminuiu consideravelmente. O senador norte-americano Ted Kennedy ${ }^{229}$ teve importância crucial nas negociações entre o Sinn Féin e o governo britânico - ao conceder o visto norte-americano para Gerry Adams entre outras ações - que culminaram no cessar fogo do IRA. Na recente eleição inglesa, o Sinn Féin declarou que quer trabalhar com os conservadores, os chamados Tories, liderados pelo primeiro-ministro britânico David Cameron: "O ex-chefe do IRA, Martin McGuinness, revelou que Cameron e a liderança dos conservadores asseguram-lhe que eles serão a favor dos acordos de paz que levaram à partilha do poder na Irlanda do Norte”,230 .

Em ensaio sobre Walter Scott e Jane Austen, Terry Eagleton aponta para o movimento que pode ser encontrado ainda em Match Point. Eagleton mostra que a "recusa à reação e à revolução, é muitas vezes elogiada como o espírito inglês do compromisso. No entanto, este 'caminho do meio', como a chamada Terceira Via na política contemporânea, não é, na realidade, nada disso. Não é um meio do caminho entre o Toryism e uma versão mais

\footnotetext{
${ }^{229}$ Disponível em: 〈http://www.guardian.co.uk/world/2009/aug/26/edward-kennedy-northern-ireland>. Acesso em 13 jan. 2010.

${ }_{230}$ Disponível em: <http://www.guardian.co.uk/politics/2010/feb/17/martin-mcguinness-sinn-feinconservatives $>$. Acesso em: 20 mar.2010.
} 
esclarecida do credo. [...] Partindo de um ponto de vista radical, este compromisso forte com o capitalismo e a monarquia é apenas uma forma de ficar em cima do muro"231.

O filme mostra que o compromisso estabelecido por Chris faz-se com a elite britânica. Do templo da ópera burguesa ao apartamento pós-moderno em Londres, o protagonista permanece ao lado da família Hewett. Apadrinhado pelo sogro, o irlandês é informado sobre uma oportunidade lucrativa nos negócios. O caráter de informação privilegiada nas movimentações financeiras entre sogro (dono da empresa) e genro (empregado) é explícito:

[Alec Hewett]: "Surgiu uma oportunidade, Chris, que eu acho que será lucrativa para você. Estamos estruturando algo com uma empresa japonesa. É uma operação independente. Há uma boa soma de dinheiro que pode ser feita e acredito que qualquer um que estiver envolvido desde o início lucrará muito se as nossas previsões estiverem corretas."

[Chris Wilton]: "Parece animador".

O tipo de operação financeira oferecida a Chris pelo sogro é caracterizado como uma “oportunidade lucrativa", "algo com uma empresa japonesa”, "operação independente”, "boa soma de dinheiro", "se as nossas previsões estiverem corretas". A fala do capitalista enfatiza a condição de risco inerente à empreitada e aproxima Alec de Chris ${ }^{232}$. Lançado em 2005, o filme retrata as perdas financeiras e os cálculos errados do novato executivo combinados à "rede de proteção" do empresário transnacional que encobre os erros do genro e gerencia a especulação desmedida, característica que, como já apontamos, antecipa a crise financeira de 2008. Alec e Chris conversam em frente à vista do rio Tâmisa e do Parlamento Inglês (Figura 10). A utilização do plano-sequência nesta cena no Parliament View permite que o espectador associe a conversa privada sobre uma "oportunidade lucrativa" às decisões do Parlamento britânico, como se as ações financeiras entre sogro e genro revelassem o movimento do capital na Inglaterra.

Por sua vez, as mulheres, Chloe e Eleanor, tiram a mesa e acompanham a conversa entre o patriarca e Chris. Alec traz a matriarca à conversa: "Eleanor, acabei de contar ao Chris

\footnotetext{
${ }^{231}$ Eagleton, op.cit., p.97.

232 Nesse sentido, podemos retomar Walter Benjamin, no momento em que o autor associa as operações da Bolsa ao jogo: "todo o desenvolvimento econômico moderno tem a tendência a transformar a sociedade capitalista cada vez mais numa gigantesca casa de jogo internacional, onde os burgueses ganham e perdem capitais em consequência de acontecimentos que lhes permanecem desconhecidos. O 'inescrutável' exerce o seu domínio na sociedade burguesa como num antro de jogo... Sucessos e fracassos oriundos de causas inesperadas, geralmente desconhecidas, e aparentemente dependentes do acaso, predispõem o burguês ao estado de ânimo do jogador... O capitalista, cuja fortuna está investida em valores da Bolsa, e que ignora as causas das oscilações dos preços e dividendos, desses títulos, é um jogador profissional. O jogador, porém, é um ser altamente supersticioso.” Ver Benjamin, op.cit., p.247.
} 
as boas notícias", o que indica que o pai e a mãe de Chloe já haviam conversado sobre os problemas financeiros/conjugais do casal. Nesse momento, a câmera dirige-se à Eleanor, que está em frente às pinturas da paisagem londrina compostas por cores pastéis ${ }^{233}$ que estavam na galeria de Chloe, o que retoma a ideia de que a função das pinturas é promover o status desta família: as telas servem tanto para a galeria quanto para a decoração da residência da herdeira.

Se o patriarca encarrega-se dos problemas financeiros do genro, a matriarca, por sua vez, indica a segunda condição de permanência do protagonista na família: "O que me deixaria mais feliz não tem nada a ver com dinheiro, quero que você me torne uma avó jovem", dirigindo-se a Chris. Assim, a condição de dependência do protagonista é evidente tanto nas finanças como parte do "projeto de fertilização". Nesse longo plano- -sequência, a câmera passa por uma das pilastras do apartamento de maneira que a estrutura de concreto impede a visão do protagonista, ao passo que a matriarca discorre sobre a "função reprodutora" de Chris na família. Aliados, o patriarca e o genro riem de Eleanor, enquanto Chloe intercepta a mãe: "Você já é uma avó jovem". A matriarca conclui o argumento: "Sim, Tom e Heather estão tentando ter o segundo, mas eu quero que você seja mãe. Está bem, não me olhe desse jeito. Ficarei quieta. O que você quer de aniversário?"

Ao ouvir a discussão entre Chloe e Eleanor, Chris recorda-se do aniversário da esposa. Chloe percebe que o marido esqueceu-se da data, mas o protagonista afirma já ter comprado o presente, o que revela, aos olhos do espectador novamente, que o protagonista, apesar das evidências de que ele esquecera-se da data, acaba por convencê-la. Outro indício do disfarce de Chris é apresentado no momento seguinte quando Nola telefona para ele. O protagonista pede licença ao sogro e retira-se da sala. Chris repreende a amante: "Falei para não me ligar, eu ligo" e afirma que está na Grécia. Entretanto, a cena localiza o protagonista no andar de cima do apartamento, onde o espectador pode observar Chloe e Alec repreendendo a matriarca por ter tocado no assunto da gravidez. Nola pede para que Chris "conte tudo para a Chloe assim que chegar em casa. Eu só quero que essa situação seja resolvida. Você sente a minha falta?". Em uma mesma cena, portanto, vê-se o conflito que não se dá entre os Hewett e Chris, mas contra a alteridade representada por Nola. Pelo telefone, o protagonista despedese da norte-americana e desliga o telefone para juntar-se aos sogros e à esposa. A cena é

\footnotetext{
${ }^{233}$ As pinturas são as mesmas que estavam no depósito da galeria de Chloe. Os quadros apresentados no filme de Lucy Jones foram encomendados à artista por Allen. A pintura de Jones, Palace of Westminster, da qual provavelmente foram retiradas as telas apresentadas no filme, pode ser encontrada em cores escuras nos arquivos da artista. Disponível em: 〈http://www.art2invest.co.uk/pop-up_images/Palace_of_Westminster.htm〉. Acesso em: 12 mar. 2010.
} 
análoga ao filme de Allen, Crimes e Pecados [1989], no qual a ex-aeromoça Dolores Paley [Anjelica Huston] deixa recado com a secretária do médico Judah Rosenthal [Martin Landau], seu amante. Judah diz a mesma frase que Chris: "Por que você me ligou? Eu te disse que eu te telefono." No apartamento de Dolores, ela afirma que não conseguiu evitar, "Eu estou ficando louca. Preciso vê-lo ainda hoje. Preciso!" O paralelo entre os dois filmes será retomado no capítulo seguinte. 


\section{Capítulo III - O sujeito contemporâneo}

"Ao dramaturgo da subjetividade importa em primeiro lugar isolar e intensificar seu personagem central, que na maioria das vezes incorpora o próprio autor."

Peter Szondi, "Strindberg”, Teoria do drama moderno [1880-1950].

\subsection{Crimes e Pecados}

No terceiro capítulo, retomaremos as referências estabelecidas pelo filme às outras obras com o intuito de mapear a trajetória do protagonista de aliança com as classes dominantes. Uma das estratégias do filme de Allen é a de associar a cultura ao capital. Tênis, literatura, cinema, arquitetura e artes plásticas aparecem relacionados aos negócios de uma família. Os bens culturais são no filme entendidos como bens propriamente - investimentos -, "habilidades e destrezas" do empreendedor, o sujeito do capital. Vimos também que na própria configuração das cenas estabelece-se a comparação entre a cultura, o Estado britânico e as relações pessoais. A “oportunidade lucrativa” é oferecida pelo sogro ao protagonista em frente ao Parlamento britânico, que pode ser observado tanto pela janela do edifício residencial high tech como por meio da pintura de arte figurativa que retrata a mesma paisagem londrina. Assim como relaciona, durante a conversa entre Chloe e a amiga na Tate Modern, a gravidez da herdeira à compra das pinturas, o filme retoma a questão da concepção do herdeiro associada aos negócios, na voz de Alec e Eleanor.

$\mathrm{Na}$ cena seguinte à da conversa entre genro e sogros, novamente o filme apresenta os dilemas pessoais associados ao universo do consumo. A vitrine de uma loja de luxo aparece antes que se vejam os personagens, como se a indicação do consumo fosse anterior à ação. Pode-se observar o nome da marca Asprey ${ }^{234}$, localizada na New Bond Street. O local é o

234 “A Asprey foi fundada em 1871, em Mitcham, South London. Em 1847, a família Asprey mudou para 167 New Bond Street, local que ocupa hoje. A Asprey vende 'produtos de design exclusivo e de alta qualidade, tanto para o ornamento pessoal quanto para mobiliar com riqueza e beleza as mesas e casas das pessoas refinadas e perspicazes.' A loja estabeleceu sua reputação como a primeira fabricante de produtos de luxo, ganhando a medalha de ouro pela confecção de valises na International Exhibition, em 1862. No mesmo ano, a Royal Warrant foi concedida a Asprey pela Rainha Vitória. Durante todo o século XIX, seus negócios floresceram e outra Royal Warrant foi concedida pelo Príncipe de Gales - que mais tarde seria coroado Edward VII, ele permaneceu como um cliente importante e entusiasta da loja. O mecenato não veio apenas da família real britânica e da aristocracia, mas também da realeza estrangeira e dos nobres que visitavam a loja quando estavam em Londres. Na época do funeral de Edward VII, um membro da Asprey lembrou que 'praticamente todos os chefes de Estado estavam lá e muitos deles vieram para a Asprey. Você poderia ter visto três ou quatro deles ao mesmo tempo.' Na glamorosa década de 1920, choveram pedidos de encomenda por todo o mundo. Tais como 
mesmo em que Chris encontrou Henry, o amigo tenista. Dessa forma, percebe-se que a rua de lojas de luxo é frequentada por transeuntes como o executivo, o tenista profissional e a atriz norte-americana. A indicação da Asprey, loja que recebe encomendas dos nobres do mundo e é patrocinada e condecorada pela família real britânica, mostra que o presente para Chloe, comprado por Chris, é um produto certeiro ligado, ancestralmente, à classe dos Hewett.

Enquanto passantes caminham pela rua, vêem-se expostas na loja camisas, gravatas masculinas e porcelanas. No canto direito da tela, ao fundo, Nola aproxima-se da câmera com duas sacolas nas mãos. A cena de rua aproxima Nola e Chris dos outros transeuntes. As pessoas que caminham por esta calçada são, assim como o protagonista e a norte-americana, consumidores de alto padrão. Possuem sacolas, carregam pastas de trabalho e vestem-se como executivos. Nola para em frente à loja para observar a vitrine. Saindo da loja com uma sacola de compras na mão, vê-se o protagonista. O carro da empresa Hewett, utilizado por Chris, está em frente ao local. A câmera corta para Nola que surpreende o protagonista através de uma das vitrines da loja. Desse modo, a imagem de Chris é vista sob o ponto de vista de Nola por intermédio de uma vitrine, ressaltando assim a questão do consumo, associando o executivo à mercadoria exposta na galeria.

Após surpreendê-lo saindo da Asprey, Nola telefona para Chris. O protagonista afirma que está na Sardenha e que voltará à Londres em cinco ou seis dias. Novamente, o olhar da câmera expõe a mentira, apresentando um novo local, relacionado - por intermédio das pessoas que o frequentam - à loja de alto luxo. Chris, Chloe, Tom, Carol e outros amigos dos Hewett estão na capital inglesa em um restaurante suntuoso, iluminado à luz de velas. A câmera volta para o apartamento dos subúrbios onde está Nola. A iluminação dos espaços é bastante escura, tanto no restaurante onde estão os irmãos Hewett e Chris quanto no apartamento de Nola.

Em contraposição à residência de Nola observa-se, em seguida, o protagonista sair de um edifício cuja fachada assemelha-se a de um prédio de negócios como o Swiss Re. Todavia, trata-se da entrada do apartamento de Chloe e Chris. Nesse ponto, podemos retomar a questão da arquitetura contemporânea na era financeira que constrói logotectures homogeneizando o

os do milionário americano, J.P. Morgan. A coroação de Elizabeth II, em 1953, originou a Asprey Coronation Year Gold Collection que se destacava por trazer uma sobremesa de ouro 18 quilates, serviço de café e licor, chegando a pesar quase 27 quilos. Essa coleção notável passou a ser exibida na loja Bond Street, em abril de 1953 e, posteriormente, excursionou pelos Estados Unidos. Hoje, [...] ela continua a celebrar o melhor em ourivesaria, design e materiais para oferecer aos seus clientes objetos que são como tesouros. [...]". Disponível em: 〈http://www.asprey.com/heritage/>. Acesso em: 13 mar. 2010. 
espaço da residência e do trabalho. O revestimento espelhado e a entrada do Swiss $R e$ e do Parliament View apresentados no filme fazem com que os dois edifícios aparentem ser o mesmo local. Ao sair da recepção de sua residência, Chris cumprimenta o seu motorista, John, que pede licença para buscar o carro. Enquanto Nola aproxima-se do local, pode-se observar o motorista ainda próximo a Chris. O protagonista é surpreendido pela amante que ameaça contar a Chloe. Nola grita em frente à residência do executivo: "Você é um mentiroso! Mentiroso!", ao passo que Chris tenta evitar que ela fale alto. Ao fundo, o espectador pode ler a inscrição precisa do local: "Parliament View Apartments". O protagonista chama um táxi e retira Nola da entrada de sua residência. É interessante notar como a boa aparência do executivo evita que qualquer transeunte, os funcionários ou seguranças do prédio, ou o próprio motorista de Chris tentem impedir a discussão entre o casal. Nola é colocada à força no táxi pelo protagonista.

No apartamento do subúrbio, observa-se a discussão entre Chris e Nola. Allen mostra a briga do casal em dois momentos; o primeiro quando Chris tenta convencer a amante a realizar um aborto; e o segundo, quando ele já planejou o assassinato de Nola. Nas duas cenas, observa-se a repetição dos argumentos do protagonista. Nas discussões entre Nola e Chris, a referência ao filme Crimes e Pecados [1989] é retomada. Durante a discussão, Nola desconfia do protagonista: "Você está me deixando louca, eu não sei se acredito em você ou não.” Ela expõe a mentira de Chris:

[Chris Wilton]: "Estava tudo pronto para eu falar com ela e aí você ligou e eu me senti culpado por ter dito a você que eu ainda estava na Grécia."

[Nola Rice]: "Você disse Sardenha."

[Chris Wilton]: "Eu falava rápido. Eu não... Não queria que ela soubesse do que eu estava falando."

[Nola Rice]: "Uma hora ela vai saber."

[Chris Wilton]: "Não posso dizer a ela."

[Nola Rice]: "Então, eu direi."

[Chris Wilton]: "Nola, pare!"

[Nola Rice]: "Isto é loucura, nós vamos ter um filho juntos!"

[Chris Wilton]: "A gente não precisa ter um filho juntos. A vida seria bem mais simples se não tivéssemos."

[Nola Rice]: "Simplificaria as coisas para você, mas não para mim."

A utilização do campo/contra-campo é feita de maneira que quando ouvimos Chris observamos Nola e vice-versa. Ao pedir para que a amante acredite nele, observamos Nola tomando alguns comprimidos, como se os remédios, assim como o vinho em outros 
momentos, fossem necessários para que ela suportasse a mentira. Ao falar do filho que Nola espera, o pai oferece dinheiro:

[Chris Wilton]: "Pensei agora que mesmo que caso você tenha o filho, eu posso lhe ajudar financeiramente."

[Nola Rice]: "Isso não é o bastante."

[Chris Wilton]: "Nola, seja razoável ${ }^{235}$."

[Nola Rice]: "Isso é exatamente o que Tom disse quando rompeu com o nosso noivado. Ser razoável me deixou onde eu estou agora".

[Chris Wilton]: "Então, você está me ameaçando? Se eu não fizer o que você quer, você vai procurar a minha esposa."

[Nola Rice]: "Você mentiu para mim? Todas aquelas vezes que nós fizemos amor, todas aquelas conversas, você estava mentindo?"

[Chris Wilton]: "Claro que não menti."

[Nola Rice]: "Conte para a Chloe. Alguém precisa explicar a situação, ou você faz isso, ou eu faço."

[Chris Wilton]: "Ok. Eu farei a coisa certa."

Nola compara o discurso de Chris - associado ao dinheiro - ao de Tom Hewett. Nesse ponto, os amantes rivalizam entre si, ameaçando um ao outro. No momento em que Nola diz ao protagonista que ele mente para ela, apenas parte do corpo de Chris é mostrada, retomando a ideia, apresentada pelos quadros na galeria de Chloe, de que o protagonista fica reduzido ao uniforme de executivo. Chris ajoelha-se ao lado de Nola e promete que fará "a coisa certa". Nola toma outro comprimido.

Entre o quarto de Nola no subúrbio e o de Chris no Parliament View, a ópera "O Elixir de Amor" volta à cena para caracterizar os pensamentos de Chris. Se por um lado, a ópera retoma a história do falso elixir, por outro, ela indica o sofrimento pela amada: "Un solo istante i palpiti / del suo bel cor sentir!..." Embora a música extra-diegética possa romantizar os pensamentos do protagonista, o olhar da câmera não permite que esqueçamos que se trata da permanência do protagonista ao lado de Chloe como membro da família rica. A câmera focaliza a herdeira que está dormindo. A cena noturna no apartamento de Chloe e Chris pode ser interpretada também como o momento do planejamento do crime.

A ideia do crime é recuperada pela cena seguinte na casa de campo. A ópera é cortada de forma ríspida enquanto se observa o exterior do Englefield Estate. Da indicação da

\footnotetext{
${ }^{235}$ Em inglês, utiliza-se "reasonable". O adjetivo é utilizado tanto para caracterizar uma pessoa sensata, racional como aquele que tem boas razões, que é razoável, sem ser muito extremo ou excessivo. Todavia, o adjetivo também pode ser usado no sentido propriamente econômico do termo: "a reasonable price", como sinônimo de "cheap" (barato). Disponível em: <http://www.merriam-webster.com/dictionary/reasonable>. Acesso em: 13 mar. 2010.
} 
propriedade, a câmera insere-se em um local escuro, recuperando o aspecto sombrio apresentado nas cenas anteriores. A porta é aberta pelo protagonista e pode-se identificar o cômodo da propriedade: o porão onde a família guarda as armas. O espectador recordará que este é o local onde Alec e Tom ofereceram uma espingarda de caça para Chris, após o patriarca indicar o curso de administração. Na segunda vez em que o local aparece, o protagonista pegará a arma da família. O momento não será de insurgência contra o opressor, em oposição ao ambiente sufocante no trabalho e no casamento, mas para eliminar Nola. Diferentemente do patriarca que monta a arma com a habilidade de um atirador profissional, Chris prende o dedo na porta, atrapalha-se com a espingarda e derruba as balas.

Na biblioteca da casa de campo, Chloe pergunta pelo marido a Tom e Heather. O casal lê revistas. No porão, o protagonista ouve a voz da esposa e tenta apressar-se. Chloe é chamada pela mãe para que a ajude na escolha de um vestido. No corredor, entre a escadaria da casa de campo e o porão, observa-se uma pintura a óleo de um dos ancestrais da família Hewett, um patriarca. A banalidade das revistas e da escolha do vestido contrasta com o que ocorre no porão da casa de campo, onde Chris pega a arma de caça da família, escondendo-a na mochila para raquetes de tênis.

Após a cena na casa de campo onde o protagonista pega a arma do sogro, ele retorna à cidade, para o apartamento de Nola. O assassinato dar-se-á no intuito de preservar a aliança entre Chris e a família Hewett. No apartamento do subúrbio, a cena é paralela às outras discussões entre Nola e Chris. O protagonista reitera a promessa e acusa Nola de querer vingar-se dos Hewett:

[Chris Wilton]: "Contarei para a Chloe amanhã."

[Nola Rice]: "Você diz isso todo dia e sempre recua. Eu voltei à estaca zero. Quero que algo seja feito, Chris. Se você não tem coragem de fazer, eu farei."

[Chris Wilton]: "Isso seria a sua vingança contra a família Hewett inteira, certo?"

[Nola Rice]: "O que diabos isso quer dizer? A minha teoria é que você quer que eu conte para a Chloe para que você não tenha que fazer isso."

A câmera acompanha Nola, sob o olhar do protagonista. Chris pode ser visto pelo reflexo do espelho, ao lado de Nola: "Bem que eu gostaria de ter alguém em quem eu pudesse confiar, mas é tudo tão secreto. Preste atenção, Chris, se eu não fizer alguma coisa sobre isso, nós vamos nos separar. Eu vou ter o seu bebê!" O olhar da câmera se mantém em Nola e tem- 
se acesso à imagem do protagonista apenas por meio do reflexo do espelho, o que ressalta a ideia do discurso de Chris como disfarce, dissimilação.

[Chris Wilton]: "Eu contarei para ela amanhã, Nola. O que mais você quer que eu faça?"

[Nola Rice]: "Outra vez? Conte para ela agora! Esta noite!"

[Chris Wilton]: "Não posso, não antes de ela dormir. Não seria a hora certa. Nola, amanhã está bom. A que horas você volta do trabalho?"

[Nola Rice]: "No horário de sempre, às $18 \mathrm{~h} 30 . "$

[Chris Wilton]: "Estará em casa às 18h45?"

[Nola Rice]: "Claro. Chris, você me faz dizer essas coisas, eu me odeio por isso. Eu só quero que a gente fique junto."

[Chris Wilton]: "Nós ficaremos."

Nola sai de cena, ouve-se o barulho dos remédios que ela toma. No entanto, o olhar da câmera continua no espelho, refletindo a imagem de Chris como uma mancha, um borrão, semelhante às pinturas da galeria de Chloe. Enquanto o protagonista confirma o horário que Nola sai do trabalho, observa-se apenas Chris refletido no espelho, ao passo que Nola está fora do quadro. Diferentemente dos espectadores, ela não sabe que o protagonista marca o encontro para eliminá-la. Nola retorna à frente do espelho e pede ao amante que "fiquem juntos". A reiteração da promessa feita pelo protagonista - através do espelho - mostra-se como falsa impressão, aos olhos do espectador.

As sequências de discussões entre Nola e Chris lembram a briga entre Dolores [Anjelica Huston] e Judah [Martin Landau], no filme Crimes e Pecados (1989). No apartamento de Dolores, a amante recorda uma das viagens do casal, onde o médico explica para ela a diferença entre os compositores Schuman e Schubert. Em um flashback, observa-se o casal correndo pela praia enquanto Judah explica a Dolores que o primeiro compositor é "muito sentimental, cheio de floreios", ao passo que o segundo, preferido pelo médico, é triste e faz lembrá-lo de Dolores. As recordações de Dolores são interrompidas pela chegada de Judah ao apartamento da amante. Os dois discutem e Judah apresenta o mesmo argumento que Chris: "Você está sendo muito pouco realista, sabe?" Assim como o executivo de Match Point, o médico oftalmologista de Crimes e Pecados oferece a amante uma compensação financeira: "Estive pensando e me ocorreu que se eu tiver feito você perder boas oportunidades que poderiam ter sido lucrativas para você, eu estarei à disposição para reembolsar-lhe.” Dolores recusa o dinheiro e afirma que quer contar à Miriam [Claire Bloom], a esposa de Judah. A discussão entre os amantes no apartamento de Dolores retoma a cena de abertura de Crimes e Pecados, na qual o médico conceituado recebe uma homenagem por 
suas ações beneméritas. Em oposição aos personagens que participaram da comemoração, Dolores conhece os crimes financeiros praticados por Judah:

[Dolores Paley]: "Eu quero que ela saiba a verdade, ela precisa saber que o marido dela é um mentiroso e estelionatário"

[Judah Rosenthal]: "Não ouse me chamar de estelionatário."

[Dolores Paley]: "Não sou cega. Sei o que se passou entre a sua filantropia e as suas ações."

[Judah Rosenthal]: "Não peguei nada, nem um tostão. Minha consciência está limpa."

[Dolores Paley]: "Você precisou de dinheiro para cobrir suas perdas, eu estava por perto quando isso aconteceu."

[Judah Rosenthal]: "Ok. Eu precisei de uma ajuda temporária. Quer dizer, por Deus, depois de uma vida inteira de esforço e trabalho, um homem não vai se deixar falir, vai? Afinal, girar capital não é roubar."

[Dolores Paley]: "Sem perguntar ou dizer nada a alguém?" juros."

[Judah Rosenthal]: "Escute aqui: cada centavo foi devolvido com

[Dolores Paley]: "Não acho que eles veriam dessa forma."

[Judah Rosenthal]: "É isto que pretende fazer? Prender-me com ameaças? Ameaças estúpidas e calúnias? É este o seu conceito de amor?"

[Dolores Paley]: "Não vou ser chutada! Quero falar com a Miriam!"

[Judah Rosenthal]: "Pelo amor de Deus, pense no que você está fazendo comigo! Por favor!"

[Dolores Paley]: "Não me peça para entender, eu preciso de você."

Dolores, portanto, ameaça denunciar não apenas o romance como também as ações fraudulentas do médico. Em Crimes e Pecados, após a discussão entre a amante e Judah, seguem-se as histórias dos outros personagens, os "pequenos delitos". Por sua vez, em Match Point, o embate entre Nola e Chris é o tema central do filme. Diferentemente do protagonista de Match Point, Judah contrata seu irmão Jack [Jerry Orbach] para resolver o problema com Dolores. Durante a conversa, os irmãos passam pela piscina da residência de Judah, que aparece coberta por conta do inverno. Eles entram em uma das salas da casa, onde se vê o quadro A Bigger Splash (1961), do pintor britânico David Hockney ${ }^{236}$. Na pintura, observa-se

\footnotetext{
236 "Nascido em 1937, em Bradford, na Inglaterra, o pintor, gravador, fotógrafo e cenógrafo inglês, David Hockney é talvez o mais popular e versátil artista britânico do século XX. O desenvolvimento de Hockney foi uma continuação de seus trabalhos como estudante na Bradford School of Art, embora tenha ocorrido uma mudança de temática significativa após sua mudança para a Califórnia, no final de 1963. É evidente que quando ele mudou para Los Angeles, a cidade estava, ao menos em parte, em busca da fantasia que ele tinha concebido como vida sensual e desinibida dos jovens atléticos, das piscinas, palmeiras e do sol perpétuo. Em sua chegada na Califórnia, Hockney trocou a pintura a óleo por tintas acrílicas, aplicando-as sob uma camada leve, de cor lisa e brilhante, que ajudou a enfatizar a preeminência da imagem. As ansiedades de Hockney sobre o surgimento do moderno tinham diminuído na medida em que foi capaz de aparar os dispositivos e permitir que a sua representação naturalista do mundo falasse por si." Disponível em: $<$ http://www.tate.org.uk/servlet/ArtistWorks?cgroupid=999999961\&artistid=1293\&page=1\&sole=y\& collab=y\& attr=y\&sort=default\&tabview=bio $>$. Acesso em: 13 mar.2010.
} 
o mergulho de um homem em uma piscina de uma casa da classe alta na Califórnia. Após passarem pela piscina, os irmãos entram na sala de ginástica onde acertam o assassinato de Dolores:

[Judah Rosenthal]: "Esta mulher vai destruir tudo o que construí."

[Jack Rosenthal]: "Isto é o que estou dizendo, se essa mulher não quer ser razoável, dê o próximo passo."

A indicação de que a amante não quer ser "razoável" aproxima o protagonista de Match Point dos irmãos Judah e Jack de Crimes e Pecados. Assim como Dolores, Nola pode destruir "tudo o que Chris construiu". Ao cometer o crime com as próprias mãos, o protagonista de Match Point une características do oftalmologista e de seu irmão. No filme de 1989, há espaço para a "fagulha de religião"237 representada pelo rabino Ben [Sam Waterston]. Por sua vez, no filme de 2005, Chris descreve as atividades religiosas do pai, que era pastor, como uma espécie de "fanatismo desprovido de sentido".

Nesse ponto, retomaremos a análise pormenorizada de Match Point para mostrar que os "pequenos delitos", apresentados em Crimes e Pecados, associam-se diretamente ao conflito central. Do apartamento de Nola no subúrbio, Allen retorna ao Parliament View em frente ao rio Tâmisa. Observa-se a cozinha da residência do casal Hewett Wilton às escuras. O protagonista caminha em direção à câmera e acende as luzes do apartamento, enquanto a esposa afirma que "ele estava muito nervoso durante a apresentação de balé." Chris atribui à indisposição a "baixa taxa de açúcar, daqui a pouco melhoro." Aos olhos do espectador, a referência ao mal-estar do protagonista retoma a falta de autonomia de Chris perante a herdeira e retoma a discussão com Nola. Por sua vez, Chloe relembra o projeto de fertilização, a relação sexual monitorada pelos médicos: "Eu ainda não posso ficar com você esta noite, não terminei a minha pequena dose de não sei o quê"”.

Chris afasta-se da esposa, ela vasculha a mochila de tênis do marido e pergunta se a faxineira colocou uma de suas camisetas de tênis na mochila de Chris. Se por um lado, a cena quase coloca em flagrante o roubo da arma, por outro revela o controle da esposa que vasculha os pertences de Chris. Outro aspecto presente na cena é a habilidade do protagonista em persuadir a herdeira: "O que você está fazendo? Deixa que eu olho. Eu tenho tudo organizado aí." Chloe culpa a empregada pelo delito: "Tudo bem, eu não queria mexer em nada. Eu não sei em qual outro lugar isso pode estar." $\mathrm{Na}$ reclamação da jovem herdeira,

${ }^{237}$ Lax, op.cit., p.369. 
disparada contra a empregada, Chloe usa a expressão "bloody"238: "Ela está sempre misturando as minhas coisas com as suas. Está vendo, eu sabia. Ela sempre faz isso. Eu vou ter que falar com ela sobre isso. É realmente..."239. A expressão "bloody", que marca ênfase, traz consigo certo tom de grosseria da jovem Hewett para com os empregados. Aos olhos do espectador, a expressão britânica, que também denota um sangramento, ou uma "situação com muitos mortos e feridos" 240 e que no filme é utilizada pela herdeira Hewett no momento que antecipa o assassinato pode relacionar-se com a arma de caça da família escondida dentro da insuspeita mochila para raquetes de tênis do irlandês. Assim como a irmã, Tom também usa o adjetivo "bloody" para caracterizar a temporada de caça ao galo silvestre, o que retoma a cena do tiro no campo e o acordo no porão em que Alec e Tom oferecem a espingarda ao protagonista.

Ao retirar as camisetas de Chloe, Chris derruba uma das balas da espingarda. A herdeira percebe que o marido esconde algum objeto em seu bolso, todavia, ele arranja uma desculpa: "É a minha caixa de remédios". (Apesar de se tratar de uma desculpa, os medicamentos são aqui novamente utilizados pelos personagens para suportar a opressão). Chloe, que controla a alimentação, as roupas, o trabalho e os remédios do marido, quer saber quais remédios Chris utiliza. O protagonista distrai a esposa: "É para o stress, você me estressa tanto." O casal se beija e ri, ele conta que comprou ingressos para o teatro, ela fica surpresa com a atitude do marido: "Isso não é do seu feitio. Eu pensei que você odiasse musicais."

\footnotetext{
${ }^{238}$ Característica do inglês britânico, o adjetivo "bloody" é utilizado para "enfatizar o que você está dizendo de uma forma sutilmente rude." Pode ser também usado para caracterizar algo que esteja "coberto de sangue, ou um sangramento"; "uma situação com muitos mortos e feridos". Como verbo, nas formas "bloodied", "bloodies" ou "bloodying", pode ainda caracterizar "o ato de ferir alguém, ocasionando a saída de sangue, ou cobrir algo com sangue". Disponível em: $<$ http://www.ldoceonline.com/dictionary/bloody $>$. Acesso em 13 jan.2010.

239 "She's always bloody mixing my stuff in with yours. See, I knew it! She always bloody does that. I've got to have words with her about it. It's really..."

${ }^{240}$ A expressão "bloody" ficou mundialmente conhecida pelo evento "Bloody Sunday", ocorrido em 1972, no qual catorze irlandeses foram mortos a tiros por policiais britânicos quando protestavam pacificamente na cidade de Derry, na Irlanda do Norte. Disponível em: <http://www.guardian.co.uk/uk/2010/jun/15/bloody-sundayreport-soldiers-prosecuted>. Acesso em: 16 jun.2010. No verbete do dicionário Longman Online também encontramos a referência ao "Bloody Sunday": "no domingo, 30 de janeiro de 1972, quando soldados britânicos na Irlanda do Norte usaram da força para controlar uma grande multidão que protestava contra a política do "internment" (colocar pessoas na prisão sem julgamento, se elas fossem suspeitas de serem membros do IRA). Treze pessoas foram mortas quando os soldados atiraram contra a multidão". Disponível em: <http://www.ldoceonline.com/dictionary/Bloody-Sunday >. Acesso em: 16 jun. 2010.
} 
A referência ao musical The Woman in White ${ }^{241}$ figura na cena como uma espécie de elixir para Chloe - enquanto o marido comete o assassinato, ela distrai-se no musical - como também mapeia a distinção de classe, os locais frequentados pelo casal Hewett Wilton, e apresenta Nola como um fantasma. Chris usa o musical como álibi para o crime. No entanto, o próprio The Woman in White ${ }^{242}$ reitera a ideia da mulher como um fantasma que ronda a cena. No filme de Allen, o musical é mais uma evidência do interesse da família Hewett pelo showbusiness. É necessário lembrar ainda que as apresentações de óperas clássicas que a família assiste no Royal Opera House apresentam revestimento contemporâneo. As montagens contemporâneas no Royal Opera House são, assim como os musicais, paramentadas com efeitos visuais e fazem parte do circuito do showbusiness na cidade.

A câmera retorna para uma loja de roupas, mas não se trata do executivo saindo da Asprey. Desta vez, por trás da vitrine, o espectador observa o interior da pequena loja Paul and Joe, onde Nola trabalha como vendedora. No local, repleto de roupas, ela atende ao telefone. Chris avisa a Nola para que "quando sair do trabalho vá direto para casa, tenho boas notícias." O uso do termo "boas notícias" retoma o acordo financeiro entre Alec e Chris no

\footnotetext{
${ }^{241}$ A música de The Woman in White, utilizada por Allen, é a de Frank Lloyd Webber, autor das canções de Cats e The Phantom of the Opera, entre outros. O musical esteve em cartaz na capital inglesa, em 2004, no Palace Theatre. Lloyd foi considerado pelo crítico Ben Brantley como "um mestre em lavagem cerebral e em The Woman in White ele conseguiu chegar ao extremo, com motivos reiterados insistentemente que agem nos ouvintes como ferros de marcar. Esses sons são conseguidos por uma longa marcha de recitativo que explica e re-explica o enredo elaborado em uma composição musical extremamente desajeitada". Disponível em: <http://theater.nytimes.com/2005/11/18/theater/reviews/18woma.html>. Acesso em: 16 jun. 2010.

${ }^{242}$ A história de The Woman in White pode ser resumida como "um romance epistolar, escrito pelo escritor inglês Wilkie Collins, em 1859. O protagonista Walter Hartright é um jovem professor de desenho. Hartright conhece uma mulher misteriosa vestida de branco, aparentemente perturbada. Ele a ajuda a chegar em casa, mas descobre que ela escapara de um hospício. Em Limmeridge House, Hartright conhece a jovem Laura Fairlie, sobrinha do senhor Frederick Fairlie, e Marian Halcombe, sua dedicada meia-irmã. O jovem professor de desenho acha que Laura é muito parecida com a mulher de branco, chamada Anne Catherick. A simplória Anne viveu por um tempo em Cumberland quando era criança e cuidou da mãe de Laura, que foi a primeira a vesti-la de branco. Hartright e Laura se apaixonam. Mas Laura foi prometida para casar com o Sir Percival Glyde. Marian pede para que o jovem professor de desenho saia de Limmeridge. Anne Catherick, após mandar uma carta para Laura alertando-a sobre Glyde, encontra Hartright que está convencido de que Glyde foi o responsável por trancar Anne no hospício. No entanto, Laura e Glyde acabam se casando. Após diversas peripécias, Marian cai doente com tifo. Laura viaja para Londres e troca de identidade com Anne. Anne acaba morrendo do coração e é enterrada como se fosse Laura, por sua vez, a segunda foi dopada e colocada no hospício como se fosse Anne. Quando Marian melhora e visita o hospício em busca de Anne, ela acaba encontrando Laura que está supostamente louca por achar que é Lady Glyde. Marian suborna o atendente do hospício e Laura escapa. Hartright retorna a salvo e os três vivem juntos em situação de pobreza e reclusão. Hartright está determinado em recuperar a identidade de Laura. Ele acaba descobrindo o segredo de Glyde. Há muitos anos atrás, Glyde falsificara o registro de casamento. Glyde tenta recuperar o registro, mas acaba morrendo em um incêndio na igreja. Hartright descobre que Anne é a filha ilegítima do pai de Laura, o que explica a semelhança entre as duas. A identidade de Laura é recuperada e Hartright e Laura se casam. Com a morte de Frederick Fairlie, o filho de Hartright e Laura se torna o herdeiro de Limmeridge". Disponível em: <http://www.wilkiecollins.info/books_woman_white.htm\#Plot>. Acesso em: 16 jun. 2010.
} 
Parliament View e antecipa a forma como o assassinato de Nola será narrado pela família por meio de uma notícia de jornal. O protagonista atravessa a rua entre blocos de prédios, ao passo que convence Nola: "Cuidei de tudo, mas não quero falar por telefone. Você tem que me encontrar logo após o trabalho. Nós temos planos para fazer." Nesse momento, Chris para em frente ao Swiss Re e observa a fachada do prédio de negócios. O revestimento espelhado do prédio, bem como a construção em formato de ogiva, destaca a logotecture entre os blocos de prédios financeiros. (Figura 11)

A câmera retorna para a loja, onde Nola está feliz com a "boa notícia". A atriz cancelará o encontro com seu agente para encontrar o protagonista. A colega de trabalho de Nola pergunta se foi "ele" quem ligou; o que demonstra que a jovem norte-americana pode ter contado a alguém sobre o relacionamento com o executivo. Entre a ligação de Chris e o assassinato de Nola, Allen inclui o motivo do anúncio das "boas notícias" feito por Alec no Parliament View, a saber, a "oportunidade lucrativa” com a empresa japonesa.

Por intermédio das treliças, das janelas do escritório, compostos por estruturas metálicas e vidros que revestem o Swiss Re, Allen apresenta o "fechamento do negócio promissor". Sem que se possa ver nitidamente os personagens, ouve-se a voz dos executivos Rod Carver e Chris que fecham o acordo (anteriormente arranjado por Alec, o dono da empresa). Rod alerta aos japoneses que eles "precisam estar preparados para um fluxo de caixa nos primeiros seis meses". O funcionário de Alec inclui Chris na negociação: "Está certo, Chris? Meio ano?"

Nesse momento, a câmera passa por uma pilastra e aproxima-se do protagonista que concorda com o executivo experiente: "Meio ano é o suficiente, talvez menos." Rod encerra o encontro e despede-se dos clientes: "Vejo vocês na próxima". O ex-tenista agradece em japonês e cumprimenta curvando-se (imitando os modos japoneses) a cada um dos clientes. Rod elogia o novato: "Ótimo, sayonara com certeza. Achei que você mostrou algumas ideias interessantes para desenvolver a empresa deles." Avisado pelo sogro de que o negócio com os japoneses envolve uma boa soma de dinheiro, Chris afirma: "Estou animado com esse empreendimento de risco ${ }^{243}$ ", Rod entusiasma-se com a energia, a boa aparência e o comportamento adequado do jovem executivo, ex-tenista: "Vai jogar tênis mais tarde? Energia incrível. Adoro isso. Sinto inveja”.

\footnotetext{
${ }^{243}$ Chris usa a palavra "venture" para caracterizar o empreendimento financeiro. Em inglês "venture" pode significar também uma união entre empresas em determinado empreendimento de risco.
} 
Todavia, conforme o espectador observa, Allen posiciona em seguida ao acordo financeiro a cena do crime. De certa maneira, a montagem das cenas pode ser entendida como uma avaliação do filme sobre os empreendimentos financeiros de alto risco associando-os às ações criminosas. O espectador atento notará que o executivo Chris entra e sai do escritório high tech sem que nenhum detector de metais o previna - característica que é ressaltada se pensarmos que a construção do Swiss Re fez-se sobre as ruínas dos ataques do IRA no centro financeiro britânico.

\title{
3.2 Otelo
}

\begin{abstract}
"Com as condições de plausibilidade amontoadas sobre ele, existem duas alternativas centrais disponíveis para Otelo, e ele utiliza as duas. Uma é aparentar ser muito calmo e responsável - assim como os venezianos imaginavam que eles mesmos fossem. Mas também, e inteligentemente, ele usa a ideia racista dele mesmo como
\end{abstract} um exótico."

Alan Sinfield, "Cultural Materialism, Othello, and the Politics of Plausability".

Conforme já explicamos nos capítulos anteriores, a ópera em Match Point é utilizada como comentário às ações dos personagens, funcionando como um "colaborador ativo" 244 . No filme, após a conversa entre marido e esposa no Parliament View sobre a compra dos ingressos para o musical, Chris marca o encontro com Nola e fecha o negócio com os japoneses no Swiss Re. Na grande corporação, o executivo, Rod Carver, afirma que sente inveja do colega de trabalho, por conta de sua "energia extraordinária". Assim como Tom, que chama o protagonista de irlandês, Rod marca o caráter "extraordinário" do ex-tenista.

Nesse momento há introdução da música extra-diegética, a ópera "Otelo" 245 , de Verdi. É importante frisar que a música é inserida quando Chris ainda está no Swiss Re, no momento em que o executivo de terno e gravata e com a mochila de tênis a tiracolo sai incólume do prédio high tech. Assim observa-se que o texto, "a música e a arquitetura aparecem independentemente como arte dentro de um evento claramente demarcado"246, o do assassinato. O plano-sequência no prédio de negócios termina com a vista para a City, do ponto de vista dos executivos que trabalham no edifício.

\footnotetext{
${ }^{244}$ Brecht, 1977, p.85-86.

245 Allen utiliza a gravação da Slovak Radio Symphony Orchestra com Johannes Wildner como regente; Janez Lotric, tenor; Igor Mozorov, barítono. Conforme procuraremos demonstrar, nesta gravação encomendada por Allen existem diversas intervenções no libreto original de Verdi.

${ }^{246}$ Brecht, 2000, p.17.
} 
Por intermédio das janelas espessas entrecortadas por treliças metálicas, observa-se o centro financeiro londrino ao som da ópera de Verdi. Da grande corporação, simbolizada pelo Swiss Re, o executivo encaminha-se para o apartamento no subúrbio, o que permite relacionar o acordo financeiro na grande corporação ao assassinato.

De maneira análoga à cena anterior, na qual o protagonista dirige-se ao edifício de negócios, Chris caminha em direção à câmera. A cena retoma também as diversas ocasiões em que o executivo escapara do trabalho sufocante no Swiss Re para encontrar Nola. Desta vez, Chris olha para os lados como quem verifica que não está sendo perseguido. A câmera continua localizando a rua onde Nola mora, mostrando a tranquilidade do local. Observam-se, ao fundo, transeuntes caminhando pela calçada. Trata-se de um dia comum. O assassinato, portanto, ganha aspecto rotineiro, assim como o trabalho no Swiss Re. Por sua vez, a ópera apresenta o crime, relacionando-o a Otelo. O tenor esbraveja que Desdêmona é culpada: "Desdemona rea!”.

Dessa forma, enquanto instância separada da ação, a música extra-diegética comenta a ação do filme. A ópera aproxima o protagonista das exemplares personagens shakespereanas Otelo e Iago. De acordo com Helen Caldwell, não há nada particularmente novo "em dispor as naturezas opostas de Iago e Otelo em um único homem. O próprio Shakespeare faz isso em Conto de inverno. E muitos estudiosos vêem Iago como um símbolo do mal em Otelo e em todos os homens; outros vão mais além, a ponto de argumentar que Otelo é basicamente uma peça sobre o mistério, com Desdêmona representando Cristo, Iago, o demônio, e Otelo, o homem. Esta interpretação também se adéqua a Dom Casmurro, mas com uma nuança paradoxal, como é próprio de Machado de Assis" ${ }^{247}$. Caldwell ressalta também que Otelo trata do "conflito racista entre uma cidade poderosa e um mouro"248. Neste trabalho argumentaremos que a utilização da ópera Otelo feita por Machado de Assis no romance Dom Casmurro assemelha-se ao uso da mesma ópera em Match Point.

Nesse ponto, retomaremos a história de Otelo, a partir da análise da peça de Shakespeare feita por Alan Sinfield ${ }^{249}$. Para Sinfield, "todos os personagens em Otelo estão contando histórias, no intuito de convencer aos outros mais do que a eles próprios. [...] Há

\footnotetext{
${ }^{247}$ Ver Caldwell, Helen. Otelo brasileiro de Machado de Assis: um estudo de Dom Casmurro / Helen Caldwell; trad. Fábio Fonseca de Melo. São Paulo: Ateliê Editorial, 2008, p.155-156.

248 "Todas as óperas de Verdi se prendem a um combate político ou ideológico. [...]. Otelo não é somente um drama de ciúme, é o conflito racista entre uma cidade poderosa e um mouro, do qual depende." Ver Clément, op.cit., p.30-31.

${ }^{249}$ Sinfield, Alan. "Cultural materialism, Othello, and the politics of plausability". In: Faultlines: cultural materialism and the politics of dissent reading. Berkeley: University of California Press, 1992.
} 
uma competição de histórias, e as condições de plausibilidade são, portanto, cruciais - elas determinam quais histórias serão críveis ${ }^{\text {"250 }}$. O argumento central de Sinfield concentra-se em entender que "racismo e sexismo na peça não devem ser características apenas de Iago, ou a sua maldade arbitrária, mas a cultura Veneziana que estabelece as condições de plausibilidade" $" 251$. O próprio Otelo considera-se inferior aos venezianos, pois ele se vê como um mouro, um estrangeiro: "Otelo 'reconhece' a si mesmo como aquilo que a cultura Veneziana acreditava que ele fosse: um ignorante, um outsider bárbaro" ${ }^{252}$. Para entrar para a alta sociedade de Veneza, Otelo utiliza o exotismo a seu favor. Segundo Sinfield, quando Otelo se apresenta como um estranho, os venezianos toleram o mouro: "Até certo ponto, talvez, porque os senadores precisavam de Otelo para lutar contra os turcos, assim, eles permitem que a sua história prevaleça" 253 .

Desse modo, trata-se de um estrangeiro que luta contra outros estrangeiros. Em nome de Veneza, o mouro luta contra os turcos. No filme, a indicação da batalha travada por Otelo retoma a utilização diegética da ópera Guillaume Tell, apresentada no Royal Opera House. Diferentemente de Tell, que lidera o levante dos suíços contra o jugo austríaco, Otelo é o estrangeiro que defende aqueles que o consideram como tal, a alta sociedade veneziana. Assim, o mouro de Veneza aproxima-se ainda mais de Chris Wilton: não se trata do levante do oprimido contra o império, como na ópera de Rossini, mas da aliança entre o estrangeiro irlandês - e o império britânico.

Em Match Point, a grande corporação, simbolizada pelo Swiss Re, e o acordo financeiro que antecede o assassinato de Nola contêm reminiscências do que Eisenstein indicara para a adaptação de Uma tragédia americana, na qual a ênfase deveria recair "no trágico curso seguido por Clyde, a quem a estrutura social leva ao assassinato. ${ }^{254}$ De acordo com Eisenstein, o crime cometido por Clyde deve ser considerado como "a soma total das relações sociais, cuja influência ele sofreu em todos os estágios de desenvolvimento de sua biografia e caráter, no decorrer do filme." ${ }^{255}$ Nesse ponto, retomaremos a análise da cena do assassinato, na qual o espectador ouve a ópera Otelo enquanto o protagonista comete o crime.

\footnotetext{
${ }^{250}$ Ibid, p.29-30.

${ }^{251}$ Ibid., p.31.

${ }^{252}$ Ibid., p. 31

${ }^{253}$ Ibid, p.31.

${ }^{254}$ Eisenstein, op.cit., p.99.

${ }^{255}$ Ibid. p.98.
} 
Chris sobe as escadas do edifício de Nola. Na ópera, ouve-se a voz de Iago que trama contra Desdêmona e Otelo com "la prova del peccato d'amor". Chris ouve a voz dos vizinhos, coloca as luvas e esconde-se atrás do elevador. A música extra-diegética comenta as ações de Chris para o espectador. Otelo afirma: “Atroce idea!”, reiterando a ideia do sofrimento do protagonista e do assassinato de inocentes.

Enquanto moradores do prédio descem as escadas, o que ressalta o evento corriqueiro, banal, o assassino continua escondido atrás do elevador. Nesse ponto, a ópera seria uma espécie de aviso para o espectador, no qual Iago afirma: "Il mio velen lavora" [meu veneno está trabalhando]. O segundo ato, cena cinco, da ópera de Verdi escolhida por Allen mostra o momento em que Iago convence Otelo da traição de Desdêmona. Assim, conforme explica Sinfield, "Otelo é persuadido por Iago de sua inferioridade e da inconstância de Desdêmona e Otelo passa a agir como se isso fosse verdade" 256 .

Ao avistar a saída dos vizinhos, o executivo sobe as escadas. Ouve-se Otelo acusando Desdêmona: "Rea contro me! contro me!" Por sua vez, Iago comenta a reação de Otelo: “Soffri e ruggi!'” Otelo repete: “Atroce! Atroce!”, ao passo que no filme, o protagonista vigia pelo vão da escada a entrada e saída de moradores do prédio, enquanto dirige-se ao andar do apartamento de Nola. Nesse momento, na ópera, Iago aconselha Otelo: "Non pensateci più" [Não pense mais]. Portanto, na cena do assassinato, no plano da imagem, a serenidade do edifício e a indiferença dos vizinhos, acentuam o caráter cotidiano do evento, ao passo que a música extra-diegética retoma o crime trágico cometido pelo protagonista shakesperiano. Para Raymond Williams, o sentido trágico "é sempre cultural e historicamente condicionado"257. A tragédia encenada na ópera e no filme pode ser considerada como "a dramatização de uma desordem específica e atroz, e a sua resolução" ${ }^{258}$ que repõe a ordem estabelecida.

No momento em que Chris chega à porta da Sra. Eastby, a ópera apresenta o sofrimento do protagonista. Ouve-se Otelo e o barulho de Chris batendo à porta da Sra.Eastby. A música remete à luxúria e à suposta traição de Desdêmona. Observa-se nesse ponto a confusão inextricável dos sentimentos de Chris, suscitada pela ópera e pela imagem, uma espécie de "luta interior", próxima ao monólogo interior, descrito por Eisenstein, no qual

\footnotetext{
${ }^{256}$ Sinfield, p.31.

${ }^{257}$ Williams, Raymond. Tragédia moderna. São Paulo: Cosac Naify, 2002, p 77.

${ }^{258}$ Ibid., p.78.
} 
"a câmera tinha de ir "dentro" de Clyde. Auditiva e visualmente, era preciso mostrar a febril corrida de pensamentos intercalados com a realidade externa" 259

No filme, o protagonista bate de maneira desesperada à porta da vizinha de Nola. Pode-se observar o reflexo da Sra.Eastby aproximando-se, enquanto a ópera mostra o desespero de Otelo: "meu peito se agitava / talvez um presságio" ${ }^{\text {"260 }}$. O anúncio da angústia de Otelo é seguido pela abertura de uma fresta da porta. Ela pede para que o estranho se identifique. Nesse momento, a câmera aproxima-se do protagonista: "Eu sou o Chris, amigo da Nola, sua vizinha ao lado. Nós nos conhecemos...". A Sra. Eastby interrompe o executivo: "Desculpe-me, mas eu não deixo ninguém entrar."

Entreposto ao diálogo entre a Sra. Eastby e Chris, pode-se acompanhar as lembranças de Otelo ao lado de Desdêmona. Ele canta ao corpo, aos lábios e aos beijos da amada. Nesse ponto, o filme aproxima Desdêmona e Nola. A utilização da música extra-diegética, no momento em que Chris tenta convencer a vizinha, aponta também para o objetivo primeiro do crime, o assassinato de Nola.

O executivo prossegue em direção à Sra.Eastby: "Você não se lembra? Nós nos conhecemos, a Nola perguntou alguma coisa sobre os problemas que você estava tendo com ratos e você mencionou algo sobre manteiga de amendoim”. A menção à comida norteamericana leva a vizinha a abrir a porta para o estranho: "Ah, sim, sim." Novamente, reiterase o caráter banal e cotidiano do assassinato, por meio da menção à manteiga de amendoim. Na ópera ouve-se: "De Cassio! E agora! E agora!"261, momento que mostra o desvario e a derrota de Otelo que acredita nas acusações de Iago. A câmera muda de posição e o espectador observa Chris por intermédio do olhar da vítima, a Sra. Eastby.

Assim como Iago utiliza o lencinho de Desdêmona, Chris faz uso da manteiga de amendoim para convencer a vítima. Há na comparação um comentário irônico de Allen. Conforme argumenta Sinfield, o lencinho, ou qualquer outra acusação, já seriam suficientes para Otelo que está desde o começo convencido pela sociedade veneziana de que é "um marido inapropriado para Desdêmona [...] As histórias de Iago funcionam porque são plausíveis - para Roderigo, Brabantio, o Senado, e até mesmo para o próprio Otelo" ${ }^{\text {262 }}$. Tanto

\footnotetext{
${ }^{259}$ Eisenstein, p. 103.

${ }^{260}$ No original " $m$ 'agitava il petto / forse un presagio!"

261 "Di Cassio! Ed ora! ed ora..."

262 Sinfield, p.30-31.
} 
as ações de Chris como as da Sra.Eastby obedecem a uma determinada estrutura social que permite que altos executivos como Chris sejam insuspeitos.

O executivo entra no apartamento da vizinha e apresenta-se: "Eu sou o Chris Wilton, professor de tênis". A Sra. Eastby pergunta ao executivo o que aconteceu. O protagonista esquiva-se da pergunta e entra no apartamento: "Não há problema nenhum, Sra.. Não quero atrapalhá-la. Gostaria de saber se eu poderia checar o seu sinal de tevê. Estamos com problemas no apartamento da frente." Assim como a manteiga de amendoim, o sinal de tevê reitera o aspecto do assassinato rotineiro de pessoas comuns e associa o crime ao entretenimento. A ideia de que qualquer motivo serviria para Chris abordar a vizinha aparece cifrada na cena, na qual se evidencia de que se trata de uma desculpa improvisada, de um criminoso inexperiente. A Sra.. Eastby escuta o professor de tênis e fecha a porta de sua casa, colocando o assassino para dentro do apartamento. Na música extra-diegética, a ópera enuncia a derrota de Otelo que dá adeus à memória: "Agora e para sempre adeus santas memórias."263 A derrota do mouro comenta o diálogo entre a vizinha e o protagonista:

[Sra. Eastby]: "Com a tevê?"

[Chris Wilton]: "Estamos com uma interferência e esse é o programa favorito da Nola e eu não sei se o problema é lá em cima ou se somos nós."

[Sra. Eastby]: "Certo. Está logo ali. Preciso tomar o meu remédio."

Enquanto a Sra. Eastby vai tomar os remédios, o protagonista monta a espingarda. Nesse ponto, é retomada a ideia dos medicamentos como se fosse um elixir, uma espécie de entorpecente. Ao invés de monitorar o intruso, a vizinha sai para medicar-se. A referência à memória na ópera comenta o esquecimento da Sra. Eastby - e a aproxima de Otelo - que se recorda apenas do fato banal relacionado à manteiga de amendoim e não se lembra de que Nola apresentara Chris como senhor Harris. A ópera, portanto, comenta a cena, dando adeus ao pensamento, à razão dos personagens: "Adeus, sublimes encantos do pensamento!" ${ }^{264} \mathrm{O}$ canto de Otelo mostra a derrota do mouro como sujeito. A aproximação entre Chris e Otelo se dá por meio da ideia do estranho, do desconhecido, do intruso. No filme, a ópera associa o irlandês ao mouro de Veneza, enunciando que se trata do fim do personagem como sujeito: "este é o fim da glória de Otelo."265

\footnotetext{
263 "Ora e per sempre addio sante memorie".

264 "Addio, sublimi incanti del pensier!"

265 "Della gloria d'Otello è questo il fin."
} 
Enquanto a Sra. Eastby toma remédios - novamente o ato cotidiano -, Chris monta com dificuldade e desespero a arma de caça da família Hewett. A cena retoma a conversa no porão na qual o patriarca e o protagonista conversam e o momento em Chris pega a arma do sogro às escondidas. Diferentemente do patriarca, que é um atirador profissional, o exprofessor de tênis não sabe manejar a arma. A prática do tiro é apresentada no filme - assim como a ópera, a literatura, as artes plásticas, arquitetura - como distinção de classe associada à família Hewett.

A angústia e o sofrimento do protagonista ao montar a espingarda contrastam com o problema com o sinal de tevê que entretém a vizinha: "Funcionava bem antes. Eu estava com ela ligada e estava boa." Nesse ponto, o executivo, vestido de sobretudo preto, aponta a arma para a câmera. O movimento associa Chris ao patriarca. No porão, conforme já demonstramos, Alec oferece um curso de administração ao futuro genro, ao passo que monta a arma de caça da família e a aponta para a câmera. Após a conversa entre Chris e o patriarca, Tom oferece a espingarda para Chris. Alec, durante a cena do tiro no campo, avisa que transformará Chris em um "talentoso atirador". A cena do assassinato no apartamento do subúrbio coloca Chris como um atirador em nome dos valores da grande corporação, do empreendedorismo, do casamento com a família Hewett, da propriedade no campo, em Englefield (o campo de batalha dos ingleses) e na cidade, no Parliament View (o edifício espelhado com vista para o Parlamento britânico). O conflito de Chris assemelha-se ao dilema de Clyde: "Ele deve ou esquecer para sempre a carreira e o sucesso social, ou livrar-se da moça. As aventuras de Clyde em seus choques com a realidade norte-americana já haviam moldado sua psicologia, de modo que, após uma longa luta interior (não devido a princípios morais, mas à sua própria e neurastênica falta de caráter), ele se decide pela última opção."266

No apartamento do subúrbio, a vizinha recorda-se que o nome do companheiro de Nola era Harris. Na ópera, ouve-se Iago pedir a Otelo: "Paz, senhor.",267 Otelo chama-o de desgraçado pelas calúnias contra a esposa e pede "uma prova segura de que Desdêmona é impura" 268 . No filme, Chris caminha com a arma apontada em direção à câmera - para o espectador. Ele dirige-se ao cômodo onde a Sra. Eastby toma os remédios. O aspecto negro do protagonista, ressaltado pela vestimenta e pela iluminação do local, relembra o mouro de Veneza e o quadro na galeria de Chloe da sombra azul, onde Chris telefonara para Nola.

\footnotetext{
${ }^{266}$ Eisenstein, p.99.

267 "Pace, signor."

268 "Una prova secura che Desdemona è impura".
} 
Na ópera, Otelo contesta Iago e pede por uma prova visível: "Não fuja! Nada te ajuda! Quero uma segura, uma visível prova!" ${ }^{269}$ Fechando o frasco de remédios, a Sra. Eastby olha para a câmera em direção ao assassino. Em um rápido contra-plano, observa-se Chris atirar contra a vizinha. A arma de fogo e o barulho do tiro invadem a ópera. Após o tiro, não ouvimos mais a voz dos personagens no filme, apenas a música extra-diegética na voz de Otelo e Iago narram os acontecimentos.

Ao disparar contra a Sra. Eastby, Chris treme. Ele cai no chão após o disparo. O protagonista é tomado pelo desespero e chora. Chris retorna para a sala do apartamento da Sra. Eastby e começa a revirar os pertences da vizinha, simulando um assalto. A cena no porão, na qual Chris recebe a arma de caça dos Hewett, o negócio fechado pelo executivo na grande corporação, a loja onde Nola trabalha, o esquecimento da Sra. Eastby, a manteiga de amendoim como isca para ratos e o problema com o sinal de tevê retomam a ideia de eventos do cotidiano que são apresentados no filme de maneira causal, associando os eventos rotineiros às ações financeiras e do Estado. O filme retoma a ideia do "monopólio da violência legítima [...] a violência sobre a qual o Estado e a sua civilização repousam"270.

O mouro de Veneza é "um servo do Estado veneziano"271, um mouro que usa turbante, conforme lembra Sinfield. Otelo é um enviado do Estado para matar os turcos e a transviada Desdêmona que desafia o pai ao casar-se com o mouro. Otelo acaba apunhalando a si mesmo como um turco, restabelecendo a ordem em nome da sociedade Veneziana. Por sua vez, Chris é um irlandês, aliado ao império britânico, que mata sua companheira, Nola Rice (uma atriz faminta do Colorado), e a vizinha, uma Sra. chamada Eastby. Chris, portanto, restabelece a estrutura social ao cometer os assassinatos e, nesse ponto, o filme pode ser comparado a Otelo, "no sentido de que não são os indivíduos, mas as estruturas de poder que produzem o sistema dentro do qual nós vivemos e pensamos" ${ }^{272}$. O Englefield Estate, a Swiss Re e o Parliament View simbolizam, no filme, as estruturas de poder no Reino Unido.

Na cena do assassinato da Sra. Eastby, observa-se um saqueio: Chris rouba os remédios, o relógio e os anéis da vítima. $\mathrm{O}$ anel de casamento retoma a ideia da aliança com os Hewett. O saqueio não é contra os ricos, mas sim contra a vizinha no apartamento no subúrbio. $\mathrm{O}$ aspecto corriqueiro do assassinato volta à tona quando se observa Nola saindo da

\footnotetext{
269 "Non sfuggir! nulla ti giova! / Vo' una secura, una visibil prova!"

${ }^{270}$ Sinfield, p.34-35.

${ }^{271}$ Ibid, p.34.

272 Ibid, p. 37.
} 
loja, de seu local de trabalho. Allen contrapõe o desespero do assassino no apartamento do subúrbio à calmaria da transeunte que caminha pela rua. Novamente, a utilização da ópera no filme aproxima Nola e Desdêmona. Assim como a heroína shakespereana, a norte-americana é "uma mulher que poderia provocar uma crise na história patriarcal [...]. Ela coloca o sistema em desordem" 273 e por isso, deve ser eliminada pelo próprio sistema por meio de seus agentes. Nola fora extinta, primeiramente, pela família Hewett.

No apartamento da Sra. Eastby, Chris chora sentado no sofá da vítima. Ele chuta a bolsa da vizinha, objeto relacionado ao dinheiro. No filme, observa-se um movimento de resistência na "apresentação de todo o curso de pensamento de uma mente perturbada." "274 A câmera volta a destacar o aspecto rotineiro do assassinato, como se o crime fosse a regra, reinstaurando a ordem. Na esquina da Ledbury Road, Nola chama um táxi. Allen contrapõe, por meio de dois cortes rápidos, o sofrimento do protagonista no apartamento da vizinha à calmaria na rua. Enquanto o assassino "sofre e ruge!"275, a vítima dirige-se à residência após o trabalho, como uma transeunte qualquer. Nola e a Sra. Eastby compartilham um destino comum. Chris guarda os pertences da Sra. Eastby na mochila de tênis. O protagonista olha para o relógio, marcando a ideia de um crime premeditado que assim como o trabalho é controlado pelo tempo.

Allen corta para a fachada do Palace Theatre, onde está em cartaz o musical The Woman in White. O carro da família Hewett aproxima-se do teatro, Chloe sai do veículo e pega os ingressos. Novamente, é destacado o aspecto cotidiano dos eventos. O relógio antigo da casa da Sra. Eastby indica o horário marcado para o crime que coincide com a programação acertada com a jovem herdeira e reitera a ideia de um crime comum tal como a passagem do tempo. Na sala do apartamento do subúrbio, o executivo coloca uma nova bala na espingarda.

Na rua do apartamento de Nola, observa-se a chegada de um táxi. Nola sai do veículo e caminha em direção à câmera. A cena também estabelece paralelo com a chegada de Chris ao edifício no subúrbio, ressaltando o evento cotidiano e aproximando o crime do espectador. Nesse momento, ouve-se a música extra-diegética, na qual Iago prossegue relatando o suposto sonho de Cássio a Otelo: "Desdêmona doce! O nosso amor se esconde." 276 Apesar de se tratar

\footnotetext{
${ }^{273}$ Ibid, p.45.

${ }^{274}$ Eisenstein, p.104.

275 "Soffri e ruggi!"

276 "Desdemona soave! Il nostro amor s'asconda."
} 
da narrativa de Iago, a utilização deste trecho da ópera, neste momento específico do filme, retoma o amor de Chris por Nola. A câmera retorna para o protagonista que coloca as balas na espingarda. Observa-se um vizinho descendo as escadas, o que mostra que mesmo após o assassinato da Sra. Eastby, a rotina dos moradores permanece inalterada. Outro indício do cotidiano dos moradores ocorre no momento em que o vizinho Ian [Colin Salmon] tenta chamar a Sra. Eastby: "Eu vou à loja da esquina, quer que eu lhe traga algo?" Dentro do apartamento da vizinha, o protagonista caminha em direção à câmera com a espingarda em punho. Chris esconde-se atrás da porta e escuta o chamado do vizinho. Na ópera, Iago prossegue relatando a Otelo o suposto sonho de Cássio. Observa-se que mesmo antes da apresentação do lencinho, Otelo já está convencido de sua inferioridade frente a Cássio e aos venezianos e da traição de Desdêmona.

No interior do apartamento da vizinha, o protagonista ouve o chamado de Ian. Novamente, o cotidiano do edifício, representado por Ian, e o desespero de Chris aparecem lado a lado, separados pela porta do apartamento da Sra. Eastby. Chris cometerá os assassinatos, sem que os vizinhos percebam. Ao sair do edifício, Ian encontra Nola. Os dois conversam sobre um tocador de cd portátil. Novamente, acentua-se o aspecto da conversa trivial.

Da escadaria do prédio em contre-plongée, a câmera focaliza o protagonista. A imagem de Chris aparece por meio das estruturas metálicas que compõem o corrimão da escada. O assassinato de Nola dar-se-á próximo à escadaria do edifício no subúrbio. Nesse ponto, a imagem das escadas no Englefield Estate, na casa da cidade dos Hewett e no Parliament View pode ser retomada para destacar a ideia do arrivismo do protagonista. Chris vigia a chegada de Nola por meio do vão da escadaria e olha para o relógio, ao passo que a voz de Otelo reafirma o sofrimento do protagonista: “Oh monstruosa culpa!" ${ }^{277} \mathrm{Na}$ entrada do edifício, Nola despede-se do vizinho, no momento previsto.

$\mathrm{Na}$ ópera, Iago explica a Otelo que se trata apenas de um sonho: "Eu não narrei mais do que um sonho",278 Otelo precipita-se a Iago, ao afirmar que se trata de: "Um sonho que revela um fato" 279 , antes mesmo da apresentação do lencinho. Iago, por sua vez, apresenta que o sonho pode apresentar outro indício: "um sonho que pode dar forma de prova a um outro indício. Nesse momento, Nola entra no prédio. Do lado de dentro do edifício, Chris observa

\footnotetext{
277 “Oh! mostruosa colpa!”

278 "Io non narrai che un sogno."

279 "Un sogno che rivela un fatto",
} 
Nola. Ele aponta a arma para o vão da escada e, novamente, olha para o relógio, ressaltando o aspecto do tempo controlado, da pontualidade, característica inglesa da eficiência e do trabalho. A iluminação escura da cena permite que se observe o protagonista como uma sombra negra. Portanto, a proximidade entre Otelo e Chris não se dá apenas pela música, como também se faz presente na diegese por meio do aspecto sombrio, da culpa e do desespero do protagonista.

Nesse ponto, no qual Chris aguarda Nola com a arma apontada para o vão da escada e próxima à câmera, a música extra-diegética é cortada. Allen opta por não apresentar o momento da ópera no qual Iago traz o "indício" para Otelo, o lencinho de Desdêmona ${ }^{280}$. Ao cortar este fragmento específico da ópera, o filme comenta Otelo, mostrando, conforme já argumentamos, que o mouro de Veneza não precisa do sonho de Cássio nem do lencinho de Desdêmona, pois desde o começo da ópera, Otelo já se considera como um intruso, um bárbaro, imagem que lhe é atribuída pelos venezianos.

Semelhante movimento ocorre em Match Point: Chris reafirma a ordem patriarcal ao cometer os assassinatos de Nola e da Sra. Eastby. O filme apresenta todos os passos do crime: da trajetória de aliança do irlandês com as classes dominantes britânicas, à possibilidade - ao lado de Nola - de saída do claustro e à execução da companheira. Durante a cena do assassinato, Allen retira o momento do lenço e passa a repetir pequenos fragmentos da ópera. Ouve-se a voz do tenor e do barítono e é possível identificar algumas palavras, tais como, "culpa", "amor" e "suspiros". Reitera-se a indicação da morte do sujeito, tomado pela culpa. Os "suspiros" retomam a ópera de abertura $O$ Elixir de Amor, na qual Nemorino suplica pelos suspiros da amada.

No plano da imagem, Chris fica à espreita de Nola. O movimento é rotineiro: a moradora sai do elevador e encaminha-se para o seu apartamento, sem perceber a presença de Chris. Observa-se o protagonista segurar a espingarda e atirar contra Nola em direção à câmera e também contra o espectador. Há um rápido corte, onde se observa Chloe em frente

\footnotetext{
${ }^{280}$ O uso da ópera Otelo faz lembrar o romance Dom Casmurro, de Machado de Assis. Em Dom Casmurro, a ópera Otelo é uma pista para desmascarar o discurso de Bentinho. No plano narrativo, Otelo ajuda o narrador a se convencer a cometer os crimes, em outro plano, Otelo é uma pista para desmascarar o narrador. É sabido que, ao assistir a ópera Otelo, Bentinho decide que não ele, "mas Capitu devia morrer". O patriarca brasileiro chega a dizer que se Otelo foi capaz de estrangular a amada que era inocente por um simples lenço: “(...) que faria o público se ela deveras fosse culpada? Tão culpada como Capitu? E que morte lhe daria o mouro? Um travesseiro não bastaria; era preciso sangue e fogo, um fogo intenso e vasto, que a consumisse de todo, e a reduzisse a pó, e o pó seria lançado ao vento, como eterna extinção..." Ver Assis, Machado de. "Dom Casmurro". In: Obras completas - vol.1. Rio de Janeiro: Nova Fronteira, 2004, p.935.
} 
ao Palace Theatre à espera do marido para o musical. A ida ao teatro aparece também como atividade cotidiana. Outros transeuntes passam em frente ao teatro.

A câmera retorna para o apartamento no subúrbio. O executivo sai pela entrada do prédio, retirando as luvas. Chris esbarra em um transeunte e assusta-se com o encontro fortuito. Na ópera, Otelo grita: "Sangue, sangue, sangue". Mas, o cotidiano se restabelece, o transeunte prossegue seu caminho e em frente ao teatro, Chloe telefona para o marido. Chris encaminha-se para o encontro com a esposa de táxi. Pelo telefone, o protagonista comunica a Chloe que está a caminho. Durante o percurso até o Palace Theatre, Chris chora e desesperase. A música extra-diegética acompanha a conversa entre o marido e a esposa, comentando-a. Pode-se ouvir o dueto de Otelo e Iago: "Pela morte e pelo mar obscuro destruidor!"281

A cena seguinte apresenta Chloe e Chris descendo as escadarias de mármore do teatro. Nesse ponto, a ópera é interrompida. O protagonista deixa seu casaco e sua mochila de tênis (onde está a arma do crime e os pertences da Sra. Eastby) na chapelaria do local. Na cena, evidencia-se que o executivo e sua esposa são insuspeitos, frequentadores do teatro. $\mathrm{Na}$ plateia, entre os outros espectadores, a câmera apresenta o olhar hipnotizado da herdeira para a apresentação e os olhos marejados de lágrimas do protagonista - semelhante a "furtiva lágrima" de Nemorino. Na análise sobre o uso da ópera no teatro, Brecht avisa, "a música mais 'avançada' hoje em dia ainda é escrita para as salas de concerto. Um único olhar para o público que frequenta os concertos é suficiente para mostrar como é impossível fazer qualquer uso político ou filosófico da música que produz esses efeitos. Vemos fileiras inteiras de seres humanos transportados para um estado peculiar de dopagem, totalmente passivo, afundados como uma pedra, aparentemente sob o domínio de um envenenamento grave. O seu olhar tenso, congelado mostra que essas pessoas são vítimas indefesas e involuntárias de suas emoções incontroláveis e desenfreadas. Gotas de doces provam como tais excessos os exaurem. O pior filme de gangster trata o seu público mais como seres pensantes. A música é escalada para o papel do Destino. Como o destino extremamente complexo, totalmente nãoanalisável desse período horrendo, da exploração mais deliberada do homem pelo homem. Essa música não tem nada, mas apenas as ambições puramente culinárias. Ela seduz o ouvinte em um enervante, porque improdutivo, ato de divertimento. Nenhum refinamento pode me convencer de que a sua função social é diferente daquela dos burlescos da Broadway"282.

\footnotetext{
281 "Per la Morte e per l'oscuro mar sterminator!"

${ }^{282}$ Brecht, 1977, p. 89.
} 
A preferência dos Hewett pelo musical qualifica o gosto pela ópera enquanto entretenimento. Conforme argumenta Brecht, "a ópera é vendida como entretenimento noturno e isso coloca limites definitivos para todas as tentativas de transformá-la. Vemos que esse entretenimento tem que ser dedicado à ilusão, e deve ser de um tipo ceremonial" ${ }^{\text {283 }}$. Em Match Point, o musical figura como um modo privilegiado para qualificar o showbusiness, no qual prevalecem os efeitos especiais, o fetiche da tecnologia. Após o assassinato, Chloe e Chris dirigem-se ao show de entretenimento noturno. Enquanto assistem hipnotizados à apresentação, ouve-se o início da música diegética. No filme, a melodia é invadida e interrompida pelas sirenes de polícia. Para o espectador, a referência a The Woman in White relembra Nola, porque retoma o conflito do jovem professor e das mulheres de branco contra a estrutura patriarcal, o casamento arranjado, a propriedade e a herança.

\subsection{Arrivismo contemporâneo}

\footnotetext{
"Também aqui o dinheiro é pré-condição; a sua falta de memória dá viabilidade ao putschismo social. Isto dirá respeito às qualidades pessoais do arrivista: menos que desprezar inclinações em geral, saberá ajustar as suas ao momento, para assim valorizá-las e ser homem com preferências úteis."

Roberto Schwarz, "Dinheiro, memória, beleza (O pai Goriot)".
}

O espetáculo no Palace Theatre (local que combina apresentações de ópera e musical), após o assassinato de Nola, mostra o protagonista inerte contemplando o show de entretenimento ao lado da esposa. A mochila de tênis do executivo, deixada no guardavolumes do teatro, é insuspeita, pois pertence ao casal da alta sociedade.

A cena do assassinato retoma também o romance Crime e castigo, de Fiódor Dostoievski. Conforme exposto no primeiro capítulo, a obra é consultada pelo tenista, que prefere a coletânea de ensaios Cambridge Companion to Dostoievski à leitura do romance. Assim, a literatura tem função definida para Chris e em certo sentido, ela pode ser comparada ao papel que os salões da aristocracia exerceram para Julien Sorel em $O$ Vermelho e o negro: "Valem pelo prazer de citá-los depois que se sai deles"284. O romance de Stendhal aponta também para a ópera como um dos atributos necessários para Julien Sorel entrar para a alta sociedade. O senhor de La Mole aconselha-o:

\footnotetext{
${ }^{283}$ Ibid., p.41.

${ }^{284}$ Stendhal [1783-1842]. O Vermelho e o negro - trad. Raquel Prado. São Paulo: Cosac Naify, 2003, p.332.
} 
Mas tenho um favor a lhe pedir que só lhe custará uma pequena meia hora de seu tempo: todas as noites de espetáculo, às onze e meia, assista no vestíbulo à saída da alta sociedade. Ainda percebo no senhor modos da província, é necessário livrar-se deles; aliás, não lhe faria mal conhecer, pelo menos de vista, os grandes personagens junto aos quais posso algum dia mandar-lhe em alguma missão. Apresente-se na bilheteria do teatro; reservaram-lhe entradas. ${ }^{285}$

O filme localiza esta função ao mostrar que a predileção de Chris por Dostoievski desperta o interesse do patriarca Alec Hewett pelo futuro genro. Assim como o curso de administração, a prática de tênis e de tiro, o gosto por ópera e por literatura compõem "um conjunto de habilidades, capacidades e destrezas úteis a determinados processos econômicos"286: elas são apresentadas no filme como investimentos fundamentais para o arrivismo do protagonista. A trajetória de Chris, apresentada no filme, seria uma espécie de arrivismo contemporâneo. Chris é selecionado, cooptado e incorporado pela lógica do capitalismo financeiro, corporificada na família Hewett e em suas estruturas de poder. Conforme demonstramos no capítulo I, o espírito do capitalismo contemporâneo aparece cifrado na figura do empreendedor.

Segundo o Houaiss, em português, o adjetivo arrivista é considerado um galicismo pelos puristas, que sugeriram em seu lugar: "oportunista", "aventureiro", "ambicioso". O arrivista é aquele que "se determinou a triunfar a qualquer preço, mesmo em prejuízo de outrem" 287 . Na literatura, o arrivismo é um tema central que foi analisado amplamente. Uma das formulações sobre o tema pode ser encontrada no ensaio de Roberto Schwarz sobre o romance $O$ Pai Goriot, de Balzac. Segundo Schwarz, o arrivista coloca-se a venda por inteiro, ele "vira mercadoria ele próprio. Estar vestido e disposto segundo a voga é questão de vida ou morte; menciona-se um par de calças bem cortadas que teria valido ao dono um casamento milionário. Quando faz suas, em consciência, as regras do sistema, o putschista inflige a si mesmo, de golpe, as limitações e falsidades que os outros homens sofrem como lenta imposição da vida. Vem daí a sua força romanesca; explicita o que acontece aos mais. Passa de vítima a comparsa da violência social. Embora seja sinistra a sua adesão às forças destruidoras do sistema - adotá-las em sua crueldade para não sofrê-las - existe algo de

\footnotetext{
${ }^{285}$ Idem, p. 296.

${ }^{286}$ López-Ruiz, op.cit., p. 26-27.

287 Segundo o verbete do Houaiss Online. Disponível em: <http://houaiss.uol.com.br/busca.jhtm?verbete=arrivista\&cod=22144 > . Acesso em: 13 jun. 2010.
} 
libertador no realismo dessa atitude, que não luta lutas vãs. Na prática do putschismo e na consciência que ela implica aparece a verdade sobre as relações de poder e propriedade na sociedade competitiva e antagônica" 288 .

O filme estabelece relação com a temática do arrivismo, por meio da trajetória do protagonista. A referência ao romance de Dostoievski no filme permite que comparemos a trajetória de Raskólnikov e a de Chris. Os crimes cometidos por Chris assemelham-se aos de Raskólnikov. Nesse sentido, retomaremos alguns excertos do romance russo que revelam o diálogo estabelecido pelo filme entre Crime e castigo e Match Point.

Além da idade das vítimas e de serem mulheres, o crime é realizado de maneira semelhante. O jovem estudante russo mata a velha usurária e a irmã caçula de Aliena Ivánovna, Lisavieta, que "já estava com trinta e cinco anos" $" 289$. Raskólnikov entra "sem ser convidado" 290 no apartamento de Aliena Ivánovna. A velha usurária recebe o penhor do estudante e para conferir a autenticidade da cigarreira de prata "por alguns segundos lhe deu as costas" 291 . Quando a velha irritada percebe tratar-se de uma armadilha, ela grita e caminha em direção ao estudante. Nesse momento, Raskólnikov tira o machado por inteiro e "mal se dando conta de si, e quase sem fazer força, quase maquinalmente, baixou-o de costas na cabeça dela" ${ }^{, 292}$. O estudante arranca o cordão da senhora, a bolsa de camurça abarrotada, um anelzinho e inicia o saque:

Lançou-se a revirar tudo. De fato, no meio da traparia haviam sido colocados objetos de ouro - provavelmente tudo penhores resgatados e não resgatados -, pulseiras, correntes, brincos, alfinetes etc. Alguns estavam em estojos, outros simplesmente embrulhados em papel de jornal, mas em folhas duplas, com cuidado e zelo, e amarrados em círculo por cadarços. Sem qualquer demora, ele passou a encher os bolsos da calça e do sobretudo, sem examinar nem abrir os embrulhos e estojos; mas não teve tempo de pegar muita coisa...",293

Desse modo, é possível apontar semelhanças no momento da execução do crime: não só a forma pela qual o assassino invade a casa da senhora; mas também a utilização de armas rústicas (tanto a espingarda utilizada por Chris, como o machado de Raskólnikov foram

\footnotetext{
${ }^{288}$ Schwarz, Roberto. "Dinheiro, memória, beleza (O pai Goriot)". In: A Sereia e o desconfiado. Paz e Terra, 1981, p.181-182.

${ }^{289}$ Dostoievski, Fiódor. Crime e castigo. Trad. Paulo Bezerra. São Paulo: Editora 34, 2001, p.79.

${ }^{290}$ Ibid., p. 90 .

${ }^{291}$ Ibid., p.91.

${ }^{292}$ Ibid., p.91.

${ }^{293}$ Ibid., p.93.
} 
“emprestados"); e a indicação de que se trata assassinos inexperientes; ou os objetos roubados da vítima que serão guardados no bolso do criminoso (o anel, os colares e outras joias) e o momento em que os assassinos são quase surpreendido pelos vizinhos e desesperam-se. Todavia, há uma diferença fundamental entre os crimes: no caso russo, trata-se do assassinato de uma velha usurária. Conforme afirma Raskólnikov, "o segundo assassinato foi totalmente inesperado" ${ }^{\text {294 }}$. A jovem Lisavieta é morta, tão somente porque surpreende o assassino. Por sua vez, em Match Point, o assassinato da Sra. Eastby e o roubo de seus pertences servem como armadilha aos policiais, o motivo do crime é a eliminação da jovem Nola Rice.

Raskólnikov compara o assassinato de Aliena Ivánovna às batalhas de Napoleão: "Napoleão, as pirâmides, Waterloo - e uma viúva de registrador, sórdida, descarnada, velha, usurária, com o bauzinho vermelho debaixo da cama [...]"295. Conforme explica Georg Lukács no famoso ensaio sobre Dostoievski: "Napoleão é o símbolo do bastonete de marechal, daquele bastonete de marechal que se diz que cada pessoa de talento leva na mochila desde a Revolução Francesa. Esse Napoleão é o símbolo das possibilidades ilimitadas que a inteligência tem na sociedade democrática e, ao mesmo tempo, a verdadeira medida do caráter democrático da sociedade, 296 .

De acordo com Lukács, no caso de Raskólnikov, “ (...) o problema concreto para ele é quase exclusivamente o problema psicológico-moral: a capacidade de Napoleão para ir em direção a grandes objetivos, passando sobre corpos humanos - capacidade que é comum, por exemplo, a Napoleão e a Maomé. Desse ponto de vista psicológico, a ação em si torna-se ainda mais contingente, constituindo mais um ponto de partida e não um fim efetivo ou meio concreto. E eis que no centro movimenta-se de maneira decisiva a dialética psicológica e moral pró e contra a ação; a grande prova de fogo é: existiria em Raskólnikov a capacidade de transformar-se em Napoleão? Então a ação concreta transforma-se numa experiência cujo ponto de referência é a participação completa do experimentador, uma experiência cujo "ponto contingente" e "objeto" contingente é a vida de uma outra pessoa."297 Para Lukács, a questão central do romance seria: "Raskólnikov será capaz de suportar psicologicamente o fato de haver ultrapassado os limites morais?” ${ }^{298}$ De acordo com Lukács, Dostoievski foi o primeiro que "fixou os sintomas da deformação psíquica que necessariamente surge no campo

\footnotetext{
${ }^{294}$ Ibid, p.94.

${ }^{295}$ Ibid., p. 284.

${ }^{296}$ Lukács, Georg. "Dostoievski”. Ensaios sobre literatura. Rio de Janeiro: Civilização Brasileira,1965, p.147.

${ }^{297}$ Ibid, p. 148.

${ }^{298}$ Ibid, p. 149.
} 
social da vida na grande cidade moderna. ${ }^{299}$ E nesse sentido, ele será de importância crucial para Allen, cineasta que, ao longo de sua obra, tematiza a deformação psíquica dos indivíduos na cidade grande.

O desespero de Chris na cena do assassinato mostra que a possibilidade de mudança, de vida autêntica ao lado de Nola já não é mais possível. O protagonista estará condenado ao modo de vida dos Hewett. Trata-se novamente da reposição da ordem dominante. Na análise de $O$ pai Goriot, Schwarz lembra que "a competição individualista exige também, para continuar competição e individualista, que não deixem de existir vinculações irracionais e particularistas - i.é, nexos cuja substância está na exclusividade com relação aos outros e na limitação quanto ao próprio eu. A irracionalidade do todo social antagônico, em que os homens não aproveitam uns aos outros, mas uns dos outros, parece ter por correlato a irracionalidade na esfera pessoal mais estrita; o eixo da experiência será a exclusividade, com seu corolário de autolimitação e mutilação; paradigmas são a propriedade privada e o amor burguês. A existência aparece como um agarramento monstruoso e irracional à vida, pois a sua justificativa mais radical, dar e receber prazer, não lhe orienta o curso."300

\subsection{A espetacularização do assassinato}

Diferentemente do estudante pobre Raskólnikov, que após o crime recebe uma intimação policial por causa de uma ação de cobrança de dinheiro, o executivo da transnacional vai para o musical com a herdeira. Do musical, Allen retorna para o conjunto de prédios no subúrbio onde os policiais da Scotland Yard iniciam a investigação. No filme, pode-se observar o comentário de Allen sobre a espetacularização do assassinato em detrimento da investigação. A notícia da morte de Nola e da Sra. Eastby será analisada neste trabalho como reflexo do que Susan Willis demonstra a partir da análise rigorosa do cotidiano pós-11 de setembro: “Cegos diante da história e sufocados pelo entretenimento, estamos condenados a ler evidências como mero espetáculo.”301

Logo na primeira cena após o encontro do casal no Palace Theatre, observa-se a entrada do edifício de Nola que está fechada por policiais. No interior do apartamento da Sra. Eastby, um fotógrafo registra a ocorrência. Entre os policiais, a resolução do crime parece

\footnotetext{
${ }^{299}$ Ibid, p.155.

${ }^{300}$ Schwarz, 1981, p.184-185.

${ }^{301}$ Willis, Susan. Evidências do real: os Estados Unidos pós-11 de setembro. São Paulo: Boitempo, 2008, p.104.
} 
estar concluída. O motivo do assassinato estaria relacionado a drogas e tratar-se-ia de uma cena corriqueira, uma fatalidade:

[Policial]: "É uma cena terrível, senhor."

[Detetive]: "O que aconteceu é bastante óbvio. Alguém roubou e matou a senhora. Quando eles estavam fugindo, encontraram a senhorita Rice. Então, atiraram nela também por pânico ou porque viram uma chance de roubar alguma coisa a mais. Pobre alma inocente chegou em casa na hora errada."

[Policial]: "Eles roubaram os remédios com receita".

[Detetive]: "Ah, é definitivamente um roubo relacionado às drogas. Eles deviam saber que uma senhora morava no apartamento oito e provavelmente foram surpreendidos pela chegada da outra mulher."

[Policial]: "Ela escolheu a hora errada para voltar para casa. Algumas pessoas não têm nenhuma sorte."

Por um lado, os policiais caem na armadilha preparada pelo assassino: o roubo dos remédios e das joias pode ser interpretado como uma espécie de "elixir", vendido pelo charlatão Dulcamara, ou como o lencinho, utilizado por Iago para que Otelo acreditasse na "traição" de Desdêmona. Por outro, pode-se observar que a conclusão do detetive de que se trata de um crime "óbvio" relacionado a drogas reitera o aspecto inconteste, de um crime comum. Ao narrarem o crime, os policiais apresentam um destino comum para Nola e a Sra. Eastby. Trata-se de uma história característica dos moradores do subúrbio londrino. O policial destaca que "algumas pessoas não têm nenhuma sorte", em especial, as que residem em bairros como este. A tragédia deixa de ser individual e adquire aspecto corriqueiro, geral: "a tragédia que ocorre a toda hora e a cada minuto" ${ }^{, 302}$ em Londres, fora dos filmes.

No lado externo do conjunto de prédios, a testemunha (Ian, o vizinho) é interrogada pelo inspetor de polícia Dowd [Ewen Bremmer]. Pode-se observar o comentário irônico de Allen a respeito da Scotland Yard, considerada como uma das melhores equipes policiais do mundo. Segundo o site da polícia londrina, "um dos princípios chave da polícia moderna no Reino Unido é que a polícia procura trabalhar com a comunidade e como parte da comunidade 303 . O cenário retratado pelo filme é bastante diverso da versão oficial da polícia $^{304}$. Vê-se a falta de interesse do inspetor em ouvir o relato da testemunha. O homem negro é reiteradamente interrompido pelos policiais:

\footnotetext{
${ }^{302}$ Eisenstein, op.cit., p.103.

${ }^{303}$ Disponível em: <http://www.met.police.uk/history/definition.htm>. Acesso em: 13 mar.2010.

${ }^{304}$ Filmado em 2004 e lançado em 2005, Allen não poderia prever o assassinato do brasileiro Jean Charles de Menezes, morto a tiros no metrô londrino por policiais da Scotland Yard, em julho de 2005. No entanto, o filme
} 
[Testemunha]: "Eu acabei de falar com ela, isso é inacreditável. Há meia hora atrás, eu desci as escadas, bati na porta da Sra. Eastby, porque..."

[Funcionário da polícia]: "Precisa de algo que esteja no carro?"

[Inspetor de polícia]: "Sim, apresse a perícia para que isso ande logo, porque isso aqui já está ficando ridículo."

[Testemunha]: "Isso é muito importante. Ela normalmente faz pães neste horário e eu achei que ela poderia querer alguma coisa que estivesse faltando. Então, eu perguntei a ela se precisava de algo e depois..."

[Inspetor]: "Então, você falou com ela há meia hora atrás?"

[Testemunha]: "Sim, há meia hora."

[Inspetor]: "Então, ele ainda estava lá dentro."

[Testemunha]: "Isso é terrível, inacreditável." coisa?"

[Inspetor]: "Você falou com a Nola Rice e ela lhe disse alguma favor?'

[Fotógrafo]: "Podemos deixar os fotógrafos entrarem agora, por

[Inspetor]: "Não esperem um pouco. A gente precisa que a perícia entre lá primeiro."

O inspetor Dowd tenta impedir a entrada do fotógrafo. Ele ordena a um funcionário, que atende pelo mesmo nome do protagonista, que acompanhe o fotógrafo: "Chris, você pode falar com esse homem aqui? Espere. Espere. Fale com ele ali." No entanto, mesmo sem a autorização do inspetor de polícia, o fotógrafo entra no local. Dowd determina que outro policial encontre o fotógrafo do lado de dentro do edifício. Após a discussão entre os policiais, a testemunha tenta retomar o seu relato: "Eu encontrei com a Nola aqui na frente do prédio.” Ian é novamente interrompido por um policial: “A equipe de perícia está chegando, ok?” A reiteração das interrupções para com o homem negro revela o racismo entre os policiais. Se fosse branco e morasse em outro local, provavelmente, ele seria ouvido.

Para os policiais, os crimes são previsíveis e por isso eles querem "apressar" a investigação. O inspetor considera que a situação "já está ficando ridícula", como se não houvesse mais espaço para nenhuma verificação. Assim, ao relacionar a operação policial com a entrada da mídia na cena do crime, o filme revela que a urgência dos policiais deve-se às necessidades dos meios de comunicação em massa. Os assassinatos precisam ser

captura um aspecto crucial do sistema londrino ao mostrar o preconceito racial entre os policiais para com o homem negro. No assassinato de Jean Charles, que por ser estrangeiro foi confundido com um terrorista, ficou claro que a Scotland Yard cometeu uma série de erros injustificáveis. Todavia, assim como Nola e a Sra. Eastby, em assassinatos de pessoas pobres assim como Jean Charles, ou os irlandeses que foram mortos no que ficou conhecido como Bloody Sunday, não há condenação dos criminosos. No julgamento dos policiais pela morte do brasileiro, os advogados da polícia argumentaram que "a família do eletricista Jean Charles por ser muito pobre irá receber uma compensação financeira reduzida" Disponível em: <http://www.dailymail.co.uk/news/article1230067/Jean-Charles-Menezes-Family-Brazilian-shot-dead-tube-just-fraction-400k-pay-blundering-Met-bossBlair.html>. Acesso em: 13 mar.2010. 
rapidamente elucidados para que o jornal possa sair, com fotos, no dia seguinte. A aproximação entre a polícia e a mídia na resolução dos crimes foi analisada por Debord: “Os boatos da mídia e da polícia adquirem de imediato, ou, na pior hipótese, depois de terem sido repetidos três ou quatro vezes, o peso indiscutível de provas históricas seculares" ${ }^{\text {305 }}$. O inspetor e a testemunha concentram-se nos aspectos banais:

[Testemunha Ian]: "Eu encontrei com ela aqui, a gente conversou, batemos papo, eu recomendei um aparelho eletrônico de música."

[Inspetor de polícia]: "Que tipo de equipamento de música?"

[Testemunha Ian]: "Apenas um cd player portátil."

Desta vez, o depoimento de Ian é cortado pelo detetive que estava no local do crime. Parry repete a sentença proferida no apartamento da Sra. Eastby: "Alguém que queria dinheiro para comprar drogas." A testemunha tenta avisar aos policiais: "A Sra. Eastby não era rica", o que retoma a ideia de que os moradores do prédio provêm das classes baixas. Ian tenta analisar os eventos no que eles "são diferentes de tudo o que ocorreu até o presente",306. Contudo, o detetive branco desconsidera a informação apresentada pelo homem negro:

[Detetive Parry]: "Eles não se importam. É definitivamente um caso de drogas, alguém atrás de dinheiro para comprá-las. Eles lhe matariam por uma libra, se quisessem."

[Testemunha Ian]: "É uma situação triste."

[Detetive Parry]: "Parece que a senhora não tinha inimigos, ela raramente saía... Ele usou uma espingarda."

[Testemunha Ian]: "Uma espingarda? Não é óbvio que alguém deve ter visto alguma coisa?"

[Inspetor Dowd]: "Não se a arma tiver sido cerrada. Eles podem fazê-las bem pequenas."

A indicação de que se trata de uma arma de caça chama a atenção do vizinho, mas os policiais não consideram atípico o uso da espingarda. $\mathrm{O}$ barulho de outra sirene interrompe a conversa. Os transeuntes e outros moradores do prédio observam o local como se fosse um espetáculo. O inspetor de polícia pede para que a motorista do veículo não estacione no local, pois "A SOCO [Scenes of Crime Officer] está chegando". Em detrimento do depoimento da única testemunha do crime, o inspetor de polícia tenta apressar a chegada da perícia policial

\footnotetext{
${ }^{305}$ Debord, Guy. A sociedade do espetáculo. Trad. Estela dos Santos Abreu. Rio de Janeiro: Contraponto, 1997, p. 210 .

${ }^{306}$ Debord, op.cit., p. 216-217.
} 
para que possa liberar o local do crime para a entrada da imprensa. Há na interpretação do crime feita pelos policiais uma certa parte de verdade, tendo em vista que o local é cotidianamente alvo de ladrões e ratos, no entanto, conforme lembra Debord a respeito da sociedade do espetáculo, esta verdade é “deliberadamente manipulada por um hábil inimigo"307.

A espetacularização do assassinato pode ser observada também durante a recepção da notícia da morte de Nola transmitida pelos jornais à família Hewett. No Parliament View, local que não é alvo de ladrões nem de ratos, Chloe toma café da manhã despreocupadamente com o jornal ao lado. Ela recorda-se do "musical da noite passada" e pergunta ao marido se ele gostou da apresentação. Ao lado de Chloe, Chris não aparenta culpa, ele sai do banho e responde tranquilamente à esposa que "divertiu-se muito, a música era linda." Dona de uma galeria de arte e frequentadora de shows de entretenimento, Chloe avalia que "o cantor do musical é muito bom, vou comprar ingressos para mamãe e papai”, outro indício da preferência dos Hewetts pelo showbusiness.

$\mathrm{O}$ entretenimento de massas permanece na cena: depois da conversa sobre o musical com o marido, a jovem herdeira lê as notícias de jornal. No entanto, desta vez, ela não comentará a descoberta de um novo planeta, ou o terremoto na China; a notícia de jornal relaciona-se à sua família: “Oh, meu Deus! Nola! Nola Rice! Ela foi morta em um roubo, um roubo ligado a drogas."

Enquanto Chloe surpreende-se com a notícia, a câmera permanece observando Chris que enxuga o corpo com uma toalha na sacada de seu quarto. Nesse ponto, o protagonista é vítima do olhar escopofílico, ao lado de Chloe, Chris permanece como objeto sexual, um tenista dotado de uma "energia incrível", dono de um "saque poderoso", características importantes para o "projeto de fertilização", a concepção do herdeiro monitorada pela família Hewett e por uma equipe médica.

A imagem do protagonista como objeto sexual contrasta com a figura desprovida de erotismo da esposa, que está vestida de roupão. O protagonista, portanto, é tanto objeto erótico para Chloe quanto para o espectador numa interação entre essas duas séries de olhares. Segundo Laura Mulvey, “A magia do estilo de Hollywood, em seus melhores exemplos (e de todo o cinema que se fez dentro de sua esfera de influência) resultou, não exclusivamente, mas num aspecto importante, da manipulação habilidosa e satisfatória do prazer visual.

\footnotetext{
${ }^{307}$ Ibid, p.202.
} 
Incontestado, o cinema dominante codificou o erótico dentro da linguagem da ordem patriarcal dominante" ${ }^{\text {308 }}$. De acordo com Mulvey, Sigmund Freud "associou a escopofilia com o ato de tomar as outras pessoas como objetos, sujeitando-as a um olhar fixo, curioso e controlador." ${ }^{309}$ Neste ponto do filme, este é precisamente o papel de Chloe que controla os hábitos e a vida do protagonista. Em Match Point, o olhar escopofílico relaciona-se à ordem patriarcal dominante.

Enquanto Chris conversa com a esposa sobre o musical, observamos ao lado do protagonista, na parede do quarto do casal, um quadro no qual é retratado o rosto de uma senhora (Figura 12). Diferentemente de Chris, que está de toalhas, a pintura do rosto de uma figura feminina envelhecida "não pretende provocar qualquer tipo de excitação"310. A tela assemelha-se a série de retratos que Lucian Freud - neto de Sigmund - fez de sua mãe ${ }^{311}$. Conforme argumenta Sebastian Smee, as pinturas de Freud apresentam "uma concentração nos rostos das pessoas que ele conhece; descrições de cabeças em grande plano, frequentemente com uma expressão de olhos entristecida" ${ }^{312}$. No filme, a pintura que retrata o rosto de uma pessoa idosa de olhos fechados e tristes trazem à memória do espectador a imagem da Sra. Eastby. Sem olhar para a pintura, mas atento a notícia dos assassinatos, o protagonista desce as escadas do apartamento:

[Chris Wilton]: "O que? Deixe-me ver isto. Jesus Cristo!"

[Chloe Hewett]: "Aparentemente, ela estava chegando em casa depois do trabalho e alguém que já estava lá que havia assaltado um outro apartamento e matado uma senhora encontrou a Nola por acaso, enquanto ela estava entrando no prédio, ele estava fugindo e atirou nela."

[Chris Wilton]: "Oh, meu Deus!"

A explicação para o assassinato de Nola é construída por meio do infortúnio. O acaso serve para os policiais, para o jornal e para a família Hewett como justificativa para os crimes. Segundo Brecht, são “os metafísicos da imprensa [...] que querem ver o 'elemento do destino' enfatizado em todas as relações interpessoais. O destino, que (outrora) costumava estar entre os grandes conceitos, há muito já se tornou vulgar, onde a desejada 'transfiguração' e

\footnotetext{
${ }^{308}$ Mulvey, op.cit., p.440.

${ }^{309}$ Ibid., p.440.

${ }^{310}$ Smee, Sebastian. Lucian Freud.trad. Isabel Falcão (Vernáculo Ltda., Lisboa). Taschen: 2008, p.55.

311 "Entre 1974 e 1976, Freud fez uma série de retratos de cabeças que parecem inovadoras. Não envolvem nenhuma inovação formal em particular, mas de fato, sugerem uma certa desconsideração pelas convenções da arte retratista e um grau de envolvimento que é impertinentemente desinquietante”. Ver: Smee, op.cit., p.50.

${ }^{312}$ Ibid., p.14.
} 
'esclarecimento' são conseguidas por meio da reconciliação com as circunstâncias essencialmente uma guerra de classe, onde uma classe conserta o destino da outra. Como sempre, as demandas dos metafísicos não são difíceis de cumprir. É simples imaginar tudo o que eles rejeitam apresentado de tal forma que eles aceitariam com entusiasmo"313.

O espectador pode observar que até mesmo o criminoso surpreende-se com a notícia de sua absolvição. A mentira - por ser socialmente condicionada - fora aceita rapidamente pela polícia e divulgada pelo jornal. A leitura da notícia feita por Chris, ao lado da herdeira, é oposta a leitura dos jornais feita pelo estudante Raskólnikov em uma taberna: "Ao folhear as páginas suas mãos tremiam de uma impaciência convulsiva."314 Diferentemente de Raskólnikov, Chris não será condenado, conquanto permaneça ao lado dos Hewett. Desse modo, observa-se que a verdade sobre o crime permanecerá em segredo.

O telefone da residência do casal Hewett Wilton toca. Chloe levanta-se da mesa do café da manhã para atendê-lo, deixando Chris com o jornal. Os quadros dispostos no apartamento no Parliament View de Chloe e Chris assemelham-se aos expostos na galeria de arte da jovem Hewett. Os quadros que decoram a residência, as pinturas em cores vivas da paisagem tradicional londrina ${ }^{315}$, da artista Lucy Jones, são os mesmos que estavam no depósito da galeria. Chloe é uma colecionadora de arte contemporânea, característica que "é vista como progressista e avançada" 316 no mundo-corporação.

No filme, a herdeira dirige-se ao telefone da residência, passando pelos quadros de Jones. No local onde está o aparelho, observa-se uma tela grande, o retrato de um homem negro. Para o espectador, o retrato lembra o vizinho das vítimas, Ian, a testemunha do crime cujo depoimento fora desprezado pela polícia. A pintura é semelhante a do rosto da senhora e pode ser atribuída também a Lucian Freud. Os olhos do homem negro estão fechados e abatidos (Figura 13), assim como os da senhora branca. O rosto humano, desta vez, parece desgastado pelo trabalho. Para Smee, os retratos de Freud “(...) engrenam na intensidade, em parte por intermédio de uma fidelidade esmerada e uniforme para o detalhe. Por outro, interessa-se cada vez mais pela presença tridimensional dos seus modelos e, em particular, nas

\footnotetext{
${ }^{313}$ Brecht, 1977, op.cit., p.49.

${ }^{314}$ Dostoiévski, op.cit., p.173.

315 Conforme argumenta, Chin-tao $\mathrm{Wu}$ sobre as pinturas que retratam a paisagem tradicional de Londres: "durante séculos foi política de muitos bancos britânicos, ainda que esporádica, colecionar retratos de seus presidentes ou membros da diretoria, ou encomendar prata ou outros metais preciosos para comemorar eventos específicos. Mesmo quando incidentalmente se aventuravam nas paisagens, seus gostos eram muito confinados aos de uma era anterior ou, por exemplo, às vistas tradicionais do Tâmisa ou da Catedral de St. Paul". Ver: Chintao Wu, op.cit., p.240-251.

${ }^{316}$ Ibid., p.278.
} 
idiossincrasias volumétricas, como pele flácida, estrutura óssea, musculatura, bolsas de gordura, covinhas, gorduras que reflitam a luz, cicatrizes de varicela e outras marcas. Quer levar-nos para mais perto de todas estas coisas. Até a organização das suas imagens aponta para isso: as cabeças surgem de modo a que preencham a tela, são introduzidos ângulos estranhos, e as barreiras protetoras entre o tema e o espectador são retiradas. ${ }^{\text {"317 }}$ Nos trabalhos de Freud a História aparece retratada nos corpos humanos, característica que pode ser observada também no filme de Allen.

Enquanto Chloe fala ao telefone assustada com a notícia da morte de Nola, vê-se a pintura do homem negro de olhos fechados e com o rosto pálido e alguns porta-retratos com as fotos do casal feliz, durante a cerimônia de casamento. Entre os objetos de decoração da residência, pode-se observar também o busto de uma escultura feminina, alguns livros e luminárias sobre o armário. Os objetos de decoração, em especial os porta-retratos do casal Hewett Wilton, contrastam com a notícia da morte de Nola.

No filme, as pinturas de Lucian Freud na residência da herdeira por um lado comentam a ação e por outro mostram o investimento ${ }^{318}$ de Chloe. Freud é considerado o "recorde de obra mais cara de um artista vivo"319. Conforme argumenta Chin-tao Wu, o investimento nas artes proporciona "status e honraria social que nenhuma outra forma de projeto "filantrópico" corporativo tem condições de oferecer" ${ }^{320}$. A cena em que são apresentados os quadros de Freud no Parliament View corrobora a ideia, apresentada por $\mathrm{Wu}$ de que "as melhores peças, ou melhor, as mais caras devem ser expostas no ambiente imediato, na sala ou na residência do presidente da empresa e de seus principais executivos" ${ }^{\text {} 321}$. De acordo com $\mathrm{Wu}$, as compras de arte, feitas por empresas corporativas e seus familiares, tem “os olhos voltados para a especulação, é razoável supor que as agências financeiras não perderam de vista o crescimento sem precedentes e às vezes errático dos preços da arte. [...] Mas isso não quer dizer que as taxas de retorno sobre os investimentos em arte sejam tão uniformemente altas que as agências financeiras estejam comprando arte apenas como investimento. $\mathrm{Na}$ verdade, a taxa de retorno sobre a arte oscila conforme um conjunto de variáveis, como a reputação do artista ou o ano da venda" ${ }^{322}$. Nesse sentido, a

\footnotetext{
${ }^{317}$ Smee, op.cit., p.23-24.

${ }^{318}$ Freud foi considerado por Robert Hughes como o "maior pintor realista vivo". Ver Smee, op.cit., p.31.

${ }^{319}$ Disponível em: <http://www.guardian.co.uk/artanddesign/2008/jul/01/art2>. Acesso em: 13 mar.2010.

${ }^{320}$ Chin-tao Wu, op.cit., p. 220.

${ }^{321}$ Ibid., p.253.

${ }^{322}$ Ibid., p.258-259
} 
compra das pinturas de Freud dispostas na residência do casal permite entender que "há uma alta correlação entre o mercado de arte e o de ações [...] e os lucros resultantes da venda de pinturas competem com os oferecidos pelo mercado de ações" ${ }^{\text {"323 }}$. Dispostas na residência de Chloe e Chris, as pinturas de Freud remetem às vítimas do sistema. Os olhos fechados recuperam a ideia da cegueira contemporânea, dos sujeitos "condenados a ler evidências como mero espetáculo." 324

No filme, há um breve corte para a cozinha da residência londrina da matriarca. Tanto na casa de Chloe quanto na de Eleanor o chá, as frutas e o jornal compõem o cenário, o quadro matutino da família Hewett. Ao receber a ligação do irmão, Chloe aproxima-se das pinturas da paisagem londrina de Lucy Jones ${ }^{325}$ (Figura 14). O ambiente corporativo volta à cena quando há um novo corte para o escritório de Tom onde o jovem herdeiro lê o jornal enquanto toma café:

[Eleanor Hewett]: "Eu nunca me dei bem com ela, mas isso é simplesmente trágico. É trágico."

[Chloe Hewett]: "E o Tom sabe?"

[Eleanor Hewett]: "Eu acabei de avisá-lo, ele não acredita."

[Chloe Hewett]: "Espere, espere, deve ser ele, eu ligo depois."

[Chloe Hewett]: "Alô? Sim, nós acabamos de ler no jornal e a mamãe ligou."

[Tom Hewett]: "Eu sei. Lugar errado na hora errada. Eu acho que ela deve ter atrapalhado o ladrão ou os ladrões. Não dizem quantos eram."

[Chloe Hewett]: "Até a mamãe está abalada e você sabe que elas nunca foram exatamente amigas."

A conversa, feita pelo telefone, entre os irmãos Hewett e a matriarca em torno da notícia da morte da ex-noiva de Tom é avaliada como tragédia por Eleanor e azar pelo exnoivo. No jornal, não fora mencionada a relação entre o jovem empresário britânico e a atriz norte-americana. Na estruturação do filme, a cena é importante, pois revela a ideia insidiosa

\footnotetext{
${ }^{323}$ Ibid., p. 259.

${ }^{324}$ Willis, Susan. op.cit., p.104.

${ }^{325}$ Nesse ponto, podemos apontar a diferença, que pode ser percebida no filme, entre a paisagem tradicional londrina, retratada por Jones, e os retratos de figuras humanas, característicos de Freud. Tanto Freud quanto Jones podem ser considerados como "artistas figurativos", ou seja, pintores que, dependendo da cotação no mercado das artes, poderiam receber investimentos corporativos. No entanto, a obra de Freud "é resistente a uma categorização. A sua abordagem não é facilmente classificada como um "estilo" ou um "método". Ver: Smee, op.cit., p. 91. Segundo Smee, "que outros artistas produziram imagens como esta? Não havia ninguém. Havia um trajeto prevalecente para a abstração nos dois lados do Atlântico. Mesmo os artistas figurativos estavam preocupados com o expressivo potencial de formas semi-abstratas, distorção e várias liberdades pictóricas. Nestes anos, e em termos de abordagem, os primos mais próximos de Freud deverão ter sido os pintores holandeses, como Van Eyck e Robert Campin." Ver: Smee, op.cit., p.24.
} 
do assassino narrar a notícia do crime para a família: "Eles falam aqui que houve um aumento dos crimes relacionados a drogas na região durante o último ano".

$\mathrm{O}$ argumento da imprensa e dos policiais baseia-se em um fato social, o bairro violento, confirmado por pesquisas estatísticas. É importante ressaltar que o protagonista é um “criminoso inexperiente". Chris planejou a armadilha, o assassinato da Sra. Eastby, mas não imaginou que ela seria aceita tão rapidamente. Ao incluir o crime no subúrbio nas páginas policiais do jornal, avaliado por pesquisas empíricas, o filme expande e generaliza o destino do caso particular de Nola e da Sra. Eastby, que se torna uma genuína tragédia - uma história característica dos moradores do subúrbio. Ao passo que a família de proprietários ingleses impressiona-se com o aumento da violência e dos problemas relacionados às drogas na cidade, o criminoso, protegido no Parliament View, olha para a sua insuspeita mochila de tênis onde a espingarda da família, as joias e os remédios da vítima permanecem.

Além do Parliament View, a "rede de proteção" ao protagonista - alheia aos desígnios do protagonista, uma "engrenagem social", conforme o próprio Chris descrevera ao amigo Henry - pode ser vista também na casa de campo dos Hewett. Na biblioteca ancestral - que fora palco da eliminação de Nola comandada pela matriarca -, Eleanor lê despreocupadamente uma revista. Chloe aproxima-se da matriarca: "Mamãe, tenho uma coisa para lhe contar, mas eu quero que o Chris esteja aqui."

No porão da casa de campo, o espectador observa o protagonista guardando a espingarda da família. Chris retira os pertences da Sra. Eastby da mochila de tênis e esconde os remédios e as joias nos bolsos da calça. Nesse ponto, podemos retomar o aproveitamento, feito pelo filme, do romance Crime e castigo. Destaca-se a diferença entre a tranquilidade de Chris e o enlouquecimento de Raskólnikov:

Súbito lembrou-se de que a carteira e os objetos que havia tirado do bauzinho da velha ainda continuavam todos espalhados pelos seus bolsos! Até então não lhe ocorrera tirá-los e escondê-los! Não se lembrara deles nem agora enquanto revistava a roupa! O que está acontecendo? ${ }^{326}$.

Após devolver a arma da família, o protagonista de Match Point retorna à biblioteca. Chris caminha em direção à câmera, sorri e abraça a esposa. Chloe revela as boas novas à matriarca: "Mamãe, você pode finalmente estourar o champanhe, estou grávida." Indicada pela matriarca, a concepção do herdeiro, segunda condição para a completa aceitação do

\footnotetext{
${ }^{326}$ Dostoiévski, op.cit., p.103-104.
} 
tenista irlandês pela família é alcançada. Eleanor agradece ao genro: "Eu não poderia estar mais grata."

A investigação sobre o assassinato de Nola e a Sra. Eastby interrompe a comemoração em família. De forma cortês, e sem levantar suspeitas, a governanta da casa avisa que Samantha, a secretária de Chris, está ao telefone. $\mathrm{O}$ ambiente corporativo retorna à cena. $\mathrm{O}$ filme volta para o Swiss Re, aliando as conquistas da família às decisões financeiras. Samantha informa ao patrão que o detetive Mike Banner deixou um recado e pediu para que Chris ligasse na delegacia: "Não creio que seja urgente, mas ele deixou um telefone para contato". No Englefield Estate, Chris anota o telefone do detetive, ao passo que Alec, Eleanor e Chloe comemoram a chegada do herdeiro:

[Eleanor]: "Querida, eu aposto que foi naquela noite..."

[Chloe]: "Olha só, isso é chantagem."

[Eleanor]: "Na última vez que você foi lá, ele disse que estava tudo bem, não é?"

[Chloe]: "Sim. Ele me deixou completamente calma..."

[Eleanor]: "Não acredito." tão feliz...

[Chloe]: "Ele parece estranho, deve ter algo errado... A vovó ficaria

[Eleanor]: "Medicina alternativa... Ela amaria..."

[Chloe]: "Eu gostaria que ela estivesse aqui."

Após anotar o telefone do detetive, Chris junta-se à comemoração. Tom e Heather aproximam-se, o jovem Hewett cumprimenta o cunhado: “Graças a Deus, graças a Deus. Parabéns!"

Nos jardins da casa de campo, Chris caminha em direção à câmera ao passo que telefona para o detetive: “Aqui é o Chris Wilton. Você me ligou?”. Allen corta para a delegacia de polícia, onde o detetive pede para que o protagonista compareça à polícia. Chris pergunta do que se trata, mas o detetive prefere não falar pelo telefone: "São apenas algumas perguntas e tenho certeza de que você preferirá que sejamos discretos." O detetive, portanto, conhece a família, sabe da importância da Swiss Re para a cidade e por isso oferece discrição. A polidez para com o executivo é oposta ao tratamento oferecido ao homem negro pela Scotland Yard. Na casa de campo, Chris pergunta se ele precisará levar um advogado. $\mathrm{O}$ detetive Banner [James Nesbitt] afirma que espera que não seja necessário.

Em seguida à comemoração na casa de campo pela chegada do herdeiro, Allen corta para a imagem de uma ponte, a famosa Queen's Walk - frequentada por turistas para o acesso ao London Eye. À esquerda de Chris, podemos observar o símbolo do movimento anarquista. 
Trata-se da imagem desgastada de uma pichação, inscrita em um dos blocos de sustentação da ponte. Outra indicação de arte de rua pode ser vista ao lado do símbolo anarquista. Há uma menina soltando um balão vermelho em formato de coração (Figura 15). O trabalho pode ser atribuído ao famoso grafiteiro inglês Bansky ${ }^{327}$. A referência ao movimento de resistência corrobora a introdução da música extra-diegética que acompanha a cena, a ópera Macbeth, de Verdi:

[Macduff]: "Ó Filhos, meus filhos! daquele tirano Vocês foram todos mortos, e junto com vocês A mãe infeliz!...

Ah, nas garras

Daquele tigre em que eu os deixei, a mãe e os filhos?

Ah, a mão paterna..." 328

A ária "O figli, o figli miei”, retirada do quarto ato e cantada por Caruso, apresenta as queixas de Macduff contra o reino de terror, instaurado na Escócia por Macbeth. Na ópera, Caruso canta pelos filhos e pela mãe infeliz, mortos por Macbeth: “Ah, la paterna mano...” A respeito da peça shakespeareana, Alan Sinfield traz uma importante reflexão sobre a “incapacidade de produzir herdeiros" que acomete Lady Macbeth e Macbeth. A partir da análise de Freud sobre Macbeth, Sinfield lembra que para Freud, “a esterilidade está por trás de tudo. Ele ressalta que a rainha Elizabeth foi obrigada a reconhecer James VI da Escócia como seu herdeiro porque ela, assim como Lady Macbeth, não gerou herdeiros diretos, e que James era o filho de Mary Stuart, cuja execução foi ordenada por Elizabeth. [...] Conforme Freud reflete, a incapacidade de gerar a prole poderia explicar a eventual transformação de Macbeth em um tirano sedento por sangue" ${ }^{329}$. Neste ponto, a utilização da ópera no filme, cuja entrada é feita logo após a cena em que Chloe e Chris anunciam à família a chegada do herdeiro, aproxima Chris de Macbeth e Chloe de Lady Macbeth. Vale lembrar que apenas

\footnotetext{
${ }^{327}$ O britânico Bansky é considerado o grafiteiro mais famoso do mundo. Em 2009, houve uma exposição de seus trabalhos no Bristol City Museum que causou muita polêmica. O stencil, retratado em Match Point, é conhecido como "garota-com-o-balão-de-coração graff-pic". Os grafites de Bansky são conhecidos por retratarem "a atmosfera de negligência e decadência social, que por sua vez estimula o crime [...] O trabalho de Bansky, assim como todos os grafites bons, dá aos indivíduos e aos coletivos uma identidade em face à cultura consumista e homogeneizante. Ele reivindica os espaços ocupados pelas grandes corporações. [...] Em resumo, é sobre uma luta." Disponível em: <http://www.guardian.co.uk/commentisfree/2007/apr/24/stayingunderground $>$. Acesso em: 13 mar. 2010.

${ }^{328}$ O figli, o figli miei! da quel tiranno

Tutti uccisi voi foste, e insieme con voi

La madre sventurata!... Ah, fra gli artigli

Di quel tigre io lasciai la madre e i figli?

Ah, la paterna mano..."

${ }^{329}$ Sinfield, op.cit., p.55.
} 
depois do "projeto de fertilização" e da execução de Nola e da Sra. Eastby que o filho foi concebido. Conforme argumenta Sinfield, "o personagem Macbeth não é uma misteriosa essência natural. Ao contrário, ele está situado no cruzamento entre discursos e forças históricas que estão em competindo, poderíamos dizer, para completar a sua subjetividade. No começo, ele está representando a história dominante - matando traidores para o regime atual." ${ }^{330}$ Desse modo, ao incluir a ópera Macbeth, o filme estabelece a comparação entre a história do personagem shakespeareano e a trajetória de Chris que, assim como Macbeth, comete os crimes restabelecendo a ordem dominante.

No entanto, na ópera, a ária é interrompida pela chegada do exército de libertação comandado por Malcolm ${ }^{331}$. Para Kobbé, neste ponto da ópera, "a força que aqui se opõe à tirania de Macbeth não é apenas a retaliação, mas outra menos trágica e mais circunstancial: o patriotismo, subjacente por todo o tempo e personificado em Macduff, Banquo, no coro e, naturalmente, na figura menos destacada de Malcolm"332. Por se tratar de um irlandês, que atravessou o rio para chegar a Londres, e que joga a aliança no rio Tâmisa, poder-se-ia pensar que assim como Macduff, Banquo e Malcolm, Chris estaria arremessando a aliança à revelia da família Hewett, em um ato de resistência contra os representantes do império britânico. Todavia, a ironia da cena está em apresentar o irlandês, ao som da ópera sobre o levante escocês, livrando-se das provas do crime em nome do império. A cena pode ser entendida também como um comentário de Allen sobre a ópera, no qual o levante comandado por Malcolm não traz a liberdade do povo escocês, mas reinstala a ordem. Conforme argumenta Sinfield, "Macbeth não pode ser coroado como um monarca de fato porque isso faria problemática a sua derrubada. A ideologia jamesiana assegurava que nenhum governante estabelecido deve ser contestado; e por respeito a isso, faz-se acreditar que Macbeth dificilmente tornar-se-á rei - guerreiros importantes não juram fidelidade em sua coroação e sua tentativa de realizar um banquete de estado é um fiasco; sua remoção ocorre em uma fase de incerteza e instabilidade geral ${ }^{, 333}$.

Em Match Point, o protagonista dirige-se ao rio Tâmisa no intuito de livrar-se das provas do crime, por isso arremessa os pertences da Sra. Eastby no rio. Revirando os bolsos, olha para a câmera e atira o restante dos objetos da vítima ao rio. Nesse momento, a copa das

\footnotetext{
${ }^{330}$ Ibid, p.63.

${ }^{331}$ Kobbé, op.cit., p.309.

${ }^{332}$ Ibid, p.311.

${ }^{333}$ Sinfield, op.cit., p.55-56.
} 
árvores confere certa escuridão à cena e Chris arremessa o último pertence, a aliança da Sra. Eastby. Em câmera lenta, acompanhamos o movimento da joia: a aliança bate na grade, fica por um breve momento suspensa no ar - onde se pode observar o Swiss Re ao fundo - , e cai para o lado do protagonista.

A cena estabelece paralelo com a abertura do filme na qual em câmera lenta observase o percurso de uma bolinha de tênis ao passo que o protagonista expõe os "pressupostos filosóficos" da obra. Quando a bolinha bate no topo da rede, o narrador afirma que "se ela cair para o seu lado você perde, mas talvez ela não caia e você ganhe". Portanto, no momento em que a aliança arremessada pelo protagonista não cai no rio, o espectador conclui que o assassino será condenado.

No entanto, trata-se de uma armadilha: mesmo sem ter conseguido arremessar todos os pertences da vítima, o assassino não será condenado. Além da imagem do Gherkin ao fundo, relacionando o crime às finanças: da referência extra-diegética à ópera Macbeth, que retoma a ideia do tirano sanguinário como enviado da classe dominante e da importância da aliança entre o irlandês e a família Hewett, Allen retoma o romance Crime e castigo. Precisamente por contar com a aliança, o casamento com Chloe, Chris não será condenado como Raskólnikov. A composição da cena, feita por Allen, no momento em que Chris atira os pertences da vítima ao rio retoma a mesma situação descrita por Dostoiesvki:

Há muito já havia decidido: "Lançar tudo no canal, jogar as provas na água, e assunto encerrado". Assim havia decidido ainda na noite anterior, em delírio, nos instantes em que se lembrara disso, e algumas vezes tivera ímpetos de levantar-se e sair: "Rápido, rápido, jogar tudo fora". Mas acabou sendo muito difícil jogar as coisas fora.

Já fazia meia hora e talvez mais que perambulava pela marginal do canal de Iecaterina, e várias vezes examinara as descidas para ele, que iam até embaixo. Mas não dava nem para pensar em pôr a intenção em prática: ou havia balsas estacionadas à beira das próprias descidas e nelas lavadeiras lavavam roupa, ou barcos ali ancorados fervilhavam de gente em toda parte, ou de todos os pontos da marginal ele podia ser visto: era suspeito que um homem descesse de propósito, ficasse ali parado e atirasse coisas n'água. E vamos que os estojos não afundassem e saíssem flutuando? Evidentemente isso acabaria acontecendo. Qualquer um notaria. E ademais, todo mundo já o estava olhando de um jeito esquisito quando cruzava com ele, medindo-o com o olhar, como se nada mais lhe interessasse a não ser ele. "Por que isso, ou será impressão minha?" - pensava. ${ }^{334}$

\footnotetext{
${ }^{334}$ Dostoievski, op.cit., p.121-122.
} 
Raskólnikov acaba enterrando os pertences da velha usurária em um local ermo por medo de ser encontrado. Por sua vez, Chris pode arremessar as joias da Sra. Eastby em plena luz do dia em um local bastante frequentado por turistas, os arredores da ponte Queen's Walk, sem que nenhum transeunte o intercepte. No momento em que a aliança cai no chão, sem que o protagonista perceba, Allen corta para a delegacia de polícia, onde a ópera continua (“ $A h$, $l a$ paterna mano...") como uma espécie de voz recalcitrante rememorando o filho de Chris e Nola que foi morto pela mão paterna. Na delegacia, o inspetor de polícia e o protagonista caminham em direção à câmera. Ao encontrarem o detetive Banner, a ópera é interrompida.

Chris é apresentado ao detetive pelo inspetor de polícia. Banner explica ao protagonista que ele não precisa preocupar-se: "Nós só estamos fazendo um procedimento habitual na investigação dos assassinatos de Betty Eastby e Nola Rice". Enquanto o detetive interroga-o, observa-se a reação do protagonista: "Você conhecia alguma das vítimas?" O executivo afirma que conhecia a Nola Rice, apenas "superficialmente".

A câmera volta para o detetive que parece não acreditar no relato de Chris. Ele pergunta qual foi a última vez em que se viram e Chris finge não lembrar a data. O inspetor de polícia, sentado ao lado do suspeito, desconfia do protagonista e olha para o detetive. Banner pergunta a Chris se ele encontrou a vítima novamente, o protagonista sorri e afirma: "Não que eu me lembre."

Nesse momento, o detetive apresenta ao suspeito o diário de Nola. O inspetor de polícia dá um pequeno sorriso. O rosto de Chris volta ao centro da ação. Banner informa ao suspeito que existem muitas referências a ele no diário de Nola e repete a pergunta sobre a data do último encontro. Com a apresentação do diário, assim como a aliança, conclui-se que o protagonista será condenado. No entanto, o herói cheio de credenciais utiliza as prerrogativas de classe para justificar-se:

[Chris Wilton]: "Não pode me culpar por eu tentar esconder que tive um caso com ela. Mas, vocês têm que me proteger. Eu espero que vocês não pensem que eu tenha alguma relação com o assassinato dela."

[Detetive Banner]: "Por quanto tempo o caso durou?"

[Chris Wilton]: "Começou por acaso quando ela ainda estava noiva do Tom, eles terminaram, ela se mudou. Quando ela voltou, encontrei-a na Tate Modern e reatamos. Por favor, tenham compaixão. Minha esposa está grávida, isso vai acabar com ela."

[Detetive Banner]: "Você prometeu a ela que deixaria sua esposa e se casaria com a senhorita Rice?"

[Chris Wilton]: "Não, não prometi. É possível que ela tivesse essa fantasia e, então, claro que ela escreveu que eu prometi, mas eu tentei 
resolver esse ponto com ela. Eu não queria que a relação sexual acabasse, mas eu não vou destruir o meu lar. Minha esposa e eu estamos tentando muito ter um bebê, procuramos diversos médicos especialistas em reprodução etc. Vocês podem checar essa informação se quiserem, mas eu imploro que sejam discretos."

Neste momento, observa-se certa identificação entre o inspetor de polícia e o suspeito. Chris olha para Dowd, a câmera muda de posição e focaliza o inspetor de polícia que parece concordar com o suspeito. Diferentemente do detetive Banner, Dowd esteve no prédio de Nola e da Sra. Eastby. O inspetor de polícia já tem uma conclusão para o caso: "Um crime relacionado a drogas". Por sua vez, o detetive aparenta ser o guardião dos códigos de honra e da moralidade:

[Detetive Banner]: "Mas, você a iludiu e deu a impressão de que estava infeliz em casa."

[Chris Wilton]: "Eu tentei esclarecer a questão e não enganá-la, mas ela acreditava no que ela queria. Olha, não destruam os sentimentos das pessoas irresponsavelmente, arruinando suas vidas. Não existe nenhuma ocorrência, porque eu não machucaria ninguém, muito menos a Nola Rice."

Nesse momento, o protagonista olha para o inspetor de polícia, segura a cabeça e chora: "Não é óbvio que alguém matou a vizinha e ela apareceu quando isso estava acontecendo? Meu Deus, eu lhes imploro, não iniciem uma investigação sobre isso de maneira irresponsável, destruindo a vida das pessoas. Minha família, meu casamento estão em jogo." Chris pede aos policiais para que o ajudem a preservar a sua imagem perante a família e solicita para que a investigação seja mantida em segredo. O detetive concorda e explica os procedimentos da polícia:

[Detetive Banner]: "Nós só temos que checar todas as informações em um caso de assassinato."

[Chris Wilton]: "Ok. Mas, eu não sou quem você procura. Eu sei que não é a coisa mais honesta do mundo trair a esposa, mas isso não me faz um assassino".

[Detetive Banner]: "Somos obrigados a analisar a situação, entendo que é uma situação delicada para você e se tivermos de procurá-lo de novo, faremos tudo de forma privada. Sua vida pessoal é sua, não estamos fazendo julgamento moral, só investigando um crime".

Com as mãos no rosto, Chris pede para que caso a polícia tenha que contatá-lo novamente o faça por meio de seu telefone celular, ou seja, de forma privada e sem deixar 
indícios. O detetive agradece e faz uma última pergunta se Chris possui ou tem acesso a uma espingarda. Chris faz como quem não entende o que foi perguntado: "Eu?" O ex-tenista nega ter acesso a uma espingarda e explica que o sogro participa de competições de caça na casa de campo, mas ele não: "Você pode checar isso, mas eu imploro que vocês considerem a minha posição e a dele." Nesse ponto, Chris faz referência à sua posição social e a do sogro, membros da elite britânica, pedindo para que ela seja assegurada pela polícia. O detetive concorda com a solicitação: "É claro".

Após a saída de Chris, a conversa entre os dois detetives confirma a versão sugerida pelo protagonista: "Eu acho que é o que parece ser: alguém roubou e matou a Sra. Eastby, foi surpreendido quando saía e matou a Nola Rice." O detetive concorda com a opinião do inspetor: "É, eu sei, isso tem toda a cara de roubo relacionado a drogas." O inspetor de polícia entende a situação do protagonista que está sendo investigado apenas por conta da traição, tendo em vista que o caso já fora resolvido pelos outros policiais no local do crime:

[Inspetor Dowd]: "Ele está esperando um bebê. Tudo bem, ele não vai ganhar a medalha da fidelidade, mas nós podemos procurar discretamente se os Hewetts tem uma espingarda desaparecida. Eu não acho que ele saberia roubar nem serrar uma arma. Você precisa de um certo tempo de cadeia e ele não tem nenhuma condenação anterior, nem mesmo multa de trânsito por excesso de velocidade. O legista disse que Eastby foi morta antes, não há nenhum sinal de arrombamento."

[Detetive Banner]: "Então, a Sra. Eastby deveria conhecer o assassino se o deixou entrar."

[Inspetor Dowd]: "Por favor, Mike. Noventa por cento dos crimes que a gente investiga são de pessoas que abrem a porta e convidam os criminosos para entrar."

[Detetive Banner]: "Eu sei que você está certo, só estou pensando alto... Ele tem um motivo real."

[Inspetor Dowd]: "Sim, talvez, mas um motivo, como você e eu tristemente sabemos, não é uma ocorrência."

[Detetive Banner]: "Eu queria recompor os pedaços porque o assassinato da Nola Rice foi claramente pensado depois, mas eu adoraria ir atrás disso um pouco mais. Mas, estou apreensivo em investigar e causar problemas para todos."

[Inspetor Dowd]: "Se alguma coisa acontecer, nós podemos investigar, mas eu duvido que algo caia no nosso colo."

O sotaque cockney do detetive e do inspetor de polícia faz lembrar que são os membros da classe trabalhadora que fazem a segurança da elite britânica. O inspetor de polícia descarta a hipótese de Chris ser o criminoso, pois "você precisa de um certo tempo de cadeia" e "ele não tem nenhuma condenação anterior, nem mesmo multa de trânsito por 
excesso de velocidade”. Assassinatos como os da Sra. Eastby e o de Nola já estão previstos pelos policiais, são corriqueiros, acontecem diariamente nas ruas de Londres e chegam às delegacias de polícia: "Em noventa por cento dos crimes que investigamos, as pessoas abrem a porta e convidam os criminosos para entrar". Para os policiais, "o assassinato da Nola Rice foi claramente pensado depois". Por se tratar de um bairro violento, no qual são frequentes os crimes relacionados às drogas e os assassinatos a pessoas comuns, os policiais não prosseguem com a investigação contra o executivo. Se as vítimas fossem um dos Hewett, a situação certamente seria outra. A preocupação do detetive "em não causar problemas a todos" indica que a polícia, "à custa de preservar a honra da família"335 e considerando a posição dos homens de negócios, será discreta e evitará trazer problemas à elite britânica. Vemos esboçado no papel da polícia uma espécie de segurança privada, a privatização da polícia, aliada dos executivos e preservando as grandes corporações. Essa aliança entre o executivo e os policiais se faz na base do "acordo entre cavalheiros", o segredo que "protege de qualquer esclarecimento os bens acumulados dos possuidores",336.

\subsection{O sonho}

“Pois o sonho e o 'drama de estação’ coincidem de fato em sua estrutura: uma sequência de cenas, cuja unidade não é constituída pela ação, mas pelo eu do sonhador ou do herói, que permanece idêntico.”

Peter Szondi, Teoria do drama moderno [1880-1950].

“O espetáculo é o sonho mau da sociedade moderna aprisionada, que só expressa afinal o seu desejo de dormir.

O espetáculo é o guarda desse sonho". Guy Debord, A sociedade do espetáculo.

$\mathrm{Na}$ cena seguinte ao interrogatório na delegacia, observa-se um pequeno relógio despertador que indica tratar-se da madrugada. No quarto do casal no Parliament View Apartments, a herdeira dorme. Por sua vez, o protagonista permanece na sala do apartamento, em meio aos objetos de trabalho. Ele repousa em cima do computador, dos jornais, das anotações, relatórios e outros papéis de trabalho. A iluminação da cena é feita apenas por uma pequena luminária, como se houvesse um aspecto sombrio na residência do casal. A câmera

\footnotetext{
${ }^{335}$ Eisenstein, op.cit., p.101.

${ }^{336}$ Debord, op.cit., p.208.
} 
aproxima-se do executivo, ele parece acordar. Cansado pelo trabalho tedioso, Chris tenta escrever ao computador, a câmera foca nas mãos trêmulas do protagonista que começa a digitar. Ouve-se alguns ruídos no apartamento, ele olha para trás e volta a digitar. O protagonista ouve novamente os ruídos em seu apartamento. Há um close em seu rosto. A face de Chris revela cansaço e agonia. Chris derruba o copo de vinho tinto em cima de um dos papéis de trabalho. Ele coloca as mãos no rosto e chora. O protagonista olha para o computador e levanta-se em direção à cozinha. $\mathrm{O}$ cenário é tomado pela escuridão. $\mathrm{Na}$ cozinha, ele limpa o rosto e cobre a face com um papel toalha.

Por detrás da câmera, o fantasma de Nola aproxima-se do protagonista. Há pouca entrada de luz na cozinha, o que contribui para a atmosfera noir da cena. Assim como Chris fizera no momento em que atirou contra Nola, a norte-americana chama pelo protagonista. Ele vira o rosto em direção a ela e começa a se justificar: "Não foi fácil, mas quando chegou a hora, eu puxei o gatilho. Você nunca sabe quem são os seus vizinhos até que haja uma crise. Você aprende a empurrar a culpa para debaixo do tapete e continua. Você precisa, caso contrário ela te soterra." O close no rosto do protagonista revela, a despeito do discurso do personagem, a loucura, o desvario de Chris. Assim como nos quadros de Lucian Freud, a história parece estar marcada no rosto dos personagens: a senhora, a norte-americana, o irlandês.

Ouve-se a voz da Sra. Eastby: "E quanto a mim, a vizinha ao lado?" O protagonista vira o rosto em direção à ela.. A vizinha prossegue: "Eu não tinha nenhuma relação com esse caso terrível. Não há problema algum em eu ter que morrer como uma espectadora inocente?” A ideia de uma "espectadora inocente" faz lembrar as cenas, nas quais o patriarca e seu genro apontaram a arma para a câmera, retomando a ideia dos assassinatos contra inocentes.

Enquanto Chris explica o assassinato, vê-se o olhar da Sra. Eastby, marcado por pavor e sombras: "Os inocentes têm algumas vezes que morrer para abrir o caminho para um grandioso plano. Você foi um dano colateral." A expressão utilizada por Chris "collateral damage" faz lembrar a maneira pela qual as vítimas civis foram descritas na Guerra no Iraque. É sabido que norte-americanos e britânicos uniram-se no confronto que ocasionou a morte de milhares de civis. A aliança entre George W. Bush e Tony Blair na Guerra do Iraque provocou uma série de protestos na Inglaterra. Para a comentarista política Jackie Ashley, do Guardian: “A Guerra no Iraque destruiu a confiança de muitas pessoas na política. Destruiu muitas vidas, e isso é o mais importante. Mas entre os danos colaterais estava o Novo 
Trabalhismo em si. Ele morreu no Iraque. [...] A Guerra destruiu a política progressista na Grã-Bretanha para uma geração",337. A ideia de que uma geração foi perdida é retomada pelo filme: o filho de Chris e Nola é mais uma das vítimas inocentes que foram descritas como "danos colaterais". Com o rosto marcado pelo terror, a Sra. Eastby lembra a criança morta pelo pai: "Assim como foi o seu próprio filho".

A câmera retorna para Chris que engole o choro e compara o destino de seu filho ao de Édipo: “Sófocles disse: 'Nunca ter nascido pode ser a melhor dádiva de todas'. Nesse ponto, podemos retomar o sentido propriamente trágico em Match Point, conforme exposto por Raymond Williams: “A ação real incorpora o sentido particular, e tudo o que é geral nas obras a que chamamos tragédias é a dramatização de uma desordem específica e atroz, e a sua resolução." 338 Por sua vez, Nola retoma a possibilidade de punição: "Prepare-se para pagar o preço, Chris. As suas ações foram desajeitadas, cheias de furos. Quase como alguém que estivesse implorando para ser pego.” A fala de Nola reinsere a questão do criminoso inexperiente. A indicação de que Chris implora "para ser pego" é, por sua vez, retomada pelo protagonista: "Seria conveniente se eu fosse pego e punido, ao menos teria algum pequeno sinal de justiça, alguma pequena medida de esperança para a possibilidade de sentido."

$\mathrm{Na}$ cena do sonho do protagonista, o universo de sombras e o retorno dos fantasmas remetem à temática "expressionista” de Strindberg. Segundo Peter Szondi, "as personagens da trilogia Damasco (a dama, o mendigo, César) são irradiações do eu do Desconhecido, e segundo o qual a obra como um todo reside na subjetividade de seu herói. Mas essa contradição é o paradoxo da própria subjetividade potencializada em algo objetivo. Que o inconsciente depara com o eu consciente (isto é, o eu que se torna consciente de si) como um estranho é o que revela a psicanálise já em sua terminologia, nas qual o inconsciente se apresenta como id. Desse modo, o indivíduo isolado, que se refugia em si mesmo ante o mundo se tornou estranho, volta a se defrontar com o estranho" 339 .

Nesse ponto, retomaremos a hipótese de que o filme expõe a perspectiva subjetiva do protagonista, próxima ao universo do "drama de estação", criado por Strindberg. Conforme argumenta Raymond Williams, nas últimas peças de Strindberg: "O mundo do sonâmbulo, do sonhador, do forasteiro torna-se absoluto. O foco voltado para as relações específicas é

\footnotetext{
337 Disponível em: <http://www.guardian.co.uk/commentisfree/2010/jan/31/new-labour-iraq-destroyedprogressive>. Acesso em: 13 mar. 2010.

${ }^{338}$ Williams, op. cit., p.78.

339 Szondi, op.cit., p.62.
} 
abandonado, e em seu lugar surge uma consciência isolada. A luta humana, nesse extremo de dor, torna-se totalmente interna. As outras pessoas são simplesmente imagens no interior de uma agonia pessoal." 340 Esta agonia passa a retratar o cotidiano do protagonista em Match Point que transforma-se em um sonâmbulo. De acordo com Szondi, a dramaturgia subjetiva “corresponde menos à ideia de que só seria possível projetar a própria vida psíquica, já que apenas esta seria acessível, do que a intenção prévia de conferir realidade dramática à vida psíquica, a essa vida essencialmente oculta. O drama, a forma literária por excelência da abertura e franqueza dialógicas, recebe a tarefa de representar acontecimentos psíquicos ocultos. Ele a resolve ao se concentrar em seu personagem central, seja se restringindo a ele de modo geral (monodrama), seja apreendendo os outros a partir de sua perspectiva (dramaturgia do eu), com o que, no entanto, deixa de ser drama"341. Assim, argumenta Szondi, as peças de Strindberg caminham em direção ao épico. A "dramaturgia do eu”, composta por Strindberg, pode ser associada à técnica do monólogo interior, exposta por Eisenstein. Na cena do sonho, podemos observar o modo por meio do qual o cineasta russo gostaria que a adaptação de Uma tragédia americana fosse feita: "Como que apresentando dentro de personagens o jogo interior, o conflito de dúvidas, as explosões de paixão, a voz da razão, rapidamente ou em câmera lenta, marcando os ritmos diferenciados de um e outro e, ao mesmo tempo, contrastando com quase total falta de ação externa: um febril debate interior atrás da máscara petrificada do rosto." ${ }^{, 342} \mathrm{O}$ conflito interior, assim como foi feito no momento do assassinato por meio da utilização da ópera Otelo, pode ser visto pelo espectador, no rosto do personagem que dialoga com os fantasmas - projeções do próprio Chris - como quem narra um discurso pronto, alheio a si próprio, semelhante ao discurso de justificativa de guerra. Assim como Macbeth e Otelo, Chris está "representando a história dominante" 343 .

De forma abrupta, a cena do sonho é cortada para a residência do detetive. Assim como o protagonista, o detetive acorda do sonho, como se ele tivesse ouvido um recado dos mortos: "Chris Wilton matou-as. Eu vi como ele fez isso." A esposa de Banner acorda: "O que?" Há um elemento cômico na cena que pode ser percebido pela reação da esposa. Em seu domicílio, o detetive recebe a ajuda dos mortos para a resolução do crime. No entanto, trata-se

\footnotetext{
${ }^{340}$ Williams, op.cit., p.151.

${ }^{341}$ Szondi, op.cit., p.58.

${ }^{342}$ Eisenstein, op.cit., p.105.

${ }^{343}$ Sinfield, op.cit., p.63.
} 
de um sonho, a projeção subjetiva do policial, o qual imagina essa solução, porque quer descobrir o "seu grande caso" 344 , ganhar popularidade ao prender um membro da alta sociedade. Na delegacia, o detetive entusiasmado narra o sonho ao colega:

[Detetive Banner]: "Foi como nós suspeitávamos e que foi dito que era muito complicado, mas foi isso o que ele fez: ele matou a vizinha primeiro para nos despistar e para dar a impressão de um roubo. Ele esperou no corredor, sabia que ela chegaria no mesmo horário de sempre e ele a matou, fazendo parecer que ela surpreendeu um ladrão em fuga. Ele planejou tudo para que ele pudesse chegar ao teatro em tempo para fortalecer o seu álibi se necessário. Ainda não resolvi a questão da arma e eu sei que isso é muito para pedir ao júri, mas a certeza disso chegou a mim em um sonho e eu vou resolver esse caso."

[Inspetor de polícia Dowd]: "Detesto trazer más notícias, Mike. Não que o seu sonho não seja interessante para o júri. Mas, houve outro tiroteio na região na noite passada, às quatro da manhã, um viciado foi morto, parece que uma venda de drogas não deu certo."

[Detetive Banner]: "E o que, ele confessou ter matado as duas mulheres antes de morrer?"

[Inspetor de polícia Dowd]: "Não, ele não precisou. A aliança da senhora estava no seu bolso com o nome e data gravados."

Ambos os atores que representam os policiais são conhecidos pelo público inglês por representarem personagens em comédias, o que reforça a ironia da cena. Banner afirma não acreditar que a aliança da Sra. Eastby signifique o fechamento do caso. Por sua vez, Dowd continua a escarnecer o colega: "Eu sei, eu sei, o seu caso parecia bom, vários motivos. Mas, o motivo dele era bem forte também, heroína. Um viciado com uma longa história de condenações. Morto por um dos seus, sem dúvida. Vamos lá, eu pago o seu café da manhã, você pode me traumatizar com o resto dos seus sonhos."

Banner tenta ainda resolver o seu grande caso: "Não, mas e se o Wilton matou-as, se livrou das joias e este homem as encontrou?" Dowd caçoa o colega: "Eu não sei, veremos o que o sonho desta noite lhe diz. Tenho certeza de que o júri terá interesse. Vamos.” Banner desiste do caso. Por sua vez, Dowd comemora: "Eu sabia que não tinha sido o Wilton, ele é apenas outro pobre idiota que traiu a mulher. Quando vir as fotos da Nola Rice, você vai entender porquê.” Resignado, Banner conclui: "Que mundo. Estou certo?” Existe na caracterização da polícia, feita pelo filme, uma espécie de competição entre os policiais para a resolução do crime: os que estavam no local do crime e o detetive Banner. A rivalidade entre

\footnotetext{
${ }^{344}$ Allen repetirá o mesmo caso em Scoop [2006], no qual a jornalista, Sondra Pransky [Scarlett Johansson], recebe a ajuda dos mortos para desvendar os assassinatos cometidos por um membro da alta sociedade. A publicação da reportagem é "O grande furo" da carreira de Sondra.
} 
os policiais retoma a intriga política que estava por trás da condenação de Clyde Griffiths, em Uma tragédia americana.. Conforme argumenta Eisenstein, "como parte do background do julgamento, é indicado que o verdadeiro objetivo do julgamento e da acusação de Clyde, porém, não tem nenhuma relação com ele. O objetivo é apenas criar a popularidade necessária entre a população de fazendeiros do estado (Roberta era filha de um fazendeiro) e o Promotor Público do Distrito, Mason, a fim de que ele obtenha o apoio necessário para ser eleito juiz. A defesa pega um caso que sabia sem esperança ("na melhor das hipóteses, dez anos numa penitenciária"), também no campo da luta política. Pertencendo ao campo político oposto, seu objetivo principal é usar o máximo de influência para derrotar o ambicioso promotor. De um lado, como do outro, Clyde é apenas um meio para se chegar a um fim."345.

Nossa hipótese entende que o filme apresenta o desenvolvimento do protagonista: não se trata de um "destino inexorável”. Chris tem opções, conforme revela em conversa ao amigo Henry: ele pode ter outro emprego e romper com Chloe para ficar com Nola. No entanto, prefere ficar ao lado dos Hewett, acostumou-se "a um certo tipo de vida". A ideia da sorte faz parte do discurso dominante, do jogo probabilístico do capital financeiro, no qual as vítimas inocentes são descritas como "collateral damage", a ideia de que os acertos compensariam os milhares de civis mortos e torturados pela guerra.

$\mathrm{Na}$ última cena do filme, antes que os personagens entrem em cena, observamos o quadro do homem negro de olhos fechados, atribuído a Lucian Freud. Os objetos de decoração, o móvel, as luminárias, a escultura, os livros e os porta-retratos do casal contrastam com a pintura do rapaz com o semblante abatido. No apartamento de Chloe e Chris, o primeiro a entrar na residência é o patriarca. Alec comanda os passos da família: "Cuidado, cuidado, eu sempre tenho medo de que eles caiam, os bebês são tão delicados". Na fala do patriarca, evidencia-se a ideia do herdeiro como uma joia de família. Após Alec, a babá do herdeiro entra no apartamento. A cor da pele morena da empregada da família aproxima-a da imagem do homem negro, retratado na tela de Freud (Figura 16). Característica que, por sua vez, contrasta com a tonalidade de pele da família de brancos. A babá passa em frente ao quadro do homem negro, carregando o herdeiro. A fala do patriarca dirige-se à babá, os outros membros da família não recebem ordens.

O patriarca abre o champanhe, dá-se início aos comentários sobre os traços étnicos da criança: Heather diz que o bebê tem os olhos de Chloe, a matriarca afirma que o neto possui a

\footnotetext{
${ }^{345}$ Eisenstein, op.cit., p.101-102.
} 
cor da jovem herdeira. A babá permanece segurando a criança. Ela deixa-o no sofá e passa em frente à câmera. Nesse ponto, podemos lembrar a conversa no restaurante entre Chloe e a cunhada, na qual as duas afirmaram que a maternidade não prejudica o trabalho, por conta da ajuda dos empregados. Ao olhar para o filho, Chloe diz que a coloração dos bebês, em geral, muda o tempo todo. Tom considera que o sobrinho assemelha-se ao irlandês.

Em seguida aos comentários sobre os traços raciais do bebê, Tom pergunta ao cunhado se ele foi transferido para o escritório que antes pertencia ao Alan Sinclair. O protagonista confirma a informação. Tom chama seu ex-professor de tênis de "porco sortudo". O espectador lembrará que Alan era o chefe de Chris. Todavia, após o nascimento do herdeiro, o protagonista ocupa o posto do funcionário antigo da empresa. Neste ponto, evidencia-se, que Chris é promovido por conta do nascimento do filho. Há uma espécie de capitalização da maternidade delineada no filme.

Reunida em volta do bebê, a família admira o herdeiro. A matriarca serve o champanhe e o patriarca faz o brinde: "Ao Terence Elliot Wilton com pais como Chloe e Chris, essa criança será nobre em qualquer coisa que fizer”. Tom complementa o brinde: "Não me importa que ele seja nobre, eu só espero que ele seja sortudo." A matriarca considera a afirmação do filho "um lindo pensamento". Alec concorda, garantindo que o neto “provavelmente será sortudo." A sorte, portanto, torna-se parte do discurso dos Hewett. A inovação trazida pelo empreendedor, o discurso da sorte apresentado pelo protagonista no começo do filme, transforma-se em valor social: "Os valores a partir dos quais as pessoas orientam suas ações e dão sentido a suas vidas vêm sendo transformados e reorientados segundo uma lógica semelhante à aplicada a outras formas de capital: esse conjunto de habilidades, capacidades e destrezas passa a ser considerado como produto de investimentos prévios, que, como todo investimento, visa a obtenção de benefícios futuros" ${ }^{346}$ Chloe aposta dinheiro com o marido de que o próximo filho será uma menina.

Nesse ponto, a ópera de abertura do filme, O Elixir de Amor, é retomada. A ária "Uma furtiva lágrima", cantada por Caruso, encerra o filme rememorando Nola, como um canto fúnebre. $\mathrm{O}$ aspecto soturno e triste da ópera e a ideia do elixir contrastam com os comentários da família Hewett, repetidos em coro: "Nós estávamos apenas dizendo o quanto ele é lindo. Eu queria saber no que ele pensa... Aqui estamos. Ao Terence e a tudo o que cruzar por ele.”

\footnotetext{
${ }^{346}$ López-Ruiz, op.cit., p.26-27.
} 
O olhar da câmera permanece no protagonista que não participa do brinde. Chris continua olhando pela janela do Parliament View Apartments sem dizer uma palavra. 


\section{Considerações Finais}

Há um quadro de Lucian Freud que se chama "Dois irlandeses em W11", 1984/85 (Figura 17). Representa dois homens de negócios em um apartamento do distrito de Paddington, local que Freud habitou por trinta anos. Em primeiro plano, observa-se um senhor que olha resignadamente para o chão. Sua cabeça está inclinada para o lado e o seu rosto é caracterizado por uma profunda tristeza. Suas feições são marcadas pelo tempo e cobertas por uma atmosfera de melancolia e desesperança. A vestimenta do executivo está amassada e desconjuntada. A escuridão do terno parece relacionar-se ao olhar dos personagens. As pinceladas espessas podem ser vistas tanto no apartamento como na vestimenta, no rosto, e nas mãos destes homens. A cor cinza escuro, utilizada tanto no rosto, como no terno e nas mãos dos personagens indicam um processo de progressiva deterioração. Na mão direita, observa-se a aliança de ouro do patriarca. Mas é precisamente o rapaz que está atrás do patriarca que nos interessa. O executivo mais jovem se apoia com uma das mãos a poltrona onde o senhor está sentado, resignado. A outra mão esconde-se atrás do paletó. A mão que se encontra sobre poltrona parece trêmula e indica a relação de dependência, acentuada pela disposição dos personagens. O homem jovem está posicionado atrás do primeiro, como uma espécie de empregado, subordinado, ou agregado. O senhor é robusto e gordo. Este homem de idade repousa as duas mãos sobre a poltrona, como se reafirmasse seu poder, mas, assim como o jovem, igualmente aparenta prostração. Em contraposição ao senhor, o jovem executivo é magro e fino. Apesar de sua condição de dependente, ele parece ser o próximo na sucessão do senhor. Os olhos deste jovem são marcados pelo entorpecimento e a prostração. Os dois irlandeses compartilham a vestimenta de executivo, um parece ser o espelho do outro, o seu amanhã. O apartamento em que estão situados não contém móveis, apenas esta poltrona sobre a qual o mais velho está sentado. Trata-se do ateliê de Freud. Pode-se observar ao fundo, do lado esquerdo da tela, duas pequenas telas em que se vêem borrões, como se fossem a face dos dois personagens. Na parede do apartamento, observamos o movimento da pintura, as pinceladas saltam à vista formando manchas disformes. Da janela do apartamento observam-se os prédios residenciais típicos da paisagem londrina, nos arredores de Paddington. Entre eles, destaca-se, ao fundo, um edifício alto 
semelhante a um prédio de negócios. O céu da cidade apresenta o mesmo cinza que caracteriza o apartamento, as mãos, os rostos e as vestimentas dos personagens. Há um sentimento de depressão e um desencanto geral nos rostos e nos corpos destes homens.

A semelhança entre o olhar destes homens retratados por Freud e o olhar do protagonista ao final de Match Point não passa despercebida. A melancolia, a subordinação, o entorpecimento e a resignação são compartilhados por esses homens de negócios, os do quadro e o do filme. Se no cenário contemporâneo, os esportistas, executivos, médicos, artistas e professores, devem correr riscos, quase como "um sinônimo de vitalidade, de emoção, de possibilidade de crescimento, de quebra da rotina e de vida no limite" ${ }^{, 347}$, os personagens retratados por Freud são o seu avesso. Há nesta representação dos executivos, “o preço que devia suportar por ser membro da organização e, particularmente, por ter de se submeter aos ditados da ética social [...]: a neurose" ${ }^{\text {348 }}$. Lucian Freud, assim como o avô psicanalista, identifica nos indivíduos que retrata o "mal estar da civilização" e a depreciação da sexualidade.

O sentimento de claustrofobia de Chris no Swiss Re, a insônia no Parliament View, o tédio ao lado da esposa, o projeto de fertilização para a concepção do herdeiro, entre outros aspectos problematizam a trajetória do protagonista. O próprio Woody Allen avalia o destino de Chris em negativo: “Acho que ele não está exatamente adorando a situação em que se encontra. Está casado com uma mulher por quem não é apaixonado. É um genro que gosta da vida fácil, para a qual se casou, mas se sente claustrofóbico trabalhando no escritório. A esposa dele já anda dizendo que quer mais um filho. Ele não pensa no crime. Conseguiu o que queria e pagou o preço por isso. É uma vergonha que ele queira isso. Posso ver, mais adiante, que não vai ficar contente nesse casamento, e talvez venha a ter uma base financeira tão boa que acabe por abandoná-la." ${ }^{\text {„49 }}$ No contexto das grandes corporações e do retrato do espírito do capitalismo contemporâneo, López-Ruiz argumenta que "estamos frente a um indivíduo paradoxalmente independente, mas não autônomo. Um indivíduo que trabalha para garantir os meios econômicos suficientes para manter a sua independência, mas que não vive segundo uma norma própria. É um sujeito dependente de valores e normas que ele não postula aceitar. Talvez seja válida então a hipótese de que o ethos social que os executivos das grandes

\footnotetext{
${ }^{347}$ López-Ruiz, op.cit., p. 237.

${ }^{348}$ Ibid., p. 149.

${ }^{349}$ Lax, op.cit., p. 174.
} 
corporações emblematizam pode ser caracterizado como uma forma de individualismo sem sujeito, vivendo em uma situação de independência sem autonomia."350

${ }^{350}$ López-Ruiz, op.cit., p.73. 


\section{BIBLIOGRAFIA}

\section{Livros sobre Woody Allen}

BEACH, Christopher. Is there a class in this text? Woody Allen and Postmodern Comedy. In:

Class, Language, and American Film Comedy. Cambridge: Cambridge University Press, 2002.

BJÖRKMAN, Stig. Woody Allen on Woody Allen. New York: Grove Press, 2002.

DELEYTO, Celestino. The Narrator and the Narrative: The Evolution of Woody Allen's Film Comedies". In: SILET, Charles (ed.). The Films of Woody Allen: critical essays. Oxford: The Scarecrow Press, 2006.

GIRGUS, Sam. The Films of Woody Allen. 2.ed. Cambridge: Cambridge University Press, 2002.

LAX, Eric. Conversas com Woody Allen: seus filmes, o cinema e a filmagem. São Paulo: Cosac Naify, 2008.

LEE, Sander. Eighteen Woody Allen Films Analyzed: Anguish, God and Existentialism. McFarland \& Company, 2002.

MARTINS, Luiz Renato. Woody Allen: entre a lírica e a política. In: Novos Estudos CEBRAP, Nº38, 3/1994.

MORRIS, Christopher. Woody Allen's Comic Irony. In: SILET, Charles (ed.). The Films of Woody Allen: critical essays. Oxford: The Scarecrow Press, 2006.

SCHATZ, Thomas. Annie Hall and the Issue of Modernism. In: SILET, Charles (ed.). The Films of Woody Allen: critical essays. Oxford: The Scarecrow Press, 2006. 
SILET, Charles (ed.). The Films of Woody Allen: critical essays. Oxford: The Scarecrow Press, 2006.

STAM, Robert; SHOHAT, Ella. Zelig. In: LABAKI, Amir (Org.) O Cinema dos anos 80. São Paulo: Brasiliense, 1991.

\section{Romances}

ASSIS, Machado de. Dom Casmurro. In: Obras Completas - vol.1. Rio de Janeiro: Nova Fronteira, 2004.

DOSTOIEVSKI, Fiódor. Crime e castigo. Tradução de Paulo Bezerra. São Paulo: Editora 34, 2001.

DREISER, Theodore. An american tragedy. New York: Signet Classic, 2000.

STENDHAL. O vermelho e o negro. Trad. Raquel Prado. São Paulo: Cosac Naify, 2003.

STRINDBERG, August. Miss Julie and other plays. Trad. Michael Robinson. Oxford: Oxford World's Classics, 1998.

\section{Obras teóricas}

ADORNO, Theodor; HORKHEIMER, Max. A indústria cultural. In: Dialética do esclarecimento: fragmentos filosóficos. Rio de Janeiro: Jorge Zahar Editor, 1985.

ARANTES, Pedro. O grau zero da arquitetura na era financeira. In: Novos Estudos CEBRAP, nº 80. São Paulo: mar. 2008.

BAUDELAIRE, Charles. As flores do mal. Tradução e notas de Ivan Junqueira. Rio de Janeiro: Nova Fronteira, 2006.

BAZIN, André. O cinema. Trad. Eloísa de Araújo Ribeiro. São Paulo: Brasiliense, 1991. 
BENJAMIN, Walter. Charles Baudelaire um lírico no auge do capitalismo. São Paulo: Brasiliense, 1989.

BRECHT, Bertolt (1898-1956). Brecht on film and radio. Londres: Methuen, 2000.

Brecht on theatre: the development of an aesthetic. trad. e edit. John Willett. Nova Iorque: Hill and Wang, 1977.

BOOTH, Wayne C. The rhetoric of fiction. Chicago: The University of Chicago Press, 1961.

BORDWELL, David. Narration in the fiction film. Madison: University of Wisconsin Press, 1986.

BRANIGAN, Edward. Point of view in the cinema. Nova Iorque: Mouton, 1984.

CALDWELL, Helen. Otelo brasileiro de Machado de Assis: um estudo de Dom Casmurro. Trad. Fábio Fonseca de Melo. São Paulo: Ateliê Editorial, 2008.

CANDIDO, Antonio (org.). A personagem de ficção. São Paulo: Perspectiva, 1968.

CLÉMENT, Catherine. A ópera ou a derrota das mulheres. Rio de Janeiro: Rocco, 1993.

DEBORD, Guy. A Sociedade do Espetáculo. Trad. Estela dos Santos Abreu. Rio de Janeiro: Contraponto, 1997. 
DONIZETTI, Gaetano. O Elixir de Amor. Trad. Manuel Rosa. Lisboa: Série Óperas Imortais, Editorial Notícias, 198?.

EAGLETON, Terry. Heathcliff and the Great Hunger - Studies in Irish Culture. Londres: Verso, 1995.

The English Novel: an introduction. Oxford: Blackwell Publishing, 2005.

EISENSTEIN, Sergei. A forma do filme. Trad.Teresa Otoni. Rio de Janeiro: Jorge Zahar Ed., 2002.

ENGELS, Friedrich. A situação da classe trabalhadora na Inglaterra. Trad. Rosa Camargo Artigas, Reginaldo Forti. São Paulo: Global, 1985.

FREUD, Lucian, Dois irlandeses em W11, 1984/85. In: SMEE, Sebastian. Lucian Freud. Trad. Isabel Falcão (Vernáculo Ltda., Lisboa). Taschen: 2008,

HAZELKORN, Ellen; PATTERSON, Henry. The new politics of the Irish Republic. In: New Left Review I/207, September-October, 1994.

KOBBÉ, Gustave. O livro completo da ópera. Rio de Janeiro: Jorge Zahar Ed., 1997. 
LÓPEZ-RUIZ, Osvaldo Javier. Os executivos das transnacionais e o espírito do capitalismo. Capital humano e empreendedorismo como valores sociais. Rio de Janeiro: Azougue Editorial, 2007.

LUKÁCS, Georg. Dostoievski. In: Ensaios sobre literatura. Rio de Janeiro: Civilização Brasileira, 1965.

MULVEY, Laura. Prazer visual e cinema narrativo. In: XAVIER, Ismail (org.). A experiência do cinema: antologia / Rio de Janeiro: Edições Graal: Embrafilmes, 1983.

ROSENFELD, Anatol. O teatro épico. São Paulo: Perspectiva, 2002.

SCHWARZ, R. A poesia envenenada de Dom Casmurro. In: Duas Meninas. São Paulo: Companhia das Letras, 1997.

As ideias fora do lugar. In: Ao vencedor as batatas. São Paulo: Duas Cidades, 1992.

Dinheiro, memória, beleza (O pai Goriot). In: A sereia e o desconfiado. São Paulo: Paz e Terra, 1981.

SIMMEL, Georg. The philosophy of money. Trad. Tom Bottomore e David Frisby. Londres: Routledge, 1991. 
SINFIELD, Alan. Cultural materialism, Othello, and the politics of plausability. In:

Faultlines: cultural materialism and the politics of dissent teading. Berkeley: University of California Press, 1992.

SMEE, Sebastian. Lucian Freud. Trad. Isabel Falcão. Taschen: 2008.

SOARES, Marcos. O projeto inacabado de Cidadão Kane. In: ; CEVASCO, Maria

Elisa (orgs.). Crítica cultural materialista. São Paulo: Humanitas, 2008.

SZONDI, Peter. Teoria do drama moderno: 1880-1950. São Paulo: Cosac Naify, 2001.

XAVIER, Ismail. O discurso cinematográfico: a opacidade e a transparência. São Paulo: Paz e Terra, 1977.

. O Olhar e a cena: melodrama, Hollywood, Cinema Novo. São Paulo: Cosac Naify, 2003.

. O olhar e a voz: a narração multifocal do cinema e a cifra da História em São Bernardo. In: Literatura e Sociedade: Revista de Teoria Literária e Literatura Comparada. São Paulo, n.2, 1997.

WILLIAMS, Raymond. Tragédia Moderna. São Paulo: Cosac Naify, 2002.

O campo e a cidade: na história e na literatura. Trad. Paulo Henriques Britto. São Paulo: Companhia das Letras, 1989. 
WILLIS, Susan. Evidências do real: os Estados Unidos pós-11 de setembro. São Paulo: Boitempo, 2008.

WU, Chin-Tao. Privatização da cultura: a intervenção corporativa nas artes desde os anos 1980. Trad. Paulo Cezar Castanheira. São Paulo: Boitempo, 2006.

\section{Dicionários Online}

HOUAISS ONLINE. Disponível em:<http://houaiss.uol.com.br/>. Acesso em: 8 jun. 2010.

LONGMAN ONLINE. Disponível em: 〈http://www.ldoceonline.com/dictionary/>. Acesso em: 8 jun. 2010.

MERRIAM-WEBSTER. Disponível em:<http://www.merriam-webster.com/>. Acesso em: 8 jun. 2010.

\section{$\underline{\text { Óperas e libretos }}$}

BIZET, Georges. I pescatori di perle. (ária Mi par d'udir ancora). Libreto de Carré e Cormon. Performance de Enrico Caruso (tenor). In: Match Point Soundtrack. Milan Records: Nova Iorque, 2005.

GOMES, Antonio Carlos. Salvatore Rosa (ária Mia piccirella). Libreto de Antonio Ghislanzoni, extraído do romance Massanielo, de Mirecourt. Performance de Enrico Caruso (tenor). In: Match Point Soundtrack. 49 min. Milan Records: Nova Iorque, 2005.

ROSSINI, Gioacchino. Guillaume Tell (ária Arresta...Quali sguardi). Libreto de V. J. Etienne de Jouy e H. L. F. Bis, com base na obra de Friedrich Schiller. Slovak Radio Symphony Orchestra. Performance de Janez Lotric (tenor), Igor Mozorov (barítono), 
Johannes Wildner (maestro). In: Match Point Soundtrack. 49 min. Milan Records: Nova Iorque, 2005.

VERDI, Giuseppe. La Traviata (ária Um di, Felice). Libreto de Francesco Maria Piave, com base na peça La Dame aux Camélias, de Alexandre Dumas. Slovak Radio Symphony Orchestra and Chorus. Performance de Monika Kraus, (soprano), Georg Tichy (barítono), Alexander Rahbari (maestro). In: Match Point Soundtrack. 49 min. Milan Records: Nova Iorque, 2005.

Il Trovatore (ária Mal reggendo all'aspro assalto). Libreto de Salvatore Cammarano, com base no drama homônimo de Antonio Garcia Gutierrez. Performance de Enrico Caruso (cantor). In: Match Point Soundtrack. 49 min. Milan Records: Nova Iorque, 2005.

Rigoletto (ária Gualtier Maldé!... Caro nome). Libreto de Francesco Maria Piave, com base em Le Roi s'Amuse, de Victor Hugo. Slovak Radio Symphony Orchestra and Chorus. Performance de Alida Ferrarini (soprano) e, Alexander Rahbari (maestro). In: Match Point Soundtrack. 49 min. Milan Records: Nova Iorque, 2005.

Otello. (ária Desdemona rea, si, per ciel). Libreto de Arrigo Boito, com base na peça de Shakespeare. Slovak Radio Symphony Orchestra. Performance de Janez Lotric (tenor), Igor Mozorov (barítono) e Johannes Wildner (maestro). In: Match Point Soundtrack. 49 min. Milan Records: Nova Iorque, 2005.

MacBeth. (ária O figli, o figli miei!). Libreto de Francesco Maria Piave, com base na peça de Shakespeare. Performance de Enrico Caruso. In: Match Point Soundtrack. 49 min. Milan Records: Nova Iorque, 2005. 


\section{$\underline{\text { Sites }}$}

ALL INFO ABOUT LONDON. "London's Gherkin Wins Top Architecture Prize". Disponível em: <http://london.allinfo-about.com/features/Swiss Re.html > . Acesso em: 13 jan. 2010.

ASHLEY, Jackie. "Here lies New Labour - the party that died in Iraq". In: Guardian. 31 jan. 2010. Disponível em: <http://www.guardian.co.uk/commentisfree/2010/jan/31/new-labouriraq-destroyed-progressive> . Acesso em: 13 mar. 2010.

ASPREY the beginning. Disponível em: 〈http://www.asprey.com/heritage/>. Acesso em: 13 mar.2010.

ATP WORLD TOUR. Andre Agassi. Disponível em:

$<$ http://www.atpworldtour.com/Tennis/Players/Ag/A/Andre-Agassi.aspx?t=tf $>$. Acesso em: 13 jan. 2010.

Tim Henman. Disponível em:

$<$ http://www.atpworldtour.com/Tennis/Players/He/T/Tim-Henman.aspx?t=tf $>$. Acesso em: 13 jan.2010.

THE BALTIC EXCHANGE. History: 1949 - Today. Disponível em: $<$ http://www.balticexchange.com/default.asp?action=article\&ID=395 $>$. Acesso em: 13 jan. 2010 .

BERTHOUD, Josh Freedman. "Staying underground". In: Guardian. 24 abr. 2007. Disponível em: <http://www.guardian.co.uk/commentisfree/2007/apr/24/stayingunderground $>$. Acesso em: 13 mar. 2010. 
BRANTLEY, Ben. A tutor, a triangle and hearts that sing. In: The New York Times. 18 nov. 2005. Disponível em: 〈http://theater.nytimes.com/2005/11/18/theater/reviews/18woma.html〉. Acesso em: 16 jun.2010.

BROWN, Mark. Koons floral sculputure sold for Record £ 12.9m. In: Guardian. 1 jul. 2008. Disponível em: 〈http://www.guardian.co.uk/artanddesign/2008/jul/01/art2>. Acesso em: 13 mar. 2010.

BRUTON STREET, BOND STREET AND DISTRICT ART GALLERIES. Sotheby's (Bond Street)". Disponível em: $<$ http://www.galleries.co.uk/g-nbs.htm $>$. Acesso em: 13 jan. 2010.

CAMERON, Colin. The London of "Match Point". In: The New York Times. 7 fev. 2006. Disponível em: <http://travel2.nytimes.com/2006/02/07/travel/08weblondon.html>. Acesso em: 13 jan.2010.

CROOT, Patricia. Royal Court Theatre. In: Social history: social and cultural activites. A History of the County of Middlesex. p.166-176. Disponível em: <http://www.britishhistory.ac.uk/report.aspx?compid=28709\#s9> . Acesso em: 3 mar. 2010.

CURZON MAYFAIR. History. Disponível em: <http://www.curzoncinemas.com/venues/mayfair/history>. Acesso em: 13 jan. 2010.

DUNLAP, David. A first look at Freedom Tower's neighbors. In: The New York Times. 8 set. $2006 . \quad$ Disponível em: $<$ http://www.nytimes.com/2006/09/08/nyregion/08towers.html?pagewanted=2\&sq=norman \% 20foster\%20and\%20World\%20Trade\%20Center \&st=cse\&scp=7>. Acesso em: 1 fev. 2010.

ENGELS, Friedrich. Engels to Marx - September 27, 1869. In: Marx-Engels Correspondence 1869. Marx and Engles on Ireland, Progress Publishers, 1971; transc. Andy Blunden. Disponível em: 
<http://www.marxists.org/archive/marx/works/1869/letters/69_09_27.htm>. Acesso em: 7 jul.2010.

ENGLEFIELD. St. Mark's Church. Royal Berkshire History. Disponível em: 〈http://www.berkshirehistory.com/churches/englefield.html> . Acesso em: 13 jan.2010.

ENGLEFIELD ESTATE. Disponível em: 〈http://www.englefieldestate.co.uk/>. Acesso em: 6 jun. 2009.

Country House of Berkshire: Englefield House. In: Britannia. Disponível em: $<$ http://www.britannia.com/history/chouses/berks/englefieldhse.html $>$. Acesso em: 13 jan, 2010.

FILM LONDON. Match Point. Disponível em: 〈http://filmlondon.org.uk/film_culture/film_tourism/movie_maps/match_point $>$. Acesso em: 13 jan, 2010.

FOSTER AND PARTNERS. Projects-Swiss Re. Disponível em: http://www.fosterandpartners.com/Projects/1004/Default.aspx acesso em 06.06.2009.

FRENCH, Philip. Match Point. In: The Observer. 8 jan. 2006. Disponível em: <http://www.guardian.co.uk/film/2006/jan/08/review.features7>. Acesso em: 13 jan. 2010.

. "Steel superstructure starts on Swiss Re London headquarters". Disponível em: 〈http://www.fosterandpartners.com/News/052/Default.aspx >. Acesso em: 13 jan.2010.

JOHNSON, Ben. The Benyon family say goodbye to the film-crew after a month of filming and stir in the village. In: The Newbury Today. 13 fev. 2008. Disponível em: 
〈http://www.newburytoday.co.uk/News/Article.aspx?articleID=6234>. Acesso em: 13 jan.2010.

LANE, Megan. Modern Britain's instant icon. In: BBC News Online Magazine. mar. 2004. Disponível em: 〈http://news.bbc.co.uk/2/hi/uk_news/magazine/3663971.stm>. Acesso em: 06 jun. 2009.

LUCY JONES. Disponível em: <www.momentumpublishing.co.uk/web_jones.jpg>. Acesso em: 1 mar.2010.

Lucy Jones - Palace of Westminster, 1999. In: Contemporary British art prints.

Disponível em: <http://www.art2invest.co.uk/pop-up_images/Palace_of_Westminster.htm>. Acesso em: 12 mar.2010.

MATLOFF, Jason. Woody Allen Speaks!. In: Premiere. Disponível em: $<$ http://www.premiere.com/article.asp?section_id=6\&article_id=2539 $>$. Acesso em: 13 mar. 2010.

MCDONALD, Henry. Sinn Féin can work with Tories, says Martin McGuinness. In: Guardian. 17 fev. 2010.2 Disponível <http://www.guardian.co.uk/politics/2010/feb/17/martin-mcguinness-sinn-feinconservativeshttp://www.guardian.co.uk/world/2009/aug/26/edward-kennedy-northernireland>. Acesso em: 20 mar. 2010.

Ted Kennedy helped Northern Ireland toward peace. In: Guardian. 26 ago. 2009. Disponível em: <http://www.guardian.co.uk/world/2009/aug/26/edward-kennedy-northernireland >. Acesso em: 13 jan.2010. 
; BOWCOTT, Owen. Bloody Sunday report: 38 years on, justice at last. In: Guardian. 15 jun. 2010. Disponível em: <http://www.guardian.co.uk/uk/2010/jun/15/bloodysunday-report-soldiers-prosecuted>. Acesso em: 16 jun.2010.

METROPOLITAN POLICE. History of the Metropolitan Police. In: Metropolitan Police. Disponível em: 〈http://www.met.police.uk/history/definition.htm>. Acesso em: 13 mar.2010

OWEN, Glen. Two-mortgages Prezza: how credit crunch will lose John Prescott $£ 200,000$ on luxury London flat. In: The Daily Mail. 8 nov. 2008. Disponível em: < $\underline{\text { http://www.dailymail.co.uk/news/article-1084174/Two-mortgages-Prezza-How-credit- }}$ crunch-lose-John-Prescott-200-000-luxury-London-flat.html>. Acesso em: 13 jan. 2010.

POGREBIN, Robin. British architect to redesign City Library. In: The New York Times. 22 out. 2008. Disponível em: 〈http://www.nytimes.com/2008/10/23/arts/design/23libr.html>. Acesso em: 1 fev. 2010.

QUEEN'S TENNIS CLUB. Disponível em: <http://www.queensclub.co.uk/site/_index_nonmember.htm>. Acesso em: 6 jun. 2009.

SCOTT, A. O. London Calling, With Luck, Lust and Ambition. In: The New York Times. 28 dez. 2005.2 Disponível em: <http://movies2.nytimes.com/2005/12/28/movies/28matc.html?ex=1165122000\&en=f64b1c3 ba6aceaa1\&ei=5070>. Acesso em: 6 jun.2009.

SWISSRE. Disponível em: 〈http://www.swissre.com/> Acesso em: 06 jun. 2009.

Swiss Re HQ, 30 St. Mary Axe. Disponível em: <http://www.fosterandpartners.com/Projects/1004/Default.aspx $>$ Acesso em: 1 fev. 2010. 
<http://www.swissre.com/pws/about\%20us/swiss\%20re\%20at\%20a\%20glance/swiss\%20re\% 20at\%20a\%20glance.html>. Acesso em: 1 fev. 2010.

Disponível em: 〈http://www.buildingtheSwiss Re.com/pdf/factsandfigures.pdf $>$. Acesso em: 13 jan.2010.

ROYAL OPERA HOUSE. Our History. Disponível em: <http://www.roh.org.uk/discover/royaloperahouse/history.aspx >. Acesso em: 6 jun. 2009.

TATE. The Building. Disponível em: <http://www.tate.org.uk/modern/building/>.Acesso em: 3 fev. 2010.

Albany Flats 1977-9. In: The Tate Gallery 1978-80: Illustrated Catalogue of Acquisitions, London $1981 . \quad$ Disponível em: <http://www.tate.org.uk/servlet/ViewWork? cgroupid=999999961\&workid=5963\&searchid=1 0870\&tabview=text>. Acesso em: 13 fev.2009.

What is St. Ives Art?. In: History of Art in St. Ives. Disponível em: <http://www.tate.org.uk/stives/art-in-stives/>. Acesso em: 3 fev.2010.

. The [dismantled] Baltic Exchange - In a location to suit you. Disponível em: <http://www.heritage.co.uk/apavilions/baltic.html>. Acesso em: 13 jan. 2010. 
VISIT BRITAIN. VisitBritain invites travelers to see the seductive sights that are featured in Woody Allen's latest film shot in England. Visit Britain. Disponível em: <http://www.visitbritain.us/press/news/news-releases/2005/nr051209match-point.aspx $>$.

Acesso em: 13 jan. 2010.

WILKIE COLLINS. The Woman in White. Disponível em: <http://www.wilkiecollins.info/books_woman_white.htm\#Plot>. Acesso em: 16 jun.2010.

THE WORLD GUIDE TO MOVIE LOCATIONS. Match Point film locations. Film locations: London. Disponível em: locations.com/movies/m/matchpoint_02.html>. Acesso em: 6 jun.2009.

WRIGHT, Stephen. The final insult: how family of innocent Brazilian shot dead on Tube will get just a fraction of $£$ 400k pay-off for blundering Met boss Blair. In: Daily Mail. 23 nov. 2009. Disponível em: <http://www.dailymail.co.uk/news/article-1230067/Jean-CharlesMenezes-Family-Brazilian-shot-dead-tube-just-fraction-400k-pay-blundering-Met-bossBlair.html>. Acesso em: 13 mar. 2010.

\section{Ficha técnica}

Match Point [2005]

Direção e roteiro: Woody Allen

Produção: Letty Aronson, Lucy Darwin, Stephen Tenenbaum, Gareth Wiley

Distribuição: Dream Works Pictures, BBC Films, Thema Productions SA.

Produção: Jada Production

Elenco: Brian Cox, Emily Mortimer, Jonathan Rhys-Meyers, Matthew Goode, Penelope Wilton, Scarlett Johansson.

Assistente de Elenco: Juliet Taylor, Gail Stevens.

Diretor de fotografia: Remi Adefarasin

Edição: Alisa Lepselter

Produção Musical: Milan Executive Album Producers, Emmanuel Chamboredon e Ian Hierons

Coordenador Trilha Sonora: Cindi Smith

Duração: 124 min. 
Ano: 2005

Locação: Ealing Studios, Londres, Reino Unido. 


\section{Anexos}

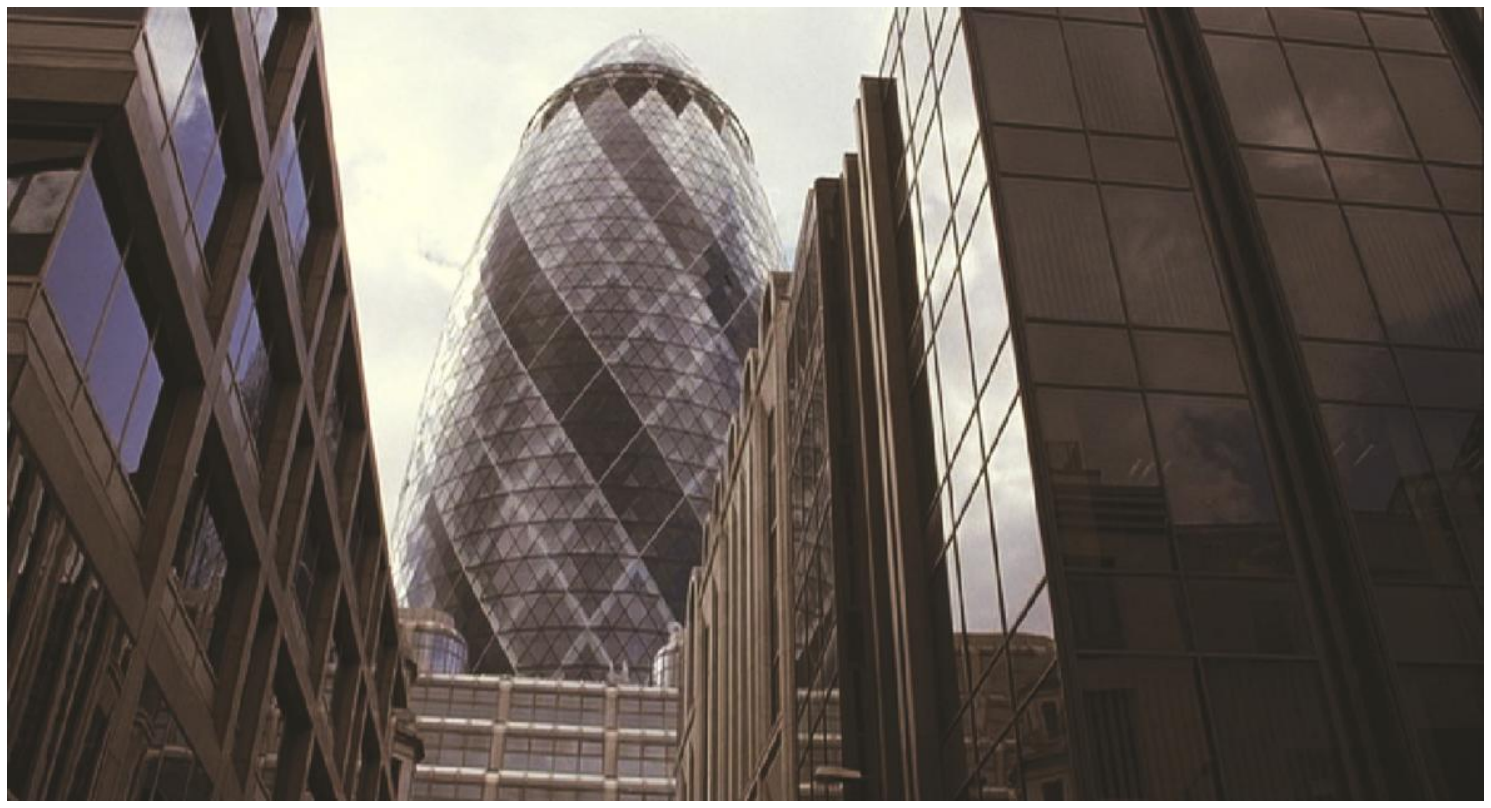

Figura 1: Swiss Re. Edifício na City, projetado pelo arquiteto Norman Foster. Cena que antecede a primeira visita de Chris a empresa da família Hewett para a sua entrevista de contratação.

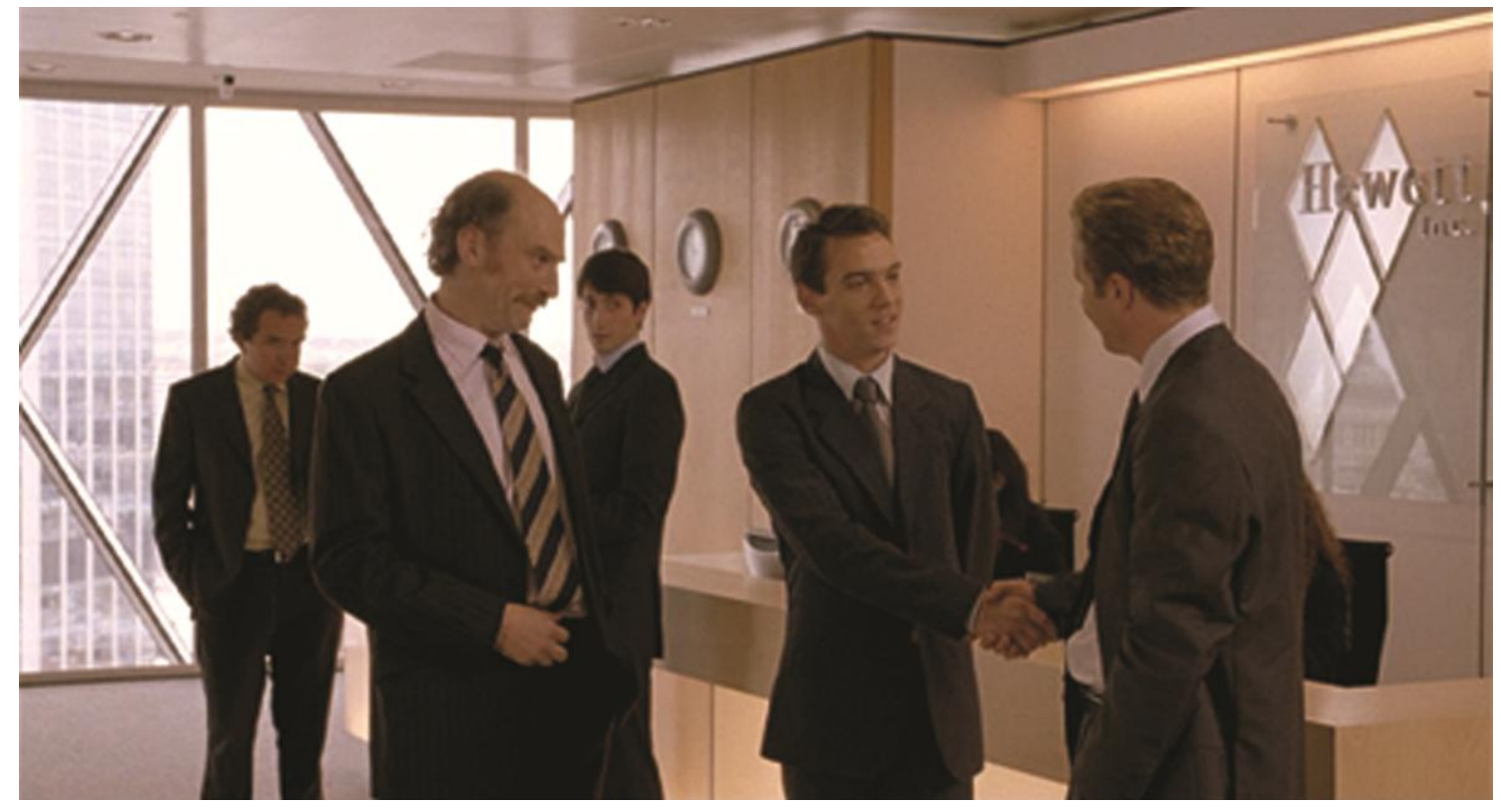

Figura 2: Parte interna do Swiss Re. Contratação de Chris Wilton na Hewett Inco. 


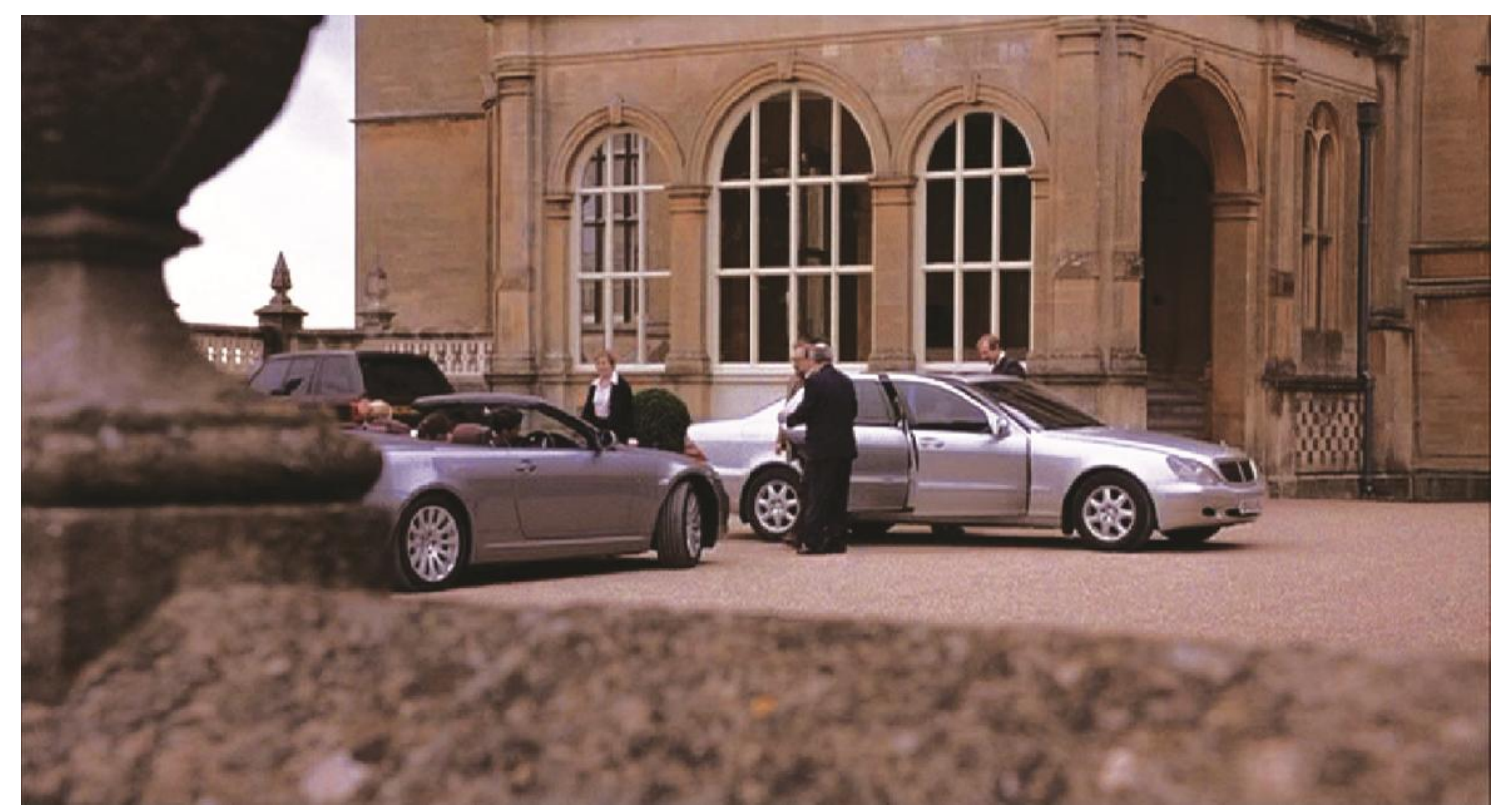

Figura 3: Parte externa do Englefield Estate. Chegada da família Hewett à casa de campo. Empregados da residência aguardam os proprietários.

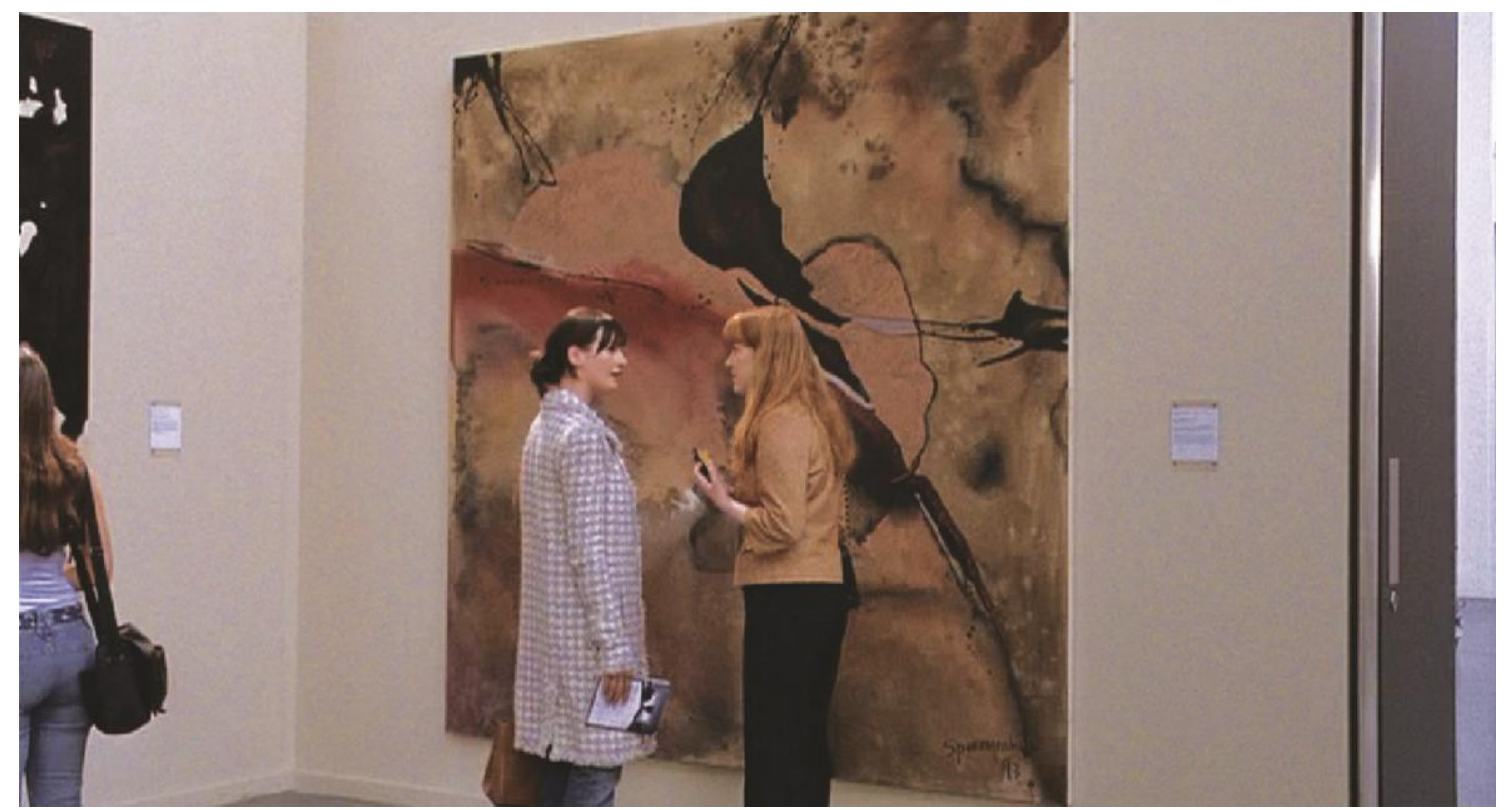

Figura 4: Tate Modern. Autor desconhecido. Chloe e Carol conversam sobre gravidez ao passo que (não) observam as obras de arte. 


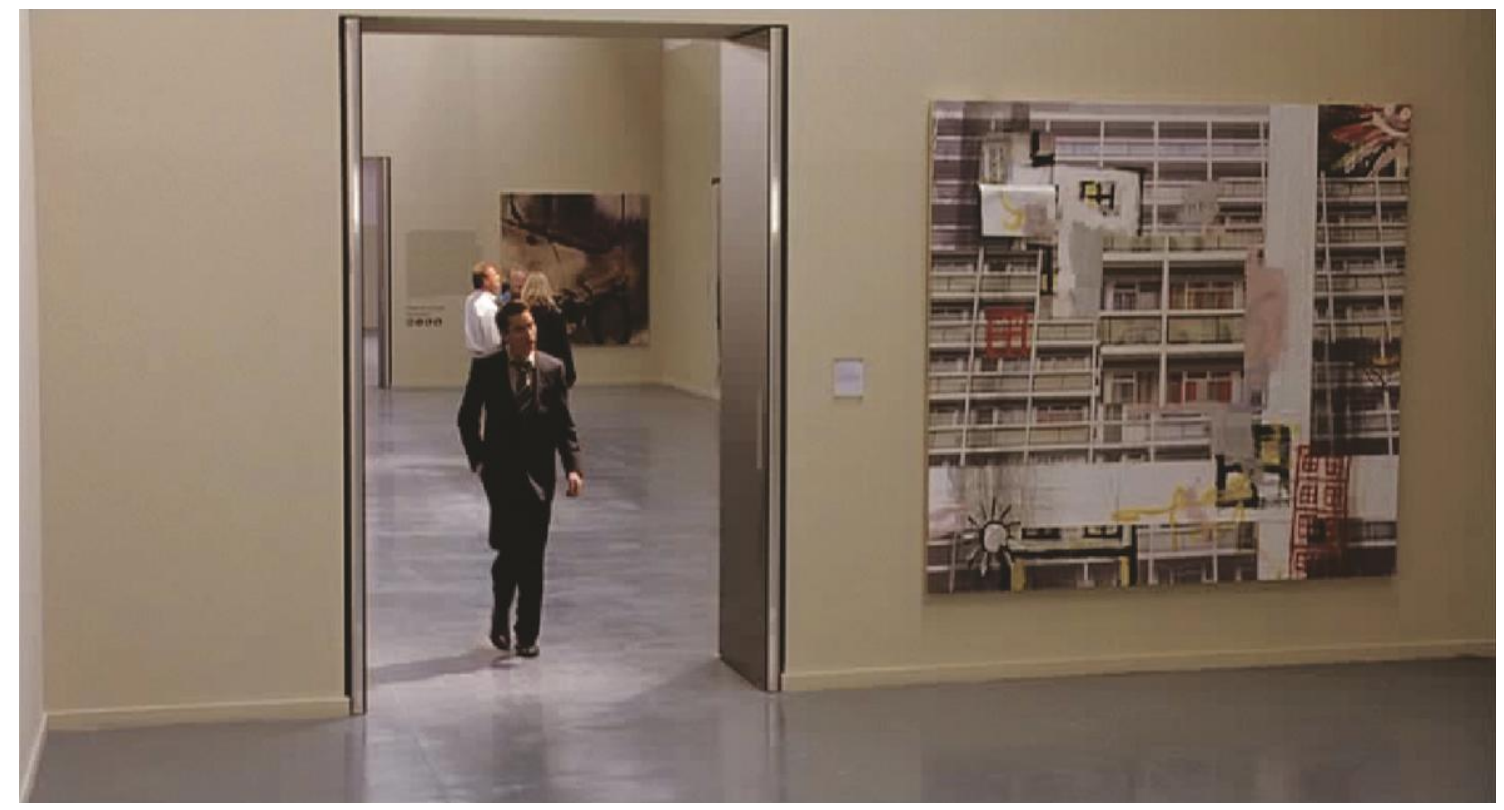

Figura 5: Tate Modern. David Hepher, Albany Flats, 1969/1974. Chris procura por Nola.

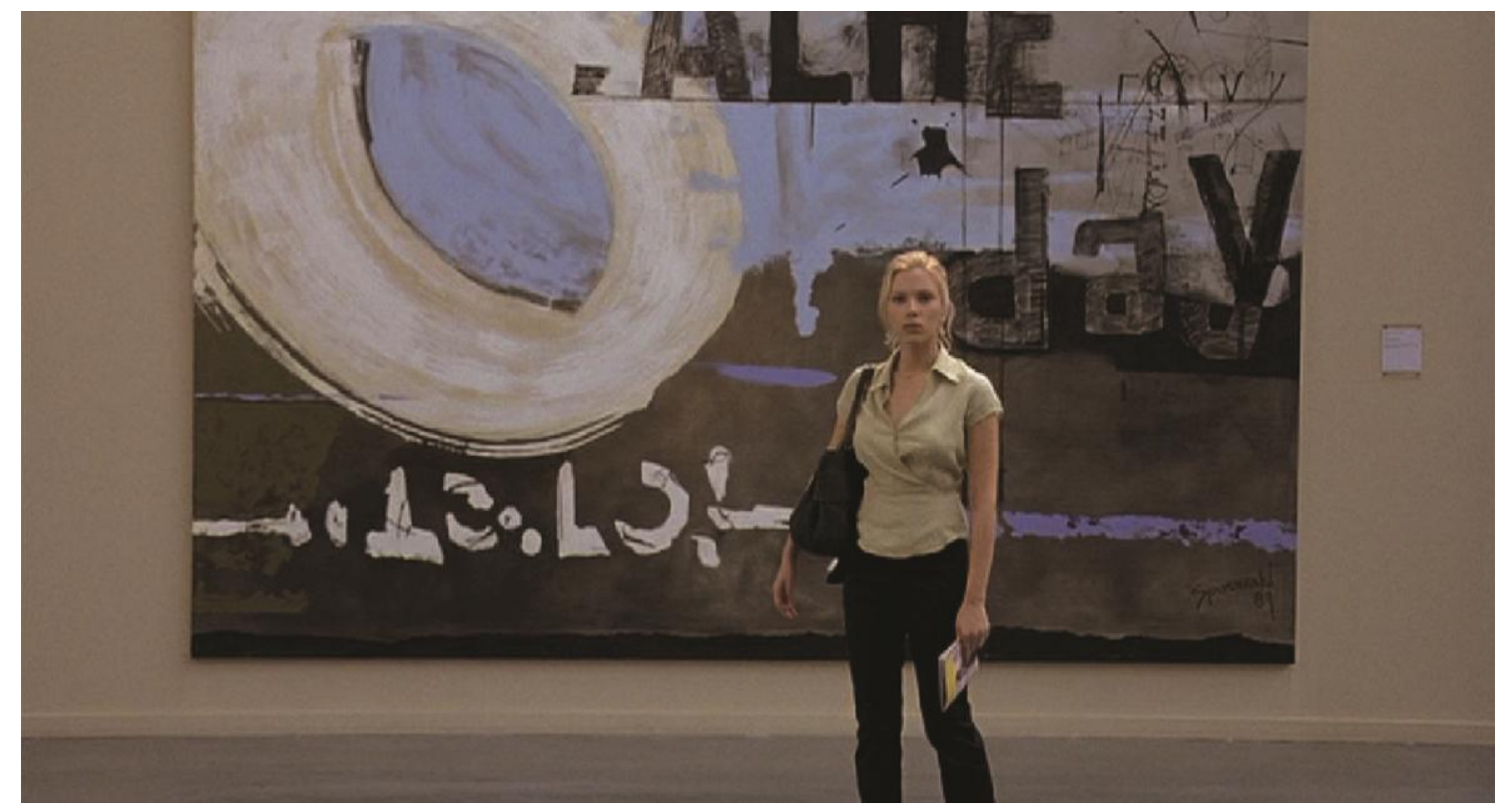

Figura 6: Tate Modern. Autor desconhecido. Nola encontra Chris, pode-se observar a palavra "ache", (em português, dor), escrita no quadro. 


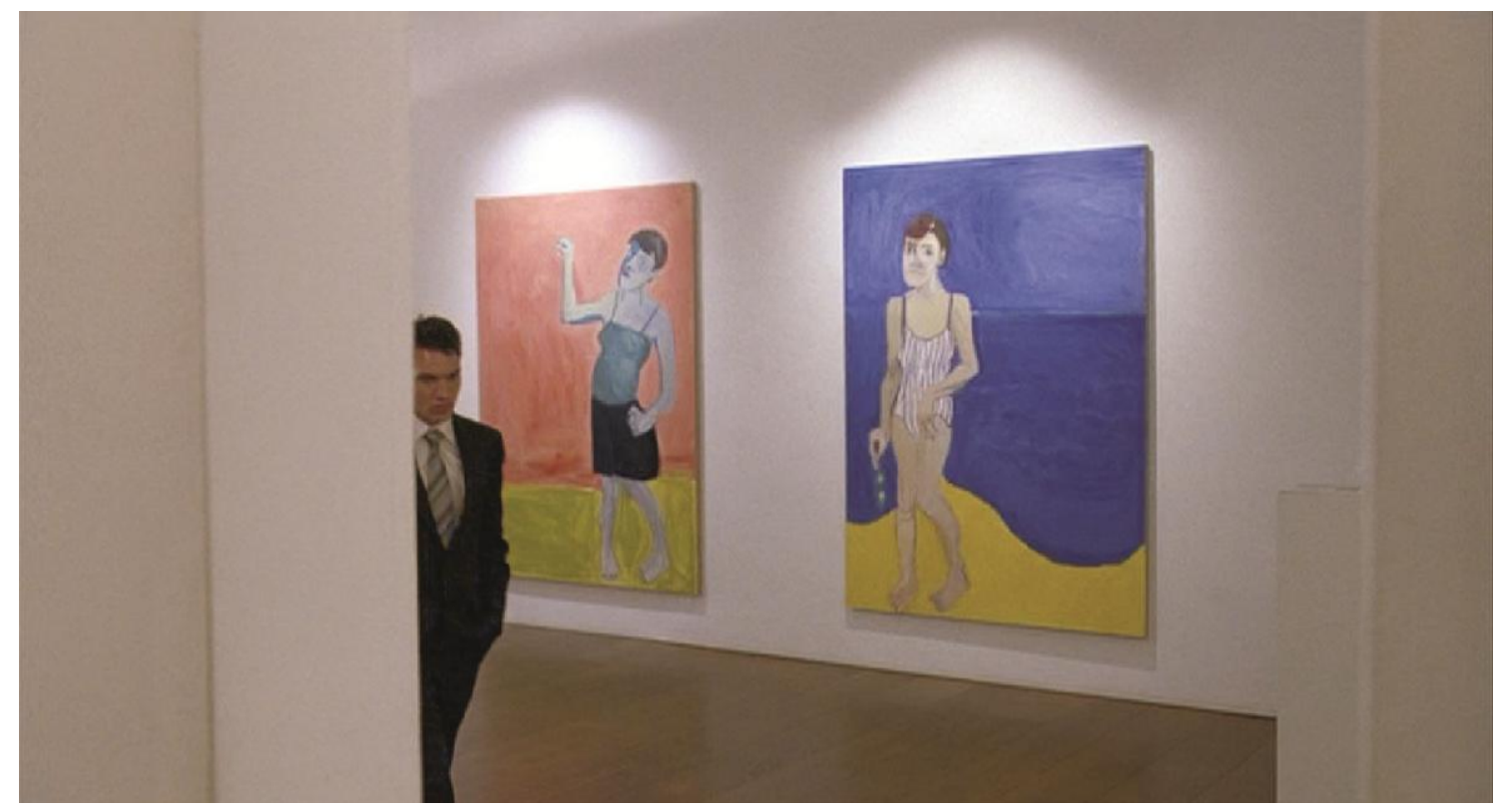

Figura 7: Galeria de Chloe. Lucy Jones, quadros de figuras femininas. Chris encontra a esposa.

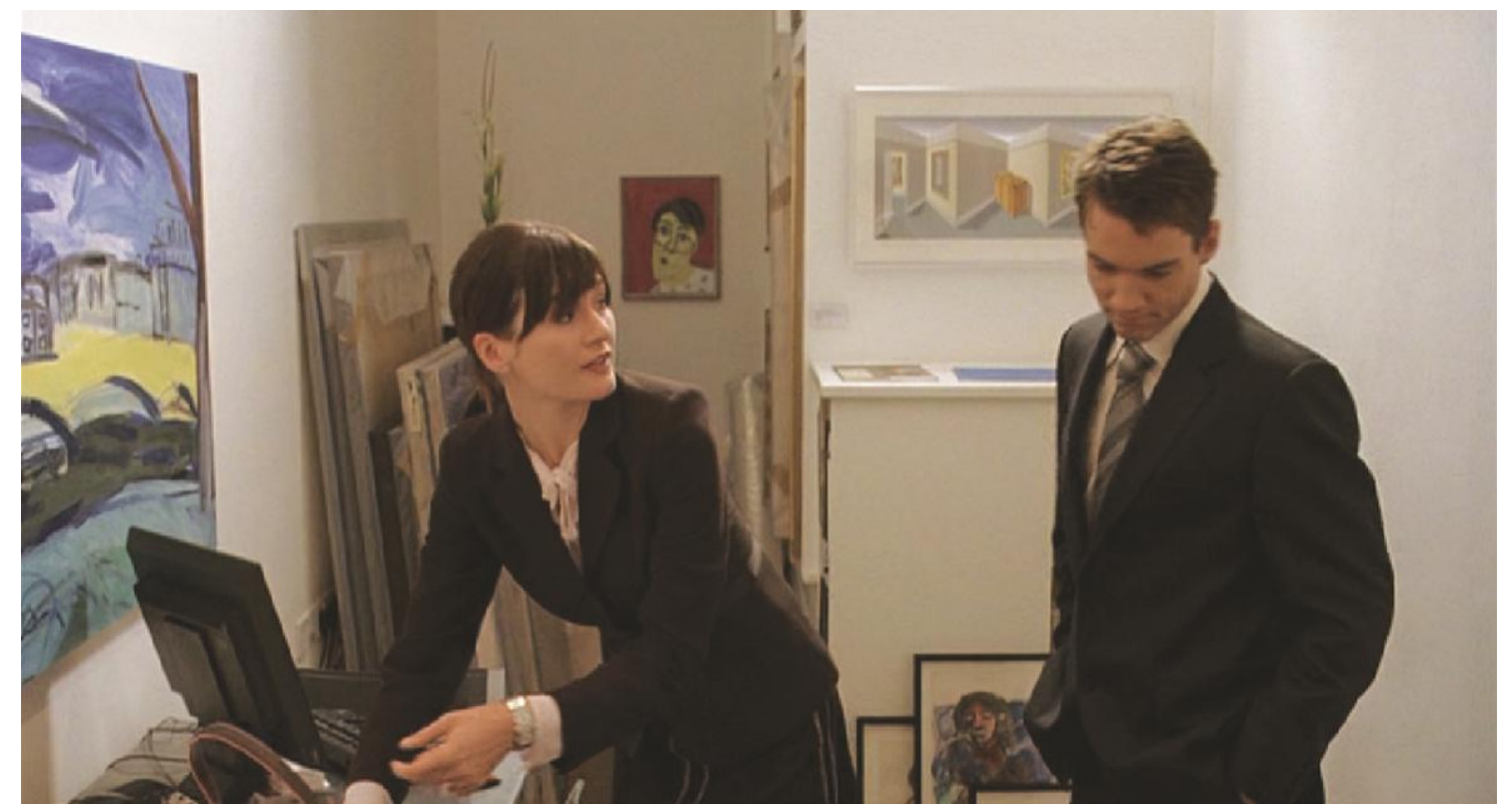

Figura 8: Galeria de Chloe. Lucy Jones, quadros da paisagem londrina que estão na galeria e na residência de Chloe e Chris. 


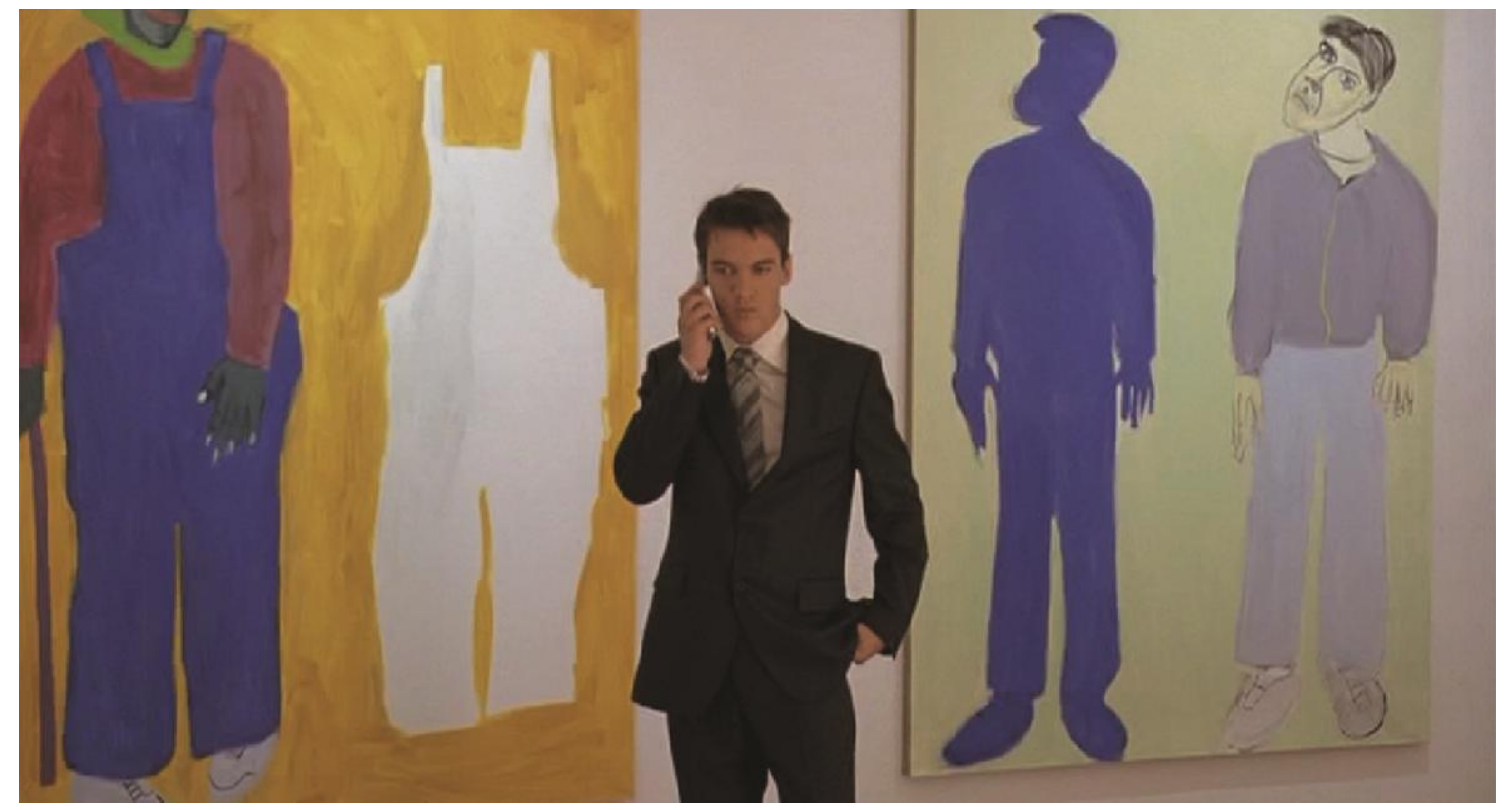

Figura 9: Galeria de Chloe. Lucy Jones, quadros com figuras masculinas. Chris telefona para Nola.

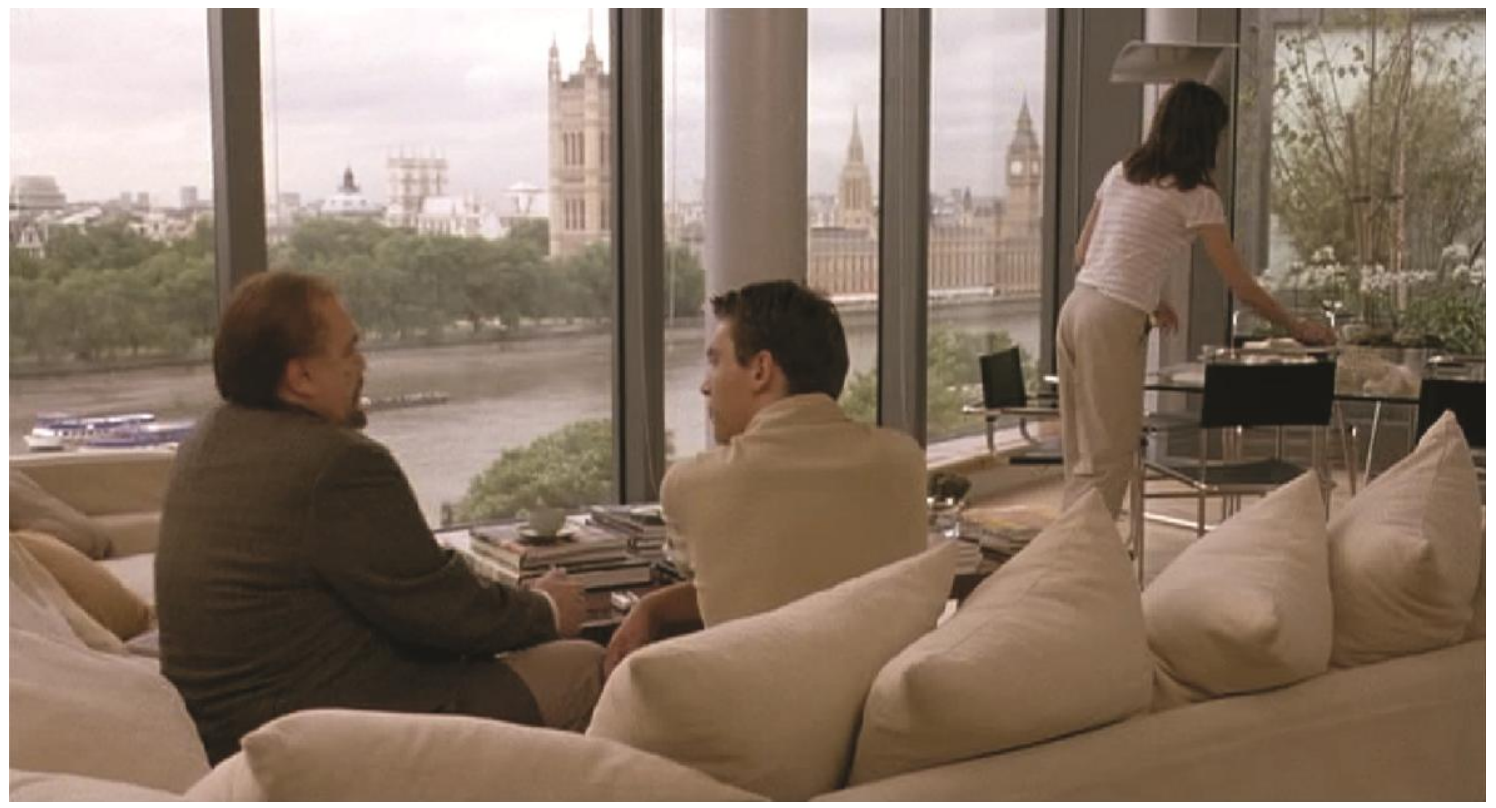

Figura 10: Parliament View Apartments. Vista do rio Tâmisa e do Parlamento inglês a partir de apartamento de Chris e Chloe. Chris conversa com o patriarca. 


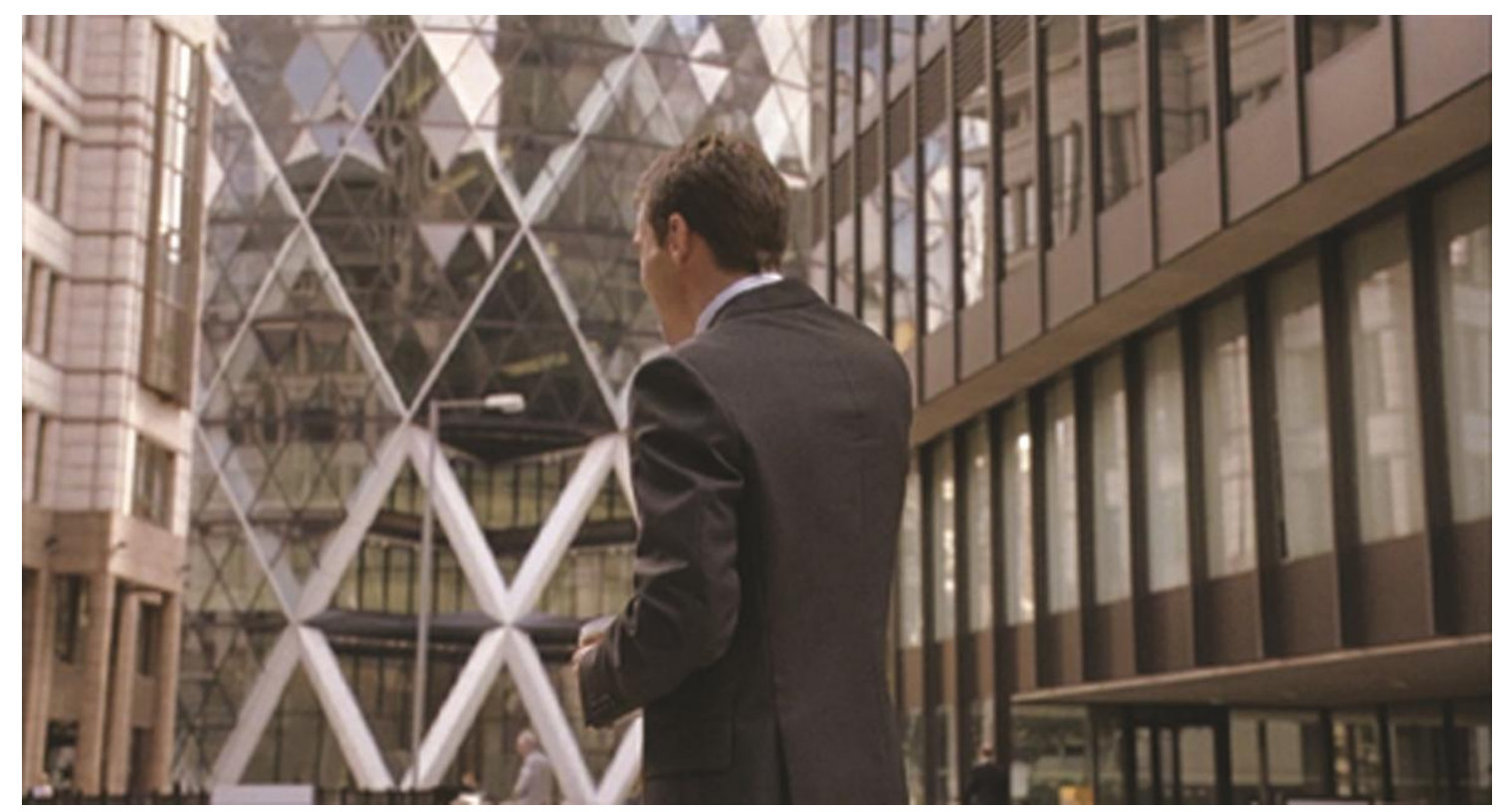

Figura 11: Parte externa do Swiss Re. Momento que antecede o assassinato de Nola

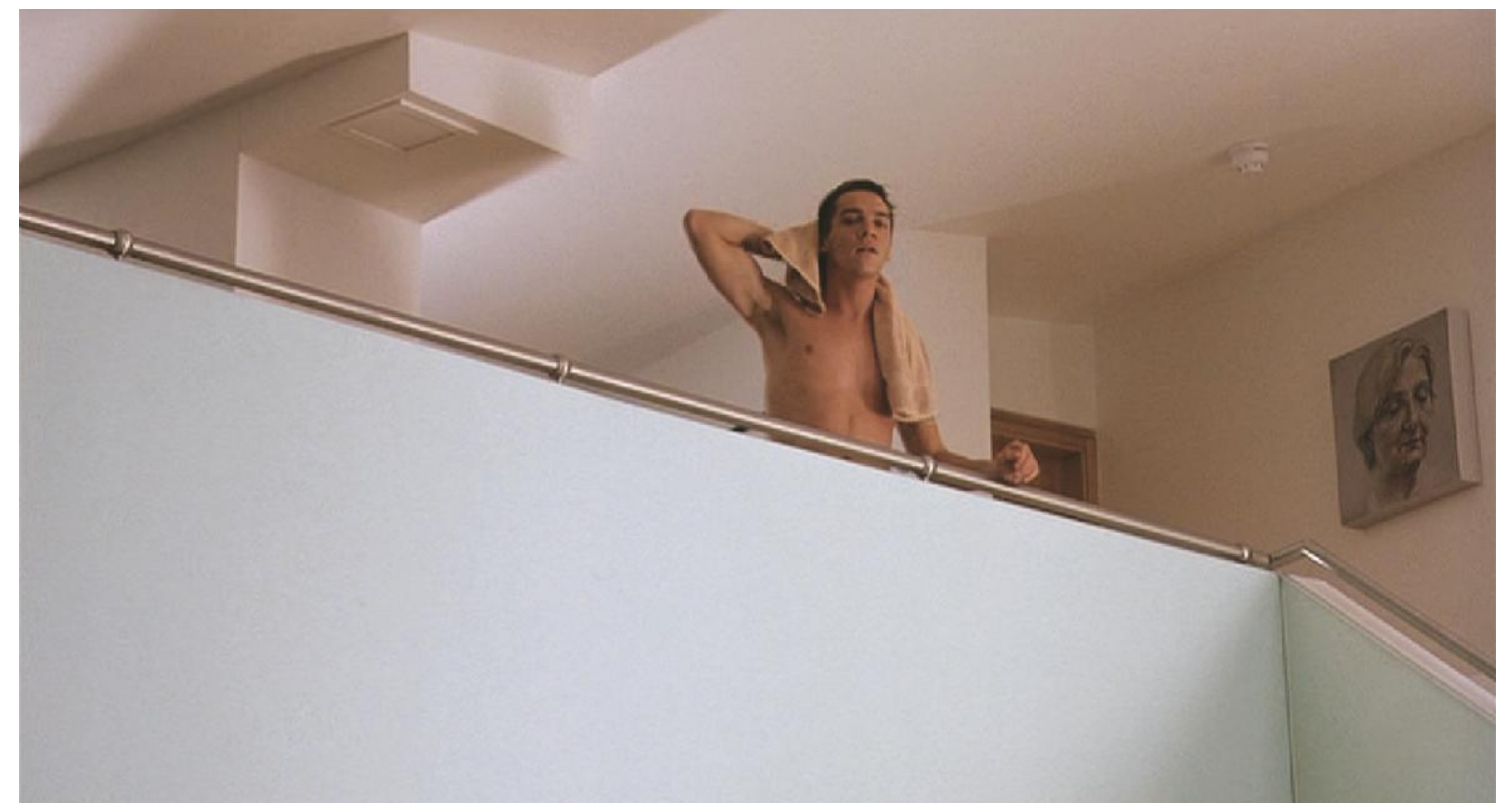

Figura 12: Parte interna do apartamento no edifício Parliament View Apartments. No canto direito da cena, observa-se o quadro de uma senhora, com autoria provável de Lucian Freud . 


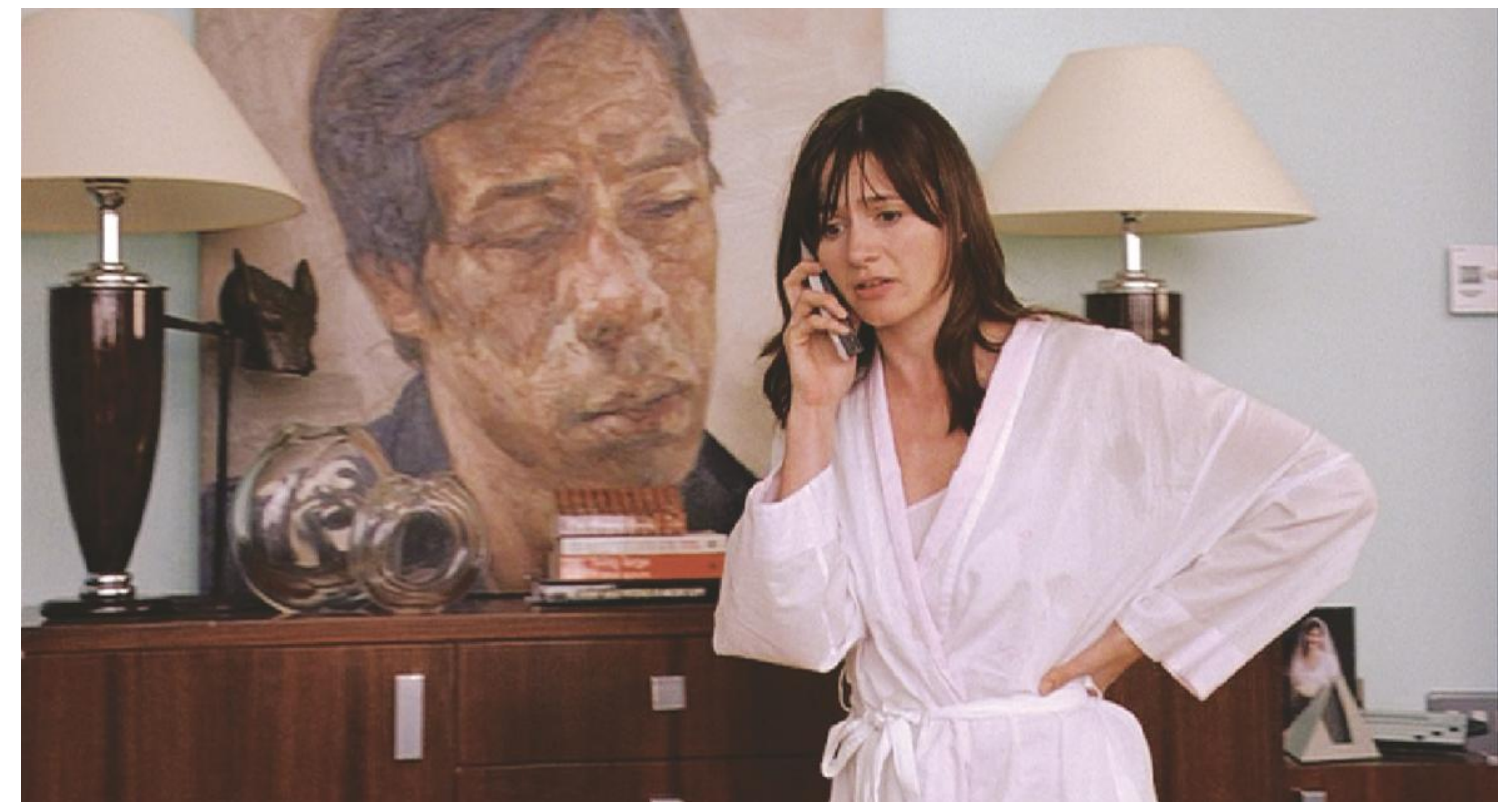

Figura 13: Parte interna do apartamento no edifício Parliament View Apartments. Quadro do homem negro, com autoria provável de Lucian Freud.

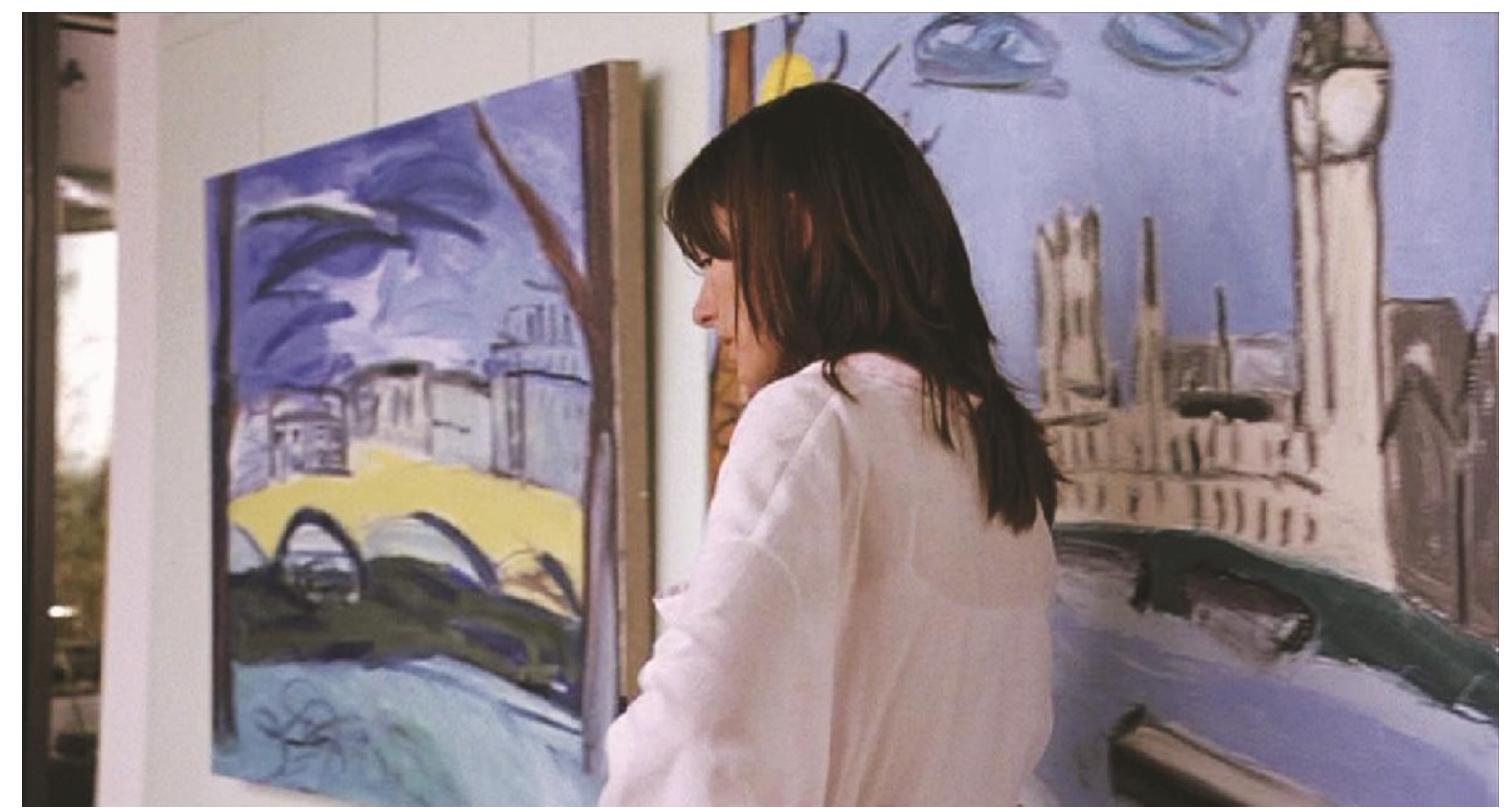

Figura 14: Parte interna do apartamento no edifício Parliament View Apartments. Quadro da paisagem londrina de Lucy Jones presente tanto na galeria de Chloe como no apartamento 


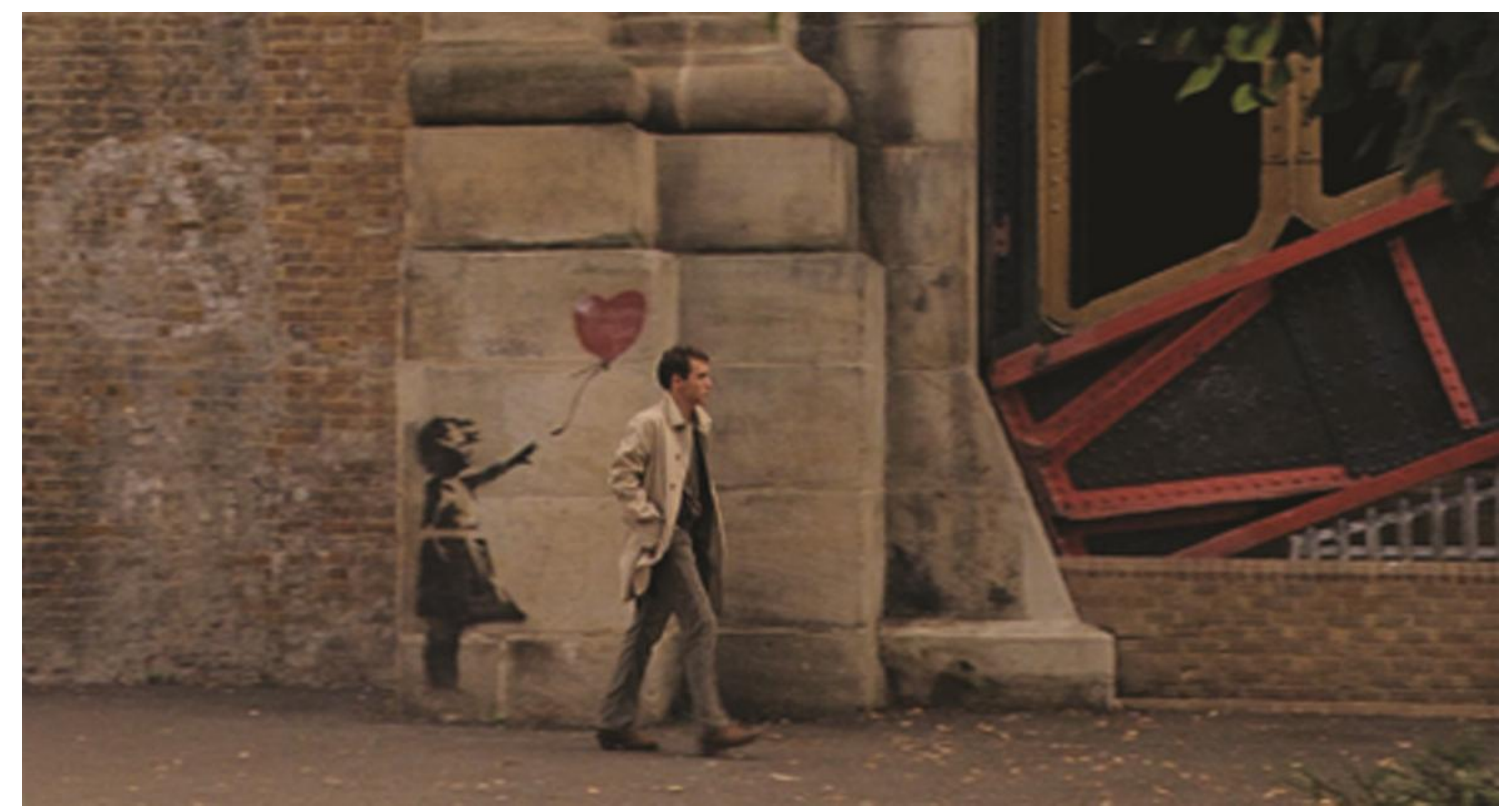

Figura 15: Ponte Queen's Walk. Bansky, grafite de Menina com balão vermelho. Pichação do símbolo anarquista.

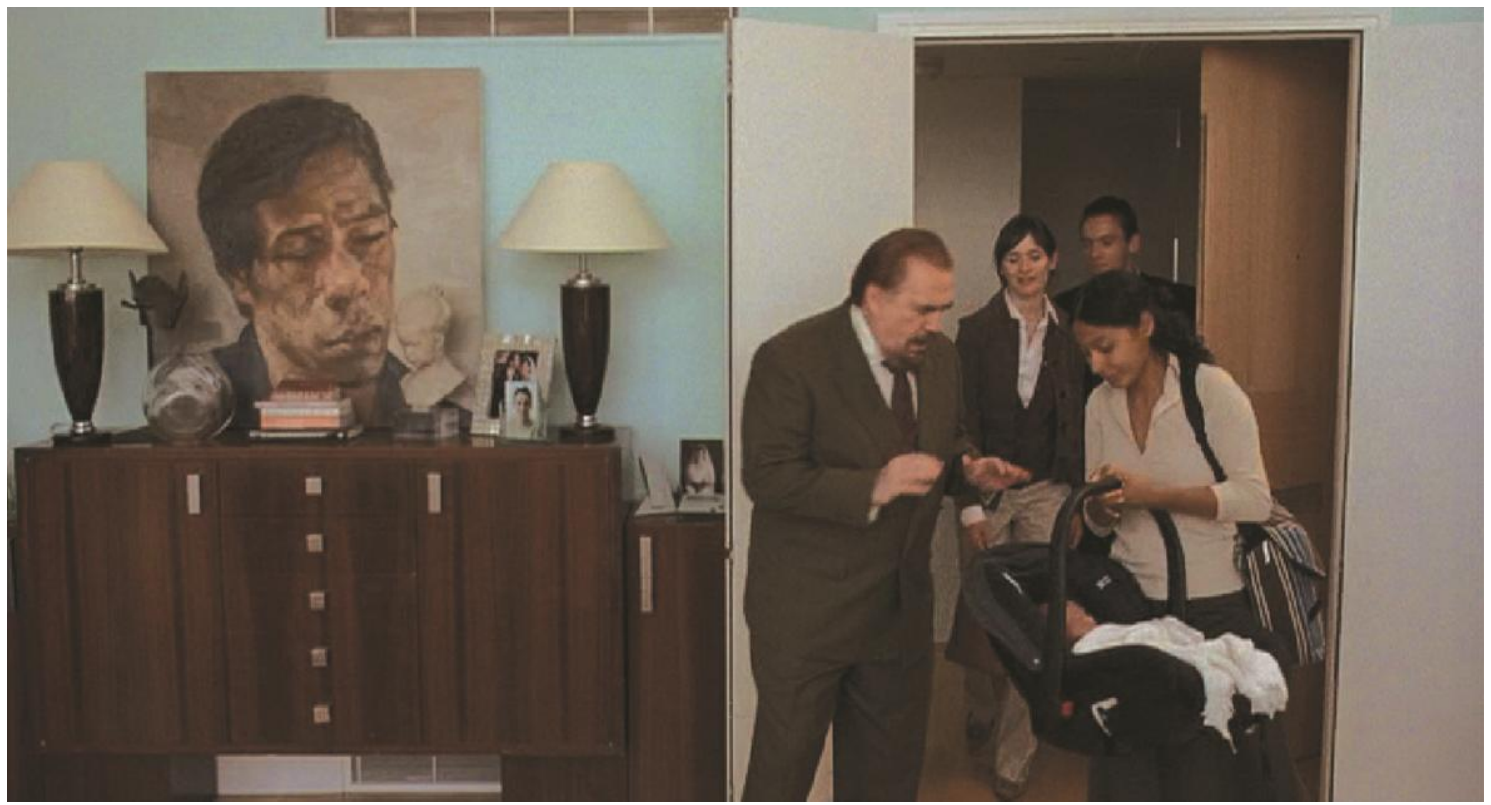

Figura 16: Parliament View Apartments. Ao fundo, quadro de um homem negro, com autoria provável de Lucian Freud e porta-retratos do casal Chloe e Chris. Momento em que se observa a chegada do bebê, conduzido pela babá e o patriarca. 


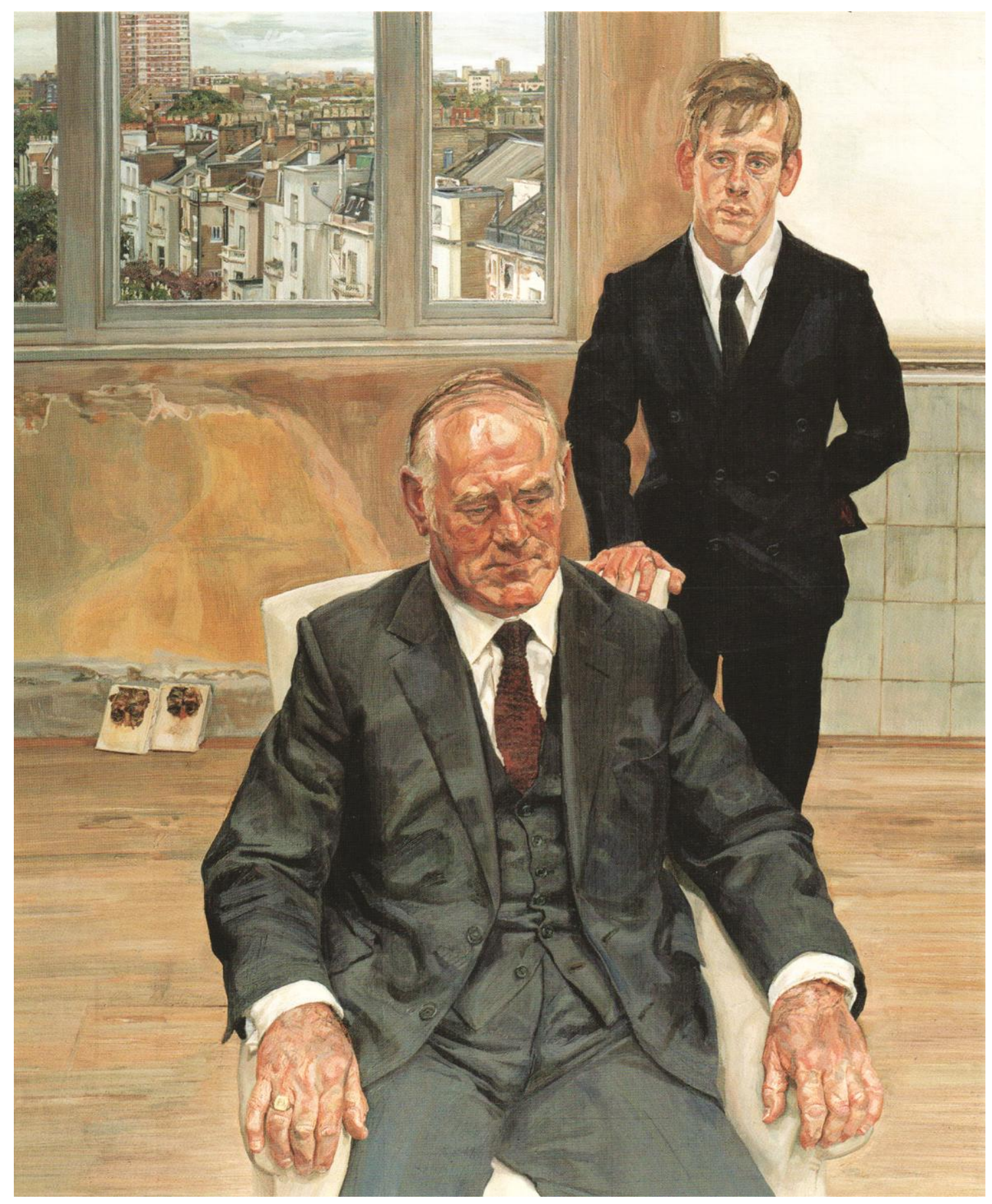

Figura 17: Lucian Freud, Dois irlandeses em W11, 1984/85. 
